\title{
PETROGRAPHIC STUDY OF 50 SAMPLES FROM TERTIARY SANDSTONE OF COOK INLET, ALASKA: POTENTIAL TIGHT GAS RESERVOIRS
}

by

J.J. Hickey, M.D. Wilson, and R.R. Reifenstuhl

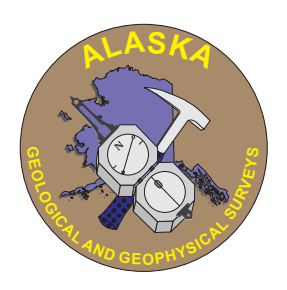

Published by

STATE OF ALASKA

DEPARTMENT OF NATURAL RESOURCES

DIVISION OF GEOLOGICAL \& GEOPHYSICAL SURVEYS 
Report of Investigations 2007-2

\section{PETROGRAPHIC STUDY OF 50 SAMPLES FROM TERTIARY SANDSTONE OF COOK INLET, ALASKA: POTENTIAL TIGHT GAS RESERVOIRS}

by
James J. Hickey, Michael D. Wilson, and Rocky R. Reifenstuhl

2007

This DGGS Report of Investigations is a final report of scientific research. It has received technical review and may be cited as an agency publication. 


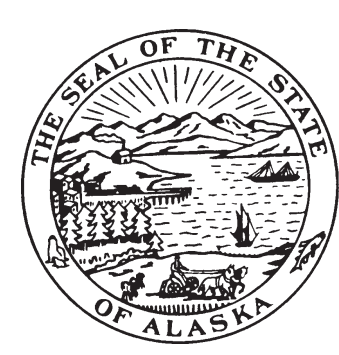

STATE OF ALASKA

Sarah Palin, Governor

DEPARTMENT OF NATURAL RESOURCES

Tom Irwin, Commissioner

\title{
DIVISION OF GEOLOGICAL \& GEOPHYSICAL SURVEYS \\ Robert F. Swenson, State Geologist and Acting Director
}

Division of Geological \& Geophysical Surveys publications can be inspected at the following locations. Address mail orders to the Fairbanks office.

\author{
Alaska Division of Geological \\ \& Geophysical Surveys \\ 3354 College Road \\ Fairbanks, Alaska 99709-3707 \\ Elmer E. Rasmuson Library \\ University of Alaska Fairbanks \\ Fairbanks, Alaska 99775-1005
}

University of Alaska Anchorage Library 3211 Providence Drive Anchorage, Alaska 99508

\author{
Alaska Resource Library \\ and Information Services (ARLIS) \\ 3150 C Street, Suite 100 \\ Anchorage, Alaska 99503
}

\begin{abstract}
Alaska State Library
State Office Building, 8th Floor

333 Willoughby Avenue

Juneau, Alaska 99811-0571
\end{abstract}

This publication released by the Division of Geological \& Geophysical Surveys was produced and printed in Fairbanks, Alaska at a cost of $\$ 7$ per copy. Publication is required by Alaska Statute 41, "to determine the potential of Alaskan land for production of metals, minerals, fuels, and geothermal resources; the location and supplies of groundwater and construction materials; the potential geologic hazards to buildings, roads, bridges, and other installations and structures; and shall conduct such other surveys and investigations as will advance knowledge of the geology of Alaska." 


\section{CONTENTS}

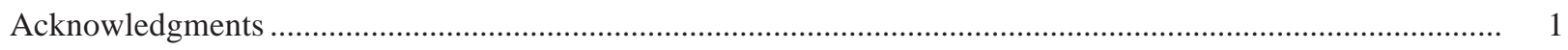

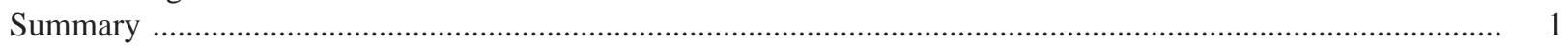

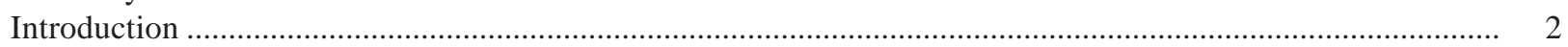

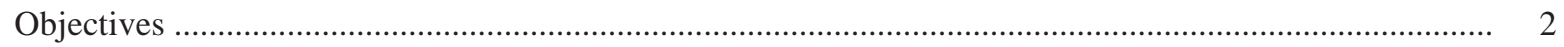

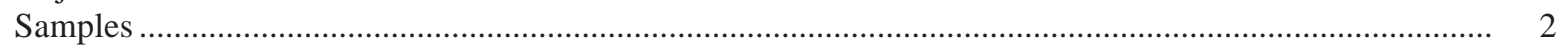

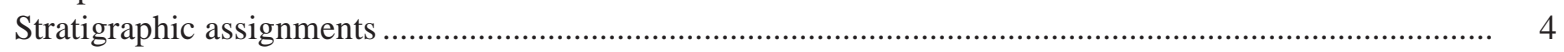

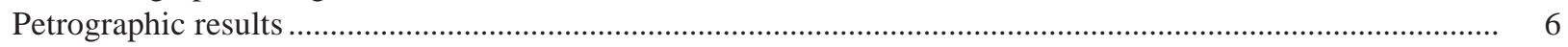

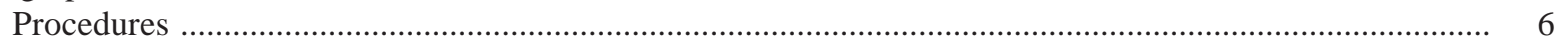

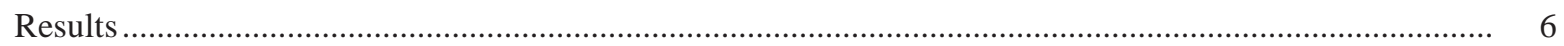

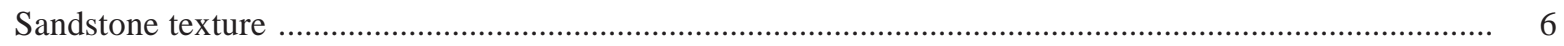

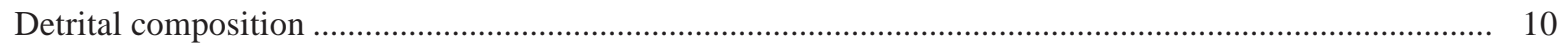

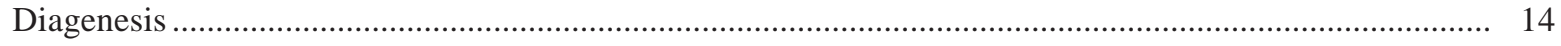

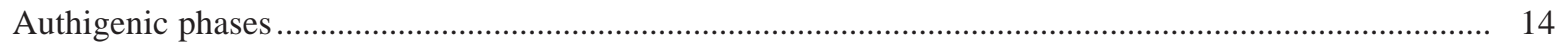

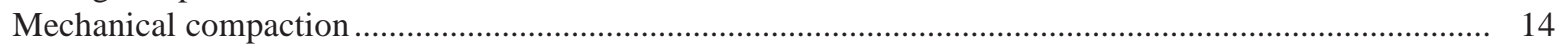

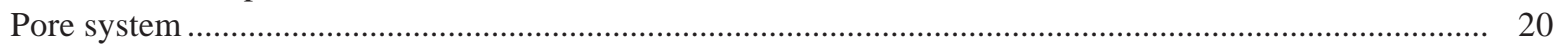

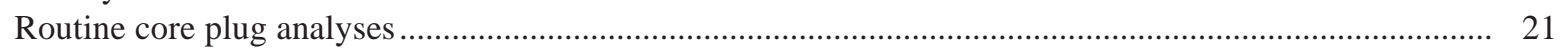

Mercury injection capillary pressure measurements ................................................................................ 24

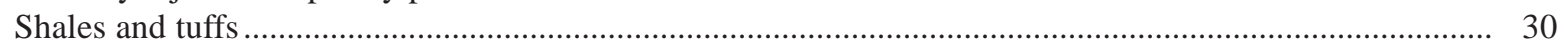

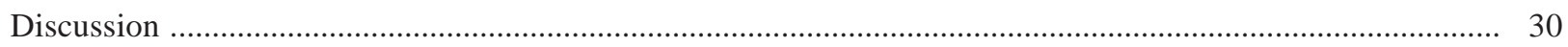

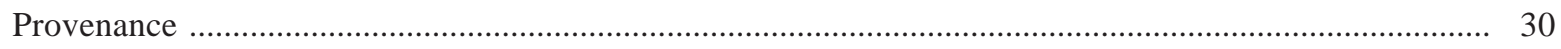

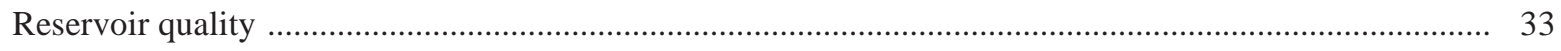

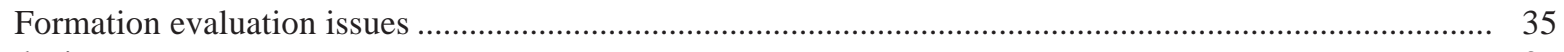

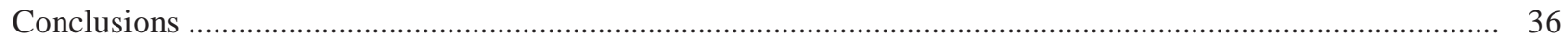

Recommendations for further study ……........................................................................................... 37

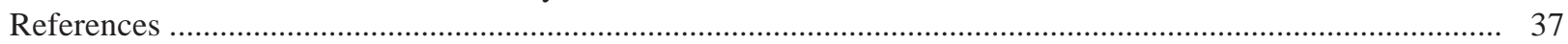

\section{TABLES}

Table 1. List of core samples used in this study, by well, depth range, and nominal depth ............................ 3

2. Inferred stratigraphic assignments of samples selected for point-count analysis ................................. 4

3. Summary of sandstone core analyses and petrographic observations. ................................................ 7

4. Summary of point-count grain size measurements, Cook Inlet sandstones. ........................................ 8

5. Grain-size statistics for sandstones with similar distribution profiles ................................................ 10

6. Selected ternary percentages for point count samples, Cook Inlet sandstones .................................. 12

7. Major grain types in approximate order of increasing ductility, top to bottom ................................... 17

8. Ternary percentages related to pore system, Cook Inlet sandstones ................................................... 20

9. Predicted average porosity and total flow capacity for two hypothetical sand bodies ......................... 24

10. List of samples used for MICP analyses, with selected petrographic characteristics ........................ 25

11. Comparison of core and MICP estimates of porosity and permeability, and pore throat parameters . 25

12. Contact angle and surface tension values for mercury-air and gas-brine capillary systems ............... 29

13. Estimated entry pressures and water saturations at 400' above free water line ................................. 29

14. Comparison of total and hydrocarbon-filled average pore volume for two model sand bodies ......... 30

15. Summary of core analyses and petrographic observations for non-sandstone samples ...................... 31

16. Additional notes on non-sandstone samples ............................................................................... 32

17. Inferred source terranes for major detrital grain types ...................................................................... 


\section{FIGURES}

Figure 1. Cook Inlet base map, illustrating the locations of samples used in this study ................................. 2

2. Simplified tectonic map of the Cook Inlet Basin (after Ryherd, 2003) ................................................ 4

3. Base map showing location of existing Cook Inlet oil and gasfields .................................................. 5

4. Grain-size distribution histograms for two samples from the Swanson River Field ............................ 9

5. Measured grain-size distributions for all point-count samples .............................................................. 9

6. Overall mean grain size vs. permeability .......................................................................................... 11

7. Selected plane-polarized light photomicrographs illustrating detrital clasts in Cook Inlet sandstones

8. Generalized paragenetic sequence, Cook Inlet Tertiary sandstone ..................................................... 15

9. Selected photomicrographs illustrating diagenetic features of Cook Inlet sandstones ....................... 16

10. Ductile grain content vs. intergranular volume, grouped by current burial depth .............................. 17

11. Intergranular volume (\%IGV) vs. current burial depth for all point-count samples .......................... 17

12. Rigid-ductile-matrix ternary plot of Cook Inlet point-count samples, by age and location .............. 18

13. Ternary plot of undeformed-slightly deformed-extensively deformed ductile grains ...................... 19

14. Ternary plot of undeformed-slightly deformed-extensively deformed mica flakes .......................... 19

15. Macroporosity-mesoporosity-microporosity ternary diagram, grouped by core depth .................... 21

16. Porosity/permeability crossplot for all petrographic samples (except tuffs), by grain size ............... 22

17. Calculated porosity/permeability transforms for very fine and fine to very coarse sandstones ......... 22

18. Linear porosity/depth trends calculated for very fine and fine to very coarse sandstones .................. 23

19. Core porosity vs. current burial depth for all samples of fine sand size and coarser ......................... 23

20. Calculated depth trends for permeability of very fine and fine to very coarse sandstones ................. 23

21. Intergranular volume (percent by volume) vs. horizontal permeability (millidarcies), by amount of cement ..................................................................................................................... 24

22. Mercury/air capillary pressure vs. wetting phase saturation drainage curves ..................................... 26

23. Distribution of calculated pore aperture sizes, Beluga River 1 11,590' and King 1B 13,435.5' ......... 27

24. Distribution of calculated pore aperture sizes, MGS St. 1 5,696' and SRU 1 10,816' ...................... 27

25. Distribution of calculated pore aperture sizes, TBU A-2 6,374.5'and TBU A-7 6,382' ...................... 28

26. Water saturation vs. height above free water level in a gas/water system, based on MICP data ........ 29

27. Total quartz-feldspar-lithics, grouped by estimated stratigraphic age and location .......................... 33

28. Monocrystalline quartz-feldspars-total lithics ternary plot, by age and location ............................... 34

29. Ternary plots of selected detrital components, grouped by stratigraphic age and location ................. 35

\section{APPENDIX}




\title{
PETROGRAPHIC STUDY OF 50 SAMPLES FROM TERTIARY SANDSTONE OF COOK INLET, ALASKA: POTENTIAL TIGHT GAS RESERVOIRS
}

\author{
by \\ James J. Hickey ${ }^{1}$, Michael D. Wilson ${ }^{2}$, and Rocky R. Reifenstuhl ${ }^{3}$
}

\section{ACKNOWLEDGMENTS}

This report was prepared as part of the project titled, "Roadmap for producing Alaska's coalbed and tight sand gas," through the University of Alaska Fairbanks Petroleum Development Laboratory (Dr. David Ogbe). This study was sponsored by the Research Partnership to Secure Energy for America, under subcontract No. R-513, September 2003-2004.

We thank Robert F. Swenson (Denali Geological Services at time of review; currently State Geologist and Acting Director, Alaska Division of Geological \& Geophysical Surveys [DGGS]), Robert Sterling (EOG Resources), and Karen H. Clautice (DGGS, retired) for their reviews of an earlier version of this report. The grain-size and point-count data files were produced by Dr. Michael Wilson (Denver, CO), who performed the point counts. The capillary pressure data files are provided by Mr. George Bolger (PetroTech Associates, Houston, TX), who performed the MICP analyses.

\section{SUMMARY}

Fifty conventional core samples from Tertiary reservoir rocks were examined in thin section as part of a larger effort to characterize the potential for gas production from low-permeability sandstones in Cook Inlet. The core was collected from, and has been returned to, the Division of Geological \& Geophysical Surveys Geologic Material Center, Eagle River, Alaska.

The sandstones and pebbly sandstones in the sample suite represent a wide range of texture, composition, and burial history. These sandstones fall into two main textural groups: very fine-grained and slightly shaly; and fine- to medium-grained or coarser, well-sorted, with little or no clay matrix. Sand composition is dominated by quartz with common feldspars, volcanic rock fragments, low-grade metasedimentary fragments, and mica flakes. Sand provenance includes both dissected volcanic arc (Alaska Range) and accretionary wedge (Chugach terrane); which of the two source areas is dominant varies over time, and to a lesser extent laterally across the basin (particularly in the older part of the section). The relatively lithic-rich and occasionally micaceous nature of most of the sandstones results in a high content of mechanically ductile grains, prone to plastic deformation during burial.

Mechanical compaction dominates the burial diagenetic evolution of these sandstones: the median intergranular volume is about 14 percent, reflecting a median ductile grain content of 25 percent by volume. Authigenic phases are typically minor, consisting mostly of patchy pore-filling calcite or kaolinite; other phases, such as smectite, corrensite, and clinoptilolite, may occur in very volcanogenic samples. Preliminary reconstructions of burial history based on our small sample suite indicate that most of the authigenic phases do not begin to form until the sandstones reach a burial depth of 8,000 ft or more. However, unpublished industry data indicate that locally within this heterogeneous basin diagenesis occurs much shallower, resulting in clay grain coatings (smectite, chlorite, kaolinite). The late arrival and patchy occurrence of pore-filling cements means that they have little impact on the progress of mechanical compaction, but their presence does lead to a modest decrease (up to an order of magnitude) in permeability relative to uncemented sandstones. With ongoing burial and compaction, the sandstone pore system evolves from one dominated by intergranular macropores (with pore diameters on the order of 100 microns and pore apertures around 10 microns) to one characterized by a smaller number of less-well-connected mesopores $(<20$ microns across with micron-scale apertures) and microporosity. Both intergranular microporosity (within kaolinite aggregates and other authigenic clays) and intragranular microporosity (within argillaceous lithic grains, leached feldspars, and altered micas) are a significant proportion of the total porosity in more deeply buried sandstones. The combination of strongly compacted grain frameworks, small intergranular pores, and common microporosity are reflected in relatively adverse capillary properties, with high entry pressures and high

\footnotetext{
${ }^{1}$ Applied Reservoir Petrology, LLC, 7019 Southridge Drive, Dallas, TX 75214

Email: applrespet@msn.com

${ }^{2}$ Geological consultant, 12255 West 17th Avenue, Lakewood, CO 80215

${ }^{3}$ Alaska Division of Geological \& Geophysical Surveys, 3354 College Road, Fairbanks, AK 99709-3707
} 
irreducible water saturations. A typical fine- to mediumgrained sandstone with a maximum burial depth of $9,000 \mathrm{ft}$ would have an average porosity of about 13 percent, an absolute permeability of less than $3 \mathrm{md}$, and an irreducible water saturation of more than 30 percent (at $400 \mathrm{ft}$ above the free water level). Very fine-grained sandstones are compacted to sub-millidarcy permeabilities after less than 3,000 ft of burial, whereas coarser-grained sandstones do not fall below 1 md until they approach depths of 12,000 ft. The primary controls on reservoir quality are maximum burial depth and sand texture; sand composition (in particular, ductile grain content) may have a secondary impact as well, but the available sample population is not large enough to demonstrate such a correlation.

\section{INTRODUCTION}

\section{OBJECTIVES}

There is increasing interest in the potential for natural gas production from low-permeability conventional reservoirs in the Cook Inlet Basin. Such "tight gas sandstones" have been overlooked in the past because of their poor reservoir quality and the limited demand for gas. Declining production from existing fields and technical advances in the detection and fracture stimulation of tight gas reservoirs have improved the prospects for economic development. This report is a summary of an investigation into the controls on reservoir quality of the sandstones that would make up tight gas reservoirs in Cook Inlet. The objectives of this study are to document the composition and burial diagenesis of a range of res- ervoir sandstones, and to interpret the observed sandstone properties in terms of basin-scale controls on reservoir quality (porosity, permeability, capillarity). An understanding of these controls may then be integrated with models of sand depositional facies and basin history (Magoon and Claypool, 1981; Magoon, 1994) to provide critical tools for the exploration for tight gas sandstone reservoirs in the Cook Inlet Basin.

\section{SAMPLES}

Fifty samples from archived conventional cores, from 25 wells in the Cook Inlet area, were collected from the Geologic Materials Center in Eagle River (table 1). In many cases only a depth range is specified to identify the available core pieces; in such cases, for the purposes of this study, the mid-point of the depth range has been used as the nominal current burial depth. All depths used in this report are core measured depths, which can differ (in some cases significantly) from the corresponding positions as recorded on wireline logs. Locations of the wells sampled for this study are illustrated in figure 1. The tectonic setting for the Cook Inlet Basin is presented in figure 2, and the location of existing oil and gas fields illustrated in figure 3. An important step in understanding how best to extrapolate the findings of this study will be to place the samples in the context of core descriptions and wireline log response (after proper depth shifting), where available. Rapid vertical and lateral facies changes are typical on non-marine basins such as the Cook Inlet Tertiary, and it is important to establish how representative even a large number of samples may

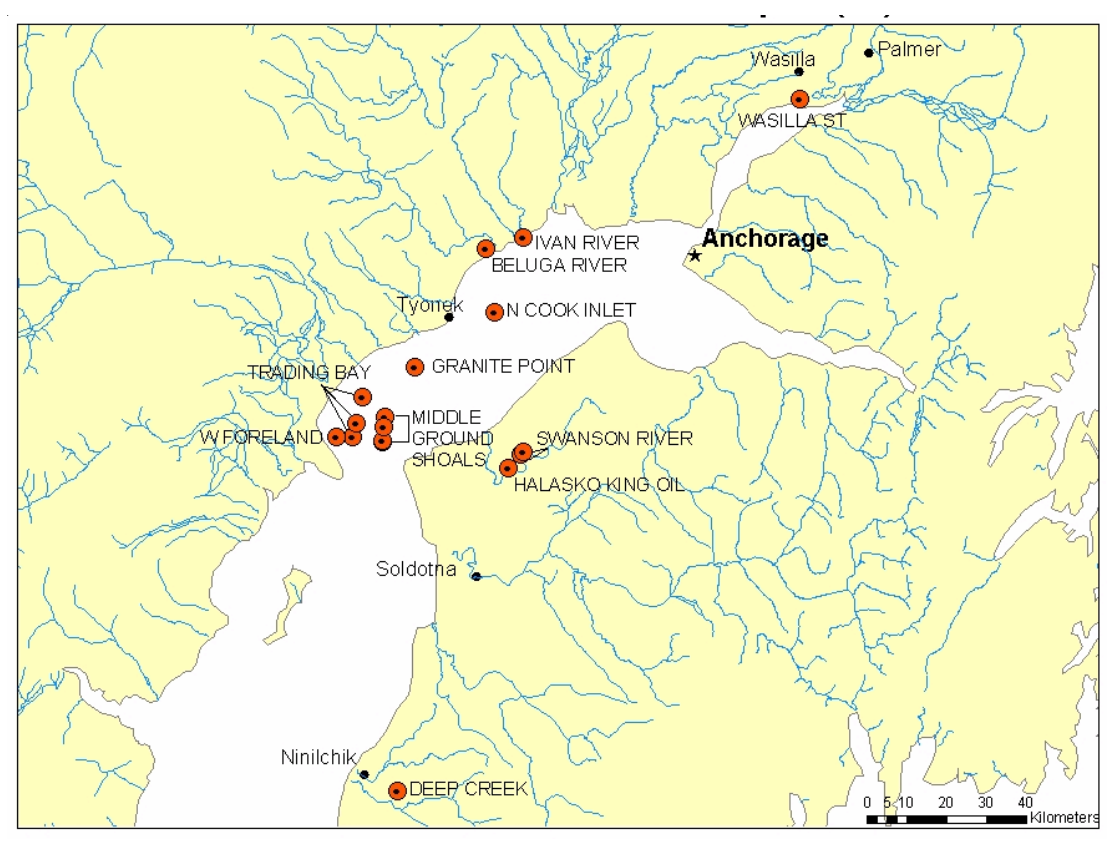

Figure 1. Cook Inlet base map, illustrating the locations of samples used in this study. 
Table 1. List of core samples used in this study, by well, depth range, and nominal depth

\begin{tabular}{|c|c|c|c|c|}
\hline Well & Operator & API & Sample & Depth \\
\hline Beaver Creek Unit 9 & Marathon & 50-133-20445 & $8,085^{\prime}-8,086^{\prime}$ & $8,085.5$ \\
\hline Beaver Creek Unit 9 & Marathon & 50-133-20445 & 7,992' - 7,993' & $7,992.5$ \\
\hline Beluga River 1 & SoCal & 50-283-10027 & $11,581^{\prime}-11,599^{\prime}$ & 11,590 \\
\hline Deep Creek Unit 1 & SoCal & 50-133-10004 & $3,050^{\prime}$ & 3,050 \\
\hline Deep Creek Unit 1 & SoCal & 50-133-10004 & $6,100^{\prime}$ & 6,100 \\
\hline Deep Creek Unit 1 & SoCal & 50-133-10004 & $10,244^{\prime}$ & 10,244 \\
\hline Dolly Varden D-2 & Marathon & 50-733-20069 & $11,722.1^{\prime}$ & $11,722.1$ \\
\hline Dolly Varden D-2 & Marathon & 50-733-20069 & 12,199 & 12,199 \\
\hline Granite Point 1 & Mobil & 50-733-10059 & 8,797’5" - 8,799’10" & 8,798.2 \\
\hline Granite Point 1 & Mobil & 50-733-10059 & 9,252' - 9,254' & 9,253 \\
\hline Granite Point 1 & Mobil & 50-733-10059 & $9,459^{\prime}-9,475^{\prime}$ & 9,467 \\
\hline Granite Point 1 & Mobil & 50-733-10059 & $10,866^{\prime}-10,876^{\prime}$ & 10,871 \\
\hline Granite Point 1 & Mobil & 50-733-10059 & 11,246' - 11,248.5' & $11,247.2$ \\
\hline Halasko King 1-B & Halbouty & 50-133-10116 & 13,368' - 13,369' & $13,368.5$ \\
\hline Halasko King 1-B & Halbouty & 50-133-10116 & $13,435^{\prime}-13,436^{\prime}$ & $13,435.5$ \\
\hline Ivan River 44-1 & Chevron & $50-283-10008$ & $10,814^{\prime}-10,817^{\prime}$ & $10,815.5$ \\
\hline Middle Ground Shoal A33-11 & Shell & $50-733-20383$ & $8,606^{\prime}-8,609^{\prime}$ & $8,607.5$ \\
\hline Middle Ground Shoal A33-11 & Shell & $50-733-20383$ & 7,977' - 7,978.2' & $7,977.6$ \\
\hline Middle Ground Shoal State 1 & Shell & 50-733-10077 & $5,695^{\prime}-5,697$ & 5,696 \\
\hline Middle Ground Shoal State 9 & Amoco & $50-733-10076$ & $9,614^{\prime}-9,615^{\prime}$ & $9,614.5$ \\
\hline N. Cook Inlet A-2 & Phillips & 50-883-20018 & 4,465 & 4,465 \\
\hline N. Cook Inlet A-2 & Phillips & $50-883-20018$ & $4,580^{\prime}$ & 4,580 \\
\hline N. Cook Inlet A-2 & Phillips & 50-883-20018 & $4,815^{\prime}$ & 4,815 \\
\hline Cherryville A-15 (N. Cook Inlet A-15) & Phillips & $50-883-20032$ & 11,142 & 11,142 \\
\hline Soldotna Creek Unit 12-4 & Union & $50-133-10123$ & $10,252^{\prime}$ & 10,252 \\
\hline Soldotna Creek Unit 32-22 & Union & 50-133-10150 & $10,985^{\prime}$ & 10,985 \\
\hline Swanson River Unit 1 & Richfield & $50-133-10136$ & $7,782^{\prime}$ & 7,782 \\
\hline Swanson River Unit 1 & Richfield & 50-133-10136 & $9,230^{\prime}$ & 9,230 \\
\hline Swanson River Unit 1 & Richfield & 50-133-10136 & $8,755^{\prime}$ & 8,755 \\
\hline Swanson River Unit 1 & Richfield & 50-133-10136 & $10,816^{\prime}$ & 10,816 \\
\hline Swanson River Unit 1 & Richfield & 50-133-10136 & $4,185^{\prime}$ & 4,185 \\
\hline Swanson River Unit 2 & Richfield & 50-133-10156 & $10,875^{\prime}$ & 10,875 \\
\hline Swanson River Unit 2 & Richfield & 50-133-10156 & 4,363' & 4,363 \\
\hline Trading Bay Unit 4 & Mobil & 50-733-20001 & 3,105 & 3,105 \\
\hline Trading Bay Unit 4 & Mobil & $50-733-20001$ & $2,346^{\prime}-2,347^{\prime}$ & $2,346.5$ \\
\hline Trading Bay Unit A-2 (State Unit A-02) & Unocal & $50-733-10056$ & $5,990^{\prime}-5,991^{\prime}$ & $5,990.5$ \\
\hline Trading Bay Unit A-2 (State Unit A-02) & Unocal & $50-733-10056$ & $6,374^{\prime}-6,375^{\prime}$ & $6,374.5$ \\
\hline Trading Bay Unit A-7 (State Unit A-07) & Unocal & 50-733-20036 & $6,382^{\prime}$ & 6,382 \\
\hline Trading Bay Unit A-7 (State Unit A-07) & Unocal & $50-733-20036$ & $4,861^{\prime}$ & 4,861 \\
\hline Trading Bay Unit A-7 (State Unit A-07) & Unocal & 50-733-20036 & $3,850^{\prime}-3,851^{\prime}$ & $3,850.5$ \\
\hline Trading Bay Unit D-43 & Mobil & $50-733-20373$ & 10,795 & 10,795 \\
\hline Trading Bay Unit D-43 & Mobil & $50-733-20373$ & 10,566 & 10,566 \\
\hline Trading Bay Unit G-4 & Union & $50-733-20050$ & 9,608 & 9,608 \\
\hline Trading Bay Unit G-4 & Union & $50-733-20050$ & $10,104^{\prime}$ & 10,104 \\
\hline Wasilla State 1 & Pan Am & 50-009-10012 & $2,920^{\prime}-3,000^{\prime}$ & 2,960 \\
\hline Wasilla State 1 & Pan Am & $-009-10012$ & $3,000^{\prime}$ & 3,000 \\
\hline Wasilla State 1 & Pan Am & 50-009-10012 & $4,140^{\prime}$ & 4,140 \\
\hline Wasilla State 1 & Pan Am & 50-009-10012 & $4,848^{\prime}$ & 4,848 \\
\hline West Foreland Unit 1 & Pan Am & 50-133-10028 & $6,220^{\prime}-6,230^{\prime}$ & 6,225 \\
\hline
\end{tabular}

Note: Conventional core samples from the State of Alaska, Division of Geological \& Geophysical Surveys Geologic Materials Center (Eagle River) were used for this study. In a number of cases, only a depth range is available to identify the origin of a particular piece of core material; in such cases, the midpoint of the range has been used as the nominal depth for the sample. 
be, and which mix of sample types should be expected in a given facies setting.

Sample locations have been informally grouped into three main geographic areas (fig. 1): northern inlet (Ivan River, Beluga River, North Cook Inlet), central inlet (Trading Bay, Granite Point, Middle Ground Shoal, West Foreland, West McArthur), and eastern onshore (Swanson River, Soldotna Creek, Beaver Creek, Halasko King 1B, Deep Creek), plus a far northern outlier (Wasilla State).

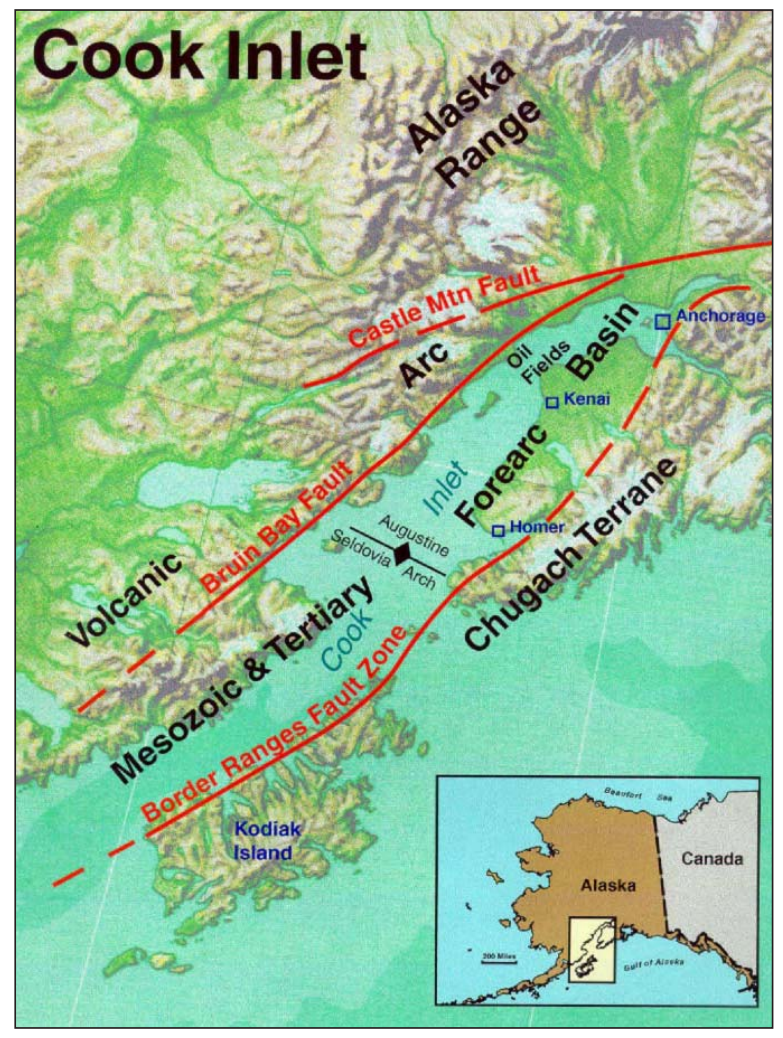

Figure 2. Simplified tectonic map of the Cook Inlet Basin (after Ryherd, 2003).

\section{STRATIGRAPHIC ASSIGNMENTS}

Establishing a chronostratigraphic framework in a sand-rich non-marine basin such as the Tertiary of Cook Inlet is difficult in the absence of solid biostratigraphic data. The existing stratigraphic nomenclature for the Cook Inlet Basin (Calderwood and Fackler, 1972; Hartmann and others, 1972) is lithostratigraphic in origin; regional correlations have generally been at a very coarse scale. For this study, a broad informal framework has been adopted: from oldest to youngest, the Hemlock (lower Oligocene), Tyonek (Oligo-Miocene), Beluga (upper Miocene), and Sterling (Pliocene) Formations. Biostratigraphic control for the petrographic samples in this study is not currently available. As a practical (and necessarily tentative) substitute, samples from producing fields have been assigned to the appropriate reservoir zones. Provisional interpretations for samples that cannot be assigned directly to a formation have been made based on several factors, including current burial depth relative to nearby samples of known age and compositional similarity to known samples. In areas of significant tectonic uplift, current burial depths may not give a reliable indication of relative ages. This is in part due to many uplift studies remaining confidential. Compositional similarity is equally problematic as a basis for age interpretation. With these caveats, stratigraphic assignments (table 2) have been made for sandstones selected for point-count analysis (for which the best compositional information is available).

Table 2. Inferred stratigraphic assignments of samples selected for point-count analysis

\begin{tabular}{|c|c|c|}
\hline Well & Depth & $\begin{array}{c}\text { Stratigraphic } \\
\text { Unit }\end{array}$ \\
\hline Swanson River 1 & 4,185 & Sterling \\
\hline Swanson River 2 & 4,363 & Sterling \\
\hline N. Cook Inlet A-2 & 4,465 & Sterling \\
\hline N. Cook Inlet A-2 & 4,580 & Sterling? \\
\hline Trading Bay A-7 & 4,861 & Beluga? \\
\hline MGS St. 1 & 5,696 & Tyonek \\
\hline Trading Bay A-2 & $5,990.5$ & Beluga? \\
\hline Deep Creek Unit 1 & 6,100 & Beluga? \\
\hline Trading Bay A-2 & $6,374.5$ & Beluga? \\
\hline Trading Bay A-7 & 6,382 & Beluga? \\
\hline MGS A33-11 & $7,977.6$ & Tyonek \\
\hline Swanson River 1 & 8,755 & Tyonek \\
\hline Swanson River 1 & 9,230 & Tyonek \\
\hline MGS St. 9 & $9,614.5$ & Hemlock \\
\hline Trading Bay G-4 & 10,104 & Hemlock? \\
\hline Deep Creek Unit 1 & 10,244 & Hemlock? \\
\hline Trading Bay D-43 & 10,566 & Hemlock? \\
\hline Swanson River 1 & 10,816 & Tyonek? \\
\hline Granite Pt. 1 & 10,871 & Tyonek \\
\hline Swanson River 2 & 10,875 & Tyonek? \\
\hline Cherryville A-15 & 11,142 & Hemlock? \\
\hline Beluga River 1 & 11,590 & Hemlock? \\
\hline Dolly Varden D-2 & $11,722.1$ & Hemlock? \\
\hline Dolly Varden D-2 & 12,199 & Hemlock? \\
\hline Halasko King 1-B & $13,435.5$ & Tyonek? \\
\hline
\end{tabular}

Note: Formation picks that include a question mark (for example, Tyonek?) are based on more indirect or tentative criteria. 


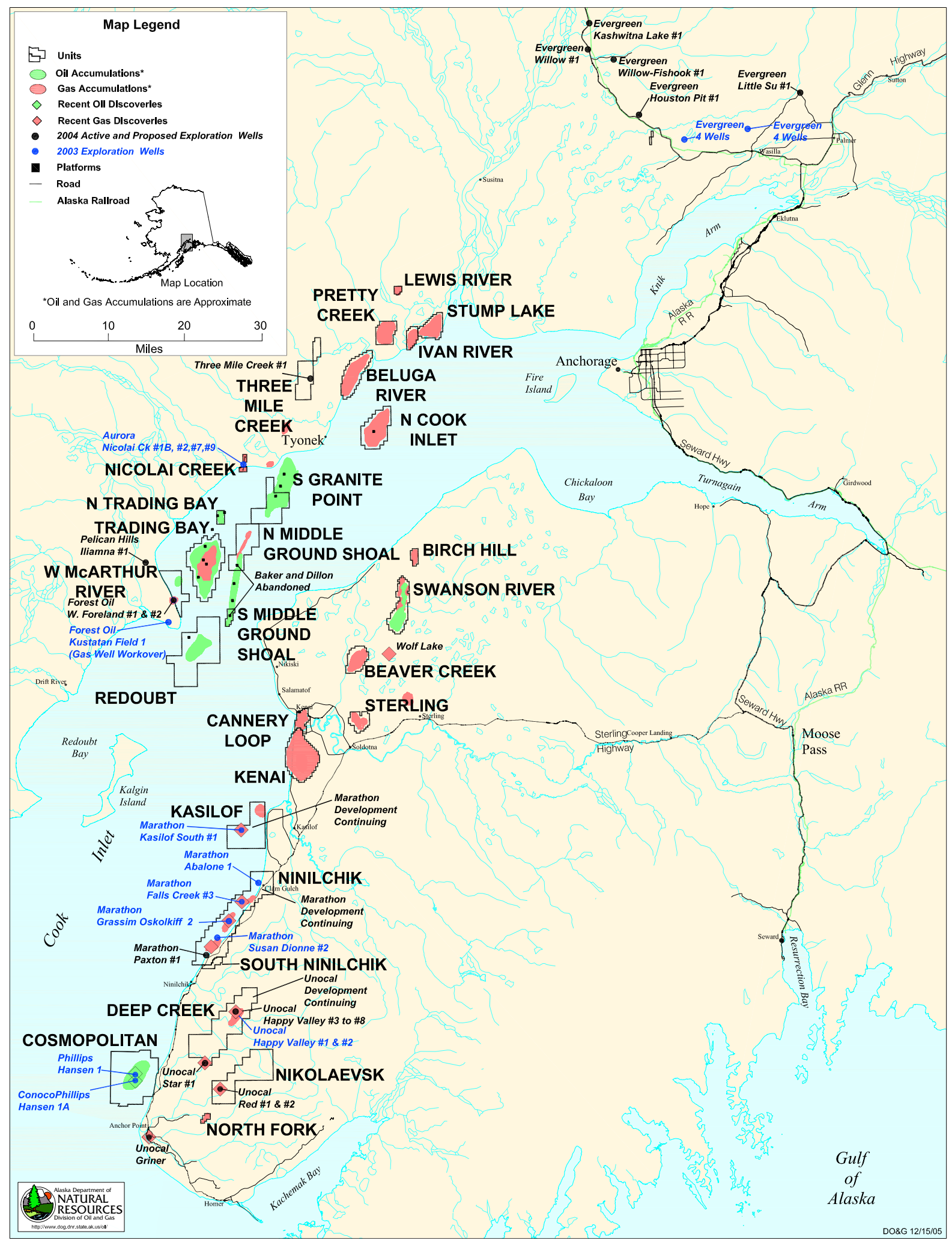

Figure 3. Base map showing location of existing Cook Inlet oil (green) and gas (red) fields. Samples for this study were collected from wells in three broad areas: in the north, Ivan River, Beluga River, and North Cook Inlet; in the west-central part of the inlet, Trading Bay, Middle Ground Shoal, West McArthur River, and Granite Point; and Swanson River, Soldotna Creek, Beaver Creek, and Deep Creek in the eastern onshore area. Note that the northern area is currently dominated by gas production, the central area by oil. (Modified from Ryherd, 2003) 


\section{PETROGRAPHIC RESULTS}

\section{PROCEDURES}

Standard thin sections were prepared from each of the 50 core chips and plugs selected for inclusion in this study. The samples were impregnated with blue-dyed epoxy to highlight porosity, and stained for potassiumbearing minerals. These thin sections have been described qualitatively in terms of texture, composition, diagenesis, and pore structure. A selected group of samples (25) were then further analyzed quantitatively via point counts (300 counts per sample) and grain size measurements (200 long-axis measurements per sample). Selection criteria for the point-count samples included: broad geographic and stratigraphic coverage; low amounts of clay matrix and cement (true of most of the sandstone samples in any case); representative range of porosity and permeability, skewed towards the low-permeability side; wide range of sand grain sizes; "trend groups" of samples from the same location but different depths; and quality of the thin section. The point-count and grain-size measurements were performed by Dr. Michael Wilson. All samples have been documented with several digital photomicrographs each.

\section{RESULTS}

Of the 50 samples examined as part of this study, 35 are sandstones or pebbly sandstones, two are pebble conglomerates, two are tuffs, and 13 are shales of some type (silty, sandy, or pebbly). The shales, conglomerates, and tuffs do not constitute conventional gas reservoirs, and have not been analyzed in detail; they are discussed separately in a later section of the report. The sandstone samples range from very fine-grained and very silty to coarse-grained and slightly pebbly. Sand composition is some mixture of quartz, feldspars, and volcanic and/or metasedimentary lithic fragments, commonly with abundant mica flakes and occasional lignitic organic fragments. Petrographic observations and corresponding core analyses for all sandstone samples are summarized in table 3 . For the samples studied here, variations in sand texture and composition (which are interdependent to some extent) are the primary control on the evolution of sandstone porosity and permeability with burial. Sand composition varies over time and, to some extent, geographically within the basin as well. Lateral and vertical changes in sand texture on a relatively small scale are typical in a fluvially-dominated non-marine basin such as the Tertiary of the Cook Inlet. Any attempt to predict the location and properties of a tight gas reservoir must be based on a geologic model (stratigraphic target, depositional model) that defines these primary controls. The following sections present more detailed discussions of petrographic observations on sandstone texture, detrital composition, diagenetic alteration, and pore systems. These are followed by a brief description of the non-reservoir rock types (shales and tuffs) sampled for this study.

\section{SANDSTONE TEXTURE}

Of the 33 sandstone samples examined for this study, seven are dominantly very fine-grained, eight are fineto medium-grained, five are fine- to coarse-grained, and 13 are medium- to coarse-grained; several of the samples which are fine-grained or coarser are also slightly pebbly. These sandstones are mostly well sorted. The pebbly sandstones are typically bimodal, with discrete clast and sand matrix size populations. Some of the very fine sandstones are slightly to moderately shaly or silty, and only moderately well sorted. Sandstones that are fine-grained and coarser are generally matrix-free, although some display small amounts of pseudomatrix due to squashing of highly ductile components during compaction.

Quantitative grain-size measurements were obtained for 25 of the sandstones (table 4). Among these samples, the mean framework grain size (framework grains being defined as only those 30 microns and larger in diameter) ranges from $0.061 \mathrm{~mm}$ (coarse silt) to $1.34 \mathrm{~mm}$ (very coarse sand), with a median of $0.27 \mathrm{~mm}$ (lower mediumgrained). The median sorting value (defined as the standard deviation of grain size measurements, in phi units) is 0.55 , corresponding to well-sorted grains. Details of mean size, sorting, and size distribution for individual samples are presented in table 4 . The contrast in sand grain size distribution is illustrated in figure 4, for two samples from similar depths in the Swanson River Field.

The full spectrum of measured grain-size distributions is illustrated in figure 5. Samples with similar distributions have been color coded accordingly.

The groups of sandstones with similar size distribution profiles are identified and characterized further in table 5. Only a few sandstones exhibit grain size distributions other than those of the four main textural groupings: a siltstone from the Halasko King 1B $(13,435.5 \mathrm{ft})$, and a couple of coarse to pebbly sandstones from the Cherryville A-15 (11,142 ft) and Dolly Varden D-2 (11,722.1 ft). The proportions and spatial distribution of different sand textural types in a given reservoir are a direct function of depositional facies.

For sandstones buried to similar depths, in the absence of significant pore-filling cement, those with a coarser mean grain size and better sorting will generally have better permeability at a given porosity. Cements can act to fill pores and block pore throats, thereby decreasing permeability; but, in small amounts, they can also have the effect of increasing the mechanical strength of a sandstone, actually preserving better permeabilities to greater depths than uncemented equivalents. The impact of an authigenic cement on the mechanical behavior 


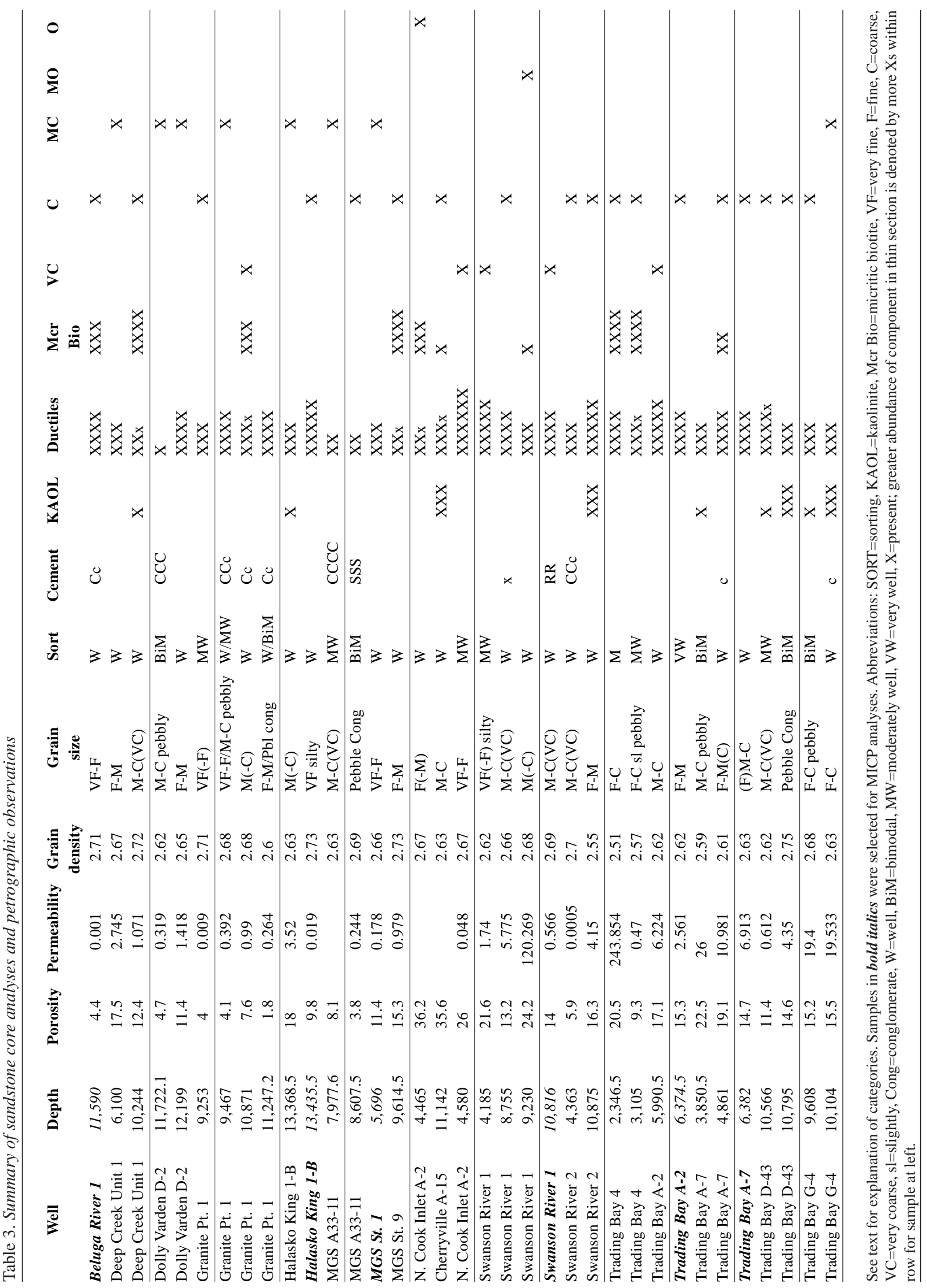




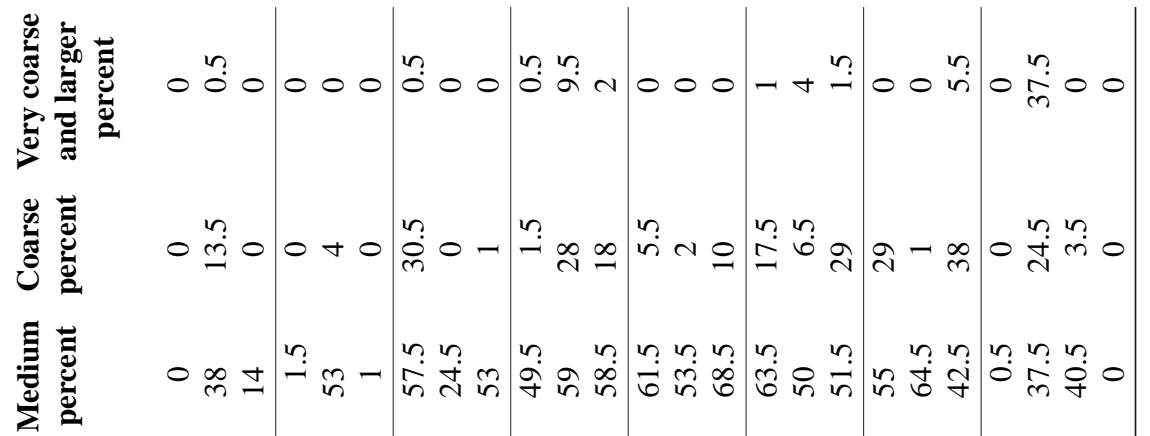

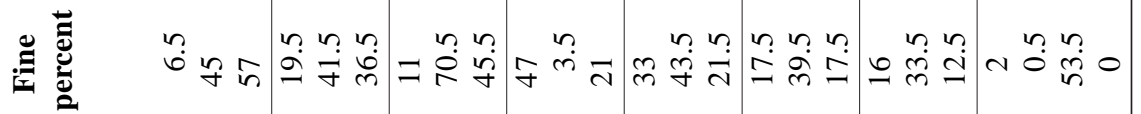

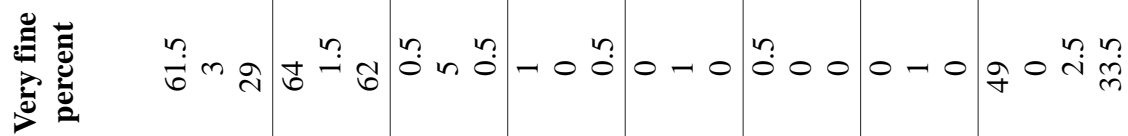

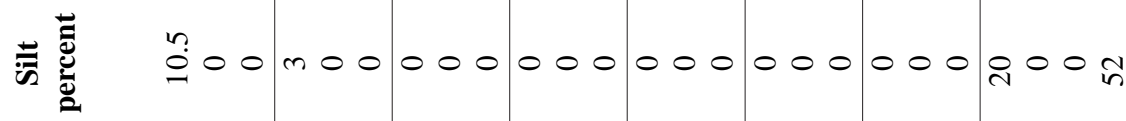

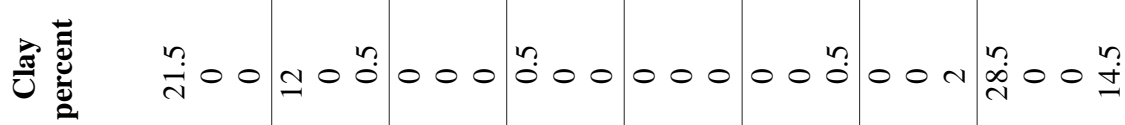

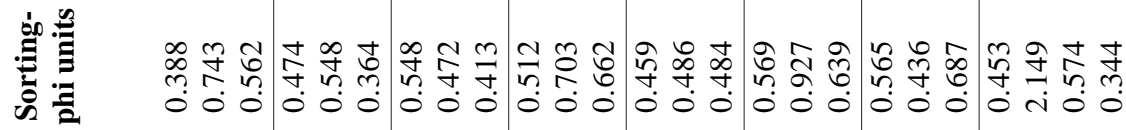

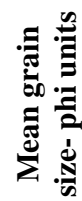

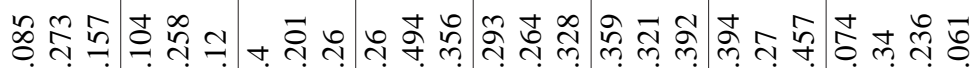

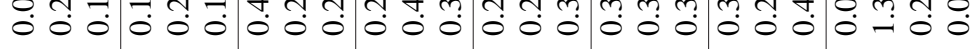

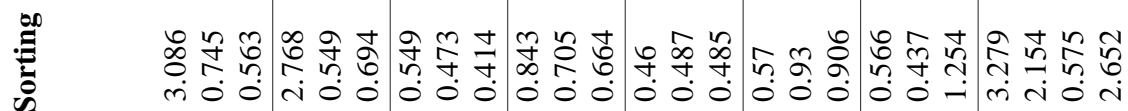

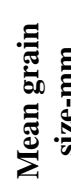

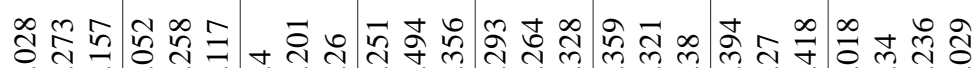

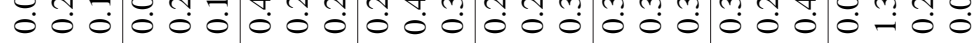

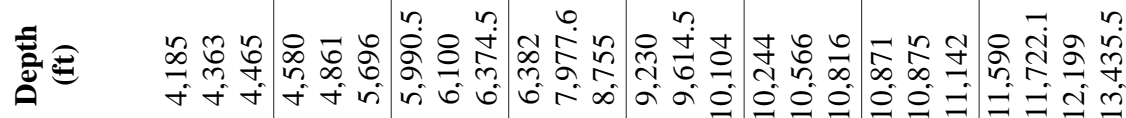

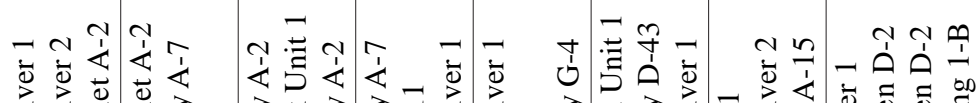

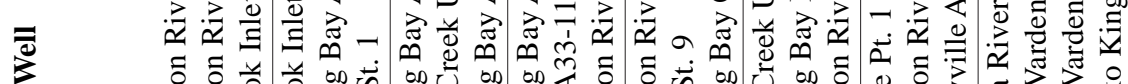

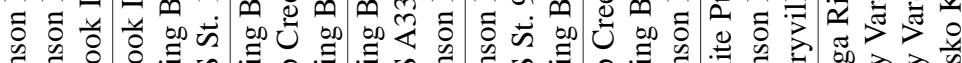

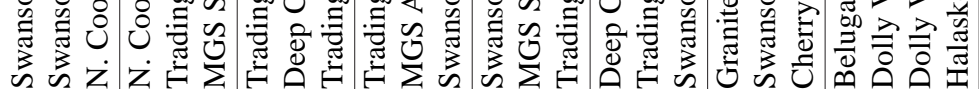



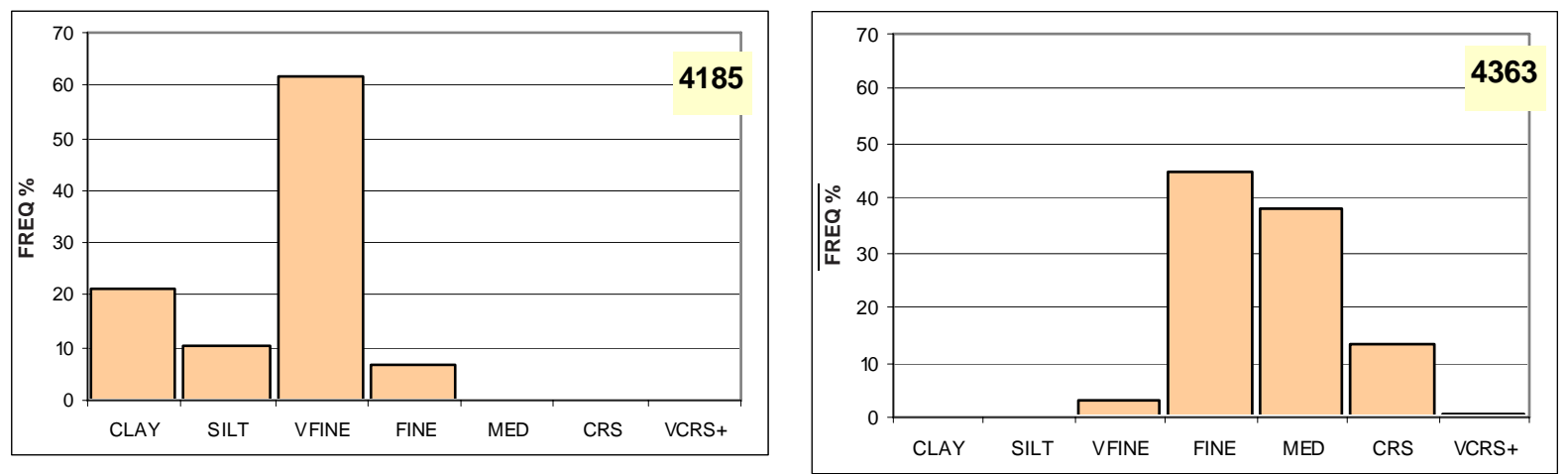

Figure 4. Grain-size distribution histograms for two samples from the Swanson River Field. Grain-size class histograms (frequency percent), based on 200 measured grains per sample, for the sandstone sample from 4,185' in the Swanson River Unit \#1, and that from 4,363' in the Swanson River Unit \#2 well. Mean framework grain size in the 4,185' sample is 85 microns (lower very fine), and 273 microns (lower medium-grained) at 4,363'. Overall sorting at 4,185' is poor due to the abundance of silty clay matrix, but the framework sand fraction is very well sorted; the sand grain size distribution at 4,363' is strongly skewed towards the coarser size classes.

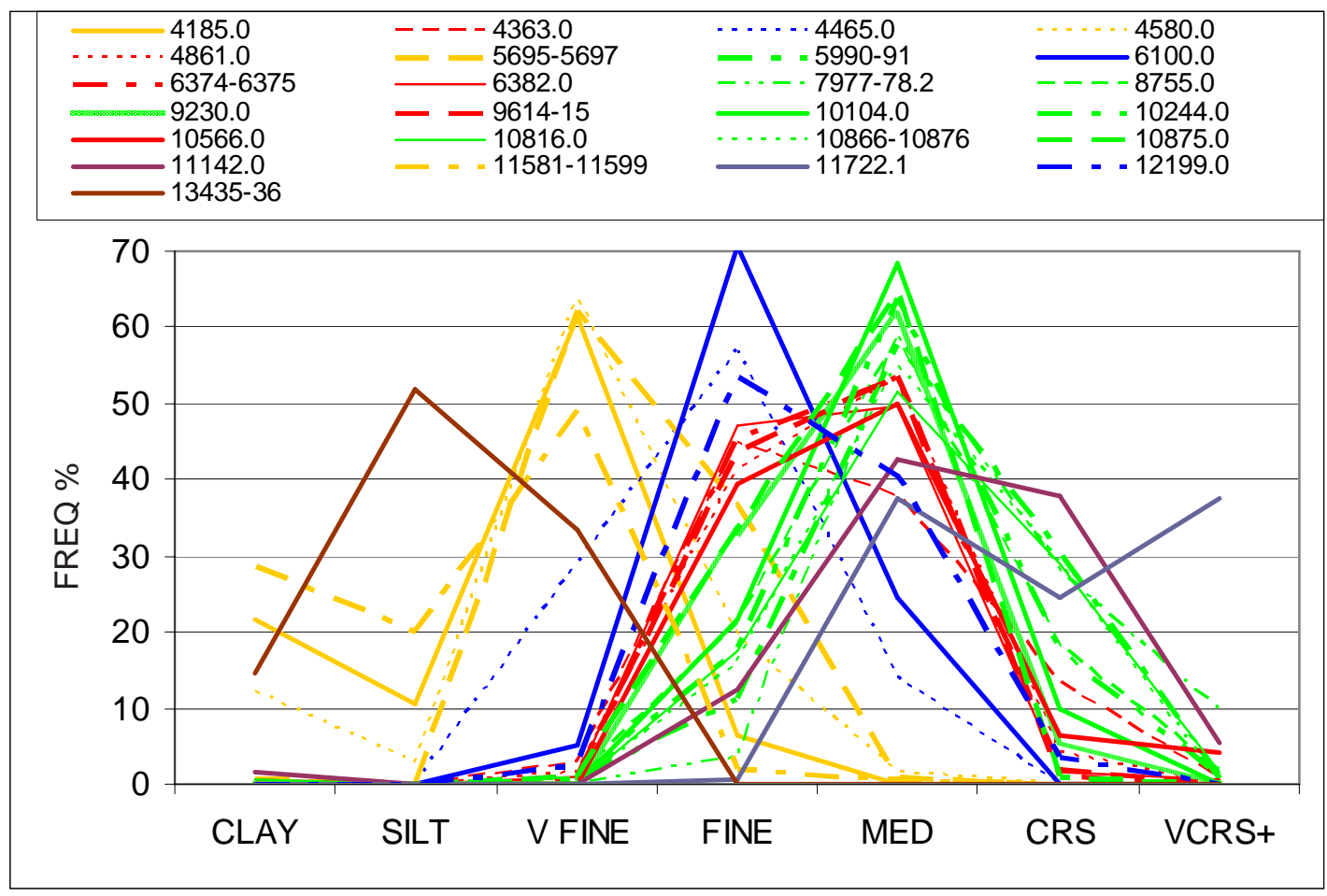

Figure 5. Measured grain-size distributions for all point-count samples. Frequency distribution by size class of measured detrital grain sizes for all sandstones selected for point-count analysis. Samples with similar distribution profiles share the same color, with different line styles. A few of the finest and coarsest samples have no similar counterparts. The major groups that are defined by their grain size distribution are: very fine, fine, fine to medium, and medium-grained sandstones. The rock unit that corresponds with these sample analyses is the same as in table 2 and table 5. For locations and details see figure 1 and table 1. 
Table 5. Grain-size statistics for sandstones with similar distribution profiles

\begin{tabular}{|c|c|c|c|c|c|}
\hline Group & Depth & Well & Unit & Sorting & MGS \\
\hline \multirow{4}{*}{ 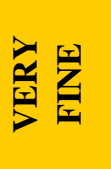 } & 4,185 & Swanson River 1 & Sterling & 3.086 & 0.085 \\
\hline & 4,580 & North Cook Inlet A-2 & Sterling? & 2.768 & 0.104 \\
\hline & 5,696 & Middle Ground Shoal St 1 & Tyonek & 0.694 & 0.12 \\
\hline & 11,590 & Beluga River 1 & Hemlock? & 3.279 & 0.074 \\
\hline \multirow{3}{*}{$\underset{\text { 冢 }}{\text { 至 }}$} & 4,465 & North Cook Inlet A-2 & Sterling & 0.563 & 0.157 \\
\hline & 6,100 & Deep Creek 1 & Beluga? & 0.473 & 0.201 \\
\hline & 12,199 & Dolly Varden D-2 & Hemlock? & 0.575 & 0.236 \\
\hline \multirow{6}{*}{ 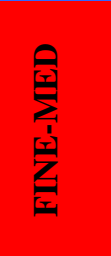 } & 4,363 & Swanson River 2 & Sterling & 0.745 & 0.273 \\
\hline & 4,861 & Trading Bay Unit A-7 & Beluga? & 0.549 & 0.258 \\
\hline & $6,374.5$ & Trading Bay Unit A-2 & Beluga? & 0.414 & 0.26 \\
\hline & 6,382 & Trading Bay Unit A-7 & Beluga? & 0.843 & 0.26 \\
\hline & $9,614.5$ & Middle Ground Shoal St 9 & Hemlock & 0.487 & 0.264 \\
\hline & 10,566 & Trading Bay Unit D-43 & Hemlock? & 0.93 & 0.321 \\
\hline \multirow{9}{*}{ 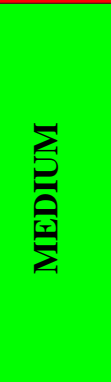 } & $5,990.5$ & Trading Bay Unit A-2 & Beluga? & 0.549 & 0.4 \\
\hline & $7,977.6$ & Middle Ground Shoal A33-11 & Tyonek & 0.795 & 0.494 \\
\hline & 8,755 & Swanson River 1 & Tyonek & 0.664 & 0.356 \\
\hline & 9,230 & Swanson River 1 & Tyonek & 0.46 & 0.293 \\
\hline & 10,104 & Trading Bay Unit G-4 & Hemlock? & 0.485 & 0.328 \\
\hline & 10,244 & Deep Creek 1 & Hemlock? & 0.57 & 0.359 \\
\hline & 10,816 & Swanson River 1 & Tyonek? & 0.906 & 0.392 \\
\hline & 10,871 & Granite Point 1 & Tyonek & 0.566 & 0.394 \\
\hline & 10,875 & Swanson River 2 & Tyonek? & 0.437 & 0.27 \\
\hline
\end{tabular}

Well name, stratigraphic unit (question marks for tentative assignments), overall sorting (standard deviation, phi units; higher values correspond to poorer sorting), and framework mean grain size (using only grains larger than 30 microns; in microns) for the grain-size distribution groupings identified in figure 5. MGS= median grain size for framework grains.

of a sandstone is a function of the abundance, distribution, and timing of the cement. Early pervasive cements significantly retard compaction, with very high resulting intergranular volumes; but the abundance of such cements leaves no effective pore system, and porosity and permeability are very low. Many samples have moderate (5-10 percent by volume) amounts of carbonate cement that is very patchily or spottily distributed, and appears to be relatively late, postdating any obvious compactional effects. Such cements have little impact on intergranular volume, because of their timing and distribution. But they also have little impact on permeability, as their relatively small volumes and irregular distribution leaves many permeable pathways available, even at the plug scale. This is illustrated in figure 6 .

Sandstone textures are determined by provenance and depositional processes, both of which vary over time and aerially across the basin. The ultimate reservoir quality of a sandstone is dictated by its mechanical properties, burial history, and cementation. As suggested in figure 6 , for most of the reservoir samples in this study, porefilling cement is too minor, too patchy, and too late to have much of an impact on reservoir quality. Thus, to predict sandstone reservoir quality is to predict mechani- cal properties and burial history. Additionally, clay content of sandstones must also be assessed and considered. The sandstone's mechanical properties are a function of texture (grain size, sorting, and matrix all affect the effective stress at individual grain contacts) and composition-a sandstone dominated by relatively strong ("rigid") crystalline grains such as quartz will behave very differently under a given amount of stress than will a sandstone with abundant grains with very little compressive strength (“ductile” grains, e.g., argillaceous grains such as shaly rock fragments, mica and lignite flakes).

\section{DETRITAL COMPOSITION}

The detrital composition of these Cook Inlet sandstones (table 6) consists of a mixture of grains derived from crystalline basement (quartz, feldspars, micas, heavy minerals), from active and reworked volcanic terranes (various volcanic rock fragments, plagioclase, pumice, glass shards), and from older sedimentary and metasedimentary deposits (chert, low-grade metasedimentary fragments). Composition varies both with provenance (which evolves over time and can vary somewhat geographically as well as vertically) and texture (there 


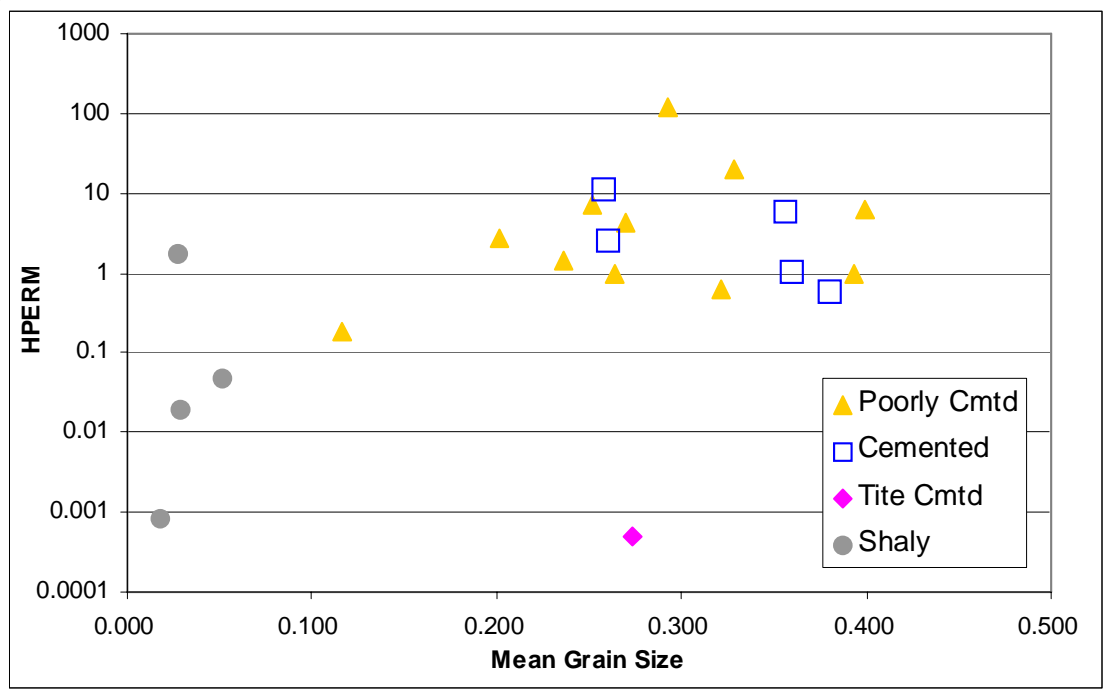

Figure 6. Overall mean grain size vs. permeability, coded by cement or shale matrix content. Semi-logarithmic crossplot of mean grain size ( $\mathrm{mm}$; average of all detrital grains, not just the sand framework) and measured plug permeability (md). All point-count samples with permeability measurements are included, and have been coded based on the dominant pore-filling phase: Shaly samples have common interstitial clay matrix. Poorly cemented samples are matrix-poor and have less than 5 percent pore-filling cement. Cemented samples have 5-10 percent pore-filling cement. Tight cemented samples have $>20$ percent pore-filling cement. There is little distinction between the poorly cemented and cemented samples, nor does grain size have a consistent effect on permeability over the range of upper fine to upper medium sand (about 0.2-0.45 mm). Note that the overall mean grain size, rather than the framework grain size, has been used in this plot to account for the impact of silt and clay matrix on permeability. For the fine to medium-grained sandstones in this sample suite, matrix content is typically very low, and there is little distinction between overall and framework mean grain size. Cmtd=cemented.

is a weak correlation between grain size and certain grain types that are especially resistant or extra prone to abrasion and fragmentation during transport). A correlation of sands on the west side of the basin versus the east side of the basin was not attempted with our data set. In general, the grain types derived from crystalline basement are mechanically rigid, subject to fracturing rather than plastic deformation. Most of the metasedimentary fragments are quite ductile and deformable. Volcanic material tends to be mixed in its mechanical properties, depending on composition and degree of alteration. There do appear to be consistent stratigraphic trends in sand composition (see Provenance section), so knowing a target reservoir's age can be useful in predicting its mechanical properties and reservoir quality.

The major detrital grain type in these sandstones is monocrystalline quartz. Other important grain types in most sandstones include polycrystalline quartz (of both plutonic and metamorphic origin) and chert (some of it clearly radiolarian-bearing), with lesser amounts of plagioclase and potassium feldspars, granitic rock fragments, silicic volcanic rock fragments, and quartz- rich argillite fragments. Minor phases present in most sandstones (and in some cases volumetrically significant) are micas (mostly biotite and muscovite, with some chlorite), sedimentary intraclasts (shale, silt, and sand), argillaceous metasedimentary rock fragments, lignitic organic flakes, andesitic to basaltic volcanic fragments, and heavy minerals (epidote, zircon, tourmaline, rutile, sphene, garnet, apatite, hornblende). Rare but noteworthy grain types include volcanic glass (both as pumiceous rock fragments and as individual shards), tuffaceous volcanic fragments (welded tuffs, vitric-crystal tuffs), quartzite, meta-gabbro, and recycled sandstone fragments whose composition is very similar to that of the associated sand (quartz, chert, phyllite, plagioclase), but which is internally strongly compacted, with extensively deformed ductile grains and little remnant intergranular volume (in sharp contrast with the sand in which the sandstone fragment now resides). Some of the important grain types are illustrated in photomicrographs (fig. 7).

In sandstones with pronounced primary laminations (planar laminations, ripples and ripple drapes), the laminations are typically composed of concentrations of mica 


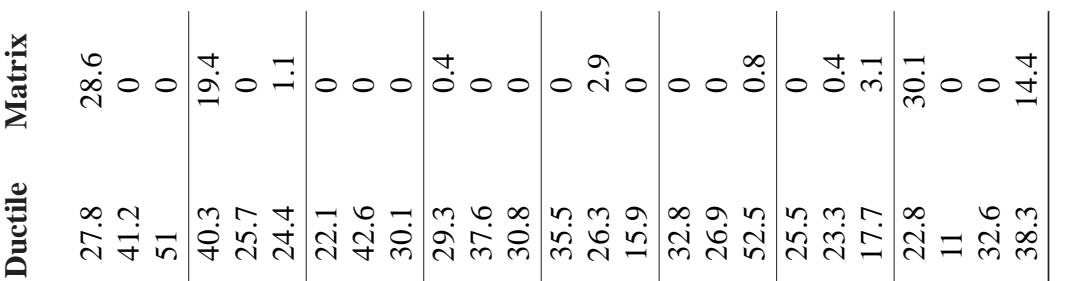

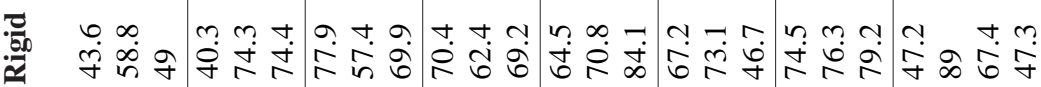

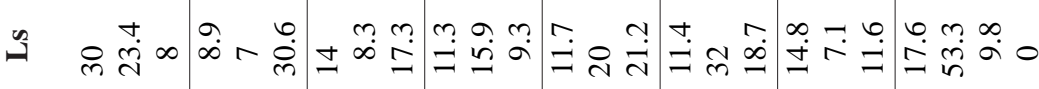

青 设

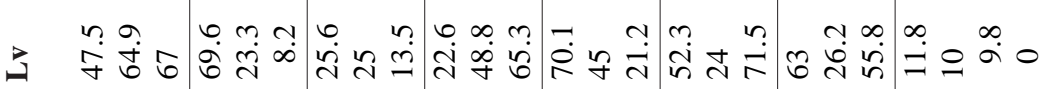

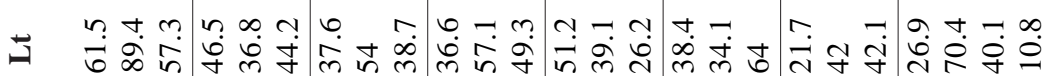

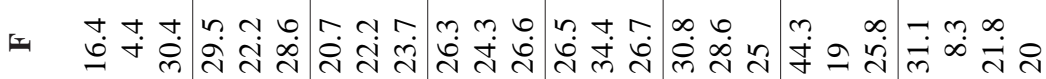

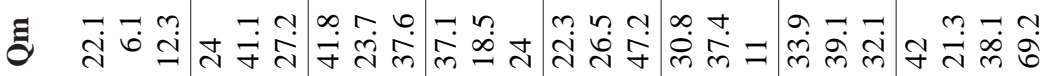

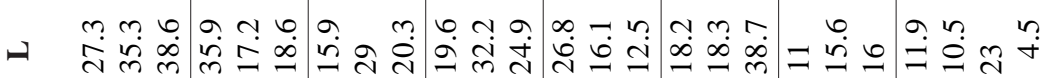

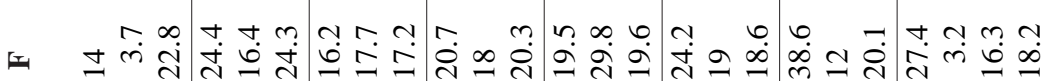

•

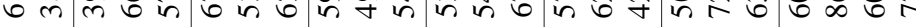

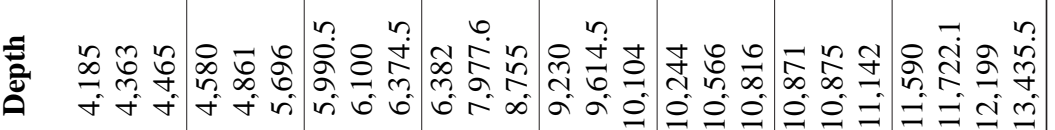

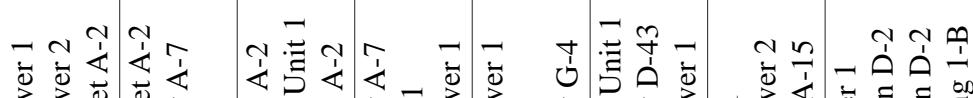

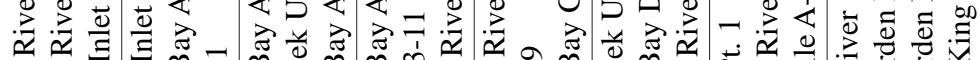




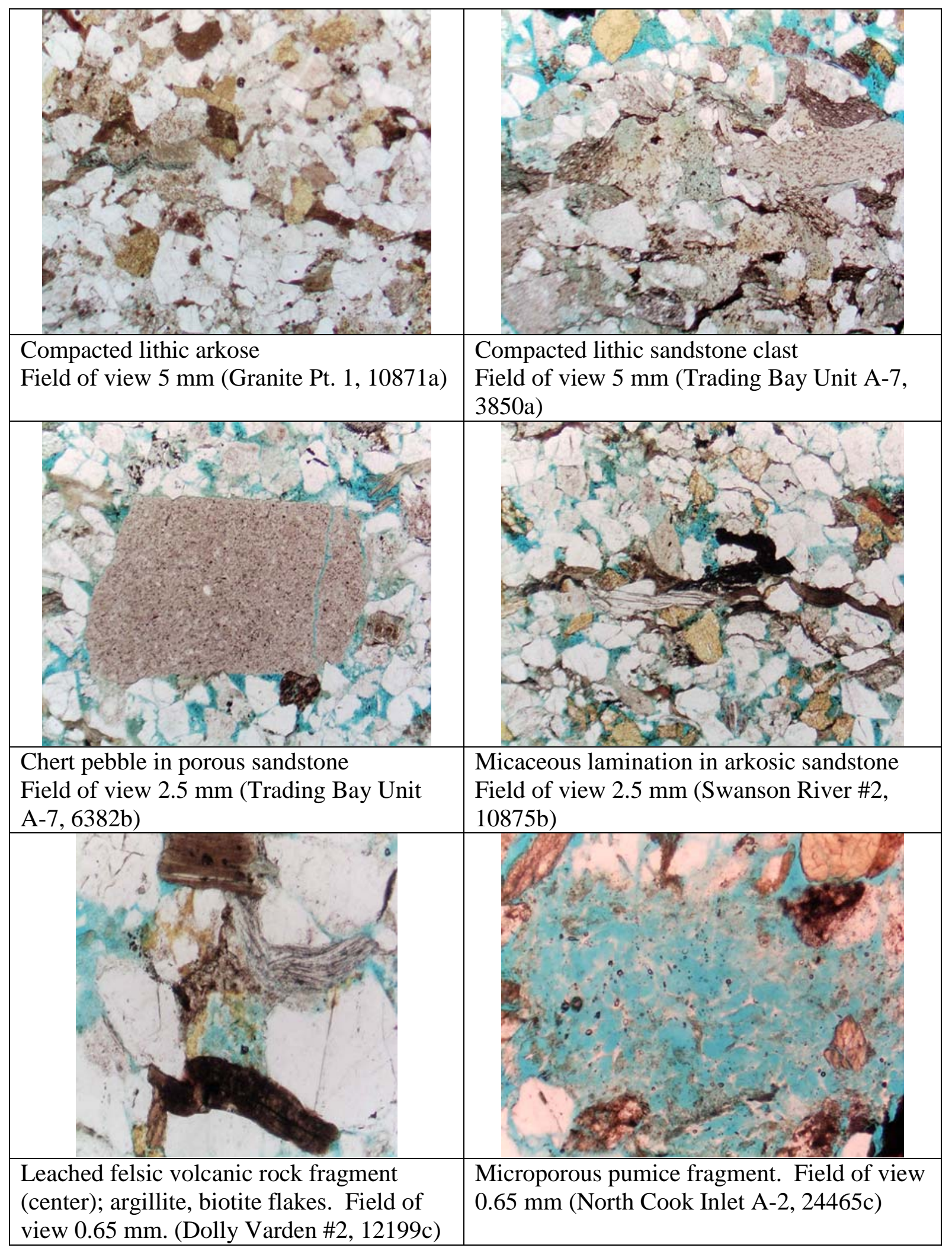

Figure 7. Selected plane-polarized light photomicrographs illustrating detrital clasts in Cook Inlet sandstones; name of well is followed by the samples' depth. 
and/or lignite flakes, some small rip-up clasts, and a finer sand grain size than the adjacent sandstone matrix. Large mica flakes are a common feature in many sandstones, even coarser-grained ones with no apparent lamination or segregation of grain types. Such flakes are prone to plastic deformation and splaying; biotite is also liable to be replaced by microcrystalline siderite (see Authigenic phases).

\section{DIAGENESIS}

Relatively rapid, deep burial of Tertiary sandstones in Cook Inlet Basin has favored compactional processes over cementational ones, although the more deeply buried sandstones exhibit some evidence of burial diagenetic chemical reactions, ranging from authigenic clays to leaching of unstable grains. Based on point-count data, intergranular volumes range from 2.7 to 38 percent, with a median of 13.7 percent; average volume loss due to compaction (corrected for changing total volume) is over 24 percent by volume. The amount of pore-filling cement ranges from 0.3 to 33 percent, with a median of about 5 percent. With increasing burial, intergranular volume continues to fall in ductile-rich sandstones, while authigenic phases become increasingly common, leading to rapid declines in permeability and permeability.

\section{AUTHIGENIC PHASES}

In most samples, authigenic phases are volumetrically minor, although they may still have a significant impact on petrophysical properties. The only volumetrically significant pore-filling phases are calcite cement and kaolinite (thin section identification only). Calcite occurs as a pore-filling cement, typically as irregular isolated patches, and as a minor grain-replacing phase (most commonly plagioclase feldspar). In a few samples, cementation appears to have been relatively early (precompaction), and calcite forms a pervasive subpoikilitic pore filling. More commonly, carbonate cementation was not abundant or early enough, and has had little noticeable effect on the extent of mechanical compaction. The late timing of most carbonate cement is likely to be related to decreasing carbonate solubility with depth, and with the onset of plagioclase leaching and alteration (releasing aqueous $\mathrm{Ca} 2+$ and shifting solution equilibrium towards calcite precipitation). Authigenic kaolinite occurs as microcrystalline, microporous aggregates that fill intergranular pores and replace framework grains. Kaolinite is particularly common in most of the coarser-grained samples from the Trading Bay area. Pore-filling kaolinite is typically present as isolated patches or spots up to 1-2 $\mathrm{mm}$ across, engulfing several sand grains; leaching of unstable phases (volcanic fragments, plagioclase) is a common association.

Microcrystalline pyrite occurs within clay matrix in shaly samples, along some bedding contacts, and as a partial replacement of some clasts (particularly chert). Traces of authigenic sphene are associated with altered micas. In a number of samples, biotite flakes have been replaced by microcrystalline siderite, as a microporous "dilated" aggregate several times larger than the original mica flake. Other minor phases, usually present in only the most volcanic-rich samples, include smectite, as a pore-filling clay; clinoptilolite(?), as pore-filling crystals; and corrensite(?), as a fibrous pore-lining clay.

Because of the scarcity of authigenic phases in these sandstones, it is rare to observe two or more phases in a single sample with a clear superpositional relationship. With the exception of a few rare samples with pervasive early calcite cement, mechanical compaction appears to predate or at least overlap with the development of most of the authigenic minerals noted. Rare zeolite (clinoptilolite?) cement postdates calcite, which in turn postdates compaction. The dilation and sideritization of biotite flakes can take place fairly early, before significant compaction; the siderite aggregates are then subject themselves to plastic deformation with further burial. The inferred paragenetic sequence is presented schematically in figure 8.

The paragenetic sequence illustrated in the schematic chart (fig. 8) is based on relationships observed in this study. The true maximum burial depths of several of the samples may be significantly deeper (3,000 ft or more) than current depths, complicating the interpretation of relative timing. The variation of burial range within the sample suite influences the depth/reservoir quality comparisons. Mechanical compaction has the greatest volumetric impact on the sandstone pore system for the great majority of samples. As indicated in the chart above, most authigenic phases do not develop until burial depths of 8,000 ft or more, by which point compaction has already considerably reduced the size of pores and pore throats.

\section{MECHANICAL COMPACTION}

Mechanical compaction of sandstones entails the slippage, rotation, fracturing, and plastic deformation of individual grains (depending on local stresses and the grains' mechanical properties), resulting in an overall loss of bulk volume for a given number of sand grains, and a decrease in diameter for most pores and pore throats (fig. 9). In well-sorted quartzose sandstones, the stress due to the overlying sediment column is fairly uniformly distributed at multiple grain contacts, quartz crystals are strong enough to resist fracturing (except in the coarsest sands), and plastic deformation is unknown (short of metamorphic conditions). Until substantial pressure solution takes place, quartzose sandstones typically exhibit intergranular volumes on the order of 20-22 percent or more even at burial depths of 3-5 km. In sandstones with significant amounts of ductile material and large 


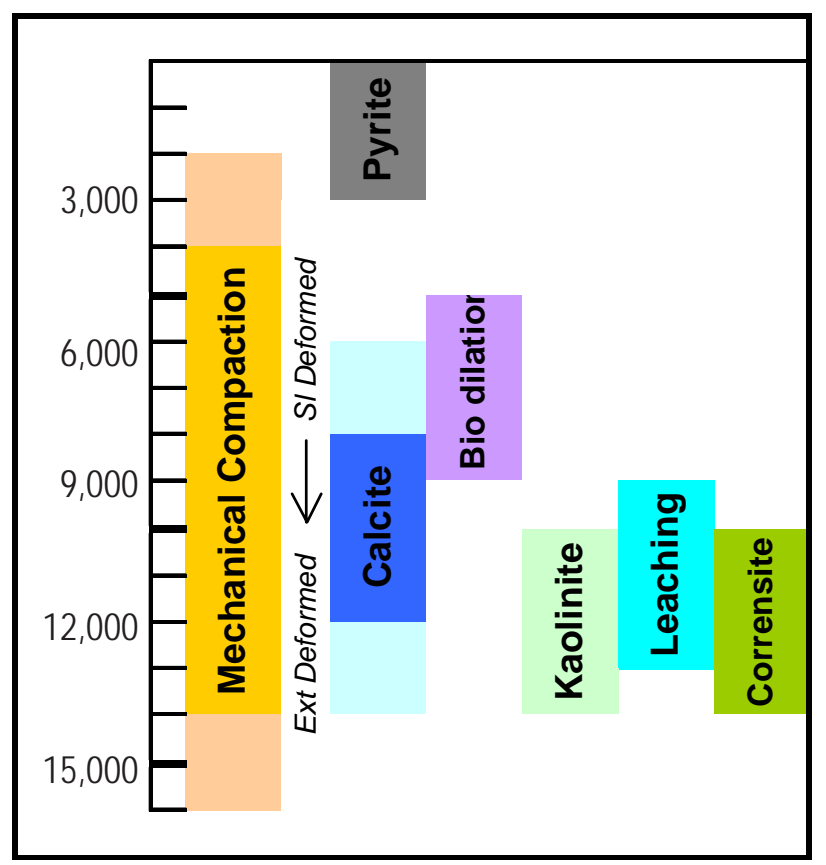

local contrasts in grain mechanical properties, grain fracturing and plastic deformation are the norm, and are evident at quite shallow depths $(<2 \mathrm{~km})$. The extent of ductile deformation depends on the nature of the ductile grains (with soft mudstone rip-ups being far more easily deformed than a quartz-rich argillite rock fragment or muscovite mica flake), sand texture (defining the number and orientation of grain contacts and the resulting local stresses), and the abundance and distribution of the ductile grains. In many lithic-rich sandstones, ductile content must reach a certain threshold value (typically on the order of 20-25 percent of the sand detrital framework) before the sandstone's mechanical behavior is significantly altered. Ductile content in the point-count samples from this study ranges (as a percentage of the detrital framework) from 11 to 52 percent, with a median of just over 30 percent; only three of the samples have fewer than 20 percent ductiles, and only one has fewer than 15 percent (Dolly Varden D-2 11,722.1 ft, a chert-rich pebbly sandstone). No obvious trends are apparent when ductile content is plotted against IGV (fig. 10): clearly sand texture, burial history, and the types of ductiles are important variables as well. Table 7 is a list of major detrital grain types in approximate order of increasing ductility. The more ductile the grain type, the shallower the onset of plastic deformation, and the more severe the deformation at any given burial depth.

Estimates of relative packing density of the sand grain framework (from open, with primarily floating and point grain-to-grain contacts, to closed, with mostly straight or crenulated contacts) are a useful qualitative tool, although difficult to apply consistently to sandstones with
Figure 8. Generalized paragenetic sequence, Cook Inlet Tertiary sandstones; schematic sequence of events during prograde burial diagenesis for typical Cook Inlet Tertiary sandstones. Not all processes occur in all sandstones. Mechanical compaction is the most universal; pore-lining corrensite (and rare zeolite cements, not shown) is quite unusual, and present in trace amounts only in the most volcanogenic sandstones. Pyrite and leaching of unstable grains (some feldspars, heavy minerals, mafic volcanic fragments) usually impact 1 percent or less of sandstone volume. Kaolinite, when present, is typically 1-3 percent by volume (up to almost 6 percent in the samples in this study). With a few exceptions of sandstones pervasively cemented by carbonate, calcite and other carbonates rarely exceed 5 percent of the sandstone's volume in this sample set. Replacement of biotite by microporous aggregates of micritic siderite ("bio dilation") can affect up to 5-10 percent of a sandstone's volume, but in most cases has a negligible impact on the overall pore system. Ext=extensively; Sl=slightly

very different grain sizes or sorting. We can calculate an intergranular volume (IGV) from point-count data. As noted above, for quartzose sandstones at similar burial depths, IGV values rarely fall below 20-22 percent. For the Cook Inlet sandstones in this study, measured IGV values range from 2.7 to 38 percent, with a mean of 16.1 percent and a median of 13.7 percent. There is a consistent relationship between IGV and current burial depth for most, though not all, the samples in this study (fig. 11).

The linear trend highlighted in the chart for the decrease in IGV with depth indicates a loss of about 3.6 percentage points per 1,000 ft burial. The IGV-depth relationship is physically unlikely to be linear, but over a limited depth range a linear approximation is probably reasonable. Samples that fall off this trend line of maximum IGV at a given depth can be interpreted as having experienced greater compressional stresses than their current depths would indicate, that is, they have undergone tectonic uplift after achieving maximum burial. The sample highlighted with a pink arrow in figure 11 (Middle Ground Shoal State 9, 9,614.5 ft) would have the "proper" IGV, as indicated by the trend line, if its depth were increased by about 3,000 ft. If all the samples in the Cemented group are similarly shifted back to the trend line, the shallowest occurrence of a cemented sample would be at approximately 8,000 ft (Trading Bay Unit A7, 4,861 ft plus 3,000 ft uplift). Using this approach, the maximum apparent uplift for these samples would be on the order of 5,000 ft, for the sample currently at a depth of 5,696 ft (Middle Ground Shoal State 1). Large-scale recent tectonic structures are characteristic of the basin (Haeussler and others, 2000), and can involve signifi- 


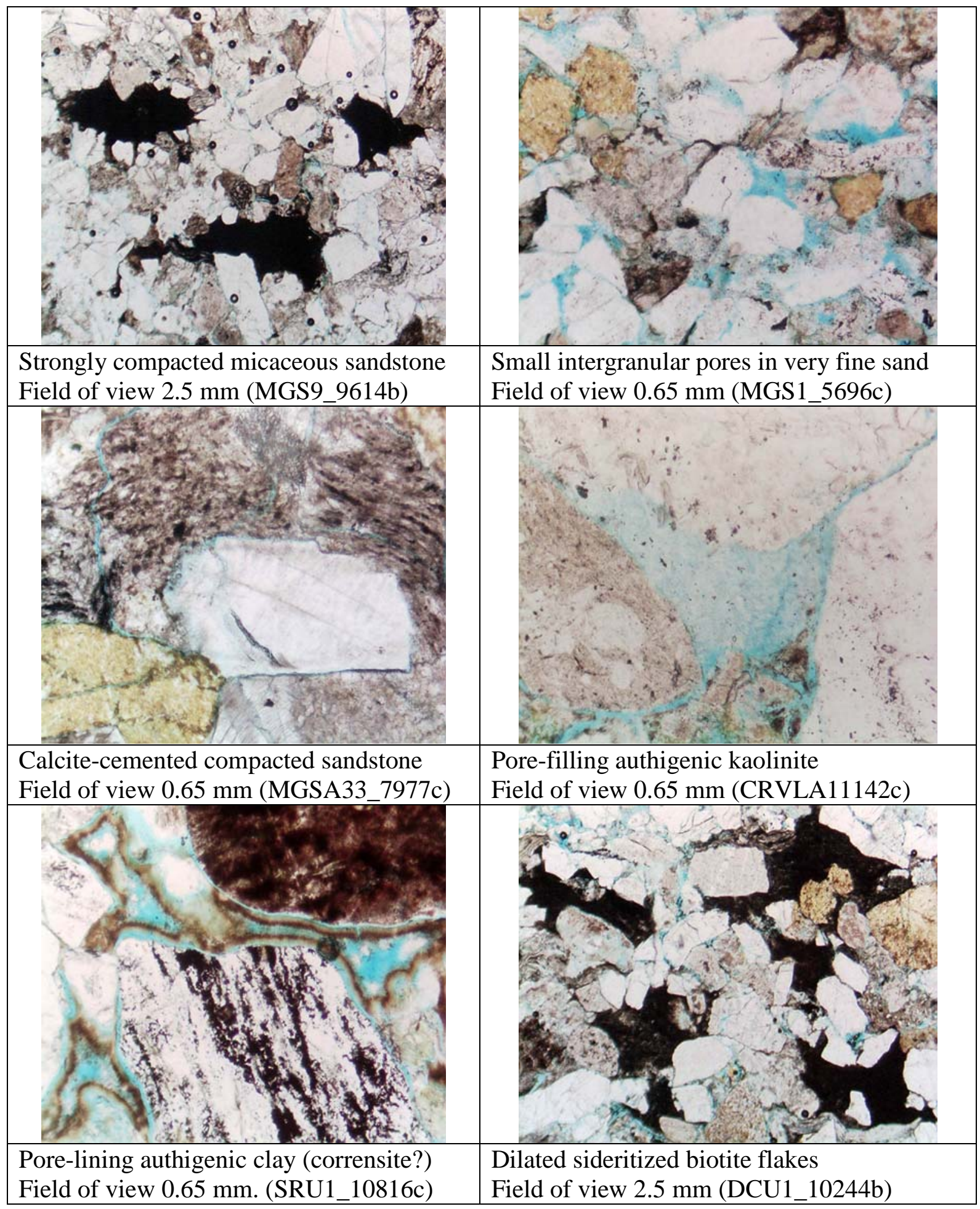

Figure 9. Selected photomicrographs illustrating diagenetic features of Cook Inlet sandstones 


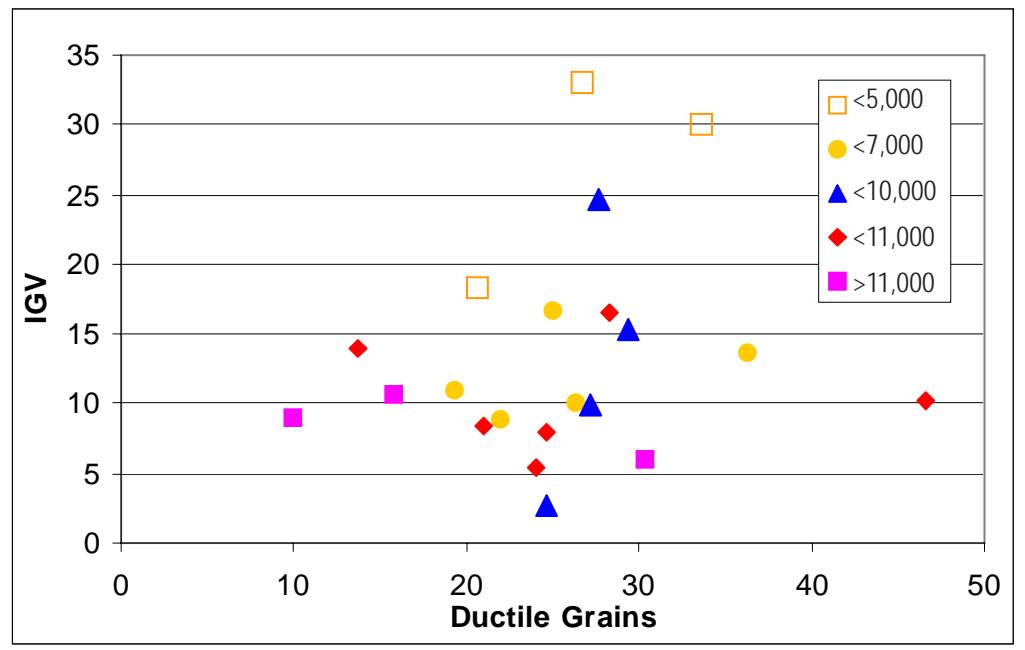

Figure 10. Ductile grain content vs. intergranular volume, grouped by current burial depth. Crossplot of ductile grain content (percent by volume) vs. intergranular volume (IGV percent by volume) for point-count samples (excluding the very fine-grained sandstones), grouped by current burial depth. No clear trends or threshold effects are evident.

Figure 11. Intergranular volume (\%IGV) vs. current burial depth for all pointcount samples. Intergranular volume (from point-count data) vs. current burial depth, with samples coded by cement or matrix content: poorly cemented ( $<5 \%$ pore-filling cement), cemented (5-10\% cement), tite cemented (>20\% cement), shaly (>10\% matrix). The dashed gray line is a qualitative linear trend line for the maximum IGV values at a given depth. Samples that fall off this line may have been more deeply buried at one time, then uplifted during an

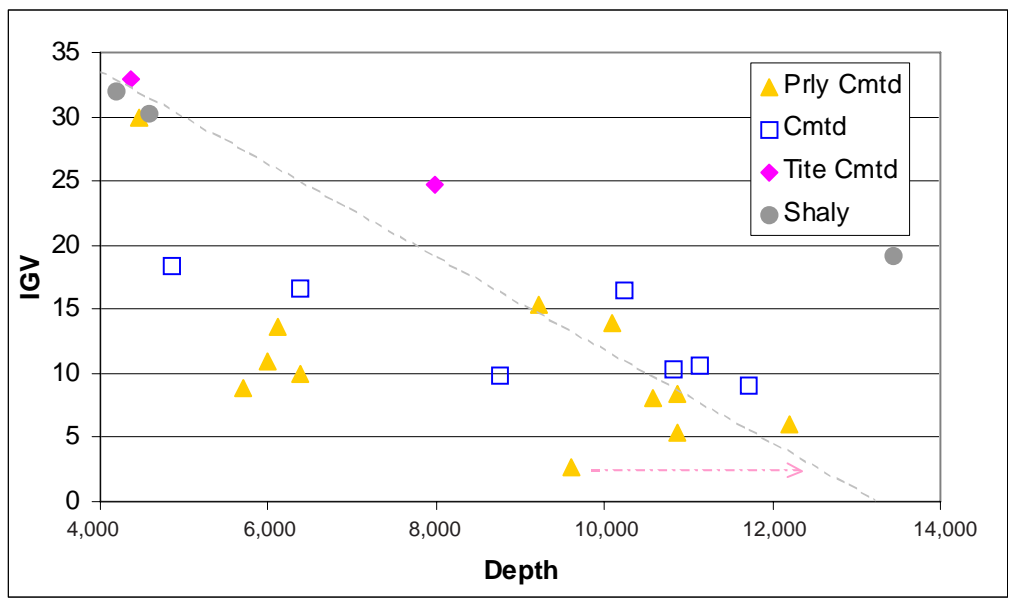
erosional unconformity. The pink arrow illustrates one such situation, where the poorly cemented sample may have been buried deeper than 12,000' before undergoing about 3,000' of uplift to its current burial depth.

Table 7. Major grain types in approximate order of increasing ductility, top to bottom

\section{Behavior Grain types

Rigid Quartz

Feldspars: (potassium feldspar usually more rigid than plagioclase)

Transitional Quartzose rock fragments (chert, felsic volcanic rock fragments, quartz-rich schists, quartzites)

Ductile Micas

(Muscovite usually more rigid than Biotite)

Mafic volcanics (Fresh > Altered)

Argillaceous metasedimentary fragments

Muddy rip-up clasts; lignitic flakes

\section{Notes}

Tend to fracture rather than deform plastically

May fracture, deform, or develop microstylolitic contacts

Bend or splay rather than deform; subject to chemical alteration Will readily deform plastically, may form pseudomatrix 
cant uplift and erosion, which, in some unpublished models may be greater than $10 \mathrm{~km}$.

Ductile content of these sandstones is generally rather high. One standard approach to classifying the mechanical behavior of a sandstone is to divide its components into rigid and ductile grain types, and locate the sample on a ternary plot of Rigid grains, Ductile grains, and Matrix - known as the RDM ternary plot. The RDM plot for the samples in this study, grouped by age and geographic area, is presented in figure 12 .

The amount and types of ductile grains is a measure of the potential of a sandstone to undergo accelerated mechanical compaction. The point counts performed for this study provide additional information on the actual extent of plastic deformation that various ductile grain types have experienced. Three categories of progressively greater deformation were defined and counted: Undeformed, Slightly Deformed, and Extensively Deformed. Each ductile grain (including micas) encountered during the point count was classified into one of these three categories. The results are illustrated in ternary plots of Undeformed-Slightly Deformed-Extensively Deformed ductile grains (fig. 13) and micas (fig. 14); samples have been grouped by current burial depth (bearing in mind the potential for significant uplift indicated for some of the samples).
There is a general tendency for less deeply buried sandstones to contain less extensively deformed ductile grains, but there is no consistent relationship between depth and degree of deformation. The one sample with nothing but undeformed grains (Halasko King 1B) is also the most deeply buried of all, at 13,435 ft. Yet it is also very fine-grained and relatively ductile-poor. As noted above, the presence of highly ductile grains is not, in and of itself, sufficient to ensure that they undergo plastic deformation during compaction; in ductile-poor samples, particularly if finer-grained, the soft grains are largely protected from load-bearing stresses. Some of the shallow samples are liable to have undergone significant uplift after maximum burial, further complicating the interpretation of depth-compaction relationships. Grain size, the abundance and distribution of ductile grains, and maximum burial depth (i.e., maximum effective stress) all play a role in determining mechanical behavior during burial compaction.

Undeformed mica flakes are much less common than undeformed ductile grains in general (fig. 14). By virtue of their anomalous shape (elongate flakes) and size (long dimensions usually several times greater than associated quartz grain diameters), micas are much less likely to avoid compressional stresses, even at low abundances, than are other ductile grains. Biotite tends to be the most

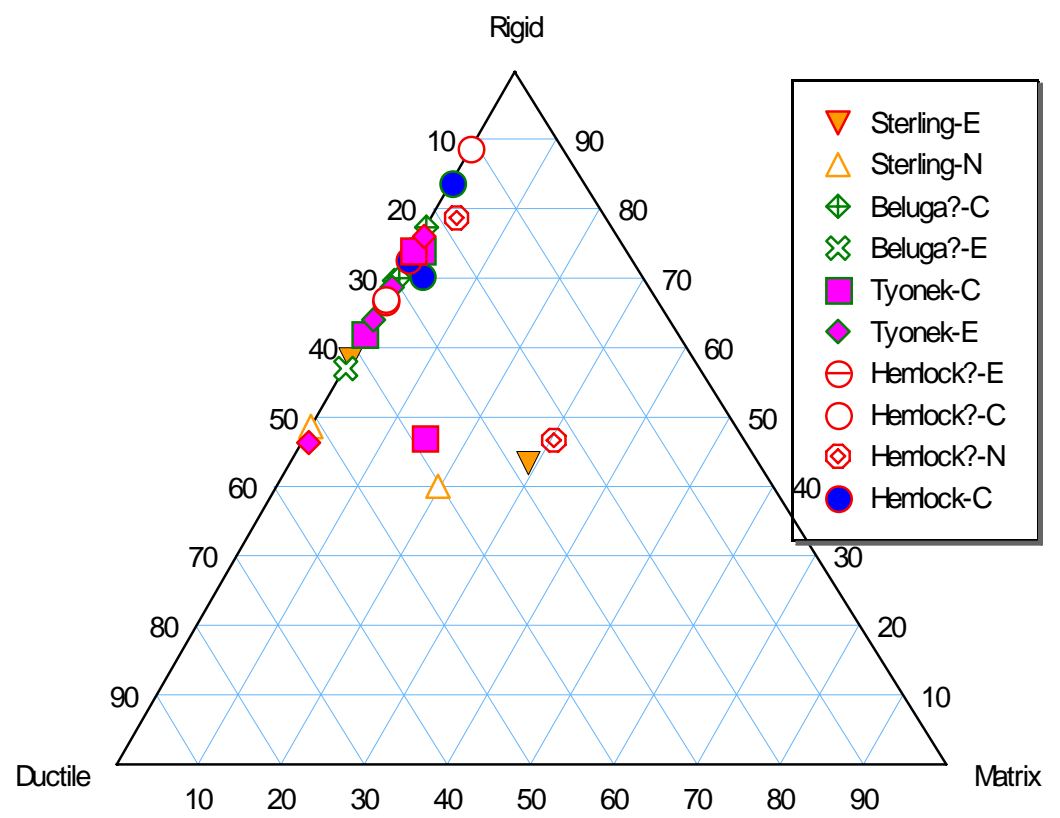

Figure 12. Rigid-Ductile-Matrix ternary plot of Cook Inlet point-count samples, by age and location. Ternary plot of rigid grains, ductile grains, and matrix for all point-count samples. Matrix content is generally quite low (by design) except for the finer-grained sandstones. There is some tendency apparent for the samples from the Central area to be slightly more rigid-rich than those from the East or North. 


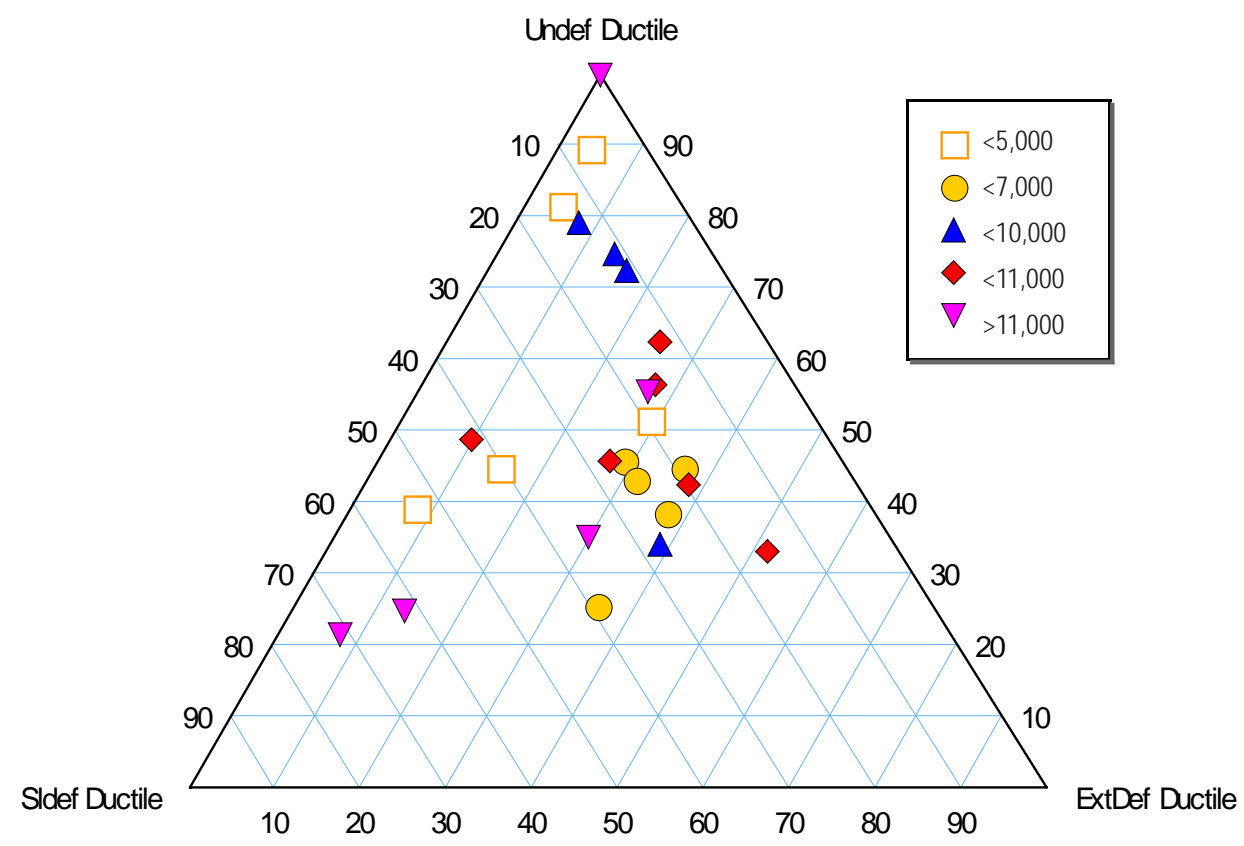

Figure 13. Ternary plot of undeformed-slightly deformed-extensively deformed ductile grains. Ternary plot of the normalized percentages of undeformed, slightly deformed, and extensively deformed ductile grains in all point-count samples. The samples have been grouped according to their current burial depths (<5,000', 5,000-7,000', 7,000-10,000', 10,000-11,000', and >11,000').

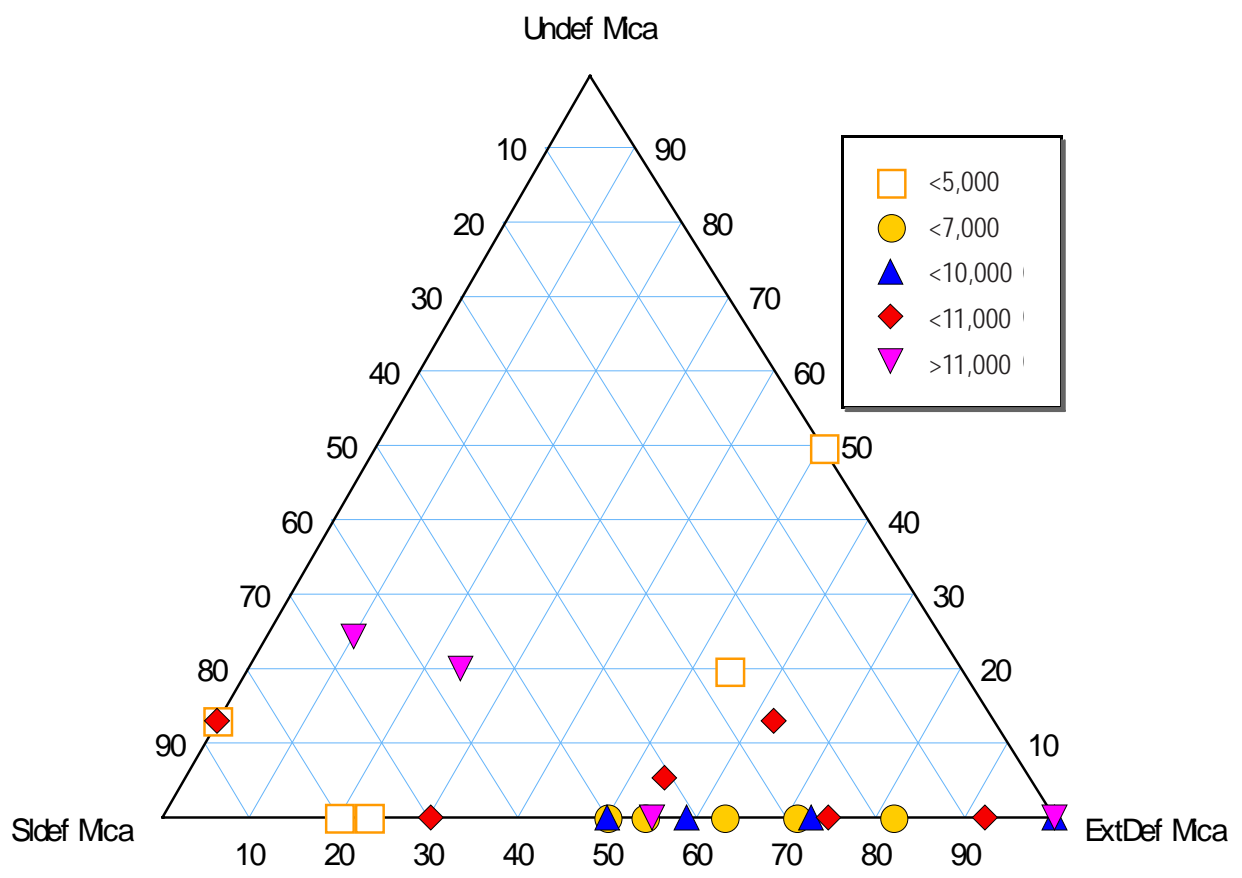

Figure 14. Ternary plot of undeformed-slightly deformed-extensively deformed mica flakes. Ternary plot of the normalized percentages of undeformed, slightly deformed, and extensively deformed mica grains in all point-count samples. The samples have been grouped according to their current burial depths (<5,000', 5,000-7,000', 7,000-10,000', 10,000-11,000', and $\left.>11,000^{\prime}\right)$. 
easily deformed and altered; muscovite is rarely altered; and chlorite is typically unaltered and at most slightly deformed.

Undeformed mica flakes rarely exceed 10 percent of the total mica population. As was the case for ductile grains in general, there is a weak tendency for more deeply buried samples to have more strongly deformed micas, but there is considerable scatter due to differences in grain size, ductile grain content, possible orientation of thin section, and amount of tectonic uplift. More so than other ductile grains, mica flakes are commonly concentrated along discrete laminations, thereby maximizing the degree of deformation that they undergo, while at the same time minimizing the impact of this deformation on bulk rock properties such as porosity and horizontal permeability.

The value of measures of sandstone compaction, from qualitative assessments of packing density to point-countbased quantification of ductile grain deformation, lies in the consistent relationship between reservoir quality and compaction in these generally lightly cemented sandstones. To quantify the effects of sand texture, composition, and stress history on reservoir quality would require a more comprehensive sample and wireline data set than is available for this study. But even on the basis of the current findings, it is possible to recognize anomalously shallow (uplifted) samples and to prioritize potential reservoir targets based on models of age (composition), facies (texture), and burial history.

\section{PORE SYSTEM}

The pore systems of lightly cemented sandstones are largely defined by sand texture (grain size, sorting, matrix content) and compaction. In relatively ductile-rich sandstones, such as many of the Cook Inlet samples in this study, mechanical compaction (and, to a lesser extent, chemical/pressure solution) drives a rapid evolution of the sizes and connectivity of pores and pore throats. Large pores connected by many large pore throats are characteristic of coarser, uncompacted clean sands. But small pores, connected by only one or two highly constricted pore throats, are typical of both very fine, shaly sands and of coarser but ductile-rich and compacted sandstones. Table 8 presents two sets of pore-related ternary percentages from point-count data, one related to pore size (macropores $>20$ microns across, mesopores $<20$ microns, unresolved micropores), the second to pore geometry (intergranular vs. intragranular).

Table 8. Ternary percentages related to pore system, Cook Inlet sandstones

\begin{tabular}{|c|c|c|c|c|c|c|c|}
\hline WELL & DEPTH & MacroPor & MesoPor & MicroPor & InterPor & IntraPor & MicroPor \\
\hline Swanson River 1 & 4,185 & 17 & 35.4 & 47.6 & 50.9 & 1.5 & 47.6 \\
\hline Swanson River 2 & 4,363 & 0 & 0 & 100 & 0 & 0 & 100 \\
\hline N. Cook Inlet A-2 & 4,465 & 58 & 22.1 & 20 & 75.4 & 4.6 & 20 \\
\hline N. Cook Inlet A-2 & 4,580 & 20.5 & 46.2 & 33.2 & 66.8 & 0 & 33.2 \\
\hline Trading Bay A-7 & 4,861 & 26.2 & 36.7 & 37 & 56 & 7 & 37 \\
\hline MGS St. 1 & 5,696 & 2.9 & 23.3 & 73.8 & 26.2 & 0 & 73.8 \\
\hline Trading Bay A-2 & $5,990.5$ & 25.4 & 35.2 & 39.4 & 44.9 & 15.6 & 39.4 \\
\hline Deep Creek Unit 1 & 6,100 & 22.9 & 32.4 & 44.7 & 49.5 & 5.7 & 44.7 \\
\hline Trading Bay A-2 & $6,374.5$ & 17.4 & 47.8 & 34.8 & 65.2 & 0 & 34.8 \\
\hline Trading Bay A-7 & 6,382 & 24.9 & 34 & 41.1 & 45.3 & 13.6 & 41.1 \\
\hline MGS A33-11 & $7,977.6$ & 0 & 0 & 100 & 0 & 0 & 100 \\
\hline Swanson River 1 & 8,755 & 31 & 5.2 & 63.8 & 28.4 & 7.8 & 63.8 \\
\hline Swanson River 1 & 9,230 & 42.7 & 15.2 & 42.1 & 52.4 & 5.5 & 42.1 \\
\hline MGS St. 9 & $9,614.5$ & 0 & 0 & 100 & 0 & 0 & 100 \\
\hline Trading Bay G-4 & 10,104 & 30.1 & 30.1 & 39.8 & 49.4 & 10.7 & 39.8 \\
\hline Deep Creek Unit 1 & 10,244 & 8.1 & 18.8 & 73.2 & 10.7 & 16.1 & 73.2 \\
\hline Trading Bay D-43 & 10,566 & 2.9 & 17.5 & 79.5 & 17.5 & 2.9 & 79.5 \\
\hline Swanson River 1 & 10,816 & 0 & 2.4 & 97.6 & 2.4 & 0 & 97.6 \\
\hline Granite Pt. 1 & 10,871 & 0 & 0 & 100 & 0 & 0 & 100 \\
\hline Swanson River 2 & 10,875 & 18.3 & 18.3 & 63.3 & 30.6 & 6.1 & 63.3 \\
\hline Cherryville A-15 & 11,142 & 2.9 & 5.8 & 91.4 & 5.8 & 2.9 & 91.4 \\
\hline Beluga River 1 & 11,590 & 0 & 0 & 100 & 0 & 0 & 100 \\
\hline Dolly Varden D-2 & $11,722.1$ & 0 & 0 & 100 & 0 & 0 & 100 \\
\hline Dolly Varden D-2 & 12,199 & 11.7 & 20.5 & 67.7 & 32.3 & 0 & 67.7 \\
\hline Halasko King 1-B & $13,435.5$ & 0 & 0 & 100 & 0 & 0 & 100 \\
\hline
\end{tabular}

Selected point count-based ternary percentage related to the sandstone pore system: macropores-mesopores-micropores and intergranular pores-intragranular pores-micropores. 
The pore-size ternary values are illustrated in figure 15, with samples grouped according to current burial depth.

There is a trend towards increasing microporosity with increasing core depth apparent in figure 15. Macropores are the first to be eliminated, followed eventually by mesopores. In the very deepest, most compacted (or shaliest) samples, micropores are volumetrically dominant once core depths of $11,000 \mathrm{ft}$ or more are attained. Shallow samples with unusually high proportions of microporosity are likely to have undergone significant early burial, followed by tectonic uplift (for example, MGS State 1 5,696 ft, permeability $0.178 \mathrm{md}$ ). More deeply buried samples with surprisingly high values of macroporosity (for example, TBU G-4 10,104 ft, permeability $19.5 \mathrm{md}$ ) are relatively coarse-grained, well-sorted, and quartzose, with fewer ductile grains than most of the sample population (resulting in a mechanically more rigid framework and much slower rate of porosity loss with depth).

\section{ROUTINE CORE PLUG ANALYSES}

Routine core plug measurements were carried out on samples of the petrographic study by Core Laboratories, Inc. (Aurora, CO): helium porosity; one of several alternative horizontal permeability methods (Klinkenberg-corrected when possible, absolute air permeabilities when Klinkenberg measurements were not feasible, probe permeameter measurements when no steady-state flow methods could be used); and grain density. For a few of the samples, no permeability measurement of any type was possible. Because the sample material consisted of archived core pieces, no attempt was made to measure residual fluid saturations. In a few cases it was necessary to make the porosity and grain density measurements on different core chips. Given the nature of the samples, such compromises are unavoidable, but the potential for inaccuracies and greater-than-normal measurement errors should be borne in mind. The accuracy of microdarcy-level permeability measurements by steady-state methods, particularly in dried-out clay-rich rocks, is open to question. In addition, a number of the measured grain density values are anomalously low (in the absence of significant amounts of low-density phases

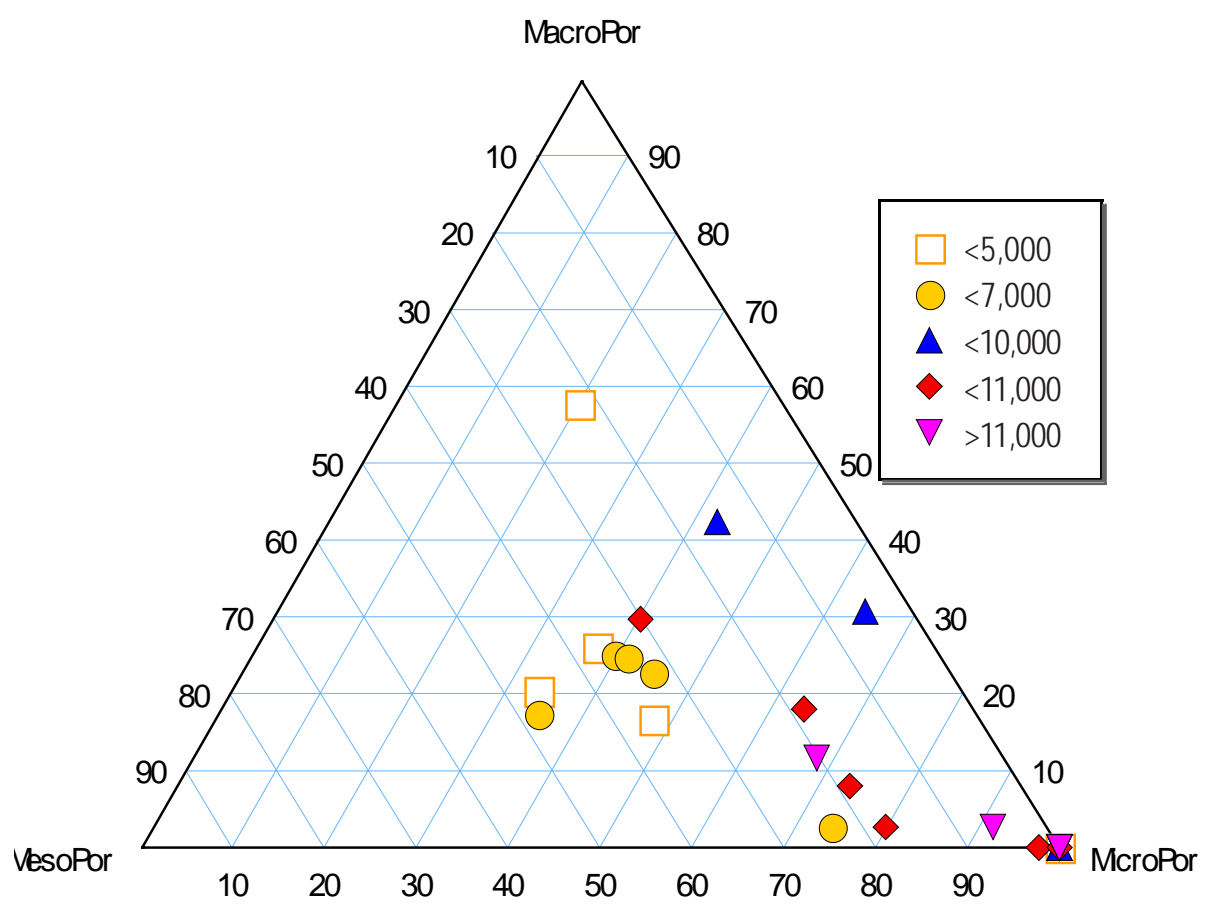

Figure 15. Macroporosity-mesoporosity-microporosity ternary diagram, grouped by core depth. Ternary diagram based on point-count data for measured (\%BV) macroporosity (visible pores with largest apparent diameter > 20 microns) and mesoporosity (visible pores less than 20 microns in diameter), and for calculated microporosity (the difference between helium porosity and thin-section porosity). There is a general tendency for increasing proportion of microporosity with depth; the anomalous microporosity-rich sample from < 7,000 ft is MGS State 15,696 ft. The micropore-poor sample from $<11,000 \mathrm{ft}$ is TBU G-4 10,104 ft. 
such as coal, residual bitumen, or zeolites), with a dozen values less than $2.63 \mathrm{~g} / \mathrm{cc}$; five of these are less than 2.60 , with a minimum value of 2.47 . These low values do not appear to be consistent with the observed mineralogy. One possible source of error could be highly irregular geometry of some of the core chips, resulting in an overestimate of sample volume. For small samples, such overestimates would result in a slight underestimate of true porosity.

Even with these caveats in mind, the routine core data overall is very consistent with petrographic observations, particularly grain size and carbonate content. A crossplot of porosity and permeability, coded by grain size (fig. 16), suggests distinct trends for different size classes, particularly at the finer end of the scale. The following regressions are obtained (fig. 17) for porosity vs. log (permeability) by size class:
Fine to Very Coarse Sand:

Log $($ PERM, md $)=0.12 *$ POROSITY $(\% B V)-1.17$ $\left(r^{2}=0.70\right)$

Very Fine Sand:

Log $($ PERM, md) = 0.086*POROSITY (\%BV) - 2.55 $\left(r^{2}=0.48\right)$

Similarly, we can obtain linear regressions of porosity vs. current burial depth (fig. 18) for the same size groupings (after excluding obvious outliers; fig. 19):

Fine to Very Coarse Sand:

POROSITY $(\% \mathrm{BV})=\mathbf{2 5 . 0}-\mathbf{0 . 0 0 1 3} *$ DEPTH $(\mathrm{ft})$ $\left(r^{2}=0.55\right)$

Very Fine Sand:

POROSITY $(\% \mathrm{BV})=27.2-0.0018 *$ DEPTH $(\mathrm{ft})$ $\left(r^{2}=0.57\right)$
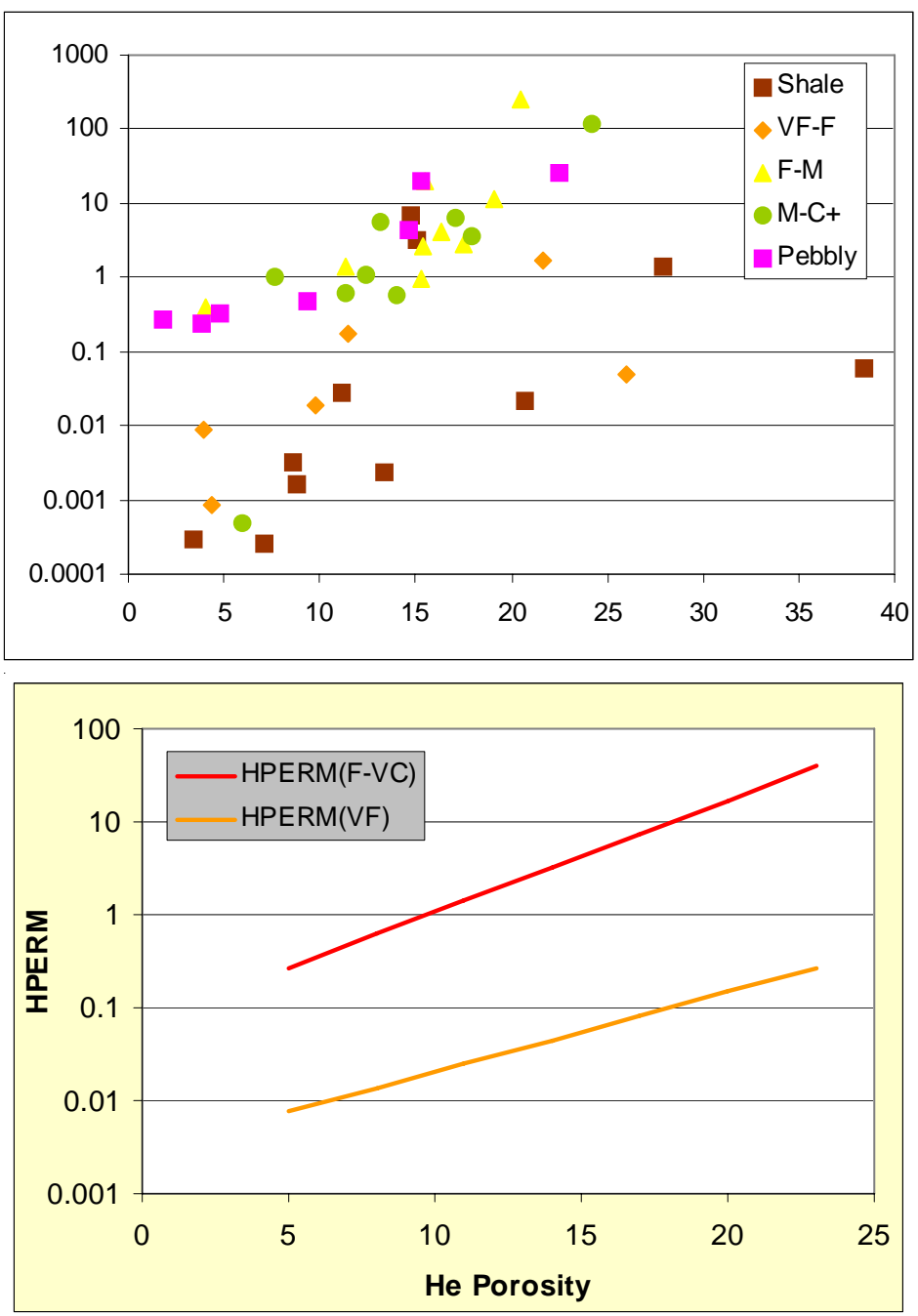

Figure 16. Porosity/permeability crossplot for all petrographic samples (except tuffs), by grain size. Semi-logarithmic plot of measured core plug porosity (horizontal axis) vs. permeability (vertical axis, log scale) for all samples (except suspected tuffs), grouped by grain size. In general, permeability is better at a given porosity as grain size increases, with larger effects in finer size classes.

Figure 17. Calculated porosity/permeability transforms for very fine and fine to very coarse sandstones. Transforms based on linear regression (log of permeability vs. porosity) of measured data for two classes of sandstones: very fine-grained and fine to very coarse-grained. 
An obvious next step is to use these two regressions in combination to calculate a nominal permeability value as a function of burial depth, thus bypassing some of the scatter and uncertainty inherent in a direct permeability/ depth regression. The results of this calculation are illustrated in figure 20. Note that throughout the depth range of interest, there is a predicted difference of about 2 orders of magnitude in the permeability of very fine sandstones and sandstones of coarser grain size. Alternatively, the depth at which the predicted permeability reaches $1 \mathrm{md}$ (the cut-off for many definitions of tight gas sandstones) is something shallower than $3,000 \mathrm{ft}$ for very fine sandstones, but nearly $12,000 \mathrm{ft}$ for fine-grained and coarser sandstones.

The preceding statistical analyses can be used as indicators of expected trends, but should not be viewed as quantitatively rigorous predictive models. The sample population is too limited in total numbers and in the range of potential depositional and burial scenarios represented; some of the core data is suspect, given the anomalously low grain densities; and the correlation coefficients for the regressions are only moderately good.
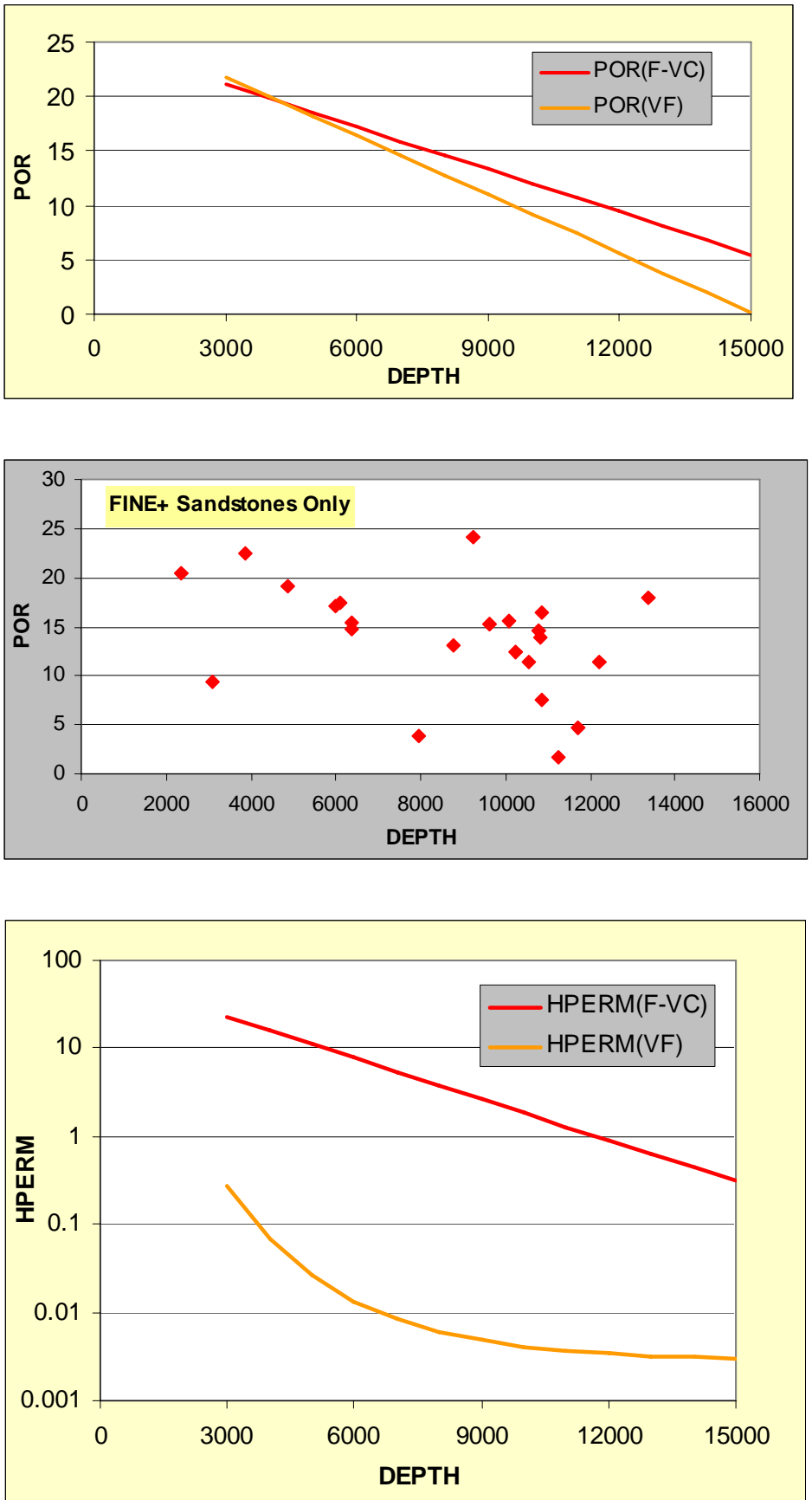

Figure 18. Linear porosity/depth trends calculated for very fine and fine to very coarse sandstones. Trend lines based on linear regression of measured core porosity vs. current burial depth for two classes of sandstones: very fine-grained (orange line) and fine to very coarse-grained (red line). Note that on average very fine sandstones lose porosity more quickly over this depth range, resulting in a difference of around 5 p.u. by $12,000 '$.

Figure 19. Core porosity vs. current burial depth for all samples of fine sand size and coarser. Measured core porosity data as a function of current burial depth for all sandstones fine-grained or coarser. Anomalously lowporosity samples at shallow depths are likely to have undergone significant uplift after their maximum burial.

Figure 20. Calculated depth trends for permeability of very fine and fine to very coarse sandstones. Depth vs. calculated permeability for sandstones of very fine (orange) or fine to very coarse (red) grain size, based on depth/porosity and porosity/permeability transforms. 
The relationships are helpful, nonetheless, for comparing the relative reservoir quality implications of different facies models or burial scenarios. As an illustration, table 9 presents the predicted properties for two sandstone bodies, each $100 \mathrm{ft}$ thick. Sand A consists of a braid bar/channel complex, containing 80 percent fine- to coarse-grained sand and 20 percent very fine-grained sand. Sand B is from a distal braid plain setting, 50 percent fine to coarse and 50 percent very fine sand. Sand A was initially buried to a maximum of $12,000 \mathrm{ft}$, but has since been uplifted to 9,000 ft. Sand B is currently at its maximum burial depth of 9,000 ft. The regressions developed above have been used to calculate a weightedaverage porosity and a total flow capacity (kh, md-ft) for the two hypothetical sand bodies.

Note the controlling effect of maximum burial depth on reservoir quality. Even though Sand A is from a more favorable facies setting, the additional 3,000 ft of burial relative to Sand $B$ more than offset the facies advantage: the more distal deposit ends up with twice the flow capacity, and half again as much storage capacity, as the more proximal sand body. In a two-fluid system (gas/water), the situation is further complicated by capillary effects, which would tend to be more favorable in the coarser-grained facies. In terms of hydrocarbon storage capacity and gas flow capacity, the differences between Sands A and B may be considerably less than illustrated in table 9. Capillary effects are discussed further in the following section.

The relative importance of grain size and burial depth to reservoir quality can be gauged by comparing the magnitude of these effects to that of pore-filling cement, as in figure 21.

\section{MERCURY INJECTION CAPILLARY PRESSURE MEASUREMENTS}

As a further step in the characterization of the pore systems of low-permeability compacted Cook Inlet sandstones, six samples were selected for mercury injection capillary pressure (MICP) analysis. Samples were selected on the basis of measured permeability, grain size, and depth distribution from among those samples that were also the subject of point counting. The actual sample material used for the tests consisted of the core plug trim ends left over after thin section preparation. Table 10 presents a list of the MICP samples, together with selected petrographic parameters.

The MICP analyses were performed by PetroTech Associates (Houston, TX). Testing consisted of injecting mercury at a series of controlled pressure steps,

Table 9. Predicted average porosity and total flow capacity for two hypothetical sand bodies

\begin{tabular}{lrrrrc}
\hline Sand & \%VF & \%F-C & Dmax & Porosity & $\begin{array}{c}\text { Flow } \\
\text { Capacity }\end{array}$ \\
A & 20 & 80 & 12,000 & 8.6 & 73 \\
B & 50 & 50 & 9,000 & 12.2 & 135 \\
\hline
\end{tabular}

Predicted average porosity (percent BV) and total flow capacity (md-ft) for two 100 ' sand bodies with the indicated mix of facies (very fine vs. fine to coarsegrained) and maximum burial depth (Dmax, feet).

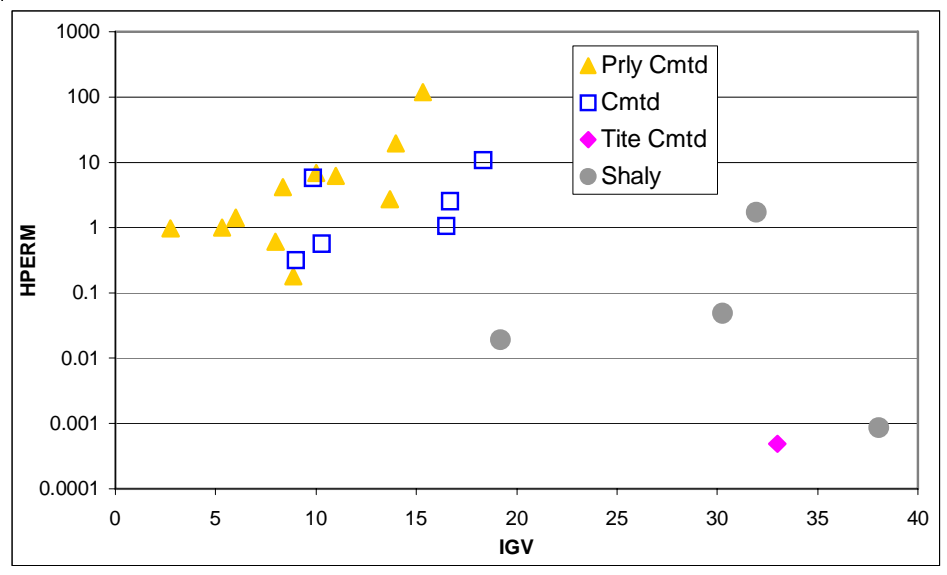

Figure 21. Intergranular volume (percent by volume) vs. horizontal permeability (millidarcies), by amount of cement. Semilogarithmic crossplot of intergranular volume (IGV, percent BV, from point-count data) and horizontal permeability (HPERM, md) for samples grouped by the amount of pore-filling cement or clay matrix they contain: Poorly Cemented = $0-5 \%$ pore-filling cement; Cemented $=5-10 \%$ cement; Tite Cemented $=$ $>20 \%$ cement; Shaly $=>10 \%$ matrix. Permeabilities for Cemented sandstones are about an order of magnitude lower than those of Poorly Cemented sands of similar IGV. 
ranging from 1.64 to 59,500 psi (fig. 22). Injected volumes were monitored at 118 steps over this pressure range; data points at the low-pressure end were corrected for conformance (intrusion due to surface irregularities). Further details on procedures and calculations are available in the written report issued by PetroTech (PA-945). The original pressure-volume data for the MICP tests are included in the "MICP" folder on the CD.

Capillary pressure tests provide a measure of the volume of porosity accessible at a given pressure in a two-phase system. Drainage tests, such as those performed here, are done under conditions of decreasing wetting phase saturations (in this case, air is the wetting phase; tests done in the opposing direction of saturation change are known as imbibition tests). When the pore system is modeled as a series of capillary tubes, higher injection pressures equate to smaller-diameter tubes: as injection pressures are increased, mercury is able to intrude into capillary tubes (or, in a more realistic view, through pore throats) of smaller diameter. It is possible to calculate the porosity of the sample based on the volume of mercury injected, and to calculate an equivalent absolute permeability based on the pressure-saturation profile. Further, by assuming a capillary tube model of the pore system, it is possible to convert the pressuresaturation profile to a distribution of pore volume accessible as a function of pore throat size, i.e., how much of the total porosity is accessible over the range of pore throat sizes present in the sample? These calculations are illustrated in table 11 and figures 23-25.

Another important set of calculated values based on the MICP data is the recasting of pressure in terms of equivalent hydrocarbon column height. Capillary pressure is the pressure differential present between two fluid phases in contact at a surface. The source of the pressure differential is the density differences between the fluids in a two-phase system. The magnitude of the surface tension at the contact opposing the pressure differential and the length scale of the interfacial area determine the stability of the system: high surface tension and/or a small radius of contact favor a stable interface. For a given pore system (modeled as a series of capillary tubes of different diameters), the capillary pressure in the air/mercury system can be recalculated

Table 10. List of samples used for MICP analyses, with selected petrographic characteristics

\begin{tabular}{lcccccc}
\hline \multicolumn{1}{c}{ Well } & Depth (feet) & Permeability & Grain size & Rigid & Ductile & Matrix \\
Beluga River 1 & 11,590 & 0.001 & VF-F & 47.2 & 22.8 & 30.1 \\
Halasko King 1B & $13,435.5$ & 0.019 & VF silty & 47.3 & 38.3 & 14.4 \\
MGS State 1 & 5,696 & 0.178 & VF-F & 74.4 & 24.4 & 1.1 \\
Swanson River Unit 1 & 10,816 & 0.566 & M-C & 46.7 & 52.5 & 0.8 \\
Trading Bay Unit A-2 & $6,374.5$ & 2.56 & F-M & 69.9 & 30.1 & 0 \\
Trading Bay A-7 & 6,382 & 6.91 & M-C & 70.4 & 29.3 & 0.4 \\
\hline
\end{tabular}

Samples used for MICP analyses, along with their measured core permeability (HPERM, md), estimated grain size (GS), and point countbased ternary percentages of rigid grains, ductile grains, and matrix. Note that the samples with the lowest permeabilities are the finest grained and have significant amounts of matrix. In the cleaner sandstones, the content of ductile grains is fairly consistent (25-30 percent normalized R-D-M values) except for the sample from SRU 1, which is relatively quite ductile-rich.

Table 11. Comparison of core and MICP estimates of porosity and permeability, and pore throat parameters

\begin{tabular}{l|cc|cc|ccc}
\hline & \multicolumn{2}{|c|}{ Core Analysis } & \multicolumn{2}{c|}{ MICP-derived } & \multicolumn{2}{c}{ Pore Throat Apertures } \\
\hline \multicolumn{1}{c|}{ Sample } & POR & HPERM & POR & HPERM & Median & $1^{\circ}$ Mode & $2^{\circ}$ Mode \\
Beluga 1 11590 & 4.4 & 0.001 & 4.71 & -- & 0.014 & 0.014 & -- \\
King 1B 13345 & 9.8 & 0.019 & 8.57 & 0.073 & 0.108 & 0.594 & 0.015 \\
MGS St. 1 5696 & 11.4 & 0.178 & 11.5 & 0.254 & 0.272 & 1.02 & -- \\
SRU 1 10816 & 14 & 0.566 & 13.9 & 1.82 & 0.055 & 3.58 & 0.015 \\
TBU A-2 6374 & 15.3 & 2.56 & 15.1 & 7.37 & 1.59 & 5.6 & -- \\
TBU A-7 6382 & 14.7 & 6.91 & 14.2 & 4.18 & 1.33 & 5.13 & -- \\
\hline
\end{tabular}

List of the routine core measurements of porosity (POR, percent BV) and permeability (HPERM, md), in the "Core Analysis" columns, compared with the porosities and permeabilities estimated from MICP data ("MICP-derived"); in general there is excellent agreement in the porosity values and good agreement between the measured and estimated permeabilities. In the "Pore Throat Apertures" columns (modelbased calculations of equivalent pore-throat diameters vs. volume of mercury intruded, in microns) are the median (50th percentile) pore throat diameter, and the modal (or for some samples, the position of both peaks in a bimodal distribution) aperture value. Most of the unimodal size distributions are quite broad, and in most cases rather skewed as well. In the ductile-rich Swanson River 1 sample, it is the smaller-aperture mode that is the dominant one. 


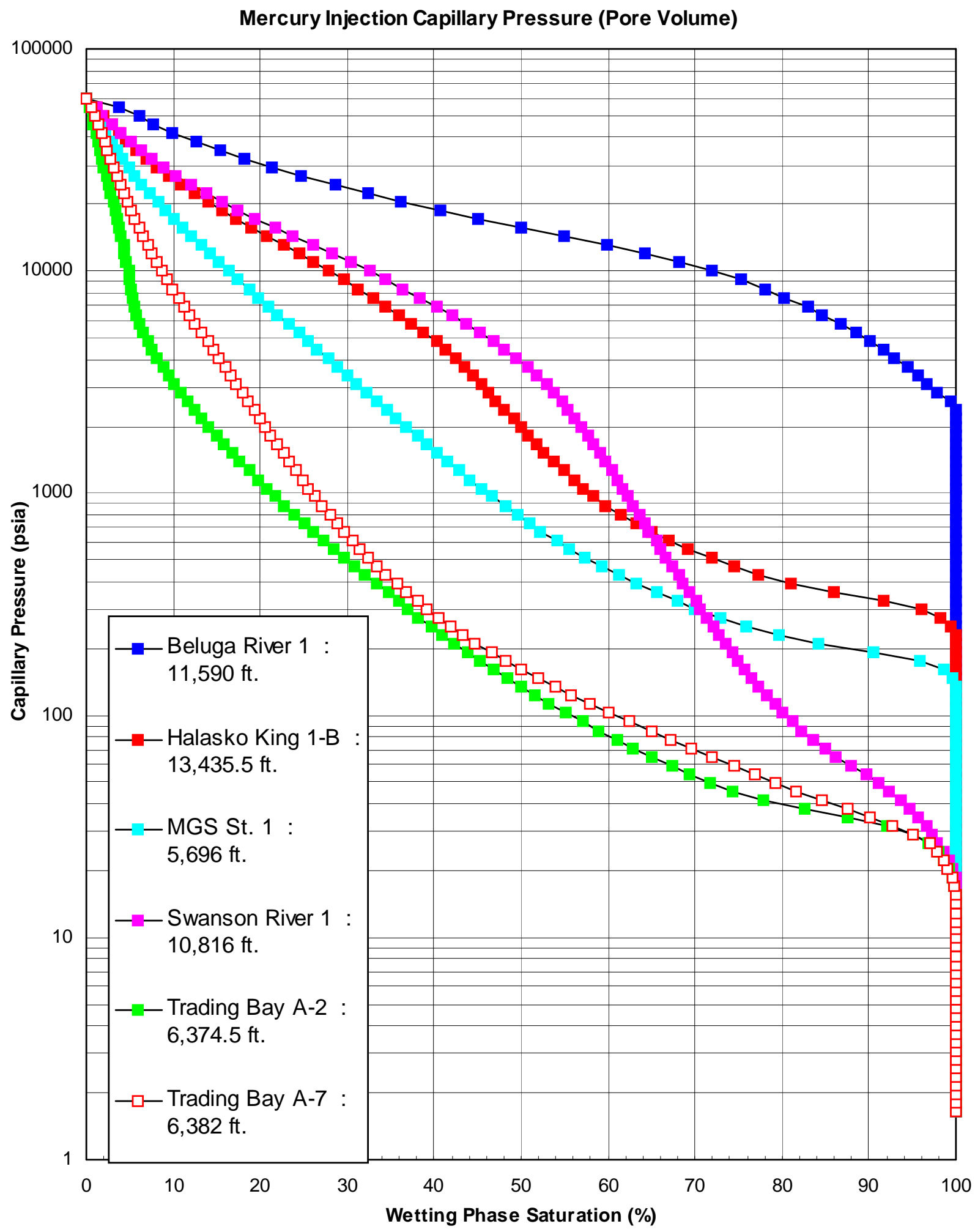

Figure 22. Mercury/air capillary pressure vs. wetting phase saturation drainage curves. Drainage curves (mercury injected, displacing air) of wetting phase saturation as a function of capillary pressure for the six selected Cook Inlet sandstone samples. Note the high entry pressures. 

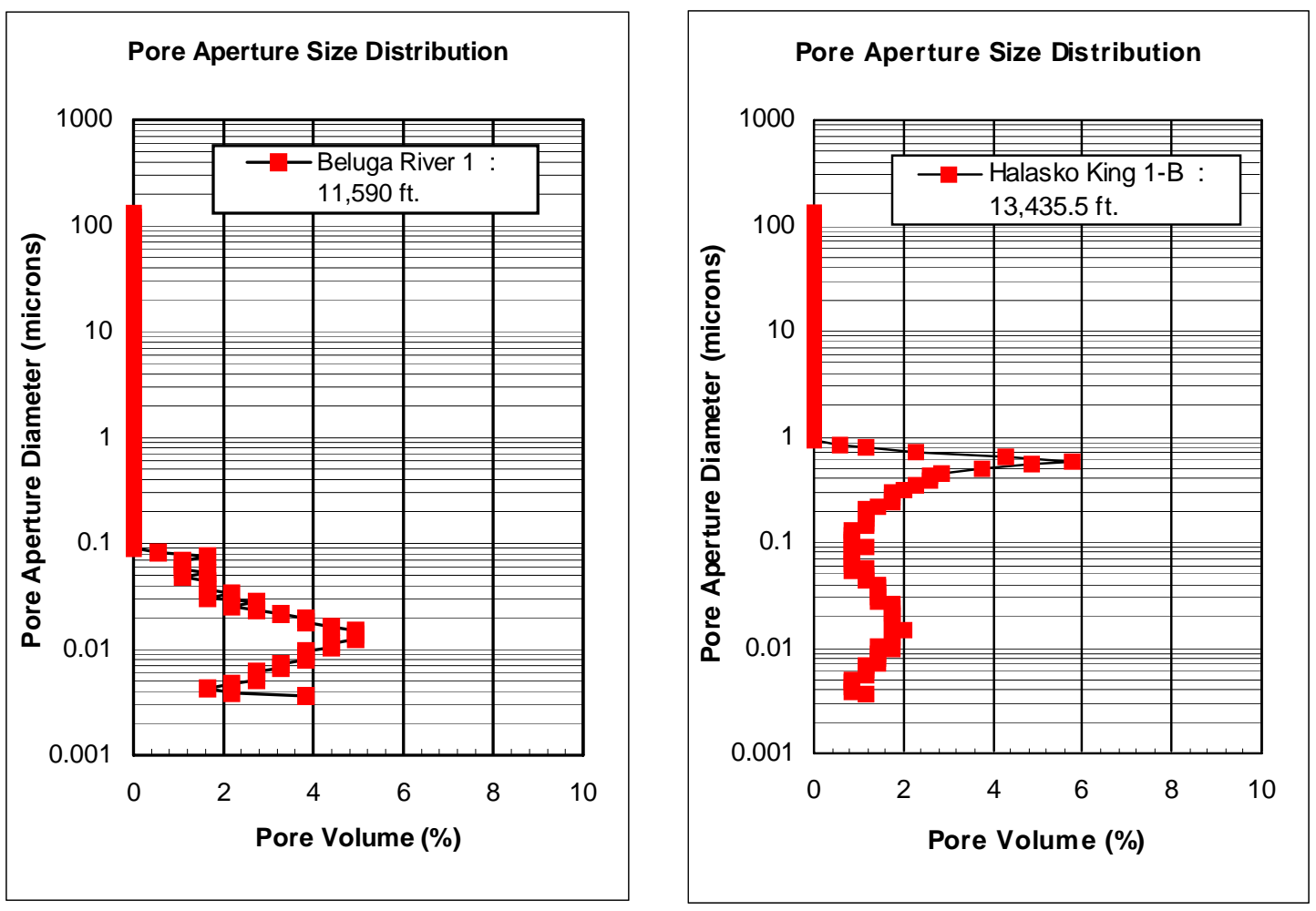

Figure 23. Distribution of calculated pore aperture sizes, Beluga River 1 11,590 ft and King 1B 13,435.5 ft. Plots of pore volume vs. nominal pore aperture diameter, in effect a pore volume-weighted distribution of pore throat sizes. Both samples are very fine-grained and shaly; measured permeabilities are $0.001 \mathrm{md}$ (Beluga River 1 11,590 ft) and 0.019 md (Halasko King 1B 13,435.5 ft).
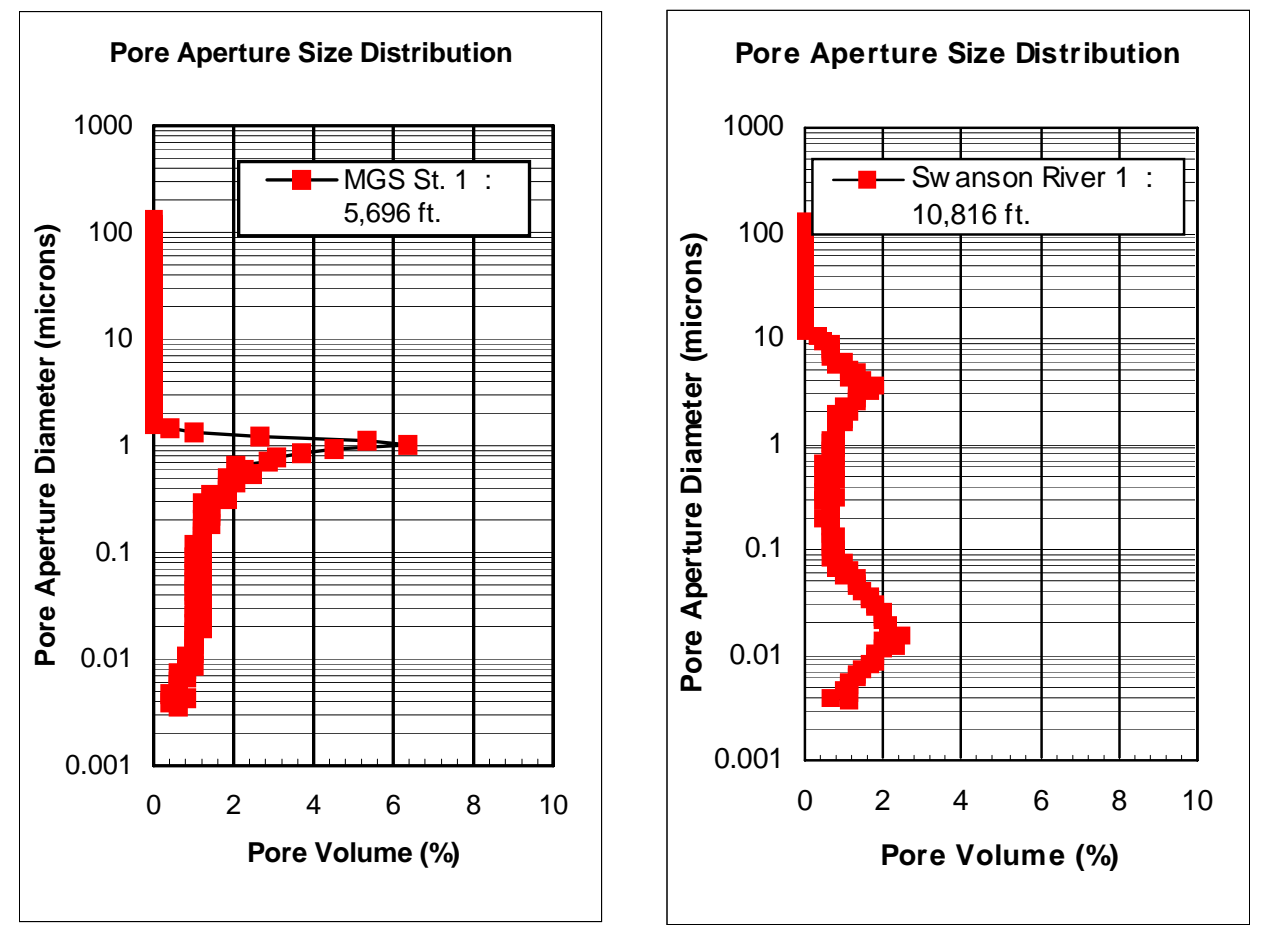

Figure 24. Distribution of calculated pore aperture sizes, MGS St. 1 5,696 ft and SRU 1 10,816 ft. Measured permeabilities are $0.178 \mathrm{md}$ (MGS St. 1 5,696 ft) and $0.566 \mathrm{md}(S R U 1$ 10,816 ft). 

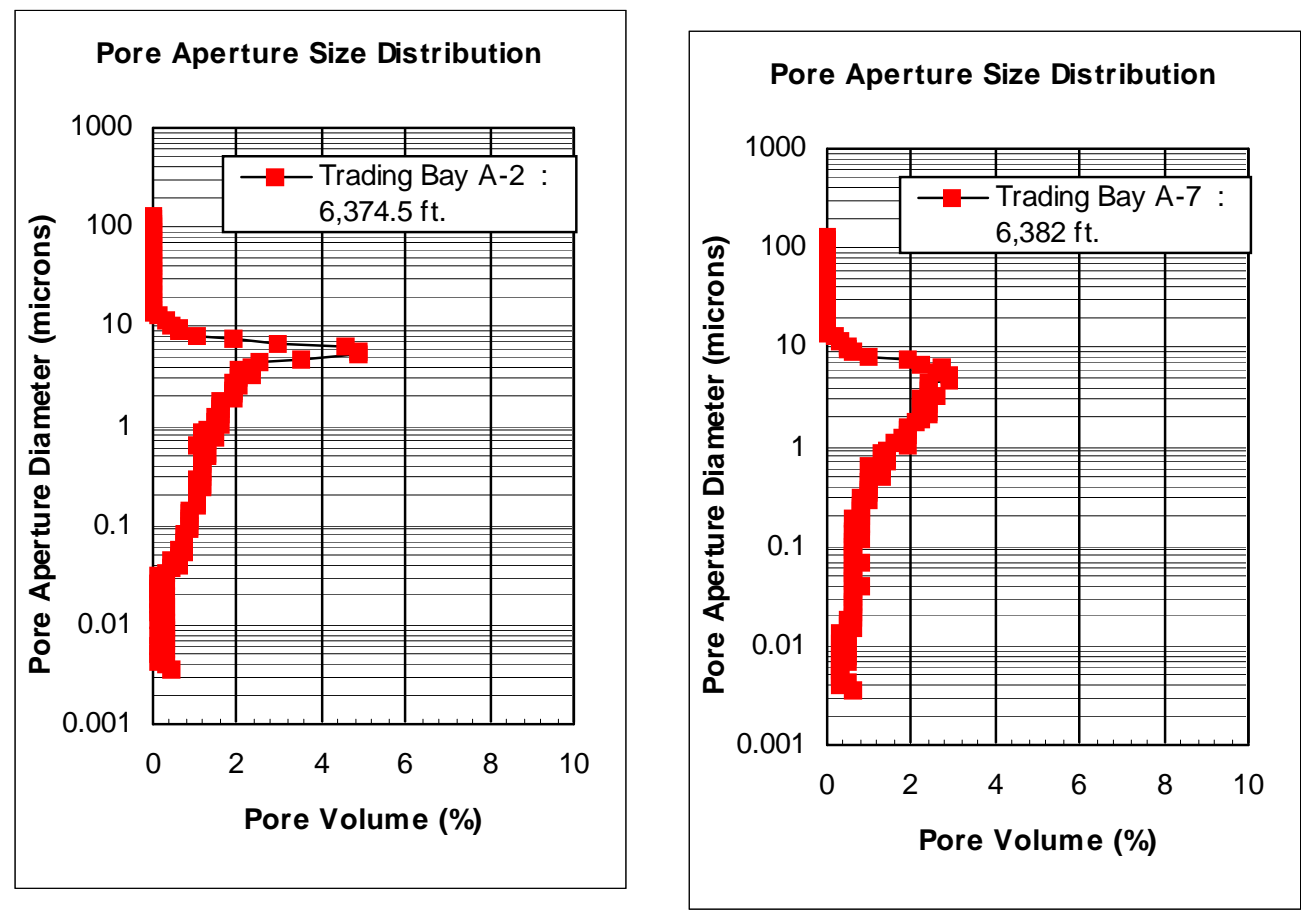

Figure 25. Distribution of calculated pore aperture sizes, TBU A-2 6,374.5 ft and TBU A-7 6,382ft.

Measured permeabilities are $2.56 \mathrm{md}$ (TBU A-2 6,374.5 ft) and $0.566 \mathrm{md}$ (TBU A-7 6,382 ft).

as the equivalent column height in a gas/water system, given estimates of the densities and surface tension for the fluids involved, as indicated in the following equations, which convert mercury/air capillary pressure to gas/brine capillary pressure, then convert that pressure to column height:

$$
\mathrm{Pc}_{\text {gas-brine }}=\mathrm{PcH}_{\mathrm{g} \text {-air }} *\left(\sigma^{*} \operatorname{Cos} \theta\right)_{\text {gas-brine }} /\left(\sigma^{*} \operatorname{Cos} \theta\right) \mathrm{Hg} \text {-air }
$$

$$
\text { Height above FWL }=\text { Pc } /\left(0.433 *\left(\rho_{\text {brine }}-\rho_{\text {gas }}\right)\right)
$$

where Pc is capillary pressure of the indicated two-phase fluid system, $\sigma$ is surface tension, $\theta$ is the contact angle (reflecting wettability), and $\rho$ is the density of the indicated phase.

These calculations have been carried out for these analyses, using the following estimates of fluid properties in table 12.

The resulting water saturation profiles are illustrated in figure 22, using the same MICP data as figure 26, but changing the pressure scale to estimated equivalent height above the free water level (FWL). Note that, given the gradual slope of these curves, the gas/water contact in these sandstones would not be a sharply-defined interface, but rather a transition zone of incrementally increasing gas saturation.

Other useful parameters that can be estimated from MICP data include the entry pressure for gas (the minimum capillary pressure required to allow migrating gas to overcome the surface tension of resident pore fluids and begin to fill a trap) and the "irreducible water saturation" ( $\mathrm{S}_{\mathrm{w}}$ irr $)$, the minimum wetting-phase saturation achieved in a hydrocarbon column of a particular height. Estimated entry pressures and irreducible saturations (for an assumed gas column of $400 \mathrm{ft}$ ) for the six samples analyzed in this study, expressed as the height in feet above the free water level in a gas/water system, are listed table 13.

A regression of $\log$ (permeability) against $S_{w}$ irr $(400)$ yields the following equation:

$$
\mathrm{S}_{\mathrm{w}}^{\text {irr }}(400)=38.5-18.4 * \log (\text { PERM })
$$

with a correlation coefficient $\left(\mathrm{r}^{2}\right)$ of 0.83 . A reservoir sandstone with 1 md permeability would be expected to have a water saturation of just under 40 percent at the top of a $400 \mathrm{ft}$ gas-filled structure; a $10 \mathrm{md}$ sandstone would have a water saturation of about 20 percent.

Applying this correlation to the hypothetical case of two sandstone bodies of contrasting facies (table 9), the storage capacities, in terms of hydrocarbons rather than total fluids, would have to be discounted as shown in table 14.

A straight-up comparison of very fine vs. fine to coarse sands with a maximum burial depth of 9,000 ft indicates a significant difference in the expected hydrocarbon-filled pore volume (HCPV), based on the 
Table 12. Contact angle and surface tension values for mer-

cury-air and gas-brine capillary systems

\begin{tabular}{lcc} 
System & $\theta$ & $\sigma$ \\
Hg-air & $0 \mathrm{o}$ & 72 \\
Gas-brine & $140 \mathrm{o}$ & 480 \\
\hline
\end{tabular}

Table of contact angle (è, degrees) and surface tension (ó) values used for conversion of mercury-air to gas-brine capillary pressures. This converted pressure was then restated as a height above free water level using estimated densities of $1.19 \mathrm{~g} / \mathrm{cc}$ for the brine and 0.08 $\mathrm{g} / \mathrm{cc}$ for the gas.

Table 13. Estimated entry pressures (in feet, Gas/Water system) and water saturations at 400' above free water line (FWL)

$\begin{array}{ccccc}\text { Well } & \text { Depth } & \text { Permeability } & \text { Entry Pressure } & \mathbf{S}_{\mathbf{w}}^{\text {irr }} \mathbf{( 4 0 0 )} \\ \text { GS State 1 } & 5,696 & 0.178 & 70 & 46 \\ \text { Tading Bay A-2 } & 6,374.5 & 2.56 & 10 & 21 \\ \text { Trading Bay A-7 } & 6,382 & 6.91 & 10 & 26 \\ \text { wanson River 1 } & 10,816 & 0.566 & 10 & 62 \\ \text { eluga River 1 } & 11,590 & 0.001 & 1,000 & 100 \\ \text { alasko King 1B } & 13,435.5 & 0.019 & 120 & 58\end{array}$

Measured plug permeabilities (millidarcies), estimated capillary entry pressures (expressed as feet above free water line in a gas/water system), and estimated irreducible water saturations (for a nominal 400 foot gas column) for the six MICP samples.

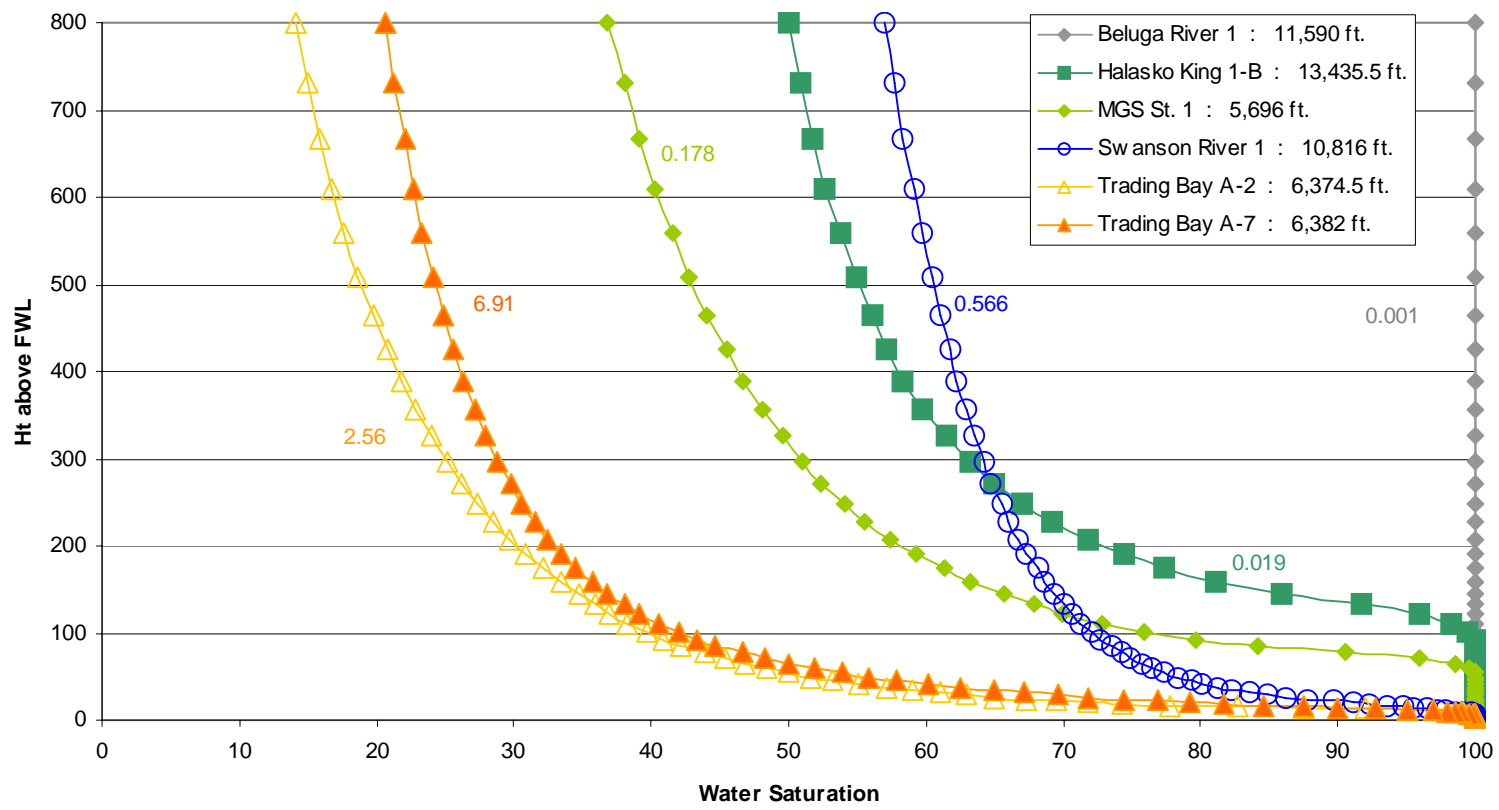

Figure 26. Water saturation vs. height above free water level in a gas/water system, based on MICP data. Calculated water saturation vertical profiles, as a function of height ( $\mathrm{ft}$ ) above the free water level, for Cook Inlet MICP samples. Numbers next to each sample's saturation curve is the measured core permeability (md) for that sample. Note the wide range in estimated $S_{w}$ at various heights within a reservoir, e.g., $400 \mathrm{ft}$ (the nominal $S_{w}{ }^{\text {irr }}$ used in this report) 
Table 14. Comparison of total and hydrocarbon-filled average pore volume for two model sand bodies

\begin{tabular}{ccccc} 
Sand & $\begin{array}{c}\text { Percent very } \\
\text { fine sand }\end{array}$ & $\begin{array}{c}\text { Percent fine to } \\
\text { coarse sand }\end{array}$ & $\begin{array}{c}\text { Total pore } \\
\text { volume }\end{array}$ & $\begin{array}{c}\text { Hydrocarbon- } \\
\text { filled porosity }\end{array}$ \\
A & 20 & 80 & 8.6 & 4.6 \\
B & 50 & 50 & 12.2 & 6.2 \\
\hline
\end{tabular}

Comparison of calculated average porosity (Total PV, or pore volume, percent by volume) and hydrocarbon-filled porosity (HCPV, hydrocarbon pore volume, percent by volume) for two hypothetical sandstone bodies. Sand A has a higher proportion of fine- to coarse-grained sandstone, but has been buried more deeply (12,000 ft rather than 9,000 ft for Sand B). The increased compaction suffered by Sand A more than offsets the advantage of more favorable facies development. In both cases, the weighted average water saturation at 400 volume above FWL is just less than 50 percent.

correlations developed in this study: HCPV would be 9.2 percent in the fine to coarse sand, and only 3.5 percent in the very fine sand. In less pronounced structural closures (relative to the $400 \mathrm{ft}$ assumed here), estimated water saturations would be much higher, the contrast in HCPV between facies considerably smaller.

\section{SHALES AND TUFFS}

A number of the samples collected for this study do not represent conventional reservoir rock types. These samples range from silty shales to vitric-crystal tuffs. Several examples of pebble conglomerates have been sampled as well. Although such pebbly deposits are a common feature of many fluvial reservoirs, they tend to be volumetrically minor, and in any case cannot be adequately characterized by samples of standard thin section size. Table 15 is a list of the "unconventional" samples in this study, along with a summary of petrographic properties; further comments on the samples are included in table 16.

Most of the shales are quite silty and/or sandy, poorly to moderately sorted, micaceous and slightly lignitic, with a disturbed or mottled fabric (in some cases apparently burrowed). Despite the low measured permeabilities of most of the silty shale samples, these rocks would not represent very good seals for conventional gas reservoirs; further study of the sealing capacity and distribution of potential seals for tight gas sandstone reservoirs would be a valuable tool for estimating the stratigraphic occurrence and maximum likely size of such reservoirs. Some of the shales are quite silt-poor and porous (North Cook Inlet A-2 4,815 ft, interpreted as a possible bentonite), or pebbly, porous, and very heterogeneous (Wasilla State). Most of the samples from the Wasilla St. 1 well are problematic, consisting either of pebbly shales that resemble hardened mudcake, or primary volcanic rocks in the form of altered vitric-crystal tuffs. Two samples from the central area (MGS A33-11 8,607.5 ft and Trading Bay D-43 10,795 ft) are clast-supported pebble conglomerates with bimodal sorting, a compacted sand matrix, and extensive authigenic clay (smectite or kaolinite). Such samples make it clear that even the coarsest facies can achieve very low permeabilities via compaction and pore-filling clays.

\section{DISCUSSION \\ PROVENANCE}

The provenance of these sandstones is a variable mixture of three major extrabasinal source terranes: granitic crystalline basement, active and reworked volcanic complexes (predominantly of dacitic to andesitic composition), and a terrane of primarily low to medium-grade metasedimentary rocks. Intrabasinal detritus (mostly ripup clasts) is generally negligible. The crystalline basement and volcanic terranes are inferred to represent the contributions of a nearby active but locally dissected volcanic arc. These igneous clasts may have been derived from the Alaska Range. The metasedimentary terrane may represent material from the Chugach accretionary wedge outboard of the volcanic arc, but may include a small component derived from the wallrock of the arc itself. Table 17 presents a generalized interpretation of the ultimate source of most of the important detrital grain types in our sample sandstones. For individual mineral grains (such as quartz and plagioclase feldspar), there is bound to be some ambiguity as to their origin, and a more statistically valid study and classification would be required to categorize all such grains with any confidence.

A series of ternary plots (figs. 27-29) are presented to illustrate the compositional range and possible geographic and stratigraphic trends in sand detrital composition. In most cases, stratigraphic age appears to be a more important factor than geography. This suggests that, although the Cook Inlet Basin is an elongate forearc basin (fig. 2) apparently dominated by two major source terranes (Alaska Range arc, Chugach terrane accretionary wedge), basin fill was not directly from the adjacent source areas laterally into the basin. Instead, it was primarily by axial transport down the length of the 


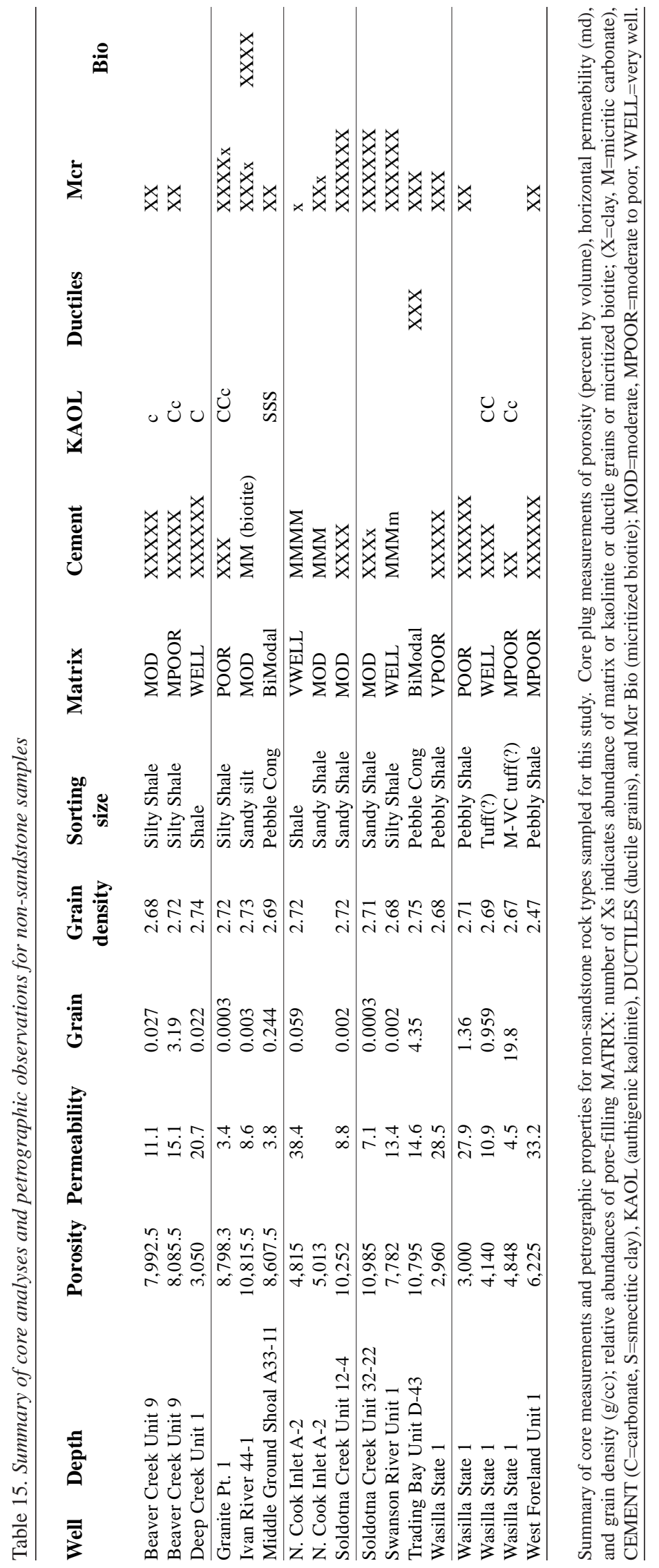


basin, with some degree of mixing en route, but typically dominated by a dissected arc, an active volcanic arc, an accretionary wedge, or, for the early Tertiary section, a source terrane north of the proto Alaska Range.

The QtFL (fig. 27) and QmFLt (fig. 28) ternary plots are useful in that they incorporate most of the detrital grain population (unlike several more specialized plots), but tend to be less discriminating and more subject to grain size bias as a result. Ternary plots of more narrowly defined end-member grain types (fig. 29) commonly give more specific information about provenance; the major drawback of such specialized plots is that, in many samples, the grain types being illustrated are rare enough that the results of normalizing the point count data are not statistically robust, and may be misleading. For the samples in this study, however, this does not represent a major problem, due to their relatively lithic-rich nature.

In most of the plots above, both age and location appear to play a role in defining the detrital composition of the sandstones. The oldest sandstones (Hemlock,
Hemlock?) are relatively enriched in metasedimentary and/or volcanic rock fragments, with some apparent geographic segregation: sandstones from the central area tend to have more metasedimentary grains, those from the east and north more volcanics. Most of the Tyonekage sandstones from the eastern area are enriched in volcanic fragments and chert, whereas those from the central area include both chert-poor and chert-rich examples. Geographic diversity appears to decrease over time. Sandstones of inferred Beluga(?) age are all distinctly enriched in metasedimentary fragments, and relatively feldspar-poor. During Sterling time, sandstone composition returns to a volcanic- and/or chert-rich variety. Making due allowance for the geographic diversity exhibited in the older units (the result of young, poorly integrated drainage systems and tectonic relief?), there appear to be at least two cycles of sand compositional evolution: Hemlock sandstones dominated by metasedimentary detritus give way to more volcanic-rich Tyonek sandstones; these in turn are followed by Beluga sandstones with abundant metasedimentary grains, capped

Table 16. Additional notes on non-sandstone samples

\begin{tabular}{|c|c|c|}
\hline Well & Depth & Notes \\
\hline Beaver Creek 9 & $7,992.5$ & Silty, slightly lignitic shale, burrowed(?), slightly micaceous \\
\hline Beaver Creek 9 & $8,085.5$ & $\begin{array}{l}\text { Silty shale; sandy, slightly lignitic shale, irregular silty lenses, } \\
\text { microcrystalline siderite(?), recycled coal(?) }\end{array}$ \\
\hline Deep Creek Unit 1 & 3,050 & $\begin{array}{l}\text { Illitic shale, sparse quartz silt and very fine sand, mottled extinction } \\
\text { pattern; sphaerosiderite(?) }\end{array}$ \\
\hline Granite Pt. 1 & 8,798.3 & $\begin{array}{l}\text { Micritized silty, sandy, micaceous lignitic shale with minor sandstone } \\
\text { laminations }\end{array}$ \\
\hline Ivan River 44-1 & $10,815.5$ & $\begin{array}{l}\text { Sandy silt with abundant micritized biotite, common charcoal flakes; } \\
\text { compacted, minor small pores in sandy laminations }\end{array}$ \\
\hline MGS A33-11 & $8,607.5$ & $\begin{array}{l}\text { Clast-supported sandy pebble conglomerate; extensive PF smectite(?); } \\
\text { compacted, fractured grains; radiolarian chert, tuffs }\end{array}$ \\
\hline N. Cook Inlet A-2 & 4,815 & $\begin{array}{l}\text { Highly microporous, shale, silty micritic clay-poor shale (altered ash?); } \\
\text { small mica flakes, rare sand grains }\end{array}$ \\
\hline N. Cook Inlet A-2 & 5,013 & Microporous lignitic silty and sandy micritic altered ash(?) \\
\hline Soldotna Ck. 12-4 & 10,252 & $\begin{array}{l}\text { Highly micaceous silty shale with common millimeter-scale sandstone } \\
\text { laminations and lenses (lignitic, micaceous; very low porosity) }\end{array}$ \\
\hline Soldotna Ck. 32-22 & 10,985 & $\begin{array}{l}\text { Micaceous silty, slightly sandy shale with } 3 \mathrm{~mm} \text { bed of very fine silty } \\
\text { micaceous sandstone, minor small pores }\end{array}$ \\
\hline Swanson River 1 & 7,782 & $\begin{array}{l}\text { Highly lignitic silty shale, common thin silt laminations, lenses; lignitic } \\
\text { drapes on starved silt ripples }\end{array}$ \\
\hline Trading Bay D-43 & 10,795 & $\begin{array}{l}\text { Clast-supported sandy pebble conglomerate; common kaolinite; } \\
\text { volcanic-rich clast suite; close-packed sand matrix }\end{array}$ \\
\hline Wasilla St. 1 & 2,960 & $\begin{array}{l}\text { Silty shale matrix; very fine arkosic micaceous sandstone, silty shale, } \\
\text { chert, coal? }\end{array}$ \\
\hline Wasilla St. 1 & 3,000 & $\begin{array}{l}\text { Sparse sand grains, shale, and silt clasts in clay matrix; possible } \\
\text { mudstone }\end{array}$ \\
\hline Wasilla St. 1 & 4,140 & $\begin{array}{l}\text { Crystalline quartz-plagioclase vein-fill; quartz, euhedral plagioclase } \\
\text { crystals, calcite needles in altered matrix }\end{array}$ \\
\hline Wasilla St. 1 & 4,848 & $\begin{array}{l}\text { Plagioclase-rich crystal-lithic andesitic tuff; slightly reworked; calcite, } \\
\text { pyrite-laumontite(?) nodules; altered; common }\end{array}$ \\
\hline West Foreland 1 & 6,225 & $\begin{array}{l}\text { Coal, lignitic shale, quartzite, metamorphic (?) clasts floating in silty } \\
\text { slightly lignitic shale matrix: possible mudstone }\end{array}$ \\
\hline
\end{tabular}


by renewed volcanogenic sedimentation of the Sterling Formation. The changes in dominant sediment source, switching back and forth between a volcanic and plutonic arc and an accretionary wedge, may be a reflection of several possible factors: episodic volcanic activity, an evolving drainage system, differential tectonic uplift, or some combination of these. In terms of Dickinson tectonic petrofacies (Dickinson and others, 1983), the provenance of Cook Inlet Tertiary sandstones is an evolv- ing mixture of dissected volcanic arc and recycled orogen.

\section{RESERVOIR QUALITY}

The reservoir quality of Cook Inlet Tertiary sandstones is determined primarily by the effects of mechanical compaction on the pore system. In more deeply buried sandstones (limited evidence from this study suggests a threshold core sample depth on the or-

Table 17. Inferred source terranes for major detrital grain types

Sand Grain Types

Monocrystalline quartz,

polycrystalline quartz,

potassium feldspar,

muscovite, biotite; stable

heavy minerals, epidote

Volcanic rock fragments, glass

shards, plagioclase feldspar

Chert, metasedimentary rock

fragments; (quartz)

\section{Lithology}

Granitic plutonics, gneisses

Silicic to mafic, extrusive to hypabyssal volcanics

Older marine sedimentary rocks subject to minor to moderate burial metamorphism
Source Terrane

Dissected arc

(Alaska Range?)

(Talkeetna Mtns.?)

(Wrangell Mtns.?)

Active volcanic arc

(Alaska Range?)

(Wrangell Mtns.?)

Accretionary wedge

(Chugach terrane?)

(Talkeetna Mtns.?)

Generalized source rock types and locations for major detrital grain types in Cook Inlet sandstones. Some grains (for example, quartz, plagioclase) may have several possible sources, although in the coarser grain sizes the igneous sources are more likely than the metasedimentary one.

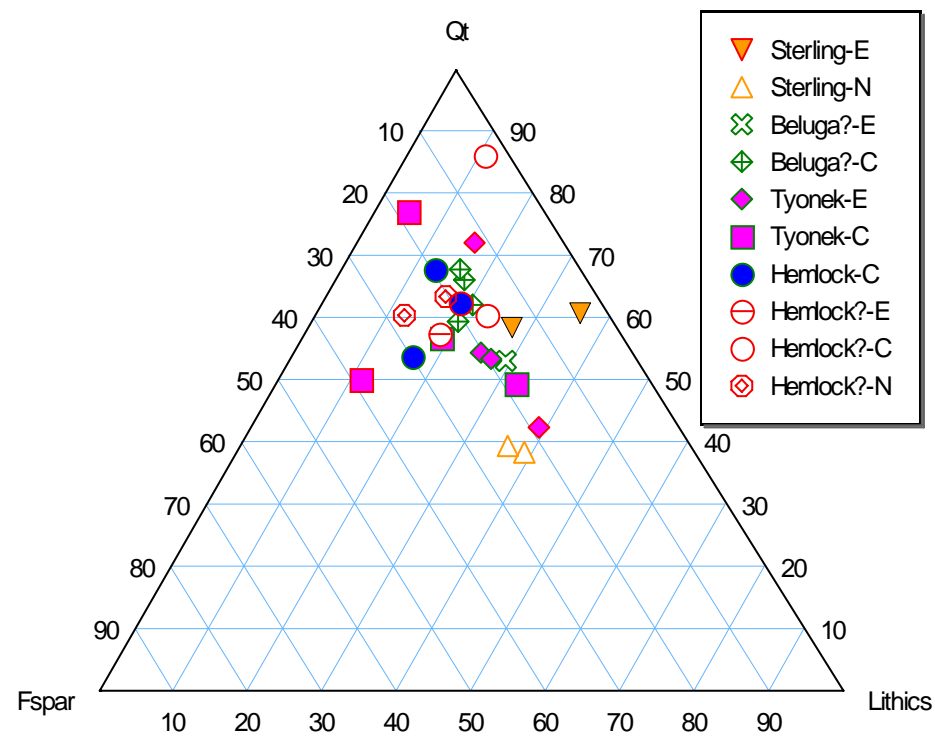

Figure 27. Total quartz-feldspar-lithics, grouped by estimated stratigraphic age and location. Total quartz (Qt, monocrystalline and polycrystalline quartz plus chert)-Feldspar (plagioclase plus alkali)Lithics (all non-chert lithic fragments) by geographic area and estimated stratigraphic unit: Sterling, Beluga, Tyonek, and Hemlock ("Hemlock?" probably includes some lower Tyonek). Most of the samples fall within the Recycled Orogenic petrofacies field of Dickinson and others (1983). 
der of $8,000 \mathrm{ft}$ ), authigenic pore-filling cements start to become volumetrically important, although the impact of such cements on reservoir quality continues to be subordinate to that of ongoing compaction. Extensive early carbonate cement does occur in a few sandstones, resulting in extremely low permeabilities, but such sandstones are likely to be relatively minor at the reservoir scale. These calcareous tight streaks may constitute important elements for reservoir architecture, but in most cases would not be common enough to affect average reservoir properties. Small amounts of irregularly distributed pore-filling cement do appear to have a modest impact on permeability (fig. 21).

The impact of mechanical compaction on sandstone reservoir quality is a function of three primary variables: maximum effective stress (in most cases, corresponding to maximum burial depth), sand texture (grain size, sorting), and sand composition (in terms of the relative proportions of rigid and ductile grain types). Based on the interpretation of depth trends of intergranular volume (fig. 11), discrepancies between current and apparent maximum burial depths on the order of 3,000-4,000 ft (and in many cases more) are not uncommon. So current core depth parameters may be a poor proxy for the maximum effective stress experienced by a potential reservoir. Large features with significant structural closure, as are commonly developed in a transpressional tectonic setting, are especially prone to major uplift and erosion. The primary distinction in terms of sand texture appears to be between sandstones that are very fine grained and those that are coarser grained (fine to slightly pebbly). The range of ductile grain types and content represented in this study's sample population does not appear to define any clear trends (fig. 10). In the absence of more detailed local data, it is reasonable to assume a generic behavior trend with increasing burial (e.g., fig. 11); more refined predictions of the amount and types of ductile grains in a particular reservoir target are neither required nor necessary, given the magnitude of the uncertainties involved in the other primary controls.

A reservoir quality issue common to most tight gas sandstones is the question of hydrocarbon charge. MICP measurements suggest entry pressures equivalent to a gas column of 10-100 ft for the lower-permeability sandstones. In practice, there appear to be two common ways to sidestep this dilemma: (1) Gas charging may predate the decline of permeability (and capillary properties) to current levels, the gas in effect being trapped in place while the pore system collapses around it; or (2) rather than having gas migrate from a source bed into a reservoir, source and reservoir are intimately interbedded. This interbedded model for biogenic source and reservoir is important for much of Cook Inlet. Primary migration of gas from the source beds (in this case, most likely coals) charges the reservoir. Early maturation and charging prior to burial and compaction (approach \#1, above) seems very unlikely in this setting. Approach \#2 is much more in keeping with the geologic situation in Cook Inlet, where coal seams are well developed at particular stratigraphic horizons in association with fluvial sandstones.

A related problem is that of potential reservoir seals. Although investigation of seal rock types is beyond the scope of this study, a number of shales were examined in thin section and measured for porosity and permeability. Median absolute permeabilities for shales are on the order of $0.01 \mathrm{md}$, similar to many of the tighter, shalier sandstones investigated (table 11). If the correlation between Swirr and permeability were to be applied to the silty shales in the overall sample suite, the expected water saturation would be about 75 percent at $400 \mathrm{ft}$ above FWL, far below that required for an effective seal.

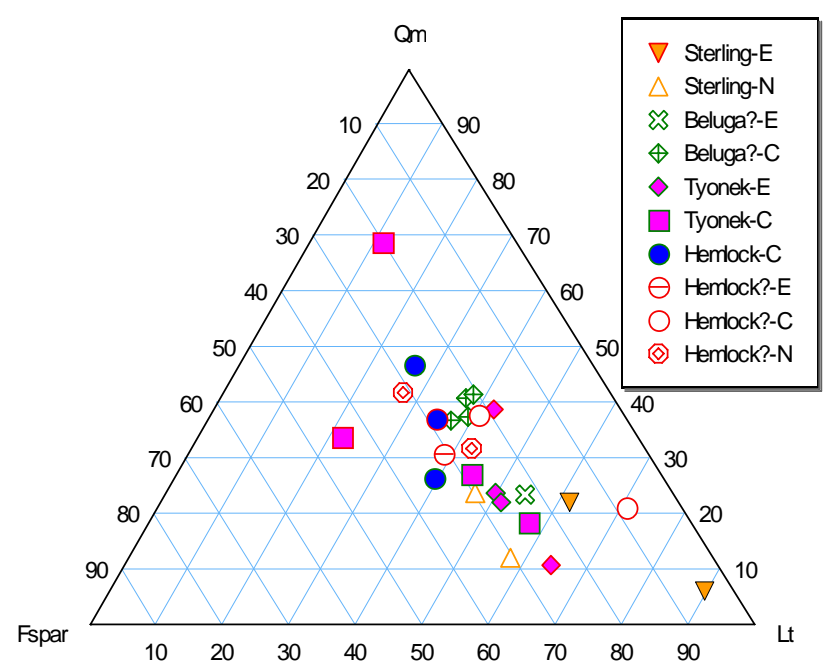

Figure 28. Monocrystalline quartz-feldspars-total lithics ternary plot, by age and location. Ternary plot of monocrystalline quartz (Qm), feldspars (plagioclase and alkali), and total lithics (all multicrystalline grains, including chert and polycrystalline quartz), grouped by geographic area ( $N=$ northern, $C=$ central, E=eastern) and inferred stratigraphic age (Sterling, Beluga, Tyonek, and Hemlock) 


\section{FORMATION EVALUATION ISSUES}

The recognition of pay in low-permeability sandstones is a serious problem in many tight gas reservoirs. Porosities are typically low, muting the effects of gas on seismic and wireline log responses. Irreducible water saturations can be quite high, masking the presence of producible gas. The presence of pore-lining authigenic clays (as in Swanson River \#1 10,816 ft) can further complicate matters by controlling the electrical properties of the sandstone. An additional complexity is intraformational water salinity variation. The following issues are of particular importance to the evaluation of gas reservoirs in low-permeability sandstones of the Cook Inlet Tertiary.

Tertiary sandstones in Cook Inlet may be feldspathic, lithic, and/or micaceous. Sandstone matrix densities can be quite variable, depending on the relative mixture of low-density (alkali feldspars, volcanic glass, coaly organic matter, zeolite cement) and high-density (micas, carbonate cement, biotite-replacing siderite, heavy minerals, mafic volcanic fragments and higher-grade metasedimentary fragments) grain types present. As a result, density log porosities have inevitably greater uncertainties (as do higher-order parameters that are

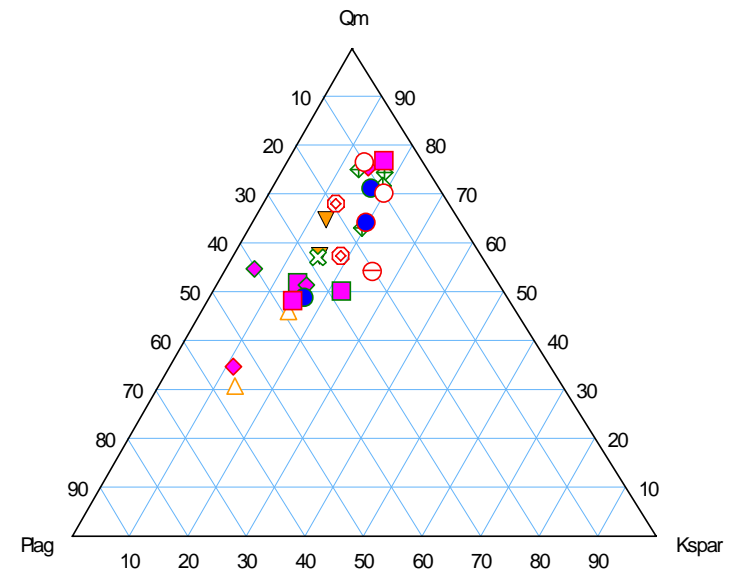

(a) Qm - Plag - K-feldspar

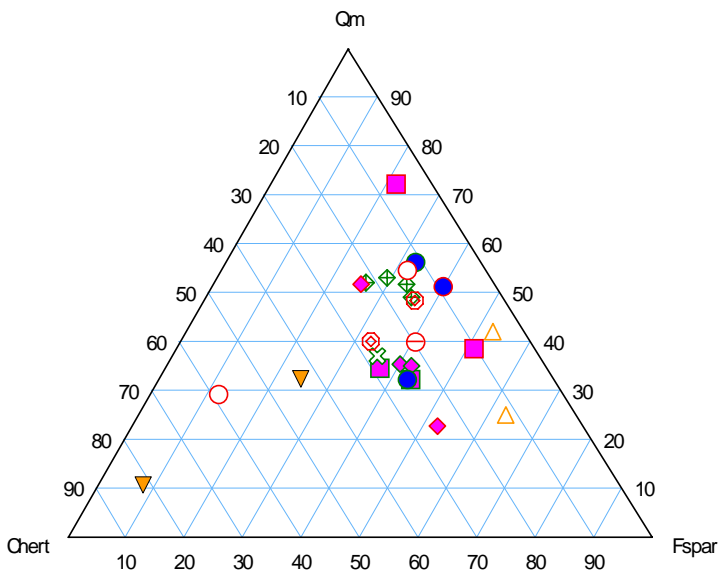

(c) Qm - Chert - Feldspar

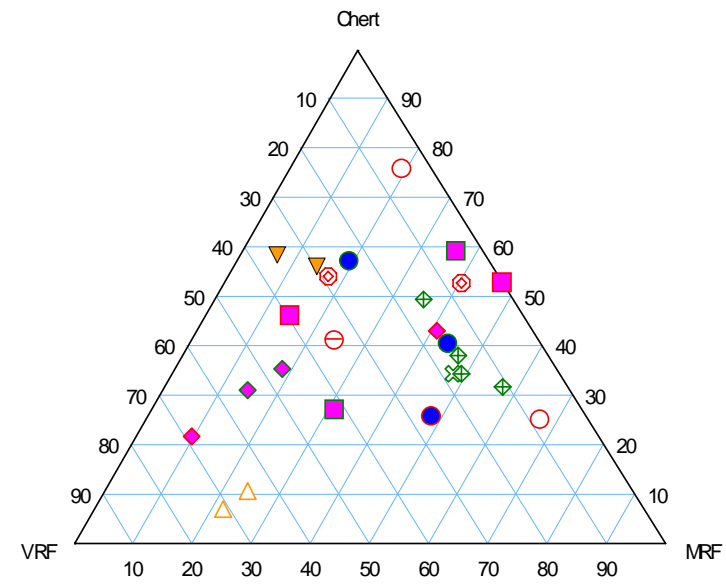

(b) Chert - VRF - MRF

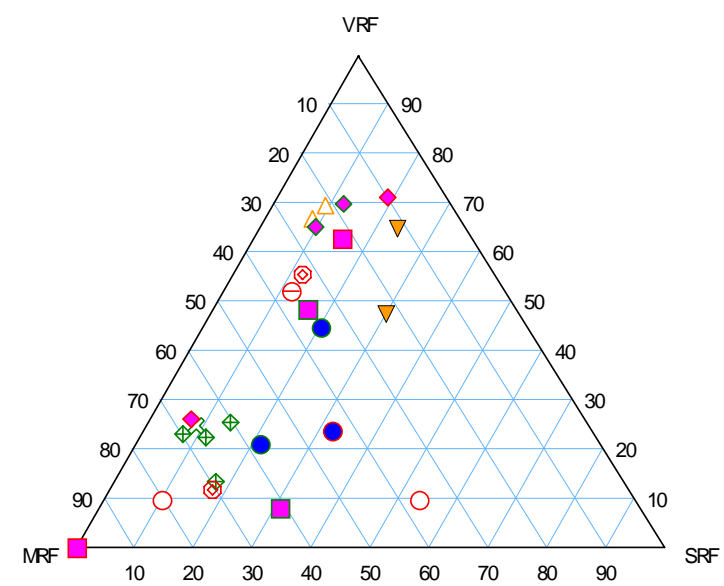

(d) VRF - MRF - SRF

Figure 29. Ternary plots of selected detrital components, grouped by stratigraphic age and location. Ternary plots of all pointcount samples for selected major detrital components, grouped by stratigraphic age and geographic location (see figure 28 for explanation of symbols):

(a) Monocrystalline quartz-Plagioclase feldspar-Potassium feldspar

(b) Chert-Volcanic rock fragments-Metamorphic rock fragments

(c) Monocrystalline quartz-Chert-Total feldspars

(d) Volcanic rock fragments-Metamorphic rock fragments-Sedimentary rock fragments 
calculated from porosity, such as permeability or fluid saturations). This is a concern for all Cook Inlet reservoirs, but becomes particularly acute at the lower porosities expected in tight gas sandstones.

Similarly, interpretation of clay content in these sandstones can be problematic: a relatively high content of alkali feldspars, muscovite and biotite, and in some cases heavy minerals or lignitic organics, all serve to give these sandstones a fairly high gamma ray response, minimizing the contrast with true shales. Furthermore, many of the clays of interest in these sandstones are authigenic (kaolinite, smectite) and very different from the clay assemblage in interbedded shales. Shaly sandstones exhibit extremely low permeabilities, and do not represent pay in most cases; they need to be recognized as such. Matrix-free sandstones with even moderate amounts of pore-filling kaolinite (non-radioactive) or smectite will have decreased permeability, increased microporosity and water saturation, and diminished relative permeability to gas compared to their counterparts without authigenic clays. Detecting and quantifying the presence of such authigenic clays is a challenge.

Small pores and pore throats in the deeper, stronglycompacted sandstones of this study are associated with high levels of irreducible water saturation, despite their coarse grain size. A $1 \mathrm{md}$ sandstone is estimated to have a water saturation of around 40 percent PV at $400 \mathrm{ft}$ above FWL (fig. 26). Much of the water-filled porosity is likely to be microporosity within the argillaceous rock fragments, partially leached feldspars, and aggregates of authigenic clay that occur in many of these samples. The median amount of microporosity in these sandstones is just over 8 percent by volume. Wireline log-derived porosities and water saturations are liable to be pessimistic, and will overestimate the actual $\mathrm{S}_{\mathrm{w}}$ within the effective pore network of the reservoir. Given the small expected size of pores and pore apertures in well-compacted sandstones here, even an accurate estimate of $S_{w}$ irr will be higher than normal for a more conventional reservoir.

Low porosities and tightly compacted sand frameworks may have the effect of minimizing or eliminating the effect of free gas on the seismic response of the reservoir. Exploration methods that rely exclusively on seismic evidence of gas saturation may miss some significant tight-gas reservoirs.

\section{CONCLUSIONS}

Tertiary sandstones from Cook Inlet Basin retain significant potential as tight gas reservoirs (with permeabilities on the scale of $1 \mathrm{md}$ ) to substantial burial depths. In sand-rich intervals, these sandstones can constitute sufficiently large targets (albeit quite heterogeneous) to provide commercial levels of production rate and perwell gas reserves (most likely aided by fracture stimula- tion and/or high-angle well bores). The sandstones fall into two main textural groups: very fine-grained, somewhat silty with minor to moderate clay matrix; and fine to medium-grained or coarser, in some cases pebbly and bimodal, otherwise well sorted and matrix-poor. Very fine-grained sandstones lose macroporosity and permeability very rapidly with burial; coarser-grained sandstones retain effective pores and permeability to much greater depths. Deep, tight gas reservoirs are apt to be developed primarily in the coarser facies. Sand composition is dominated by quartz, feldspars, volcanic and metasedimentary lithic fragments, and mica. Sand provenance is a mixture of crystalline basement and volcanic rocks derived from a dissected arc terrane, and marine sedimentary and low-grade metasedimentary fragments recycled from an accretionary wedge outboard of the basin. An arc, an accretionary wedge, and a craton alternate over time as the dominant source; the basin fill becomes increasingly homogeneous over time, with less lateral variability. Many of the sand grains (lithic fragments, mica) behave quite ductilely during burial compaction, whereas quartz and unaltered feldspars are rigid, subject to fracturing but not plastic deformation. As a result of the relatively rapid burial of such ductilerich sandstones, mechanical compaction is the dominant diagenetic process: intergranular volumes less than 15 percent are quite common. The average loss of intergranular volume with depth is about 3.6 percent units per 1,000 ft. Pore-filling authigenic cements (mostly calcite, kaolinite) are uncommon and generally minor, forming scattered irregular patches. There are indications that cementation may become more significant at depths below 10,000 ft or so (present depth). With progressive compaction, the sandstone pore system evolves from one dominated by large, well-connected intergranular macropores to one with mostly small mesopores $(<20$ microns), connected by apertures of 1 micron or less, associated with significant amounts of ineffective microporosity. Capillary pressure analyses of selected samples provide evidence of the pronounced constriction of dominant pore aperture sizes with increasing burial, elevated entry pressures, and a correlation between absolute permeability and (relatively high) irreducible water saturations. For low-permeability sandstones, the gas/water contact will not be sharply defined, but will consist of a broad transition zone.

Mechanical compaction with increasing burial is a major process driving changes in sandstone reservoir quality. The primary controls on mechanical compaction are effective stress (maximum burial depth, which may be significantly deeper than current depths on top of large tectonic structures) and sand texture. The amount and type of ductile grains probably play a secondary role as well, but no clear correlations are possible with the limited available samples. The evaluation of potential 
gas reservoirs in such sandstones is complicated by high levels of water-filled microporosity, a radiogenic sand grain framework, and presence of non-radiogenic clays (kaolinite), highly variable matrix density, and poorly constrained rock physics parameters.

\section{RECOMMENDATIONS FOR FURTHER STUDY}

The results of this preliminary petrographic study clearly demonstrate the viability of Tertiary sandstones of Cook Inlet as gas reservoirs even at low porosities and significant burial depths. The major problems facing tight gas exploration in Cook Inlet are related to reservoir charge (relative timing of hydrocarbon maturation-in the case of the Jurassic-source-charged thermal system, development of trapping structures, and evolution of reservoir quality) and seal (structures sufficiently large to be of interest will require high-quality seals). As a follow-up to this report on reservoir properties, several further studies could address the remaining serious technical issues and provide practical exploration tools.

Regional log-based petrophysical study of compaction trends in both sandstones and shales, concentrating on porosity-depth and velocity-depth relationships. Such a study would be critical to forward seismic modeling of the response of low-porosity, gas-charged sands, to refine our understanding of sandstone porosity evolution, to highlight the locations of anomalous rock properties (due to erosional uplift or overpressuring), and as a first step towards a model of changing seal integrity as a function of stratigraphic age, burial depth, and physical properties. A possible side benefit would be a rough calibration of what constitutes gas pay, in terms of porosity and water saturation; this is liable to be a difficult evaluation problem, as discussed above, particularly in the more lithic-rich sandstones. Such information would also be critical for planning of hydraulic fracture stimulations, a standard practice for tight reservoirs onshore.

Burial history modeling of selected areas in the ba$\sin$, to address the question of the timing of gas charge relative to that of the trap development, and the reservoir properties to be expected at the time of charging. This information would be of particular interest when focused on stratigraphic units with the potential to be self-sourcing (e.g., intercalated sands and coals), and in situations where oil or bitumen could be present as well as gas.

Further useful petrographic work would include: study of a suite of more deeply-buried samples $(>10,000$ $\mathrm{ft}$ or so), to investigate the hints of increased authigenic cement development noted in the current study, and to document better the expected variability of reservoir properties at advanced stages of burial compaction; lab studies of sandstone elastic properties (in conjunction with the log-based efforts mentioned above) to improve seismic modeling and interpretation of deeply buried gas reservoirs, and planning of hydraulic fracture stimulations; and geochemical studies (primarily stable isotope and fluid inclusion) of authigenic phases to calibrate the timing of cement development and improve burial history models.

Typically, conventional tight gas reservoirs are deep, to afford the pressures necessary to drive acceptable delivery rates and volumes. The wells to develop such reservoirs are liable to be mechanically challenging and expensive, so a premium will be placed on accumulations that can be developed with a small number of high-reserve wells. Exploration for such accumulations will require a high degree of confidence in the geologic model (volume and connectivity of favorable sand facies, gas charge and trap development, seal integrity, estimated reservoir quality) and in the interpretation of seismic response (structural closure, fluid and porosity effects on seismic attributes and AVO response). Given the heterogeneous non-marine depositional facies dominant throughout much of the Tertiary in the Cook Inlet, there are risks associated even with large structures that have direct seismic evidence of gas saturation. An effective exploration strategy for low-permeability reservoirs will include local basin analysis and depositional facies modeling, and should not rely solely on the presence of any direct seismic indication of gas. This study has concentrated on conventional gas reservoirs; unconventional reservoirs, such as coalbed methane and gas shales, may well be viable targets onshore, and present a number of their own specific technical issues.

\section{REFERENCES}

Calderwood, K.W., and Fackler, W.C., 1972, Proposed Stratigraphic Nomenclature for the Kenai Group, Cook Inlet Basin, Alaska: AAPG Bulletin, v. 56, no. 4, p. 739-754.

Dickinson, W.R., Beard, L.S., Brakenridge, G.R., Erjavec, J.L., Ferguson, R.C., Inman, K.F., Knepp, R.A., Lindberg, F.A., and Ryberg, P.T., 1983, Provenance of North American Phanerozoic sandstones in relation to tectonic setting: Geological Society of America Bulletin, v. 94, no. 2, p. 222-235.

Haeussler, P.J., Bruhn, R.L., and Pratt, T.L., 2000, Potential seismic hazards and tectonics of the upper Cook Inlet basin, Alaska, based on analysis of Pliocene and younger deformation: Geological Society of America Bulletin, v. 112, no. 9, p. 14141429.

Hartman, D.C., Pessel, G.H., and McGee, D.L., 1972, Preliminary report on stratigraphy of the Kenai group, upper Cook Inlet, Alaska: Alaska Division of Geological Survey Special Report 5, 4 p., 11 sheets, scale $1: 500,000$. 
Magoon, L.B., 1994, Tuxedni-Hemlock(!) petroleum system in Cook Inlet, Alaska, USA, in Magoon, L.B., and Dow, W.G., eds., The petroleum system; from source to trap: AAPG Memoir 60, p. 359-370.

Magoon, L.B., and Claypool, G.E., 1981, Petroleum geology of the Cook Inlet Basin; An exploration model: AAPG Bulletin, v. 65, no. 6, p. 1043-1061.

Ryherd, T., 2003, Cook Inlet Oil \& Gas, presentation for Alaska Department. of Natural Resources, available (pdf format) at http://www.dog.dnr.state.ak.us/ oil

Swenson, R.F., 1997, Introduction to Tertiary tectonics and sedimentation in the Cook Inlet Basin, in Karl, S.M., Ryherd, T., and Vaughn, N., eds., Guide to the Geology of the Kenai Peninsula, Alaska: Alaska Geological Society, Field Guide Series, p. 18-27. 
Appendix

\section{List of photomicrographs, by well and depth}

\section{Field of}

\begin{tabular}{lrlll} 
Well & Depth & \multicolumn{1}{c}{ File } & view $(\mathbf{m m})^{\mathbf{a}}$ & \multicolumn{1}{c}{ Notes } \\
BCU 9 & $7,992.5$ & BCU9_7,992a & 5 & Small Chondrites(?) burrows \\
BCU 9 & & BCU9_992b & 2.5 & Organic material, bioturbated fabric \\
BCU 9 & & BCU9_7992c & 0.65 & Silty shale matrix \\
BCU 9 & $8,085.5$ & BCU9_8085a & 5 & Large lignite flakes \\
BCU 9 & & BCU9_8085ab & 2.5 & Organic material in shale \\
BCU 9 & & BCU9_8085c & 0.65 & Microporosity in silty shale
\end{tabular}

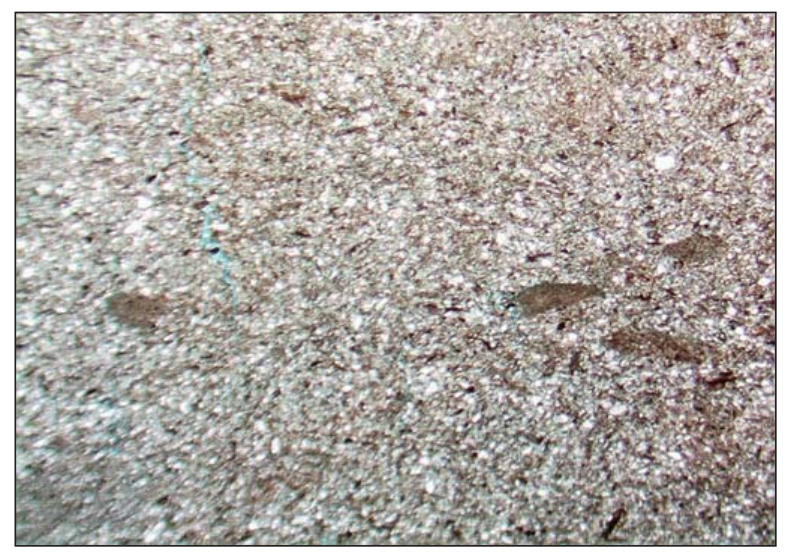

BCU9_7992a
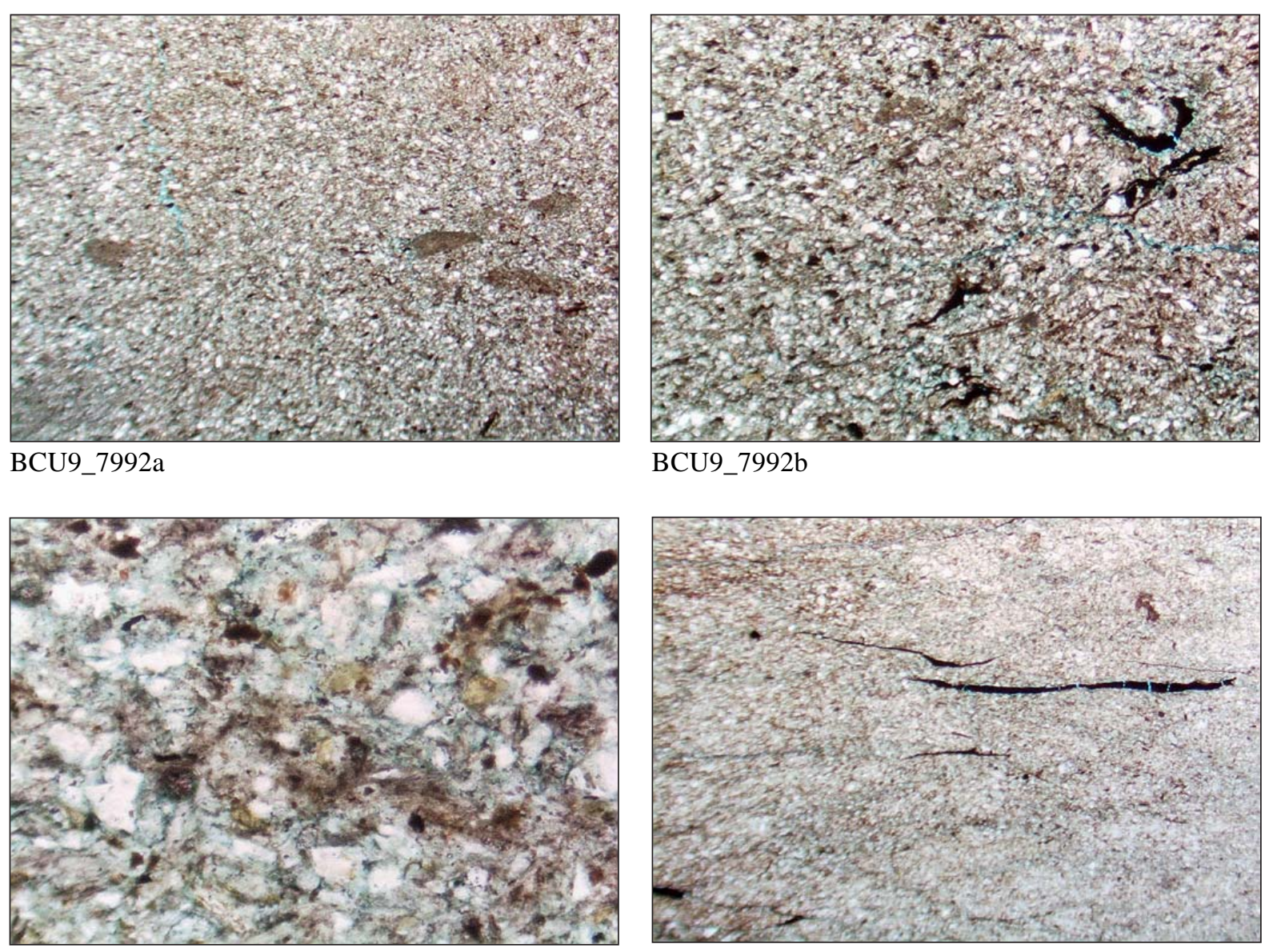

BCU9_7992c

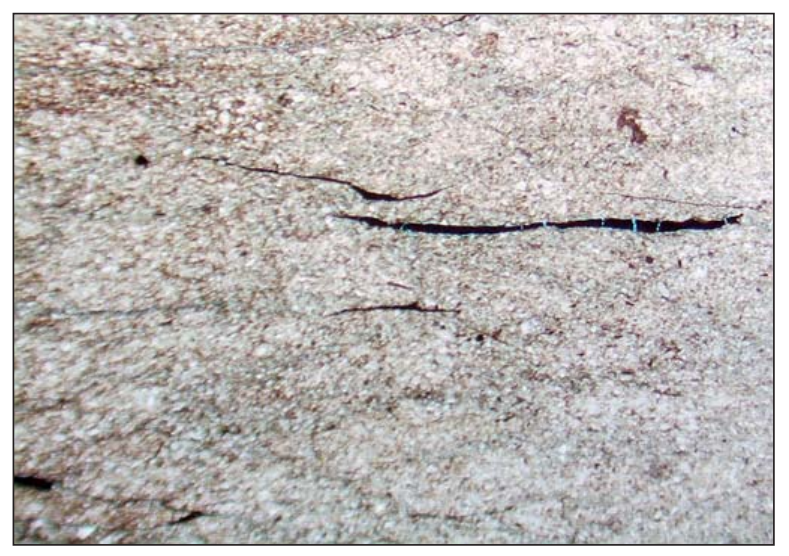

BCU9_8085a

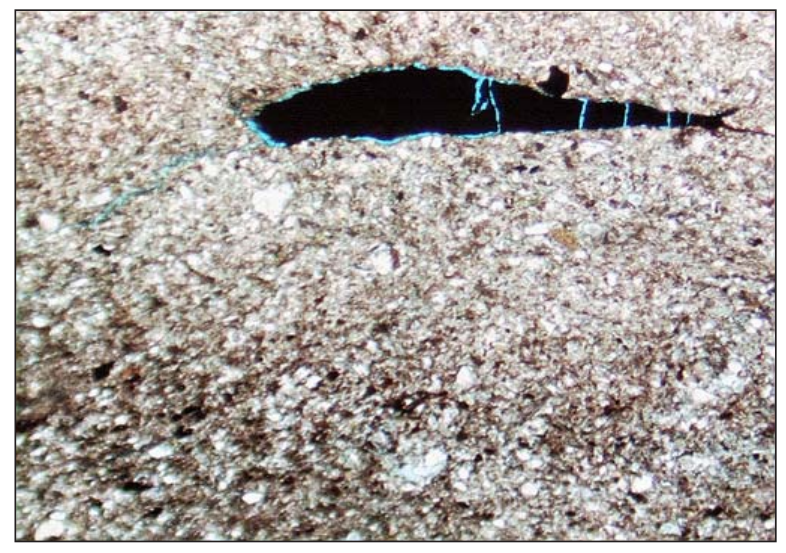

BCU9_8085ab

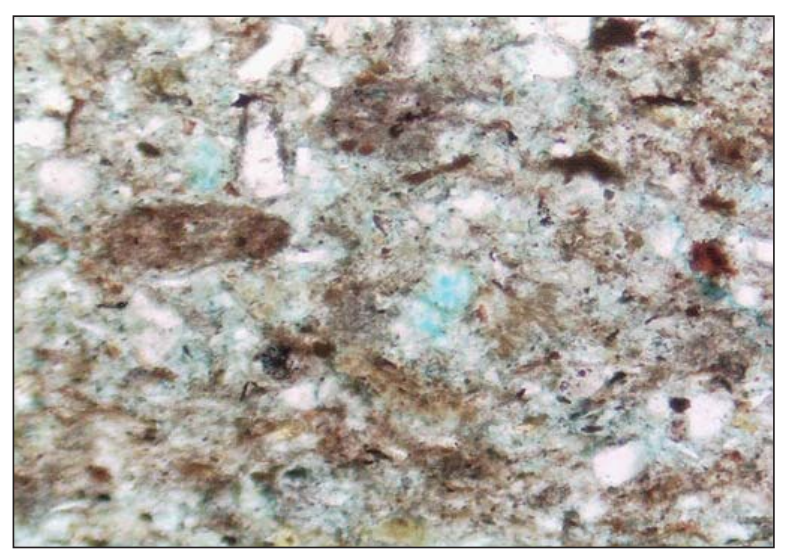

BCU9_8085c

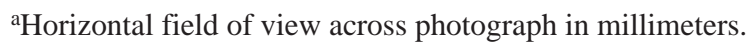


Appendix 1. List of photomicrographs, by well and depth-continued

\begin{tabular}{|c|c|c|c|c|}
\hline Well & Depth & File & $\begin{array}{c}\text { Field of } \\
\text { view }(\mathbf{m m})^{\mathrm{a}}\end{array}$ & Notes \\
\hline Beluga River 1 & 11590 & Beluga11590a & 5 & Faint planar laminae in tight shaly sandstone \\
\hline Beluga River 1 & & Beluga11590b & 2.5 & Micritic biotite in tight sandstone \\
\hline Beluga River 1 & & Beluga11590c & 0.65 & Micritic biotite, compaction \\
\hline PCRRYVLLA15 & 11,142 & CRVLA11142a & 5 & Close-packed; micritic biotite \\
\hline PCRRYVLLA15 & & CRVLA11142b & 2.5 & Metasedimentary lithic, plutonic rock fragment, kaolinite \\
\hline PCRRYVLLA15 & & CRVLA11142C & 0.65 & Pore-filling kaolinite \\
\hline
\end{tabular}

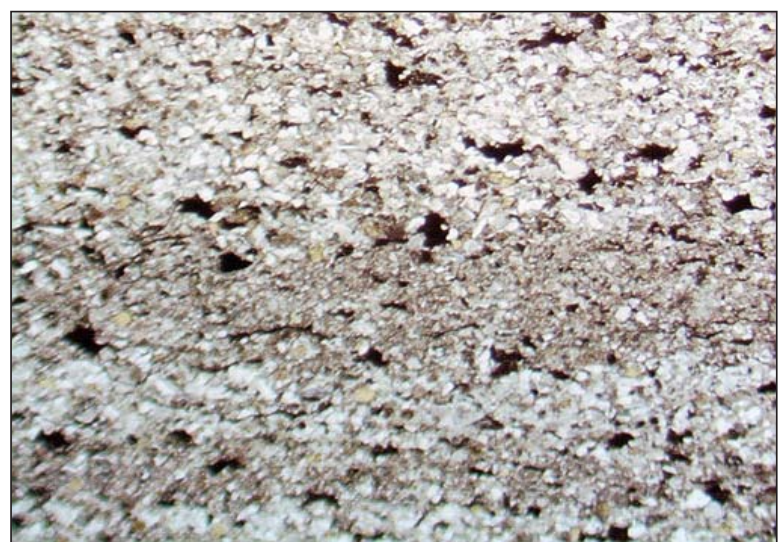

Beluga11590a

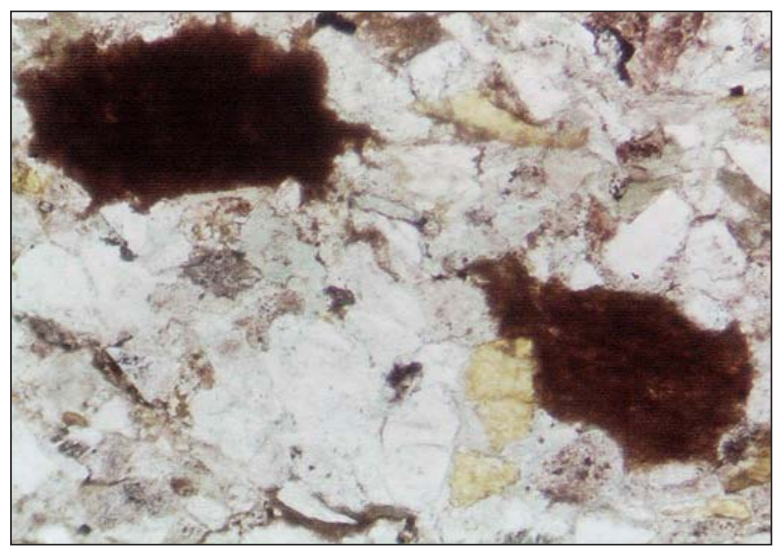

Beluga11590c

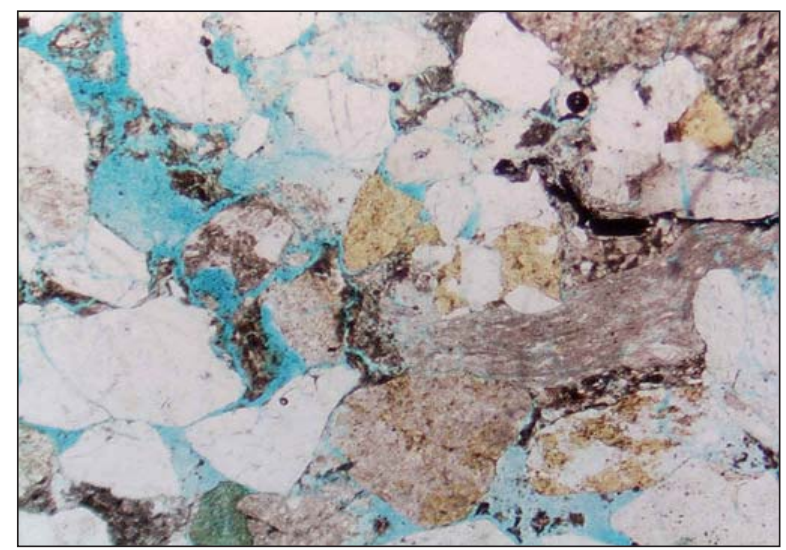

CRVLA11142b

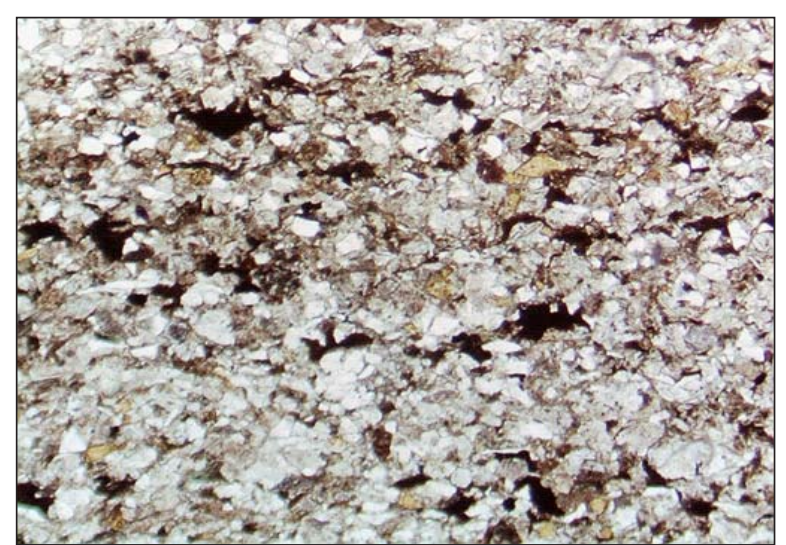

Beluga11590b

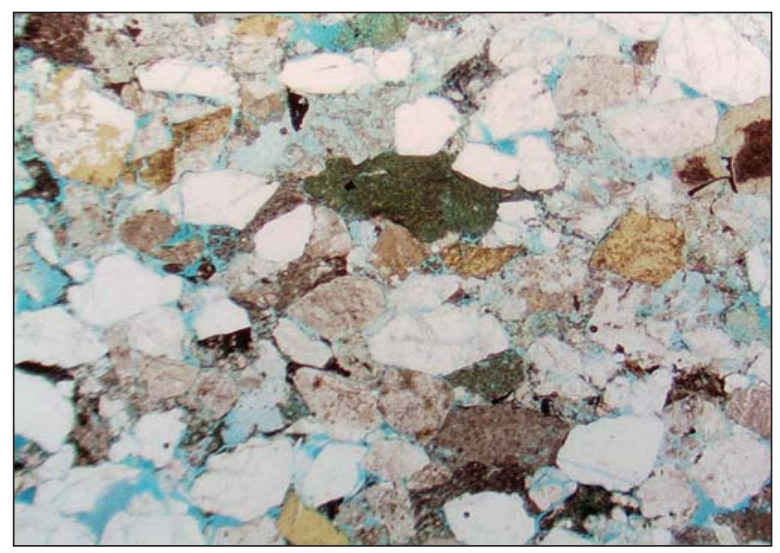

CRVLA11142a

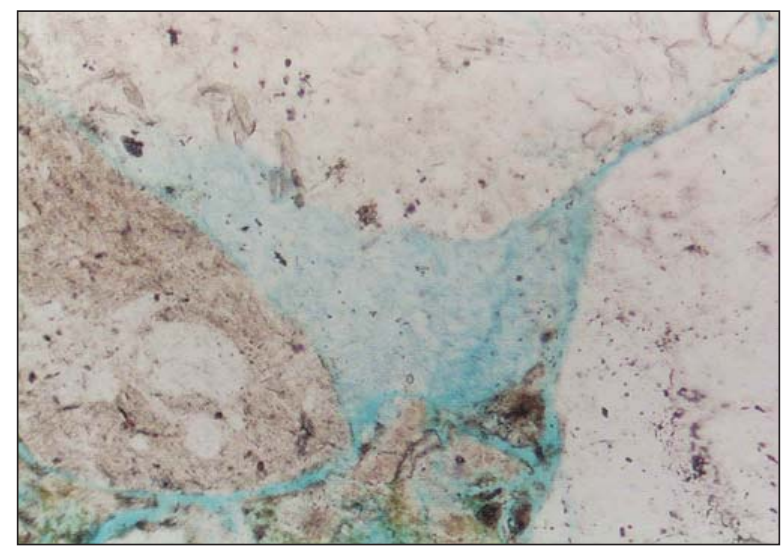

CRVLA11142C

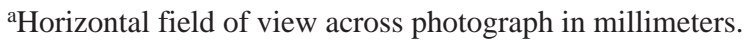


Appendix 1. List of photomicrographs, by well and depth-continued

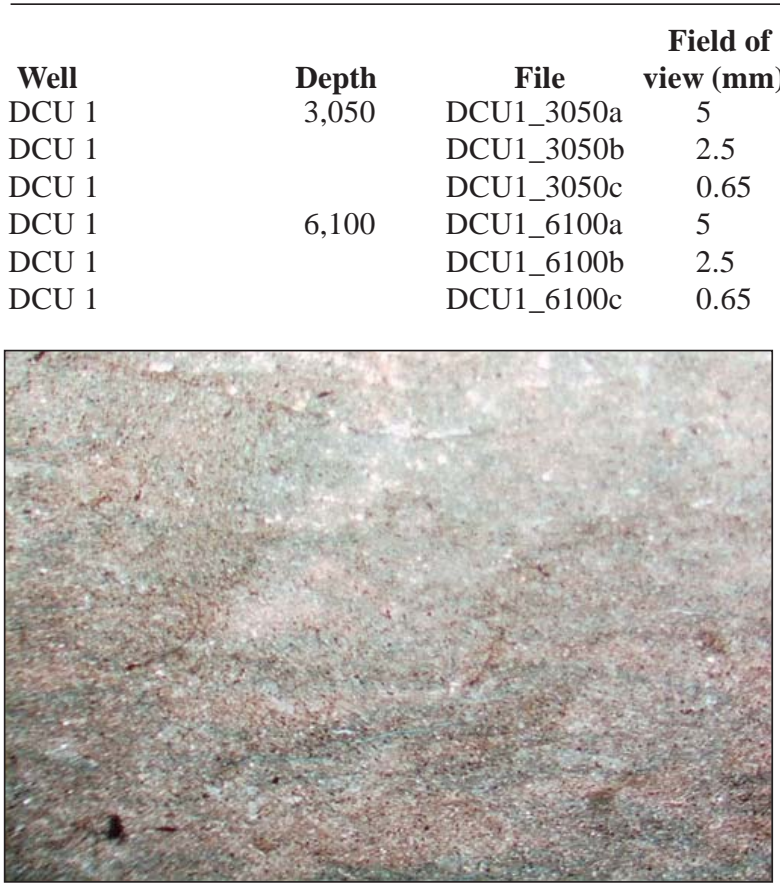

DCU1_3050a

Massive shale
Organic material in shale
Siderite microcrystals in matrix
Lignitic organic material, rip-ups
Biotite in moderately close-packed sandstone
Moderately squashed biotite, metasedimentary lithic

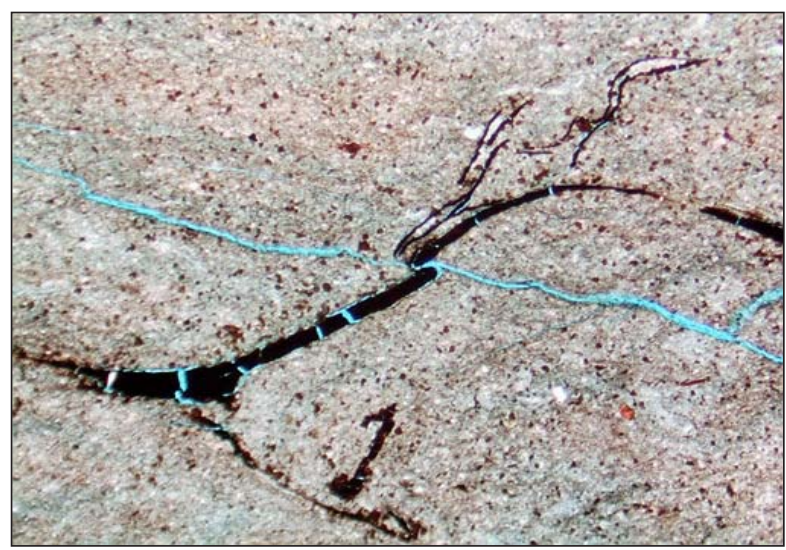

DCU1_3050b
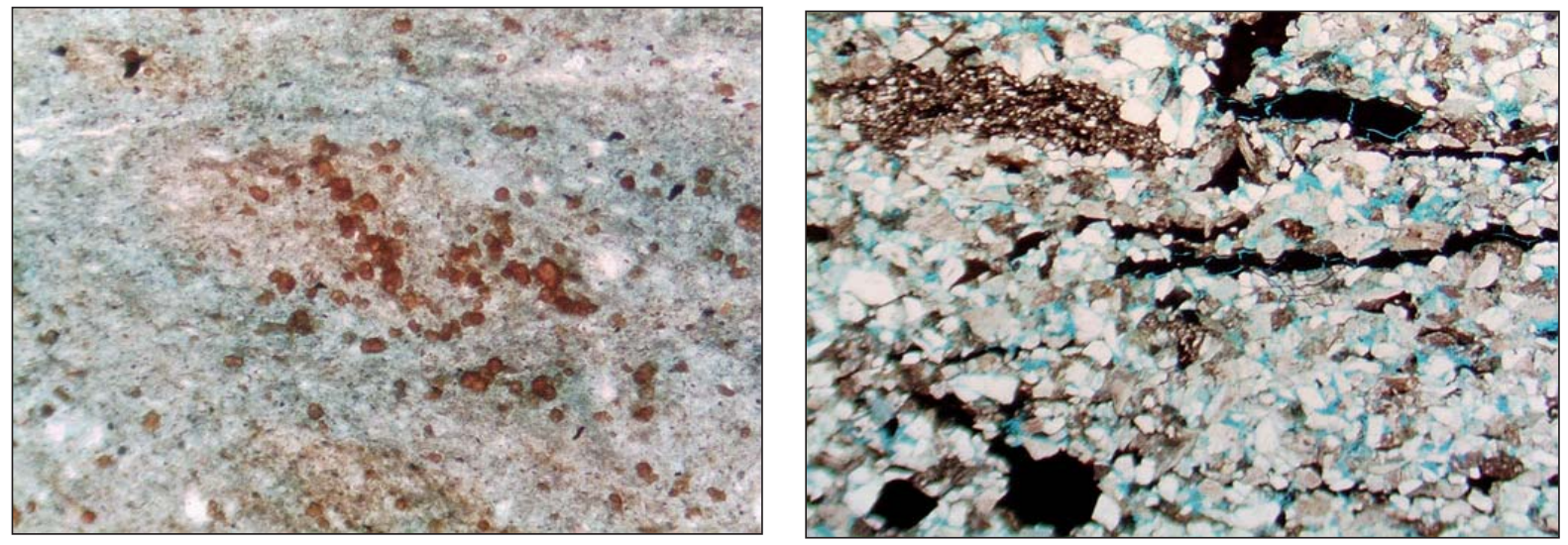

DCU1_3050c

DCU1_6100a

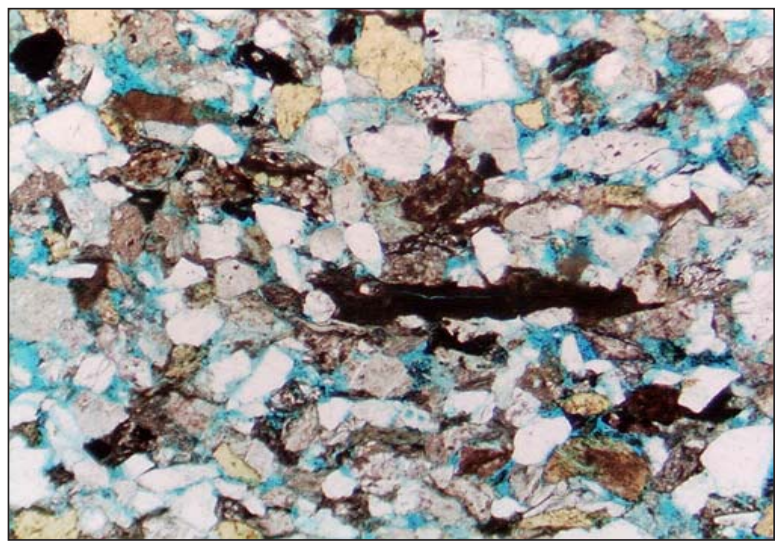

DCU1_6100b

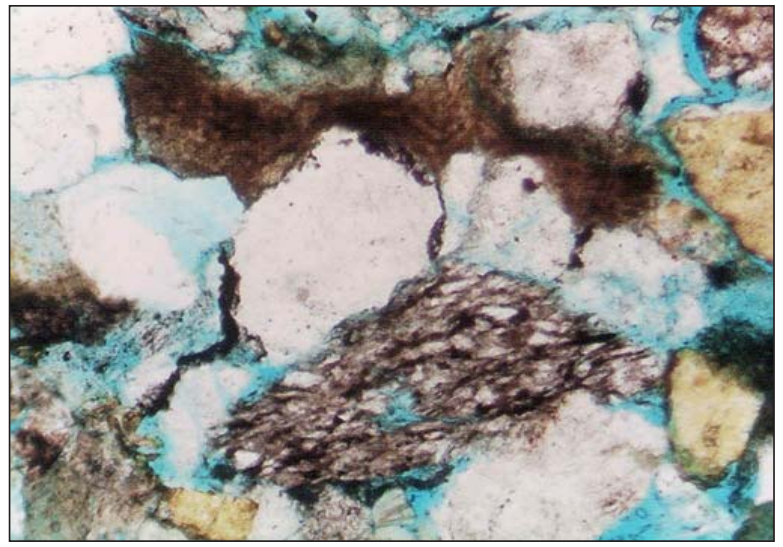

DCU1_6100c

${ }^{\text {a} H o r i z o n t a l ~ f i e l d ~ o f ~ v i e w ~ a c r o s s ~ p h o t o g r a p h ~ i n ~ m i l l i m e t e r s . ~}$ 
Appendix 1. List of photomicrographs, by well and depth-continued

\begin{tabular}{|c|c|c|c|c|}
\hline Well & Depth & File & $\begin{array}{c}\text { Field of } \\
\text { view }(\mathbf{m m})^{\mathrm{a}}\end{array}$ & Notes \\
\hline DCU 1 & 10,244 & DCU1_10244a & 5 & Large micritic biotite in close-packed sandstone \\
\hline DCU 1 & & DCU1_10244b & 2.5 & Squashed expanded micritic biotite \\
\hline DCU 1 & & DCU1_10244c & 0.65 & Pore-filling kaolinite with monocrystalline quartz, chert grains \\
\hline Dolly Varden ${ }^{\mathrm{b}}$ & 11722.1 & Dolly11722a & 5 & $\begin{array}{l}\text { Lithic fragment, sedimentary-sandstone in calcareous sandy } \\
\text { and pebble conglomerate }\end{array}$ \\
\hline Dolly Varden ${ }^{\mathrm{b}}$ & & Dolly11722b & 2.5 & Calcareous sandstone matrix \\
\hline Dolly Varden ${ }^{\mathrm{b}}$ & & Dolly11722c & 0.65 & Calcite/kaolinite pore-filling in matrix \\
\hline
\end{tabular}

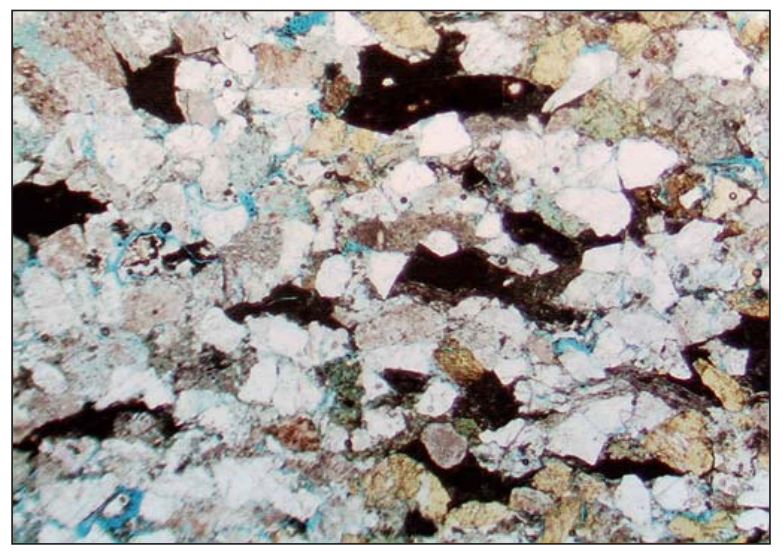

DCU1_10244a

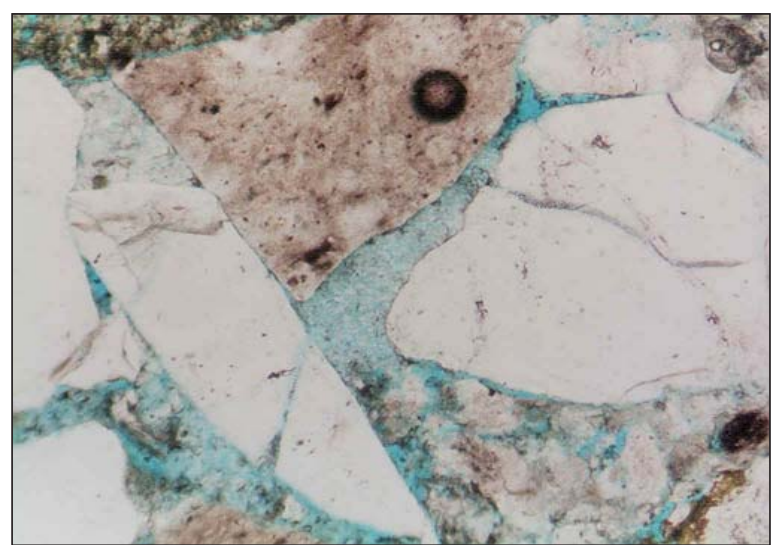

DCU1_10244c

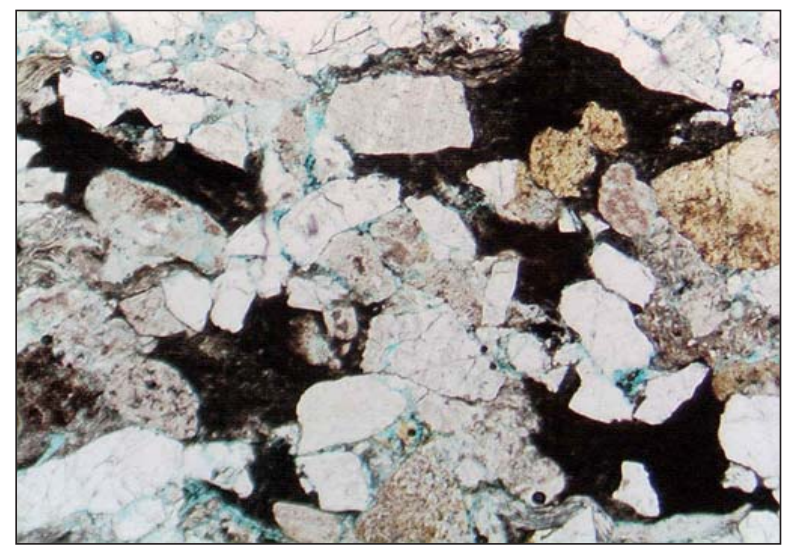

DCU1_10244b

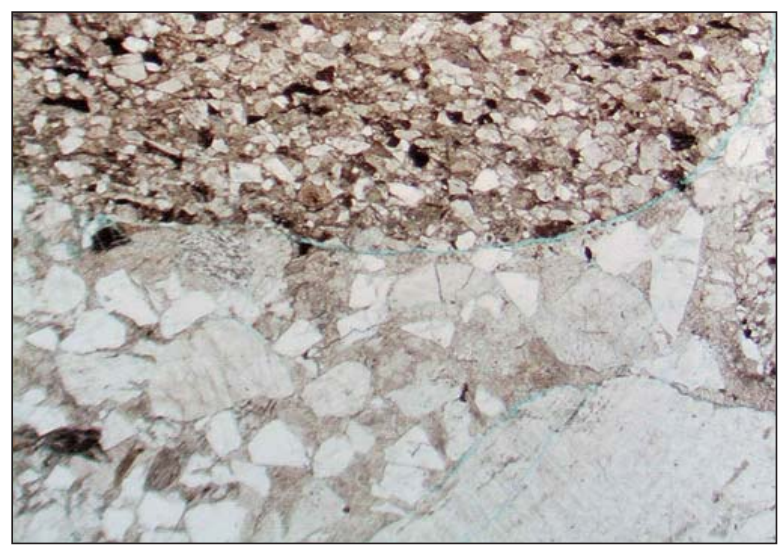

Dolly11722a

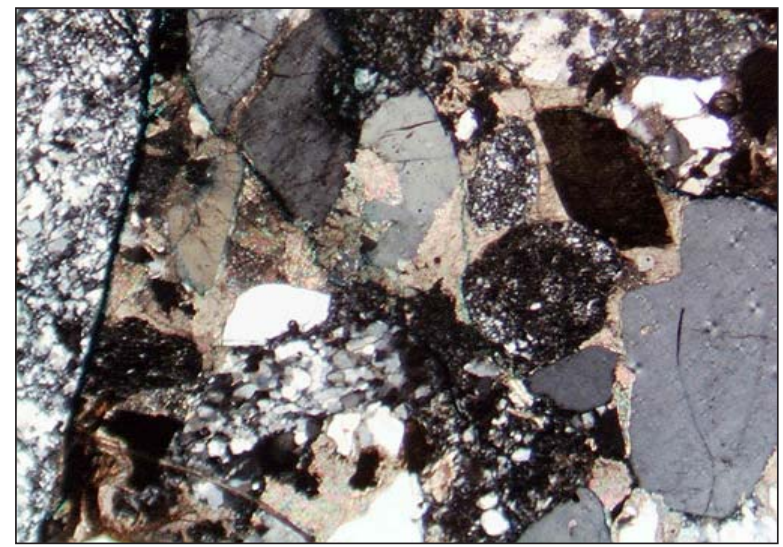

Dolly11722b

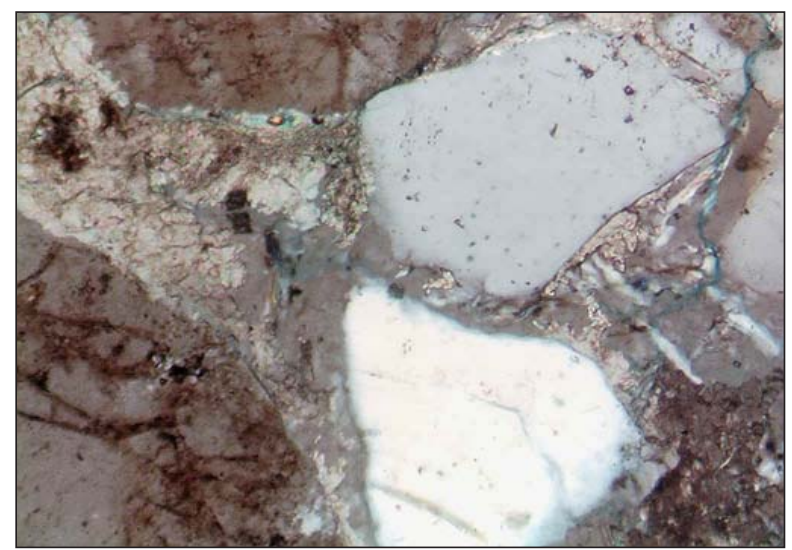

Dolly11722c

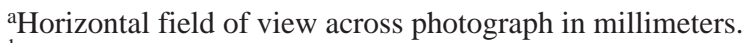
bW. McArthur. 
Appendix 1. List of photomicrographs, by well and depth-continued

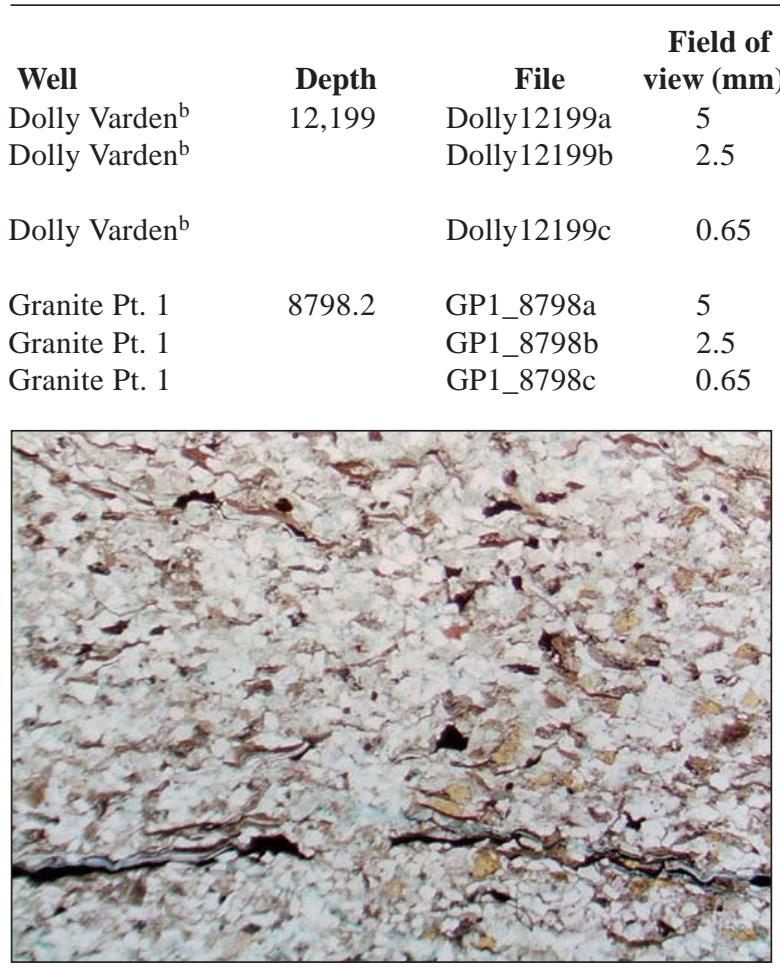

Dolly12199a

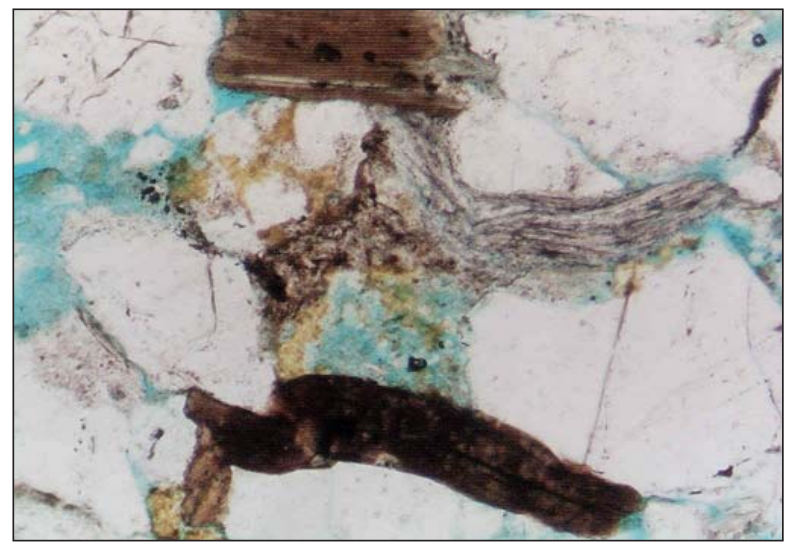

Dolly12199c

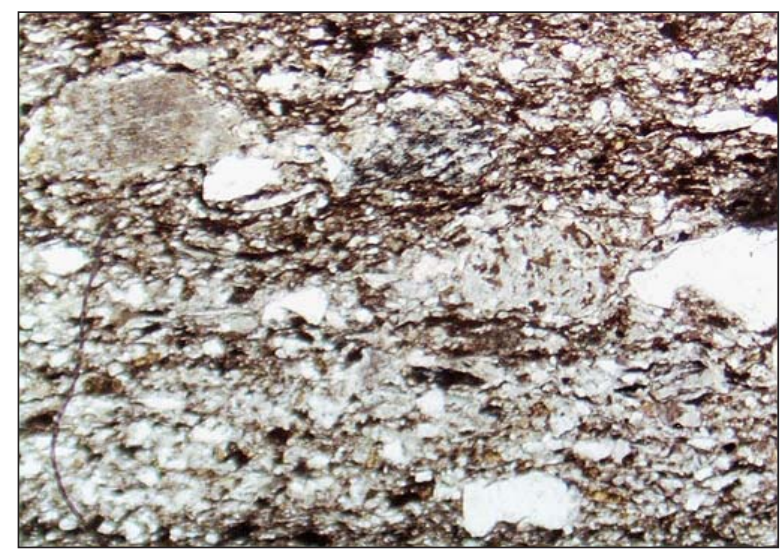

GP1_8798b

\section{Notes}

Slightly lignitic, micaceous, compacted sandstone

Coarser bed with heavy minerals, metasedimentary lithic, pores

Biotite, metasedimentary lithic, microporous lithic volcanic

Burrow, laminated shaly sand

Outsize sand grains

Compacted sandy bed

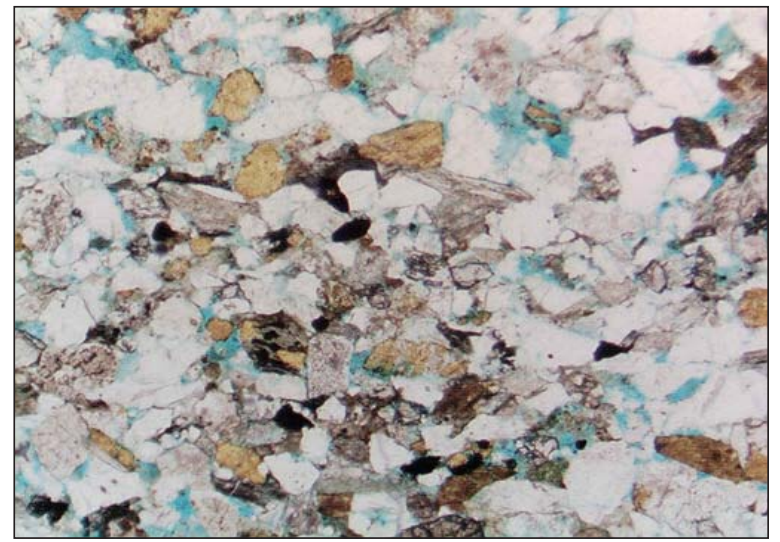

Dolly12199b

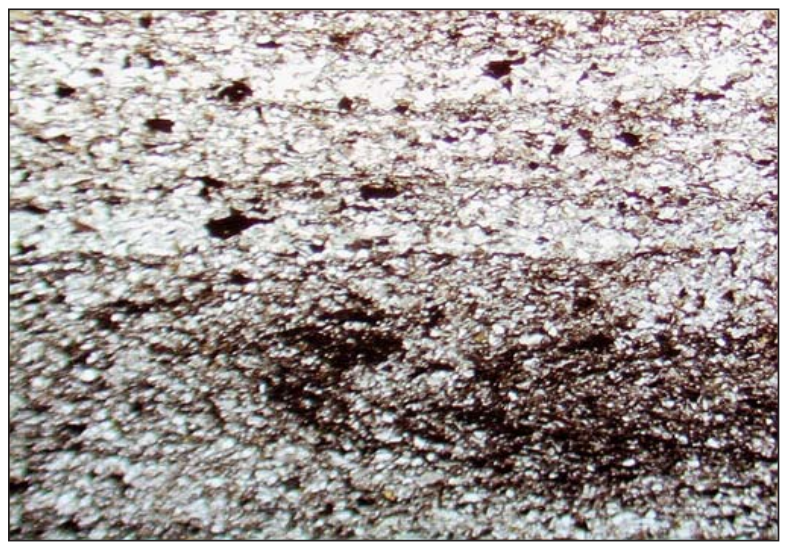

GP1_8798a

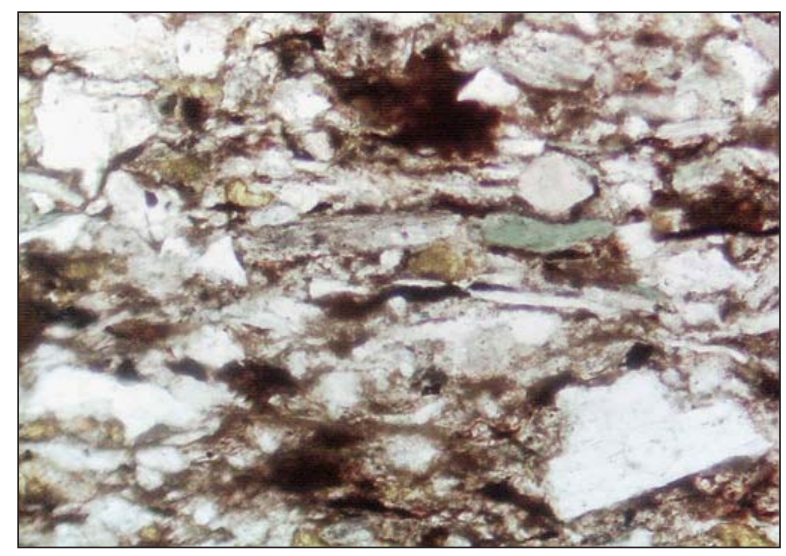

GP1_8798c

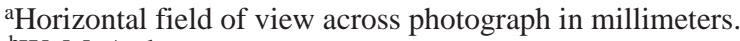

${ }^{b}$ W. McArthur. 
Appendix 1. List of photomicrographs, by well and depth-continued

\begin{tabular}{ccccl}
\hline & & \multicolumn{3}{c}{ Field of } \\
Well & Depth & $\begin{array}{c}\text { File } \\
\text { view (mm) }\end{array}$ & \multicolumn{1}{c}{ Notes } \\
Granite Pt. 1 & 9,253 & GP1_9253a & 5 & Tight, compacted, micaceous \\
Granite Pt. 1 & & GP1_9253b & 2.5 & Micritized biotite \\
Granite Pt. 1 & & GP1_9253c & 0.65 & Micritized biotite, pressure solution \\
Granite Pt. 1 & 9,467 & GP1_9467a & 5 & Coarse/fine bedding contact \\
Granite Pt. 1 & & GP1_9467b & 2.5 & Chert clast in coarse bed \\
Granite Pt. 1 & & GP1_9467c & 0.65 & Squashed mica, calcareous cement
\end{tabular}

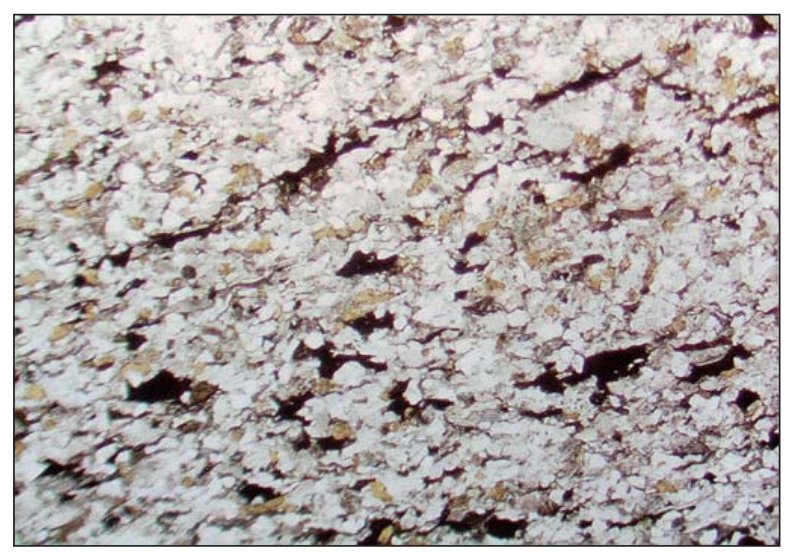

GP1_9253a

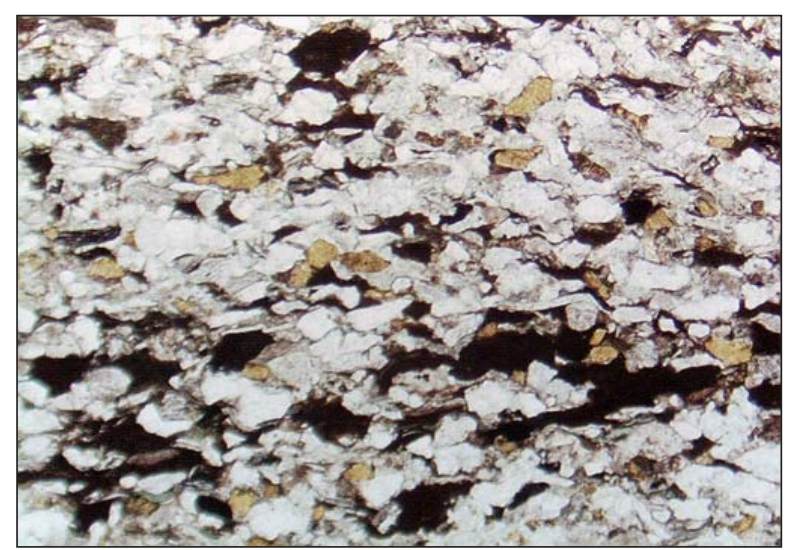

\section{GP1_9253b}

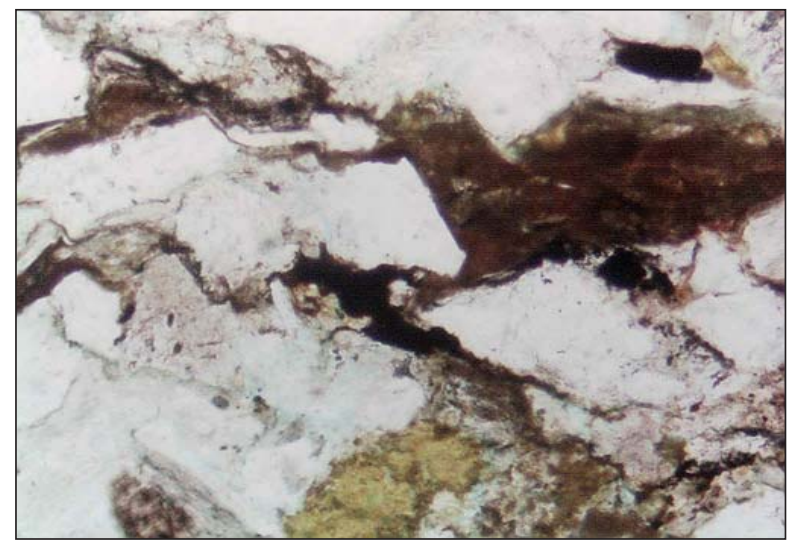

GP1_9253c
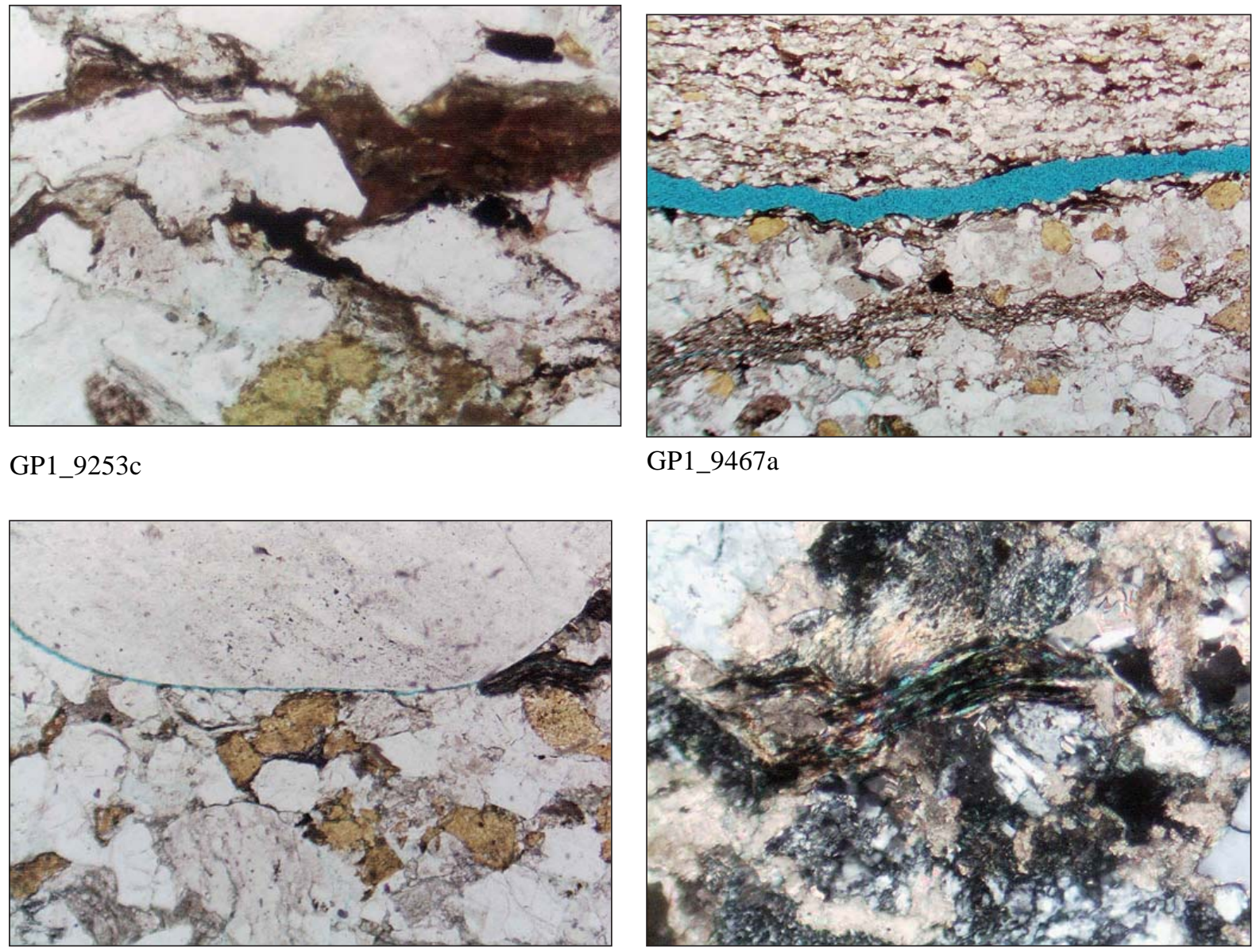

GP1_9467b

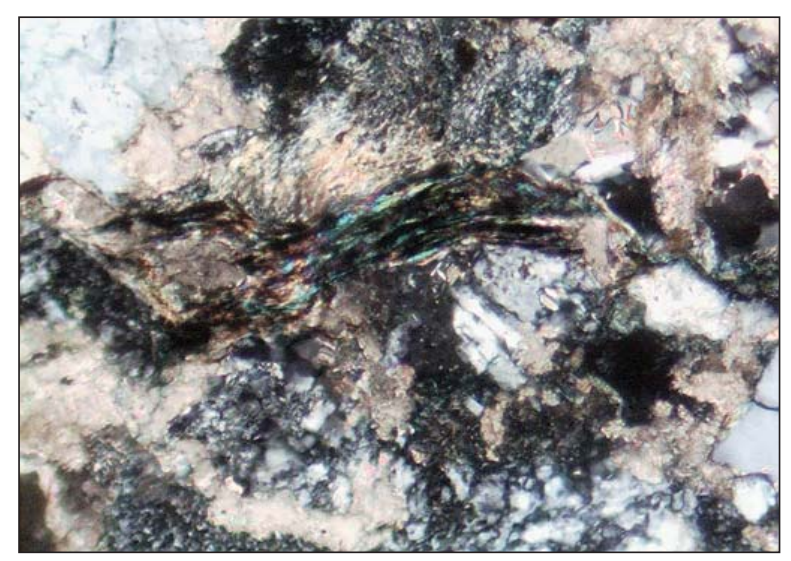

GP1_9467c

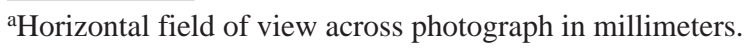


Appendix 1. List of photomicrographs, by well and depth-continued

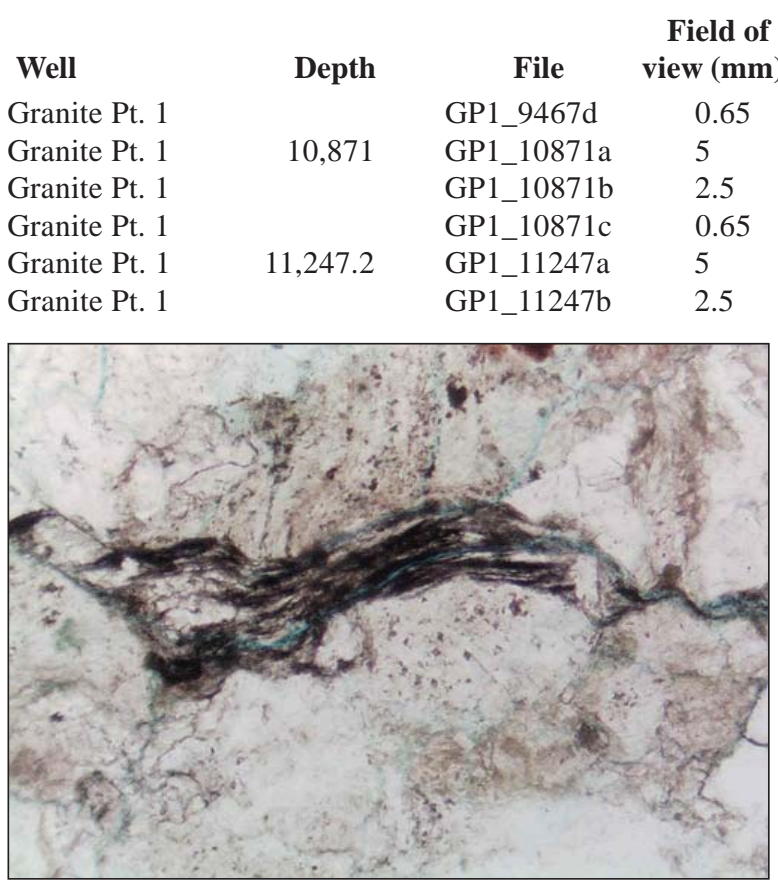

GP1_9467d

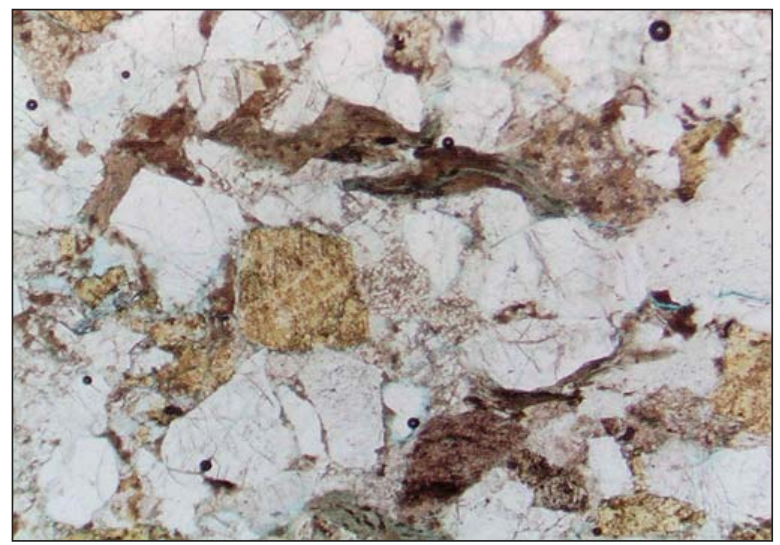

GP1_10871b

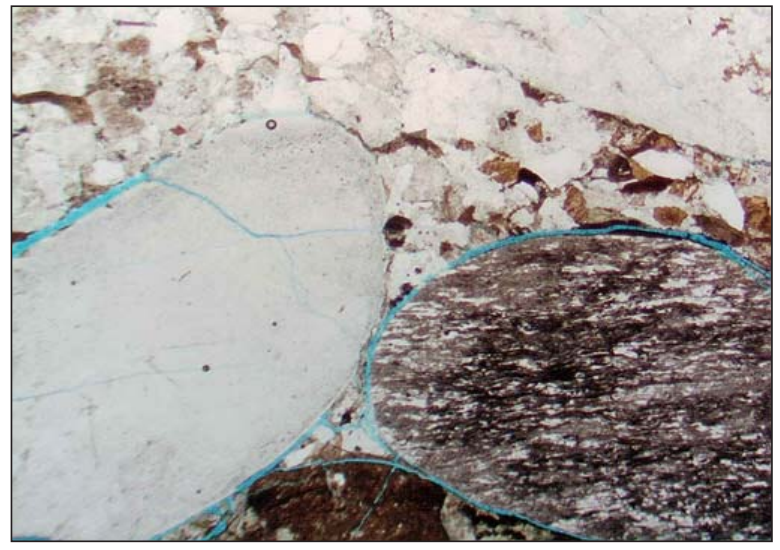

GP1_11247a

\section{Notes}

Crossed nicols view of above

Coarse micaceous arkose

Biotite in tight sandstone

Detrital chlorite, compaction, calcareous cement

Pebble conglomerate

Micaceous sandstone, volcanic pebble bed

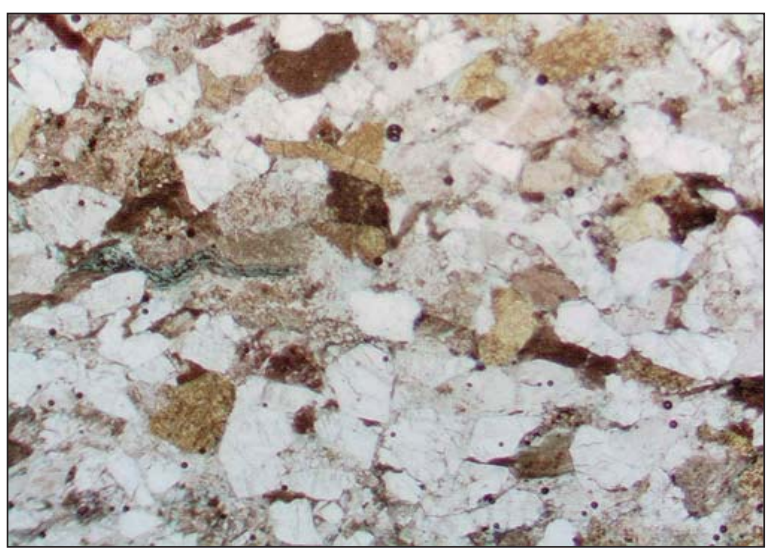

GP1_10871a

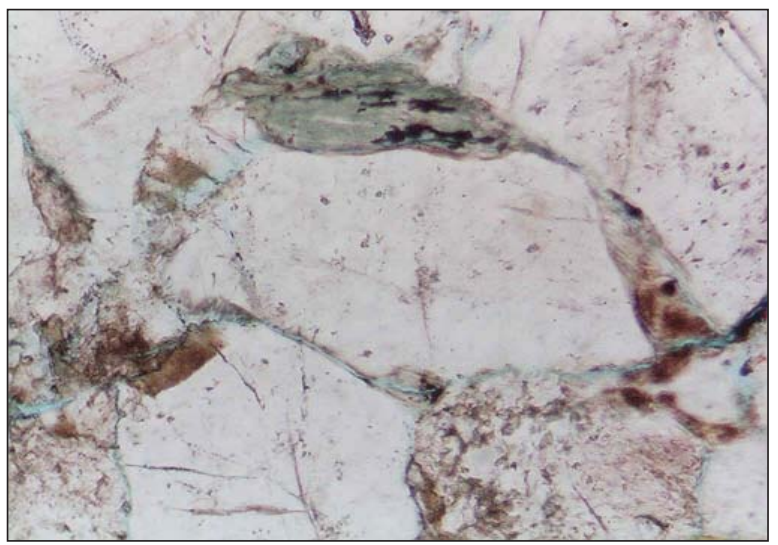

GP1_10871c

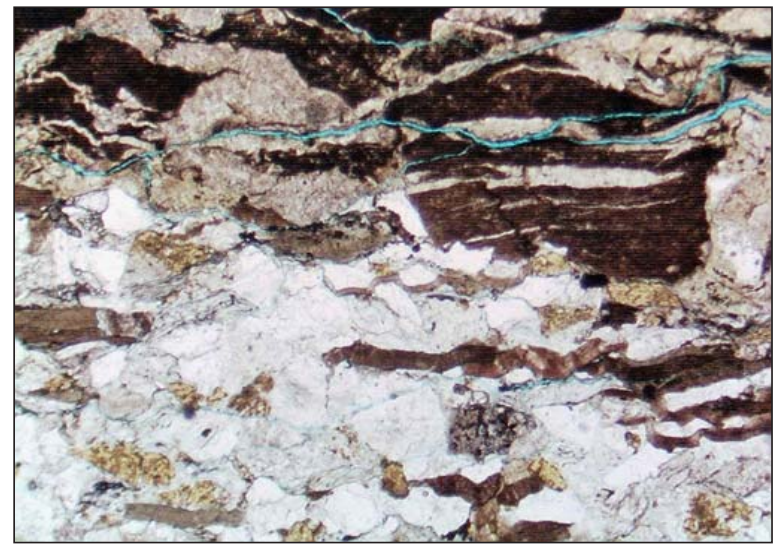

GP1_11247b

${ }^{a}$ Horizontal field of view across photograph in millimeters. 
Appendix 1. List of photomicrographs, by well and depth-continued

\section{Well \\ Depth}

Granite Pt. 1

Ivan River 44-1

Ivan River 44-1

Ivan River 44-1

Halasko King 1B

Halasko King 1B

$10,815.5$

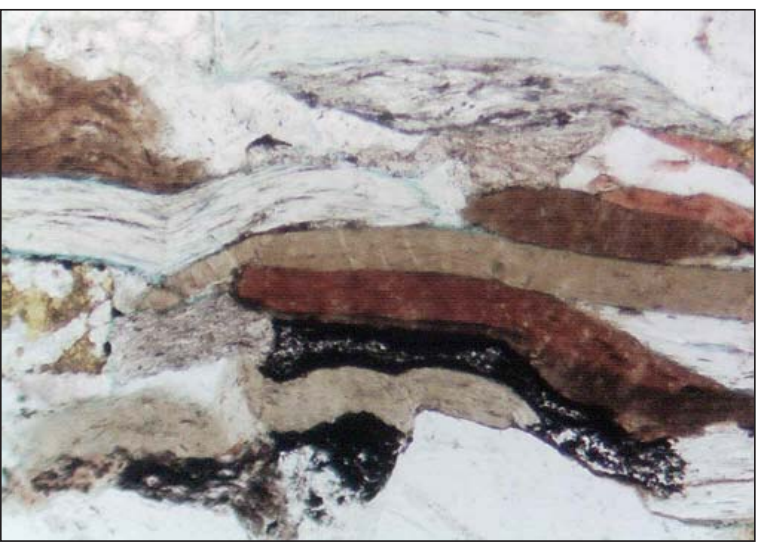

GP1_11247c

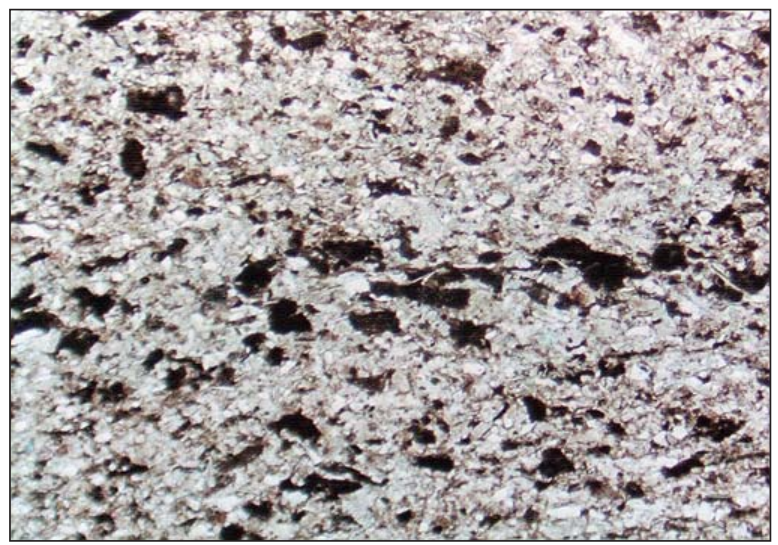

Ivan10815b

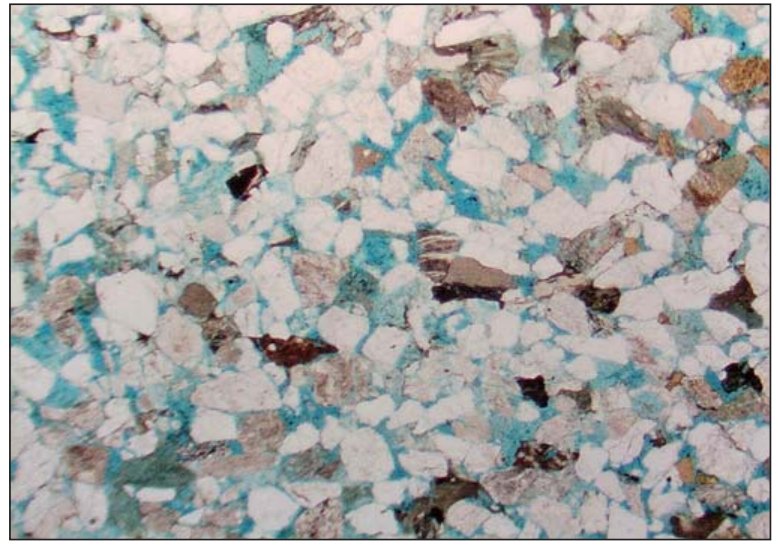

King13368a

\section{Field of}

GP1_11247c view (mm) $\quad 0.65 \quad$ Biotite-rich laminations in tight sandstone

Ivan10815a $\quad 5 \quad$ Silty micritic shale

Ivan10815b $\quad 2.5 \quad$ Micritized biotite

Ivan10815c $\quad 0.65 \quad$ Lignite flake, microcrystalline siderite

King13368a 5

King13368b $\quad 2.5$
Biotite, potassium feldspar, garnet, microporosity

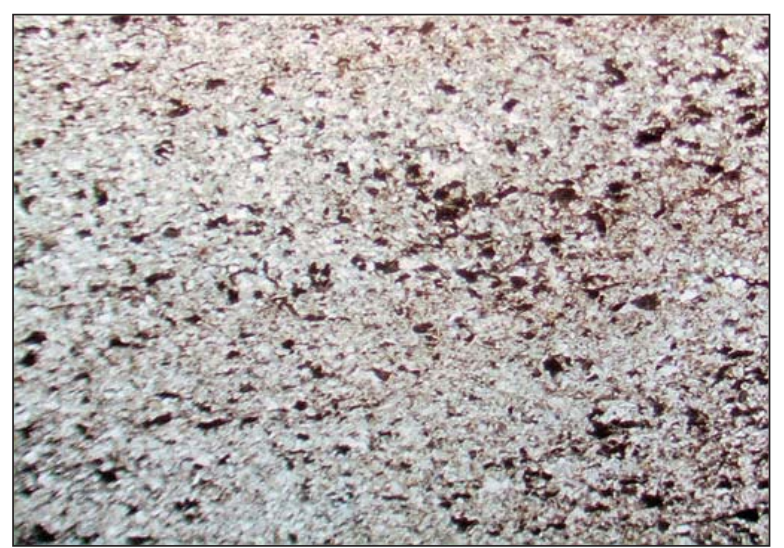

Ivan10815a

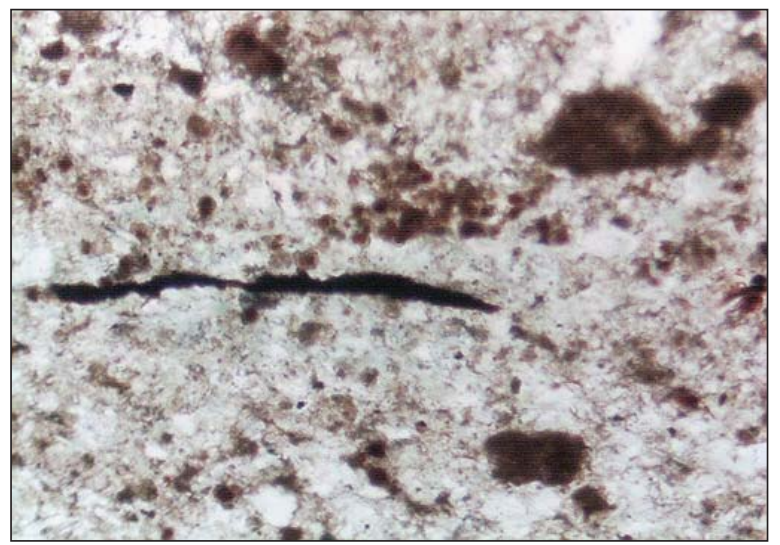

Ivan10815c

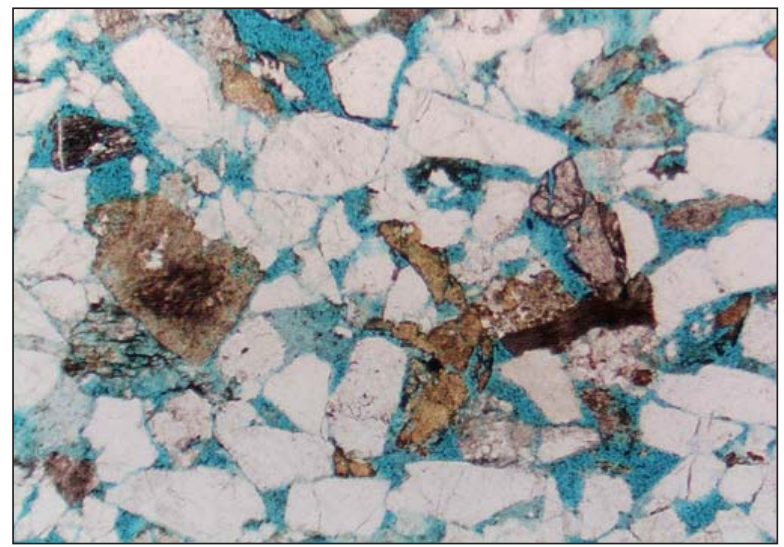

King13368b

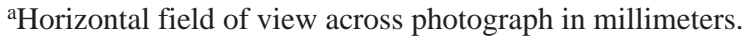


Appendix 1. List of photomicrographs, by well and depth-continued

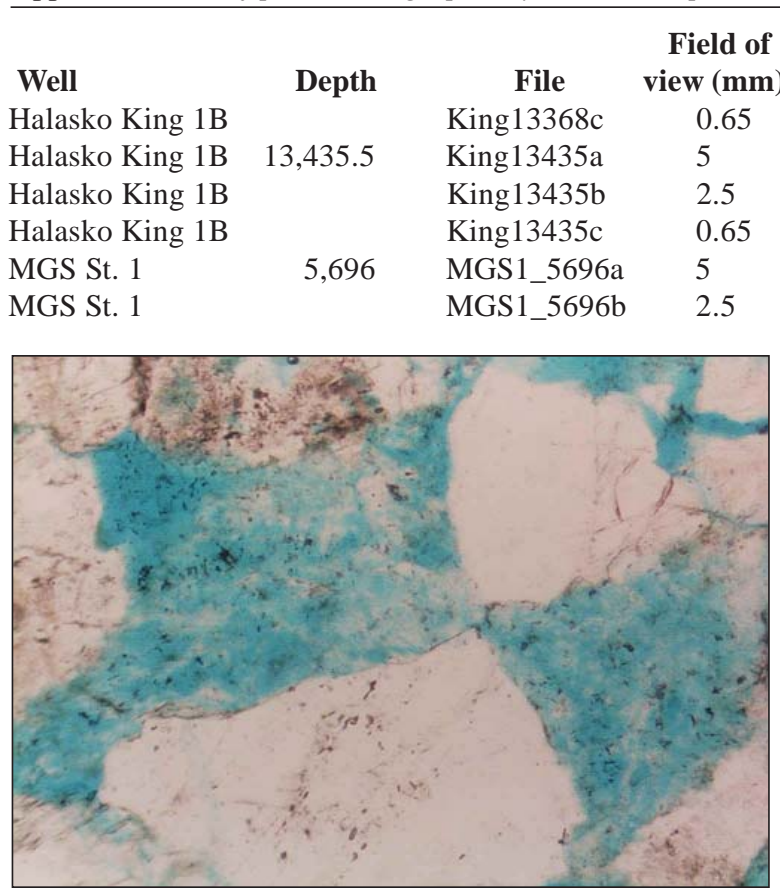

King13368c

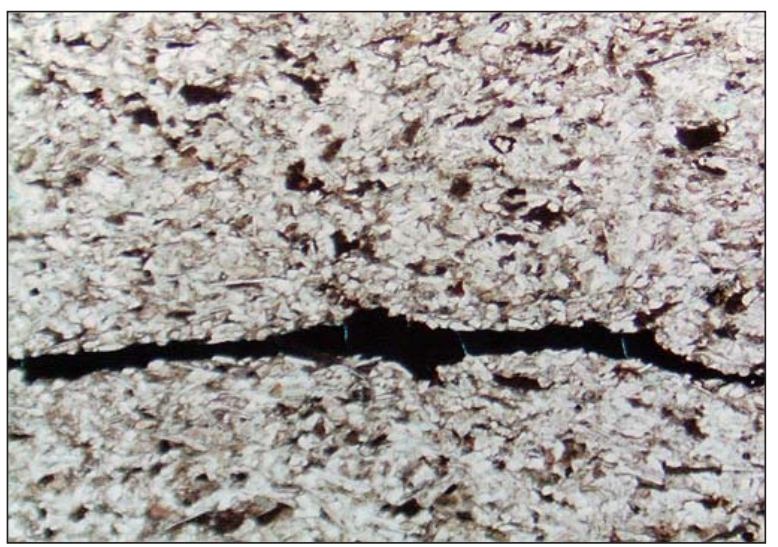

King13435b

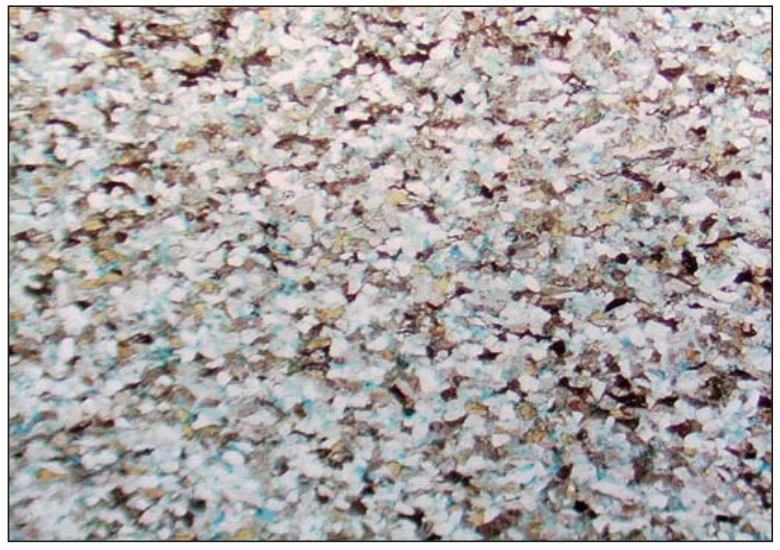

MGS1_5696a
Notes

Micaceous slightly lignitic laminae

Lignitic flake in tight sandstone

Micritic biotite in fine tight sandstone

Moderately close-packed arkose

Mica-rich lamination

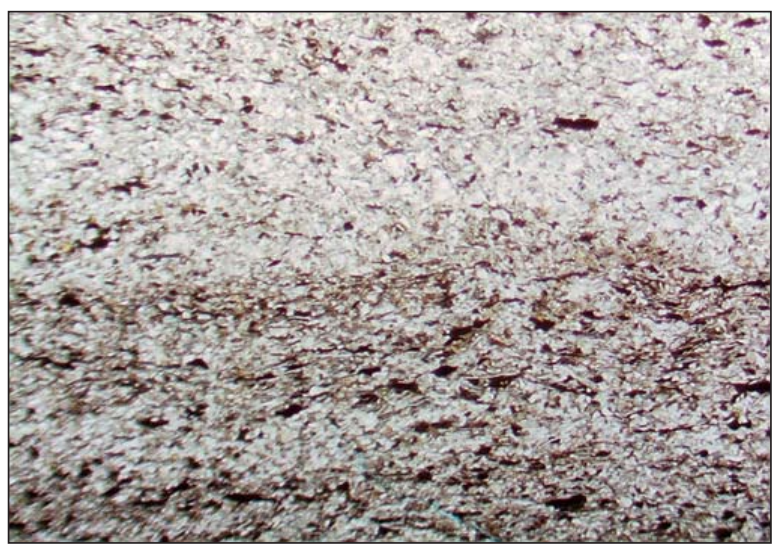

King13435a

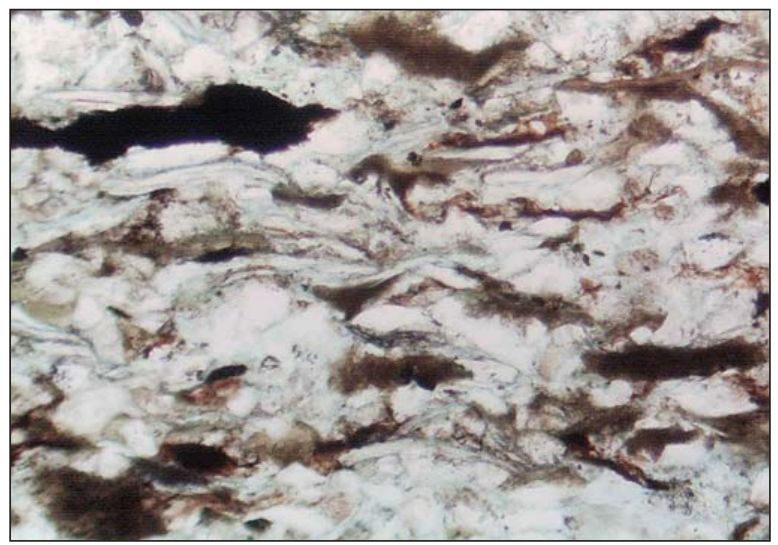

King13435c

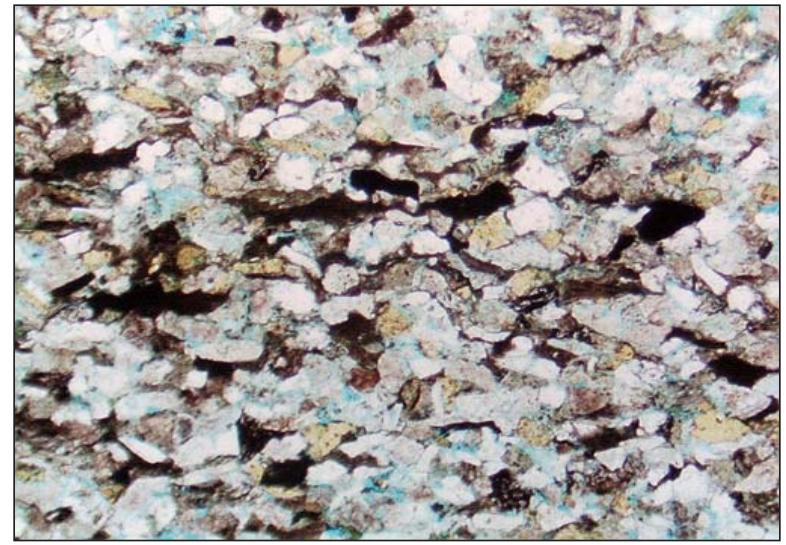

MGS1_5696b

${ }^{\mathrm{a}}$ Horizontal field of view across photograph in millimeters. 
Appendix 1. List of photomicrographs, by well and depth-continued

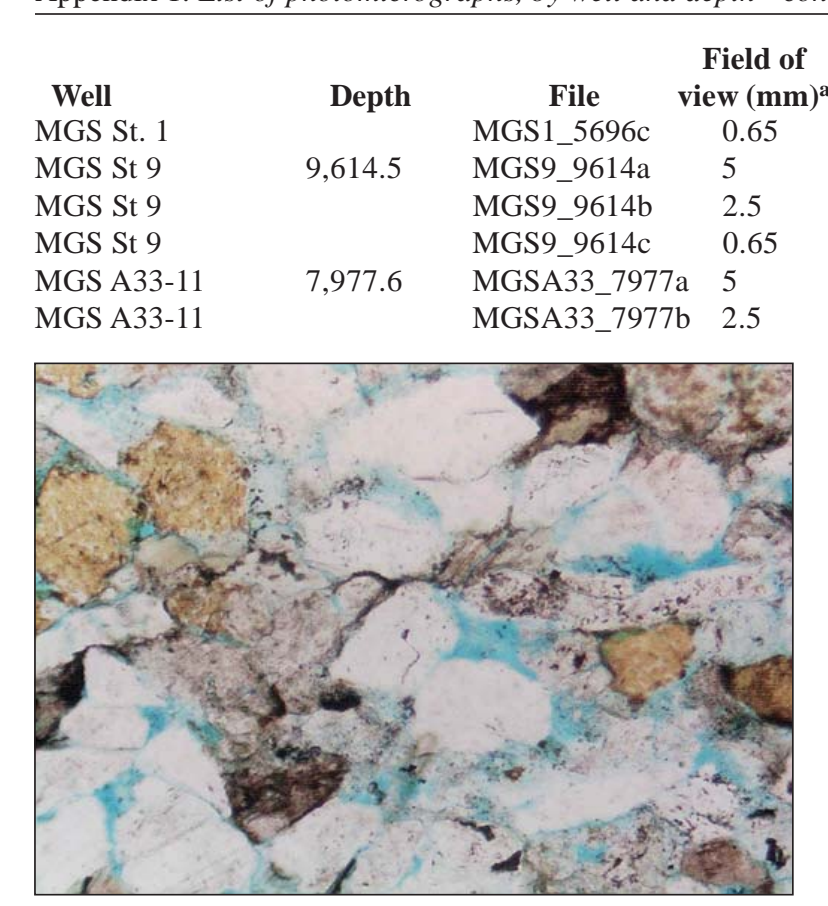

MGS1_5696c

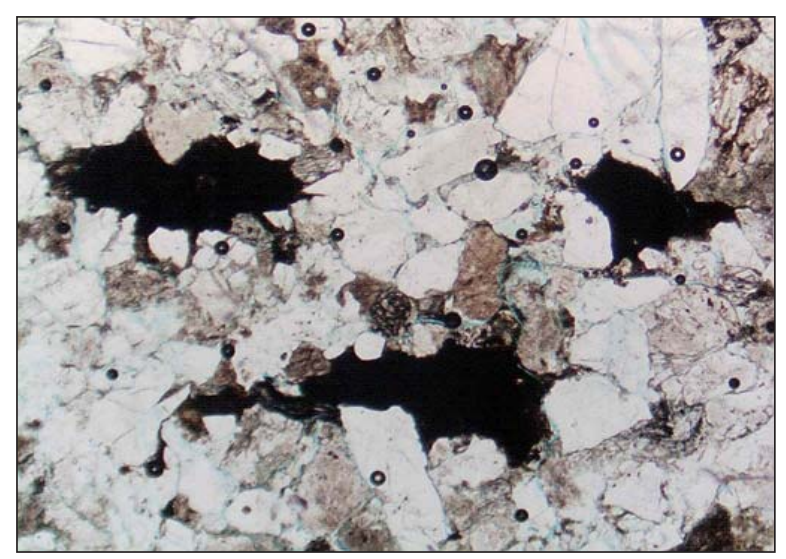

MGS9_9614b

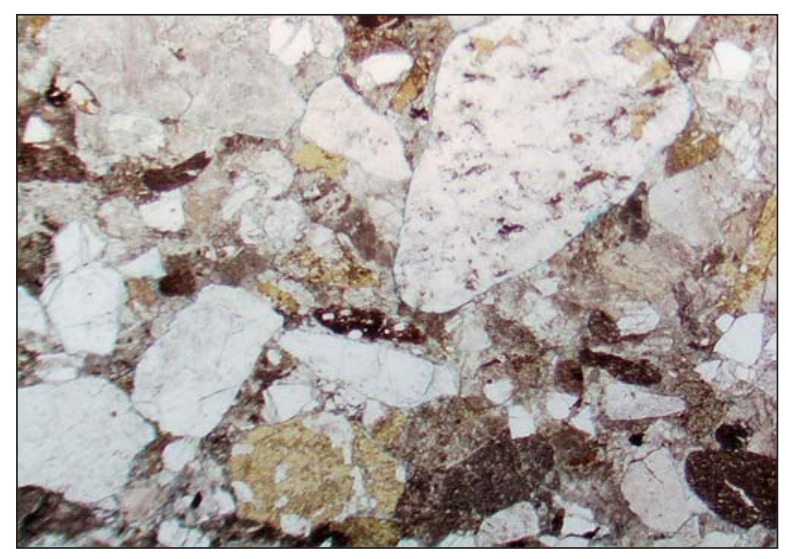

MGSA33_7977a

\section{Notes}

Small pores in very fine to fine sandstone

Dark expanded micritized biotite

Micritic biotite in compacted sandstone

Compacted biotite-potassium feldspar, metasedimentary lithic

Coarse calcareous tight sandstone

Metasedimentary-chert lithic fragments, volcanics

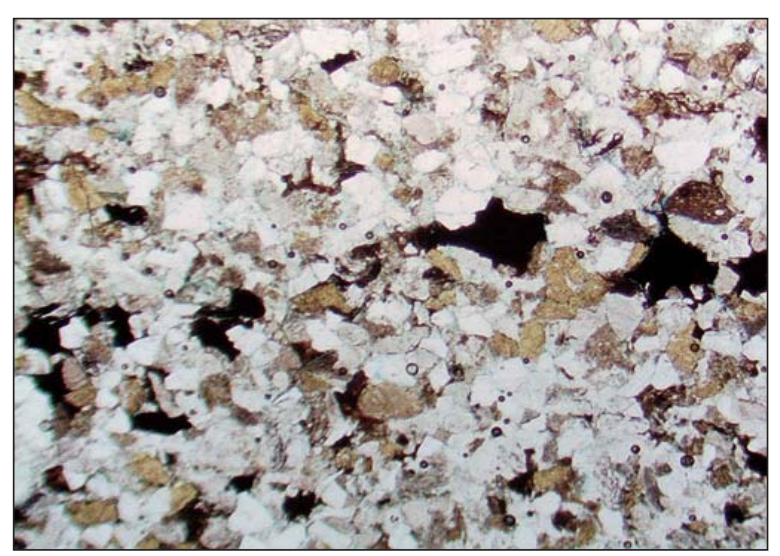

MGS9_9614a

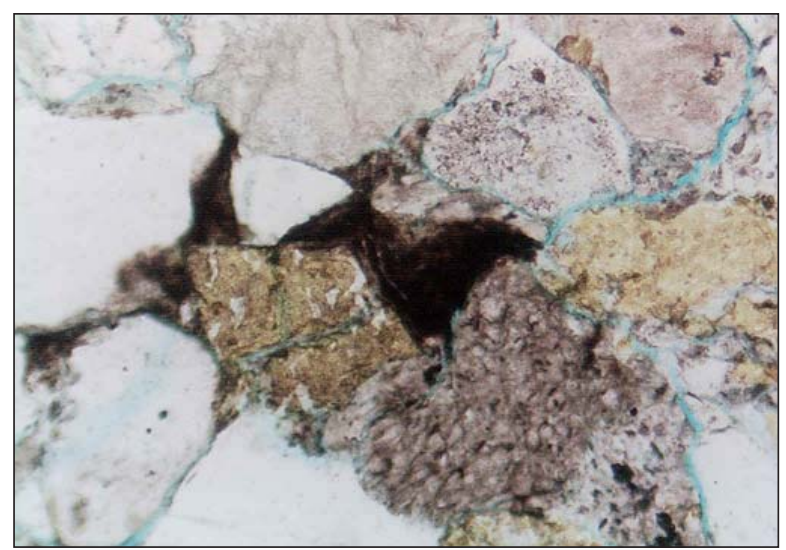

MGS9_9614c

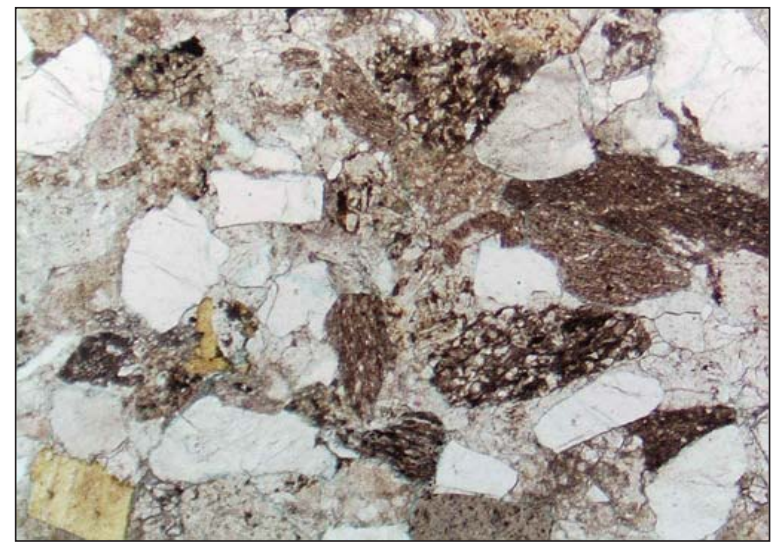

MGSA33_7977b

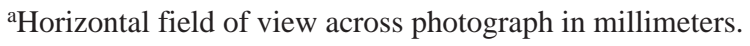


Appendix 1. List of photomicrographs, by well and depth-continued

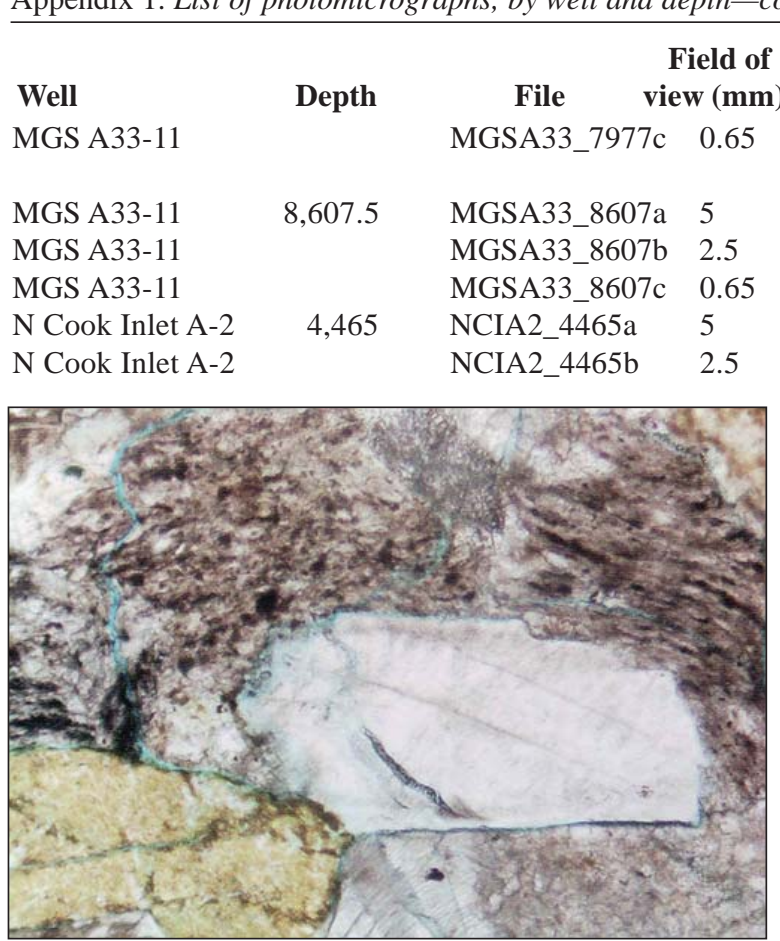

MGSA33_7977c

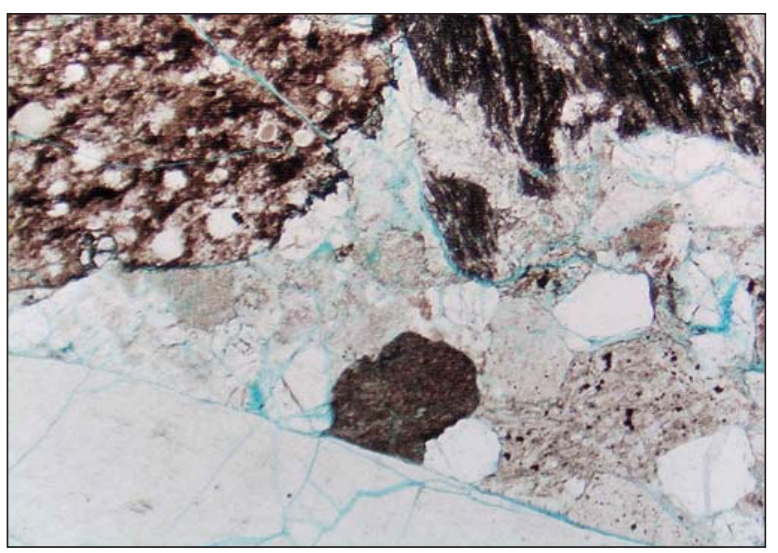

MGSA33_8607b

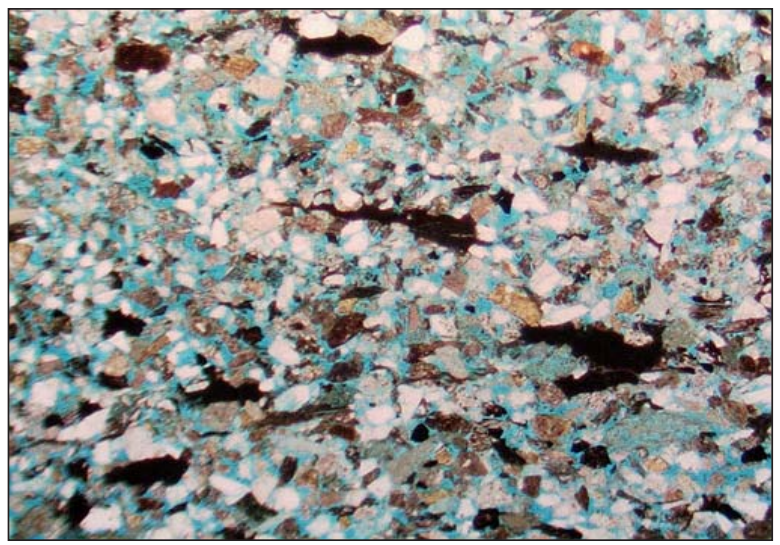

NCIA2_4465a

\section{Notes}

Metasedimentary lithic, potassium feldspar, plagioclase, in pore-filling sparry carbonate

Chert, metasedimentary lithic pebbles

Compacted sand matrix; chert

Metasedimentary lithic, microfractured grains

Micritic biotite in moderately open framework

Micritic biotite, intergranular pores

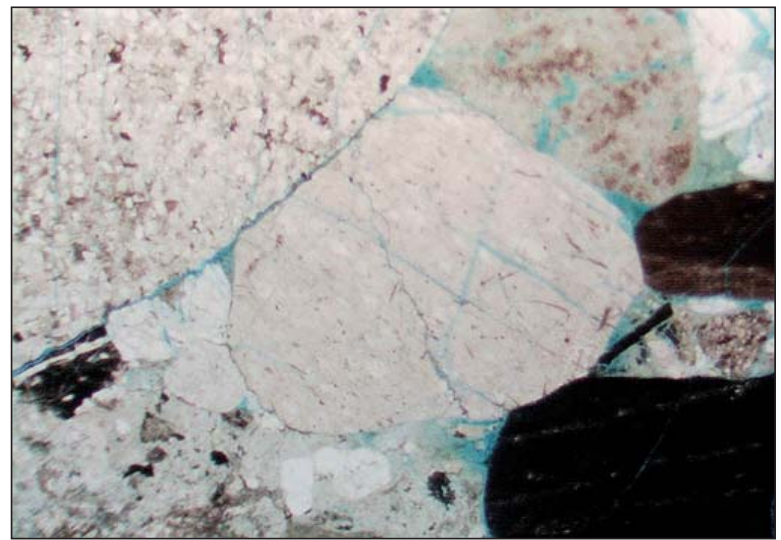

MGSA33_8607a

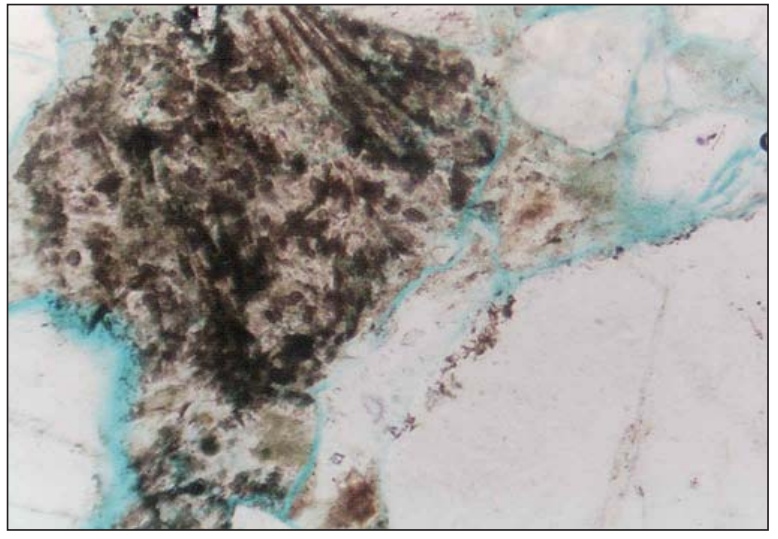

MGSA33_8607c

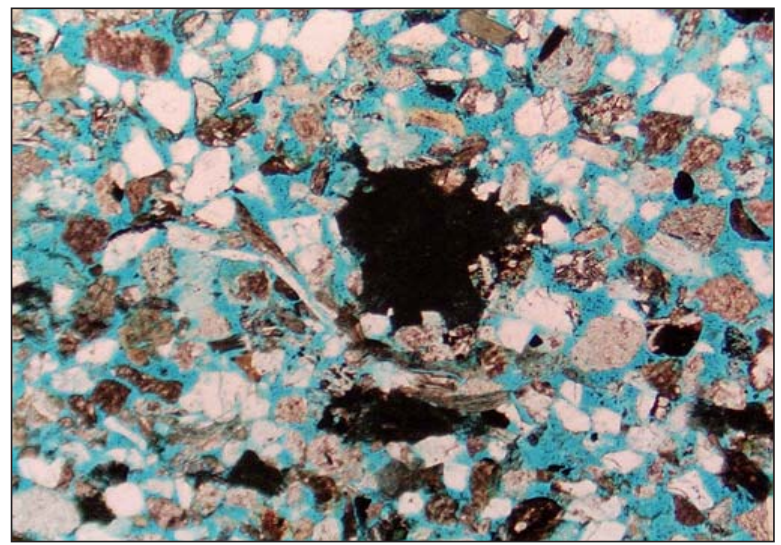

NCIA2_4465b

${ }^{a}$ Horizontal field of view across photograph in millimeters. 
Appendix 1. List of photomicrographs, by well and depth-continued

\begin{tabular}{lllll}
\hline & & \multicolumn{3}{c}{$\begin{array}{c}\text { Field of } \\
\text { View }(\mathbf{m m})^{\mathbf{a}}\end{array}$} \\
N Cook Inlet A-2 & Depth & \multicolumn{1}{c}{ File } & Notes \\
N Cook Inlet A-2 & 4,815 & NCIA2_4465c & 0.65 & Pumice fragment \\
N Cook Inlet A-2 & & NCIA2_4815a & 5 & Microporous shale \\
N Cook Inlet A-2 & & NCIA2_4815b & 2.5 & Microporous shale \\
PNC 14-2 & \multirow{2}{*}{4,580} & NCIA2_4815c & 0.65 & Microporous matrix \\
PNC 14-2 & & PNC142_4580a & 5 & Lignite-rich lamination \\
& & PNC142_4580b & 2.5 & Porous sandstone with lignitic laminations
\end{tabular}

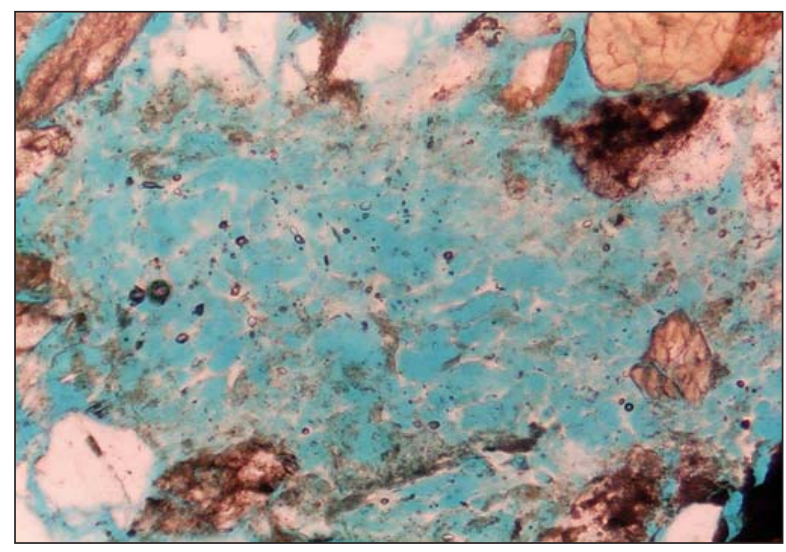

NCIA2_4465c

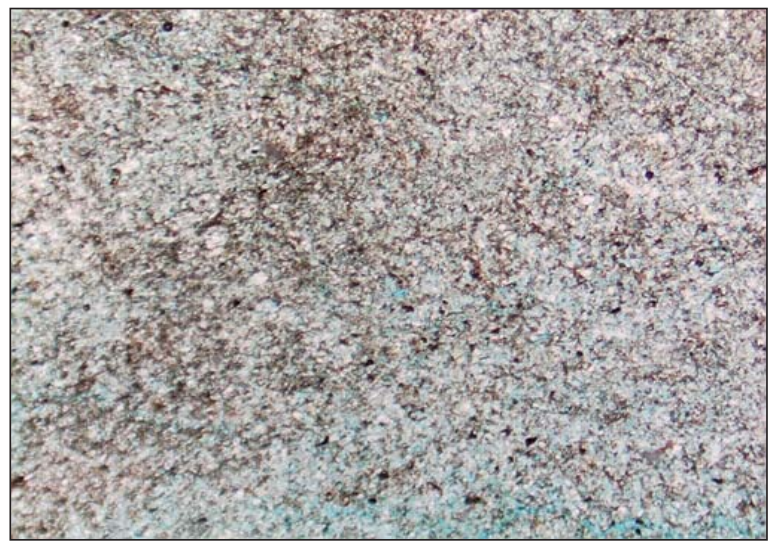

NCIA2_4815b

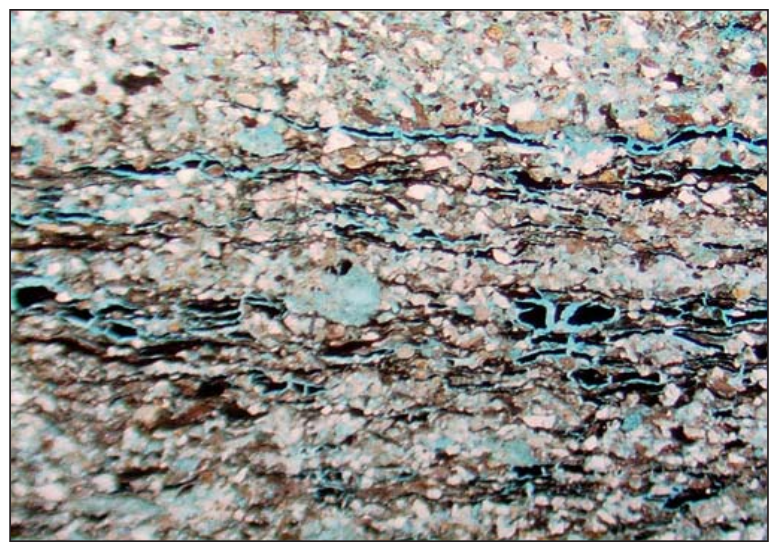

PNC142_4580a

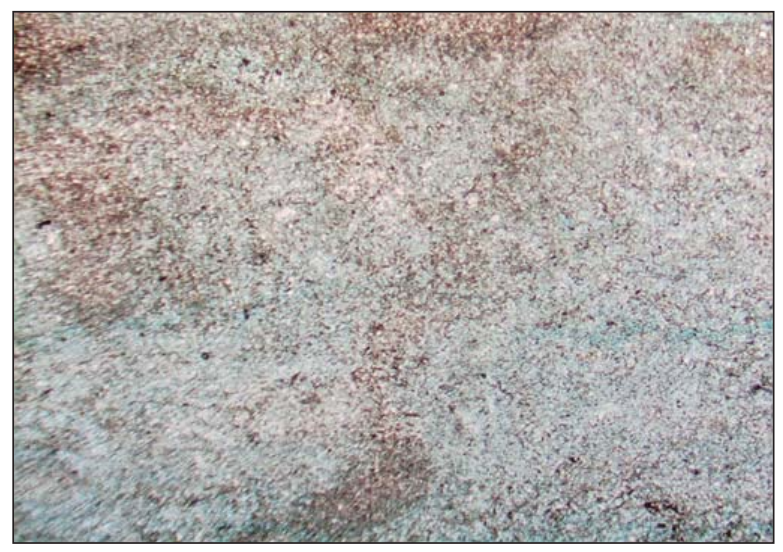

NCIA2_4815a

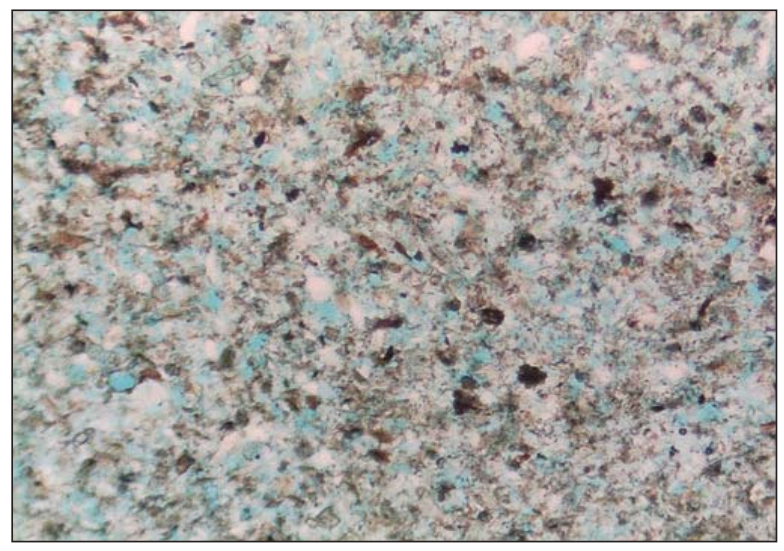

NCIA2_4815c

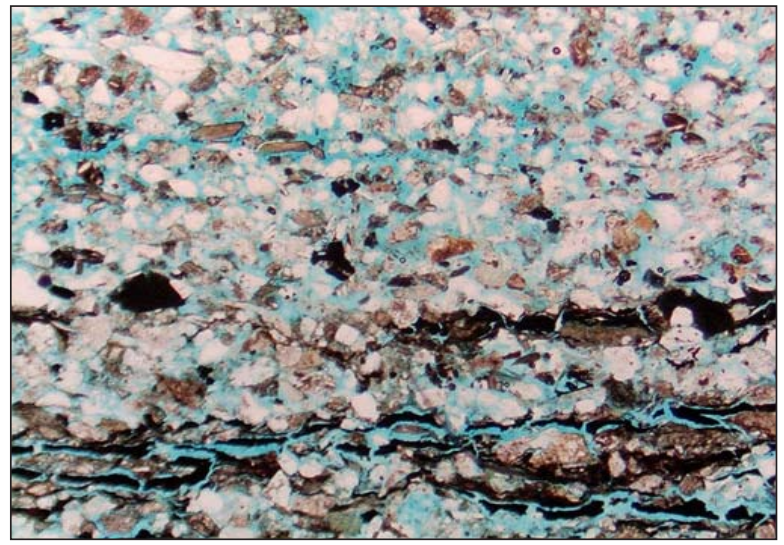

PNC142_4580b

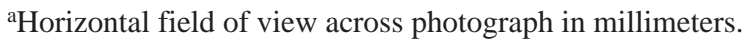


Appendix 1. List of photomicrographs, by well and depth-continued

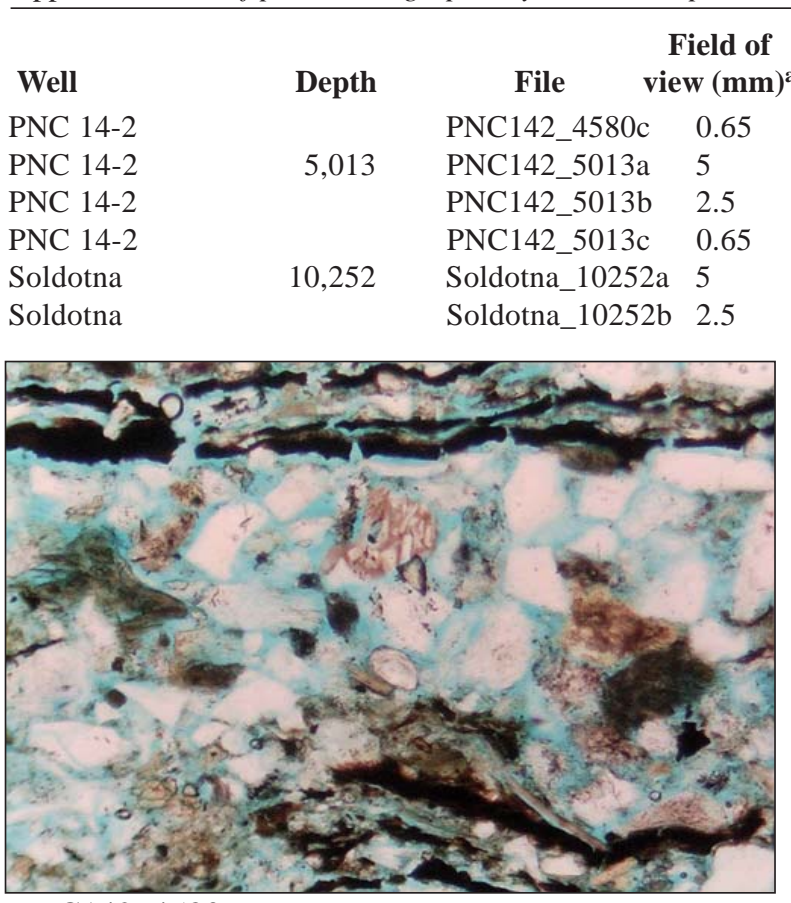

PNC142_4580c

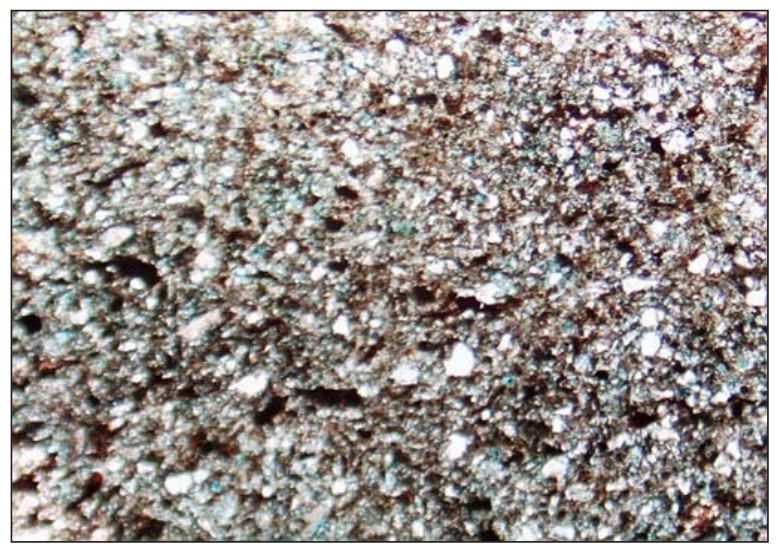

PNC142_5013b

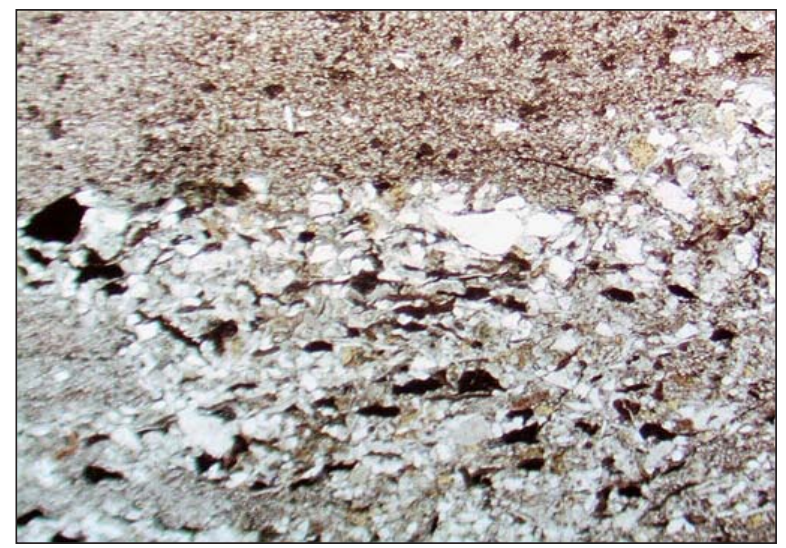

Soldotna_10252a
Notes

Lignite flakes in fine sandstone

Sandy, slightly lignitic shale

Microporous shale

Sandy, slightly lignitic microporous matrix

Sandstone lens in shale

Lignite flakes in silty shale

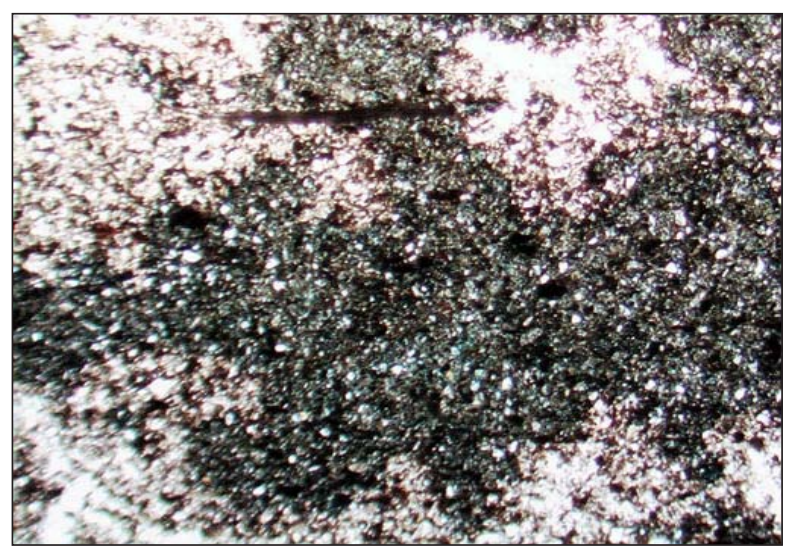

PNC142_5013a

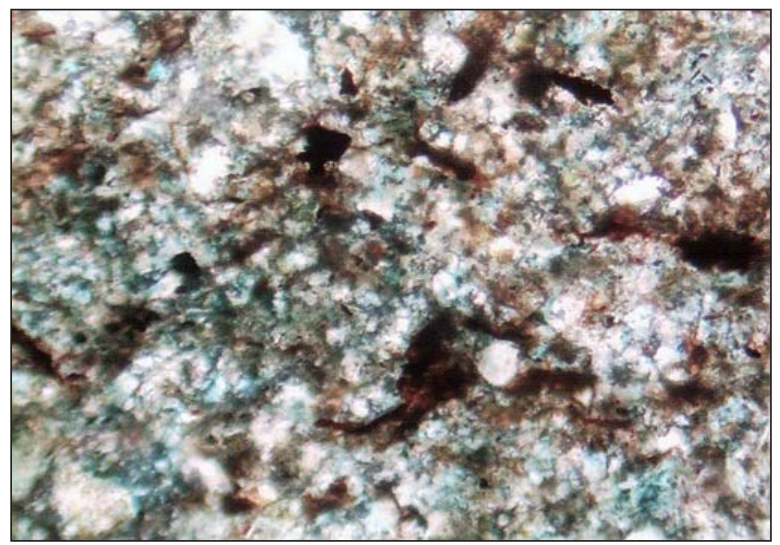

PNC142_5013c

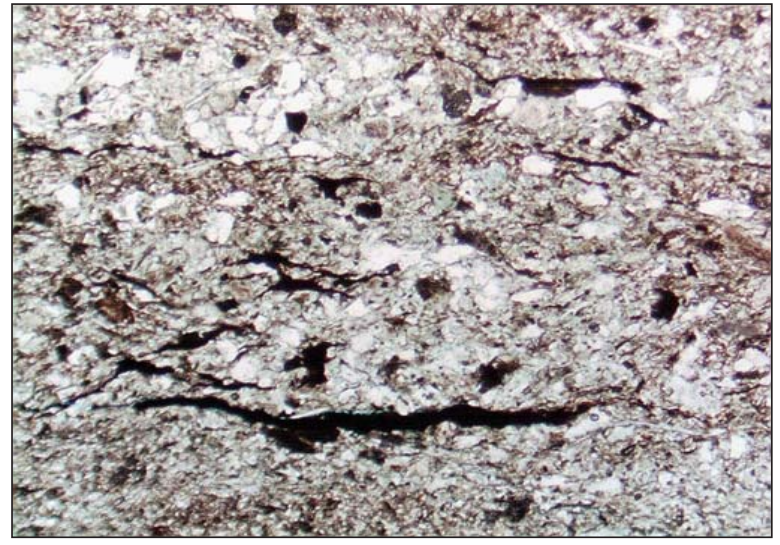

Soldotna_10252b

${ }^{a}$ Horizontal field of view across photograph in millimeters. 
Appendix 1. List of photomicrographs, by well and depth-continued

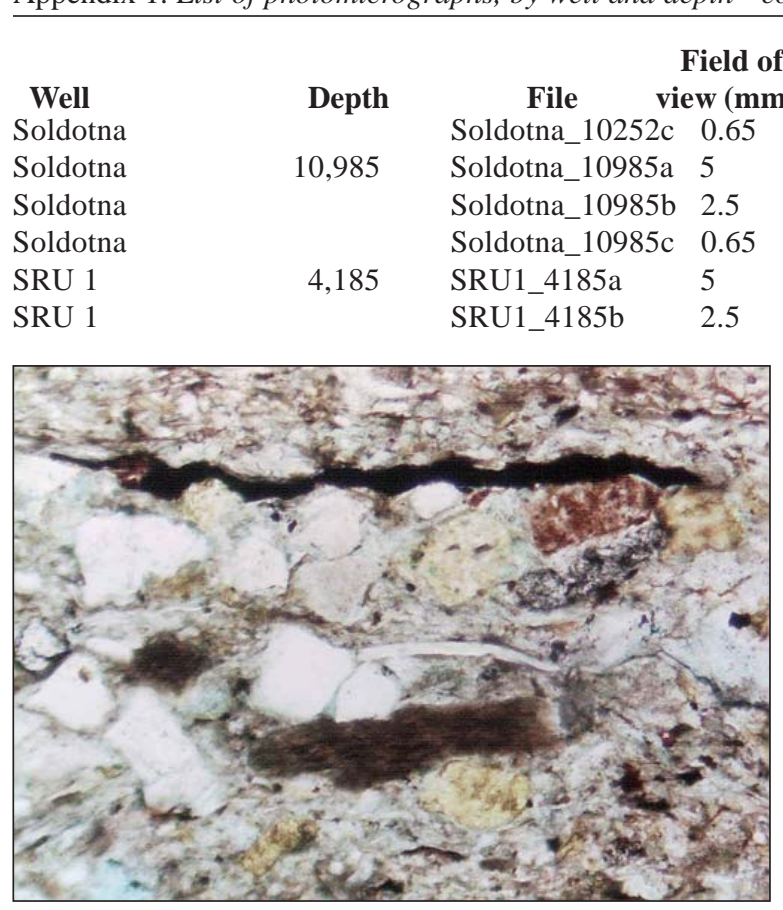

Soldotna_10252c

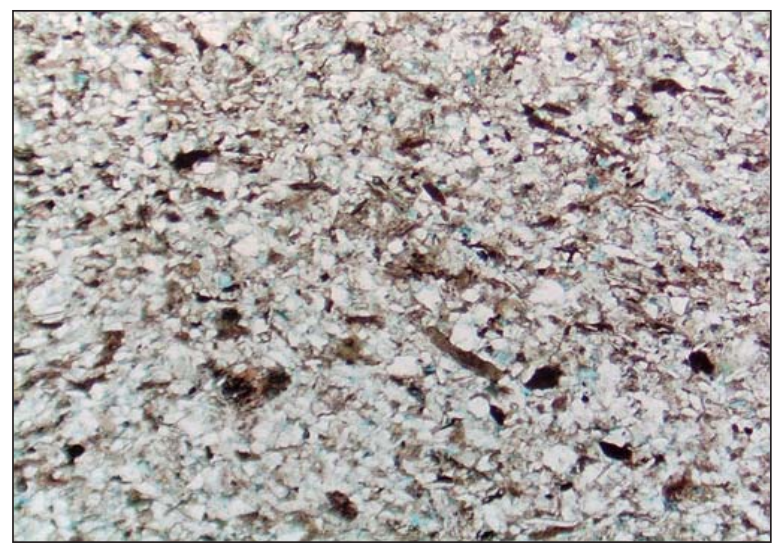

Soldotna_10985b

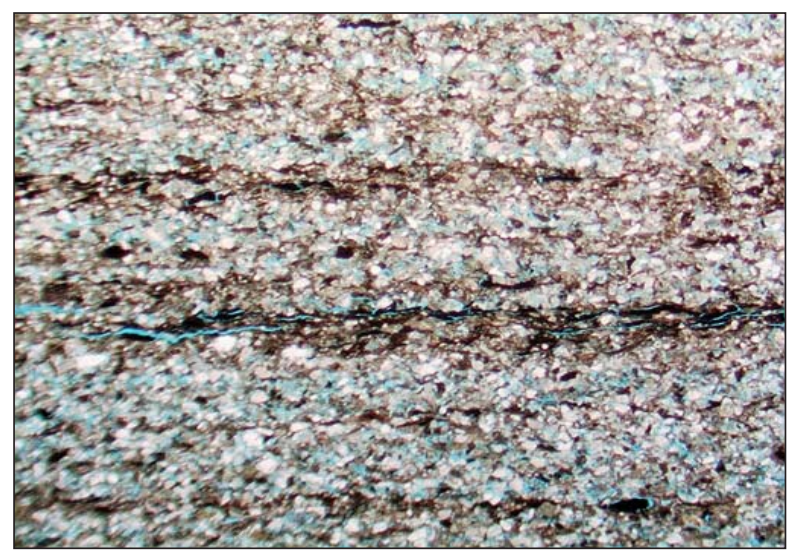

SRU1_4185a

\section{Notes}

Mica, organic material in sandstone lens

Outsized sand grains in laminated shale

Fine sandstone in contact with shale

Very fine to fine micaceous arkose

Shaly sandstone with lignitic laminations

Lignite; disrupted fabric

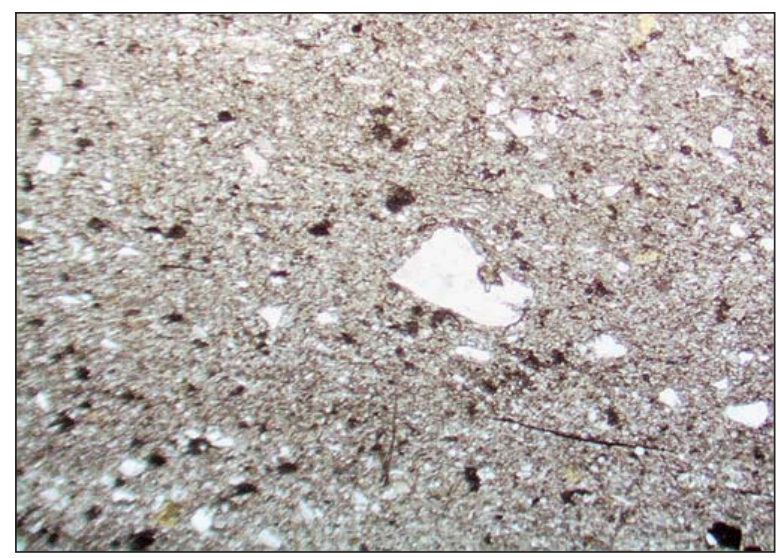

Soldotna_10985a

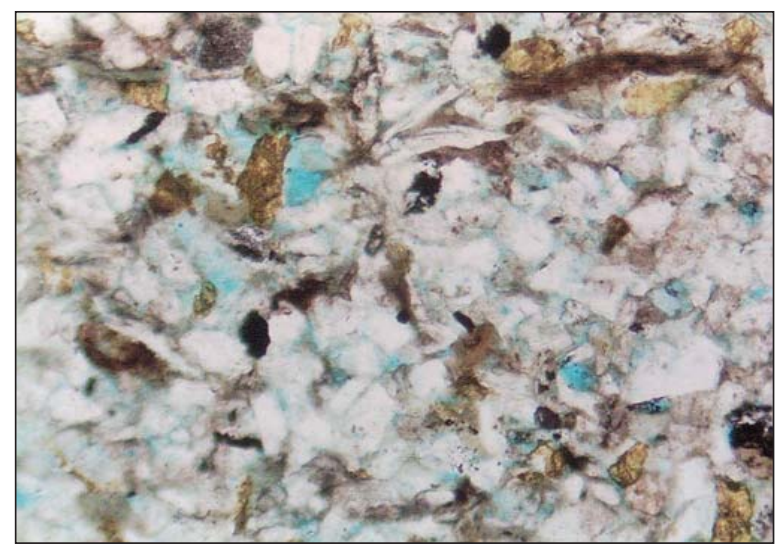

Soldotna_10985c

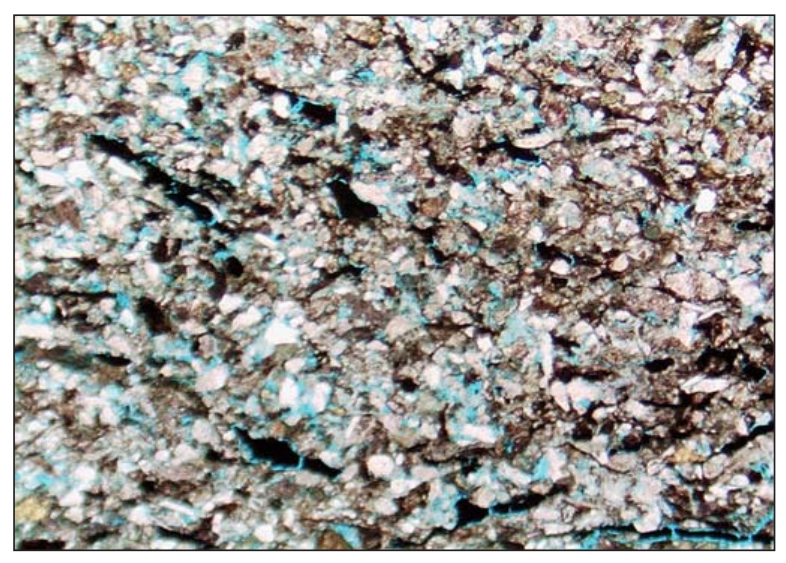

SRU1_4185b

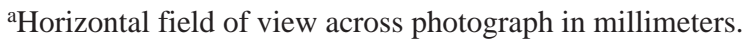


Appendix 1. List of photomicrographs, by well and depth-continued

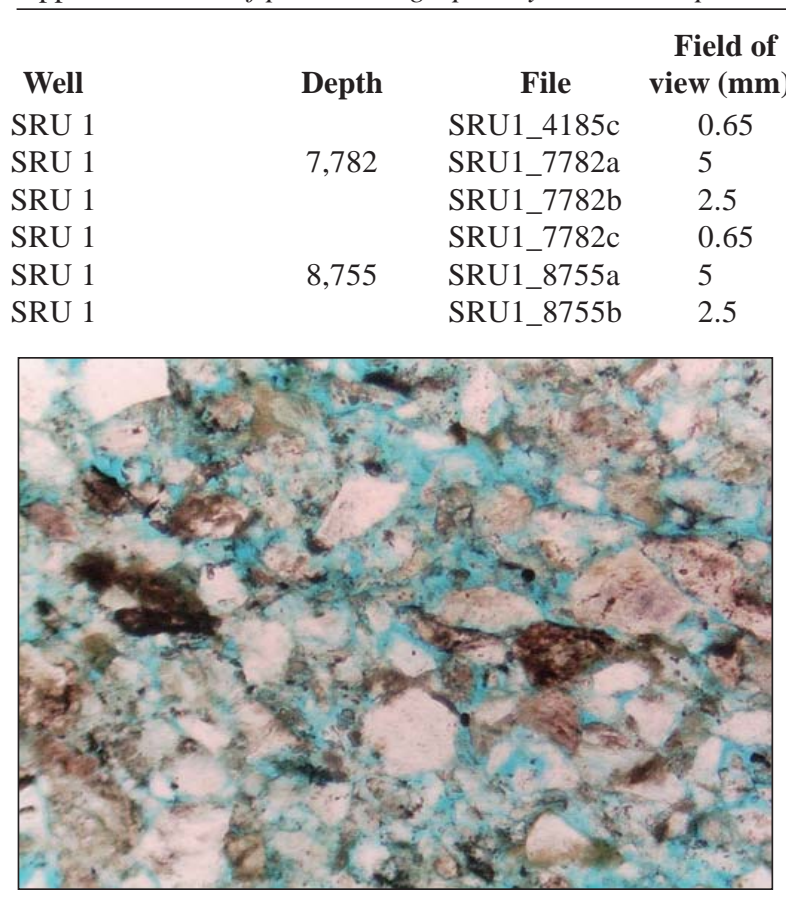

SRU1_4185c

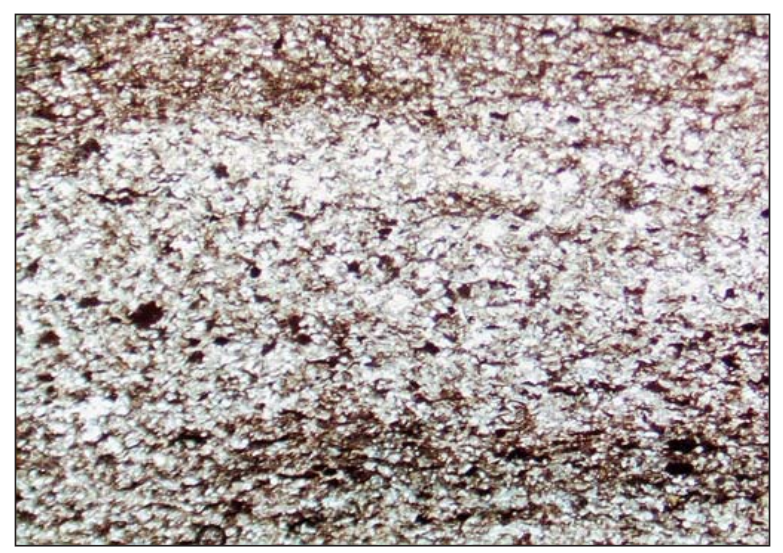

SRU1_7782b

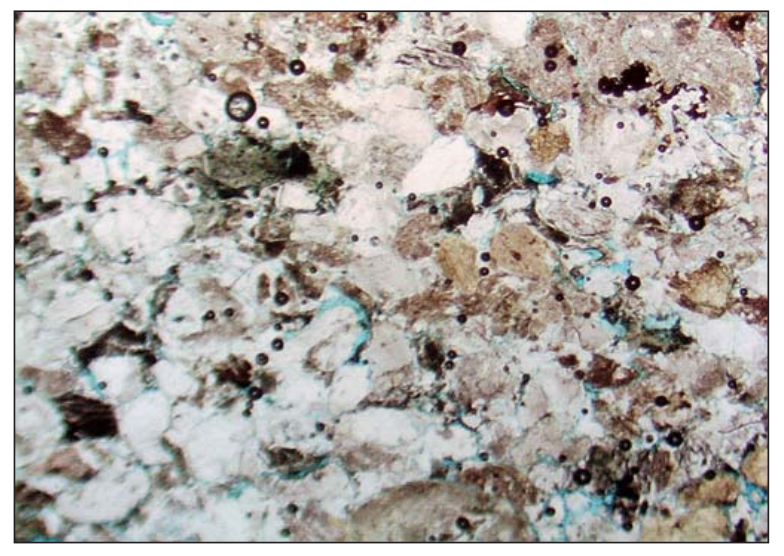

SRU1_8755a
Close-packed silty sandstone
Silty laminations in shale
Isolated silt ripple
Slightly lignitic micritic matrix
Close-packed coarse sandstone
Tight compacted sandstone

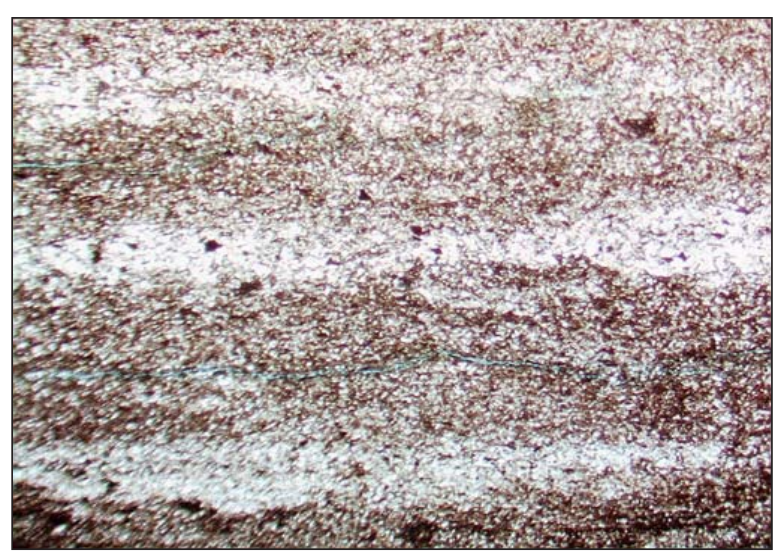

SRU1_7782a

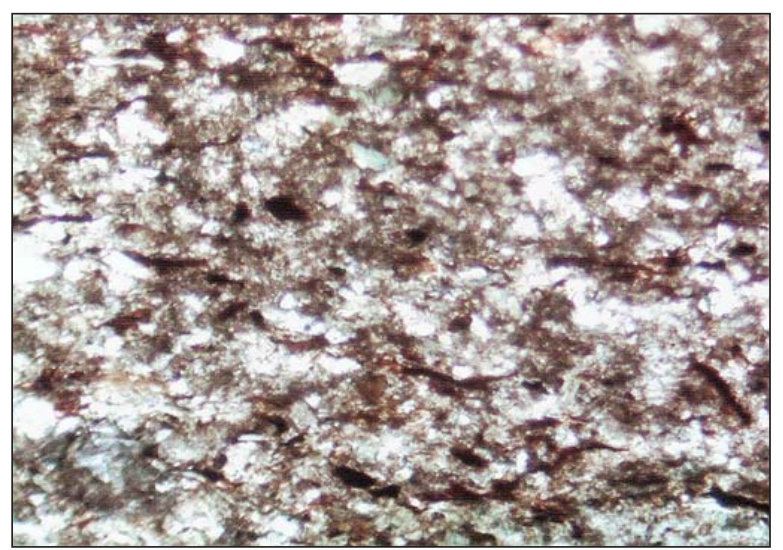

SRU1_7782c

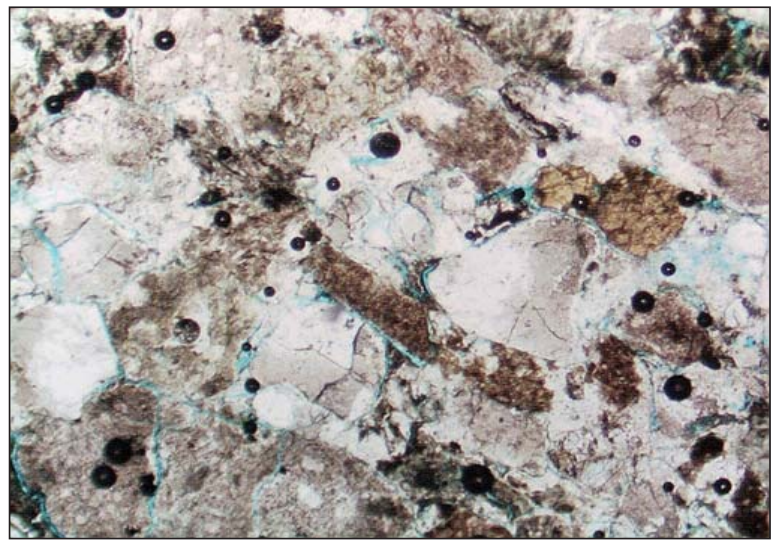

SRU1_8755b

${ }^{a}$ Horizontal field of view across photograph in millimeters. 
Appendix 1. List of photomicrographs, by well and depth-continued

\begin{tabular}{|c|c|c|c|c|}
\hline Well & Depth & File & $\begin{array}{c}\text { Field of } \\
\text { view }(\mathbf{m m})^{a}\end{array}$ & Notes \\
\hline SRU 1 & & SRU1_8755c & 0.65 & Pore-filling authigenic clay, metasedimentary lithic \\
\hline SRU 1 & 9,230 & SRU1_9230a & 5 & Intergranular pores in moderately open framework \\
\hline SRU 1 & & SRU1_9230b & 2.5 & $\begin{array}{l}\text { Metasedimentary lithic, quartz, plagioclase, potassium } \\
\text { feldspar, pores }\end{array}$ \\
\hline SRU 1 & & SRU1_9230c & 0.65 & Large intergranular pore \\
\hline SRU 1 & 10,816 & SRU1_10816a & 5 & Close-packed coarse sandstone \\
\hline SRU 1 & & SRU1_10816b & 2.5 & Clay-lined intergranular pore \\
\hline
\end{tabular}
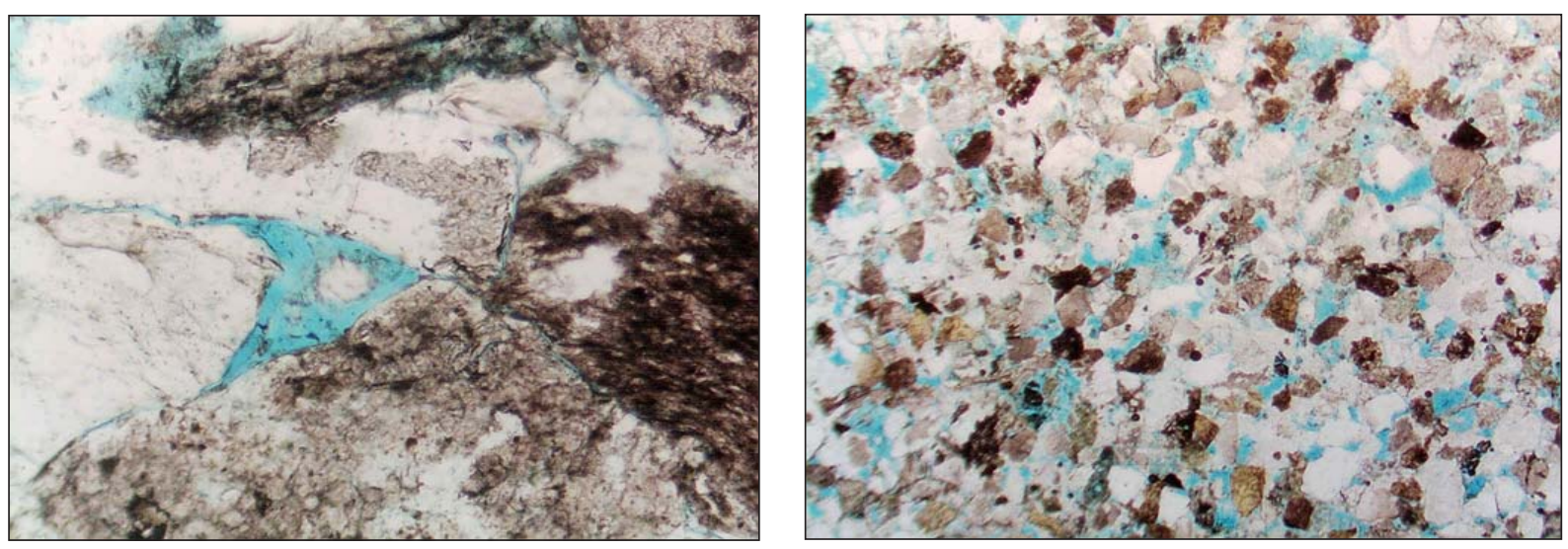

SRU1_8755c

\section{SRU1_9230a}

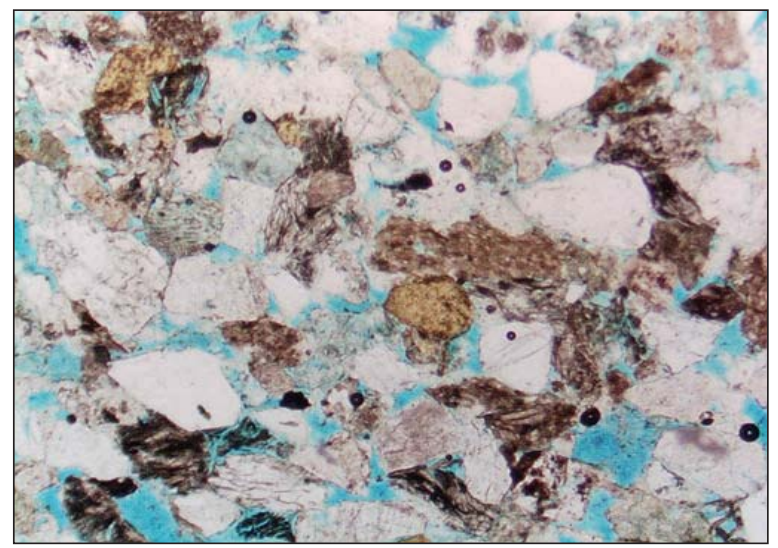

SRU1_9230b

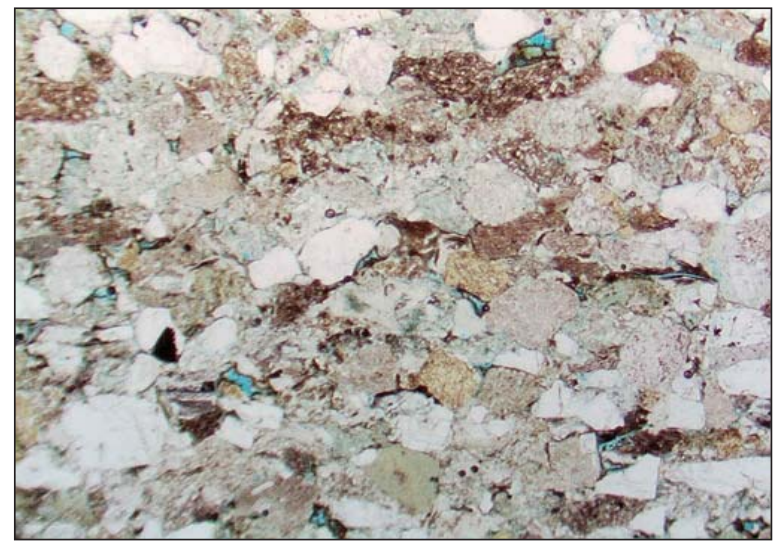

SRU1_10816a

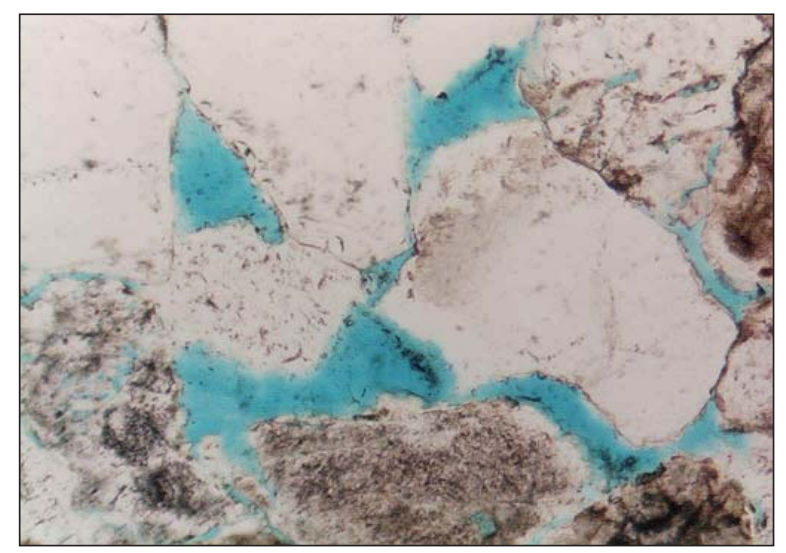

\section{SRU1_9230c}

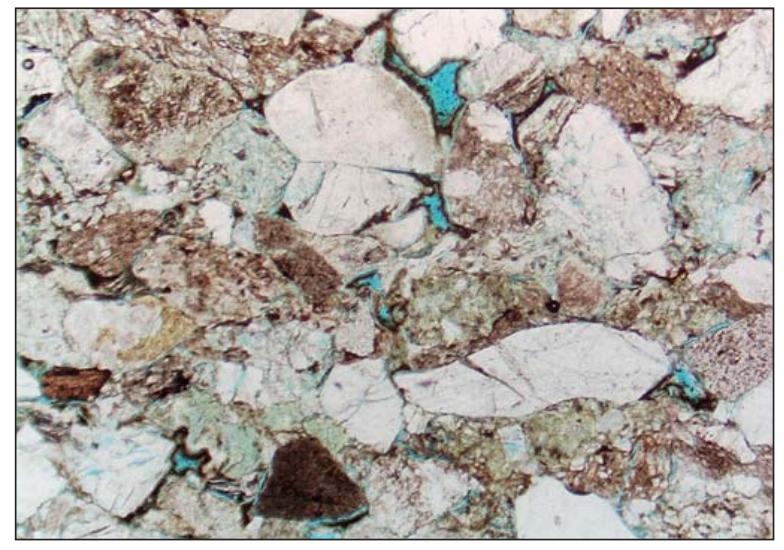

SRU1_10816b

${ }^{\text {a}}$ Horizontal field of view across photograph in millimeters. 
Appendix 1. List of photomicrographs, by well and depth-continued

\begin{tabular}{|c|c|c|c|c|}
\hline Well & Depth & File & $\begin{array}{c}\text { Field of } \\
\text { view }(\mathbf{m m})^{\mathrm{a}}\end{array}$ & Notes \\
\hline SRU 1 & & SRU1_10816c & 0.65 & Pore-lining clay \\
\hline SRU 2 & 4,363 & SRU2_4363a & 5 & Tight, coarse, calcareous sandstone \\
\hline SRU 2 & & SRU2_4363b & 2.5 & $\begin{array}{l}\text { Quartz, chert-metasedimentary lithic in calcareous } \\
\text { sandstone }\end{array}$ \\
\hline SRU 2 & & SRU2_4363c & 0.65 & Chert, metasedimentary lithic; carbonate cement \\
\hline SRU 2 & 10,875 & SRU2_10875a & 5 & Shale wisp in micaceous sandstone \\
\hline SRU 2 & & SRU2_10875b & 2.5 & Common biotite, muscovite \\
\hline
\end{tabular}

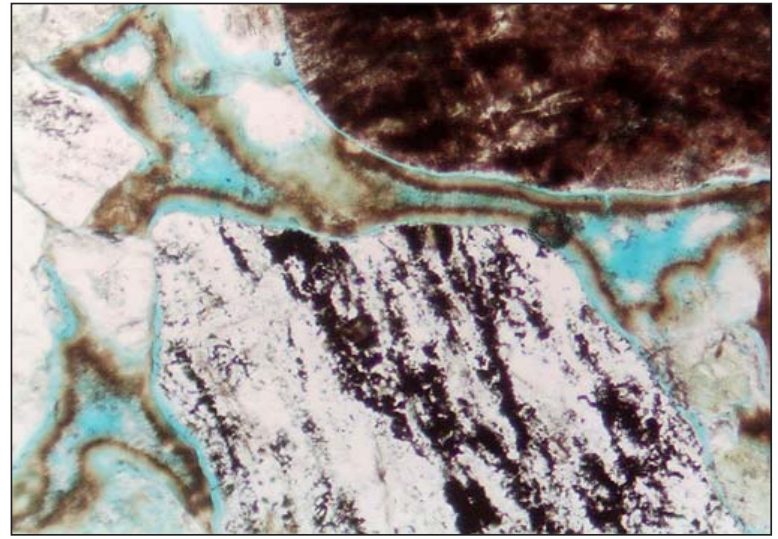

SRU1_10816c

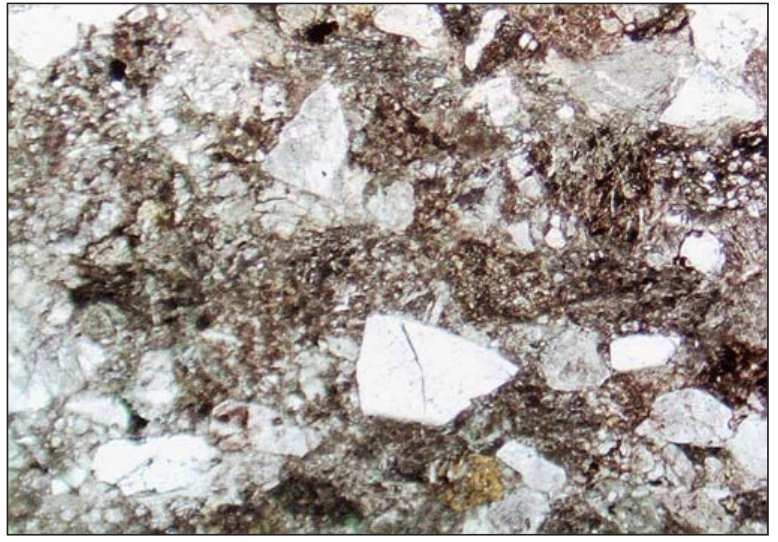

SRU2_4363b

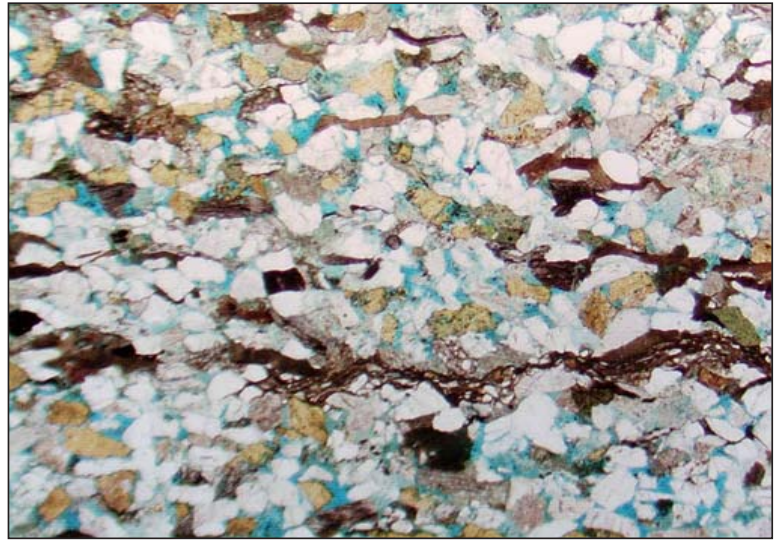

SRU2_10875a

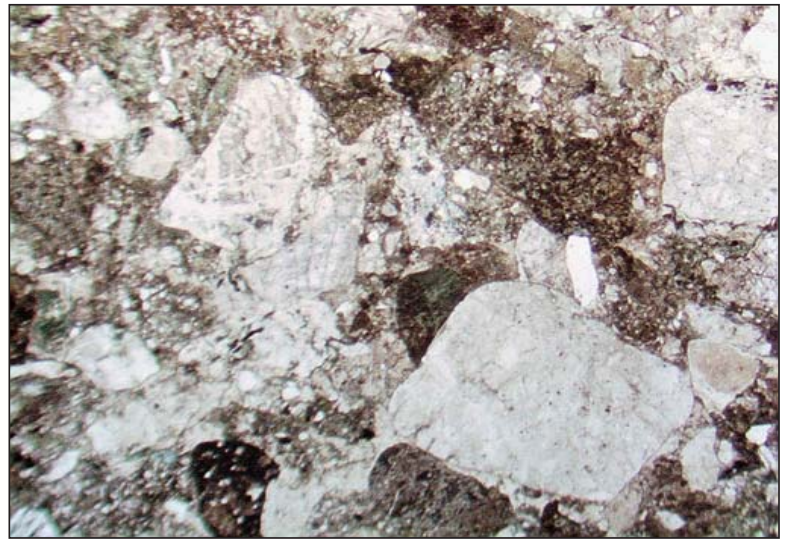

SRU2_4363a

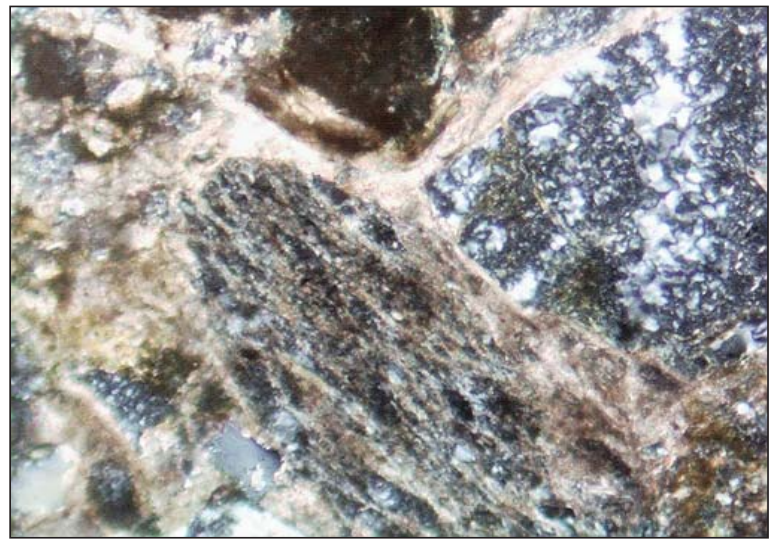

SRU2_4363c

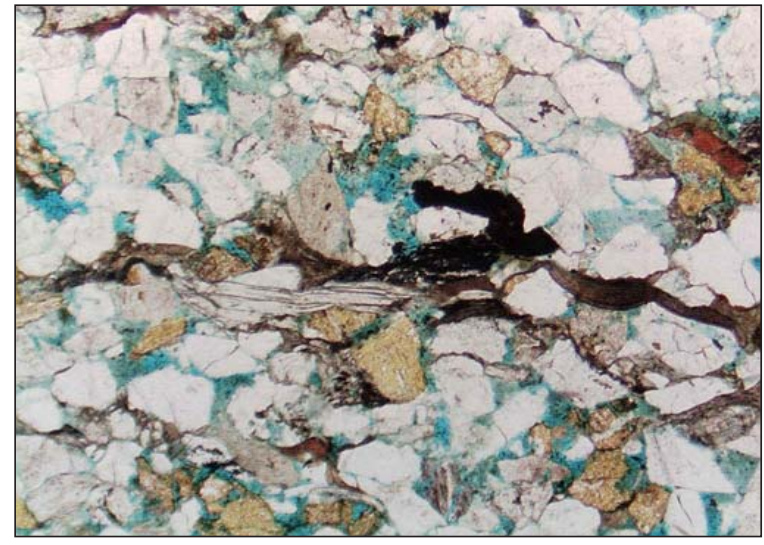

SRU2_10875b

${ }^{\mathrm{a}}$ Horizontal field of view across photograph in millimeters. 
Appendix 1. List of photomicrographs, by well and depth-continued

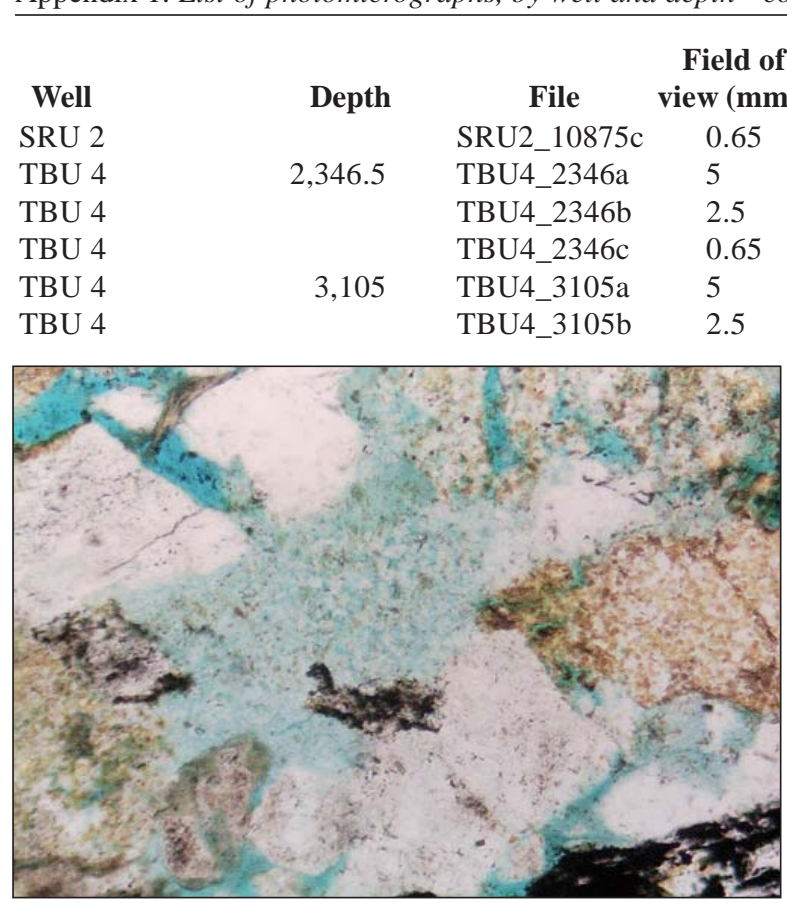

SRU2_10875c

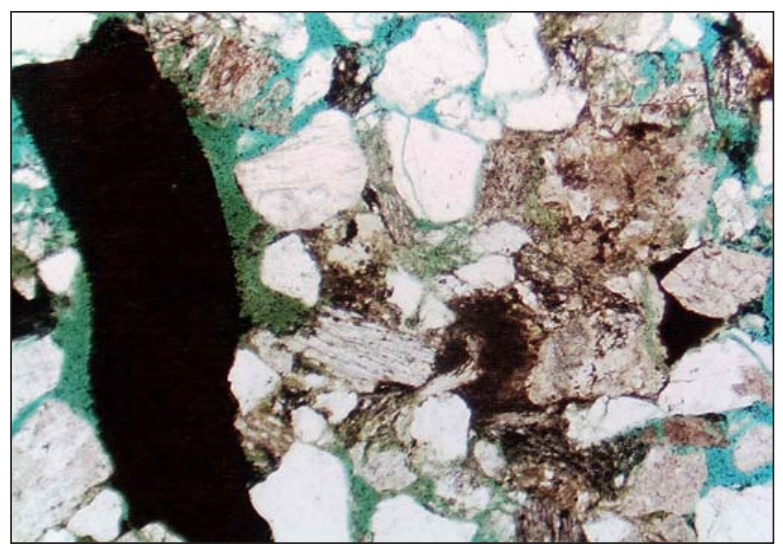

TBU4_2346b

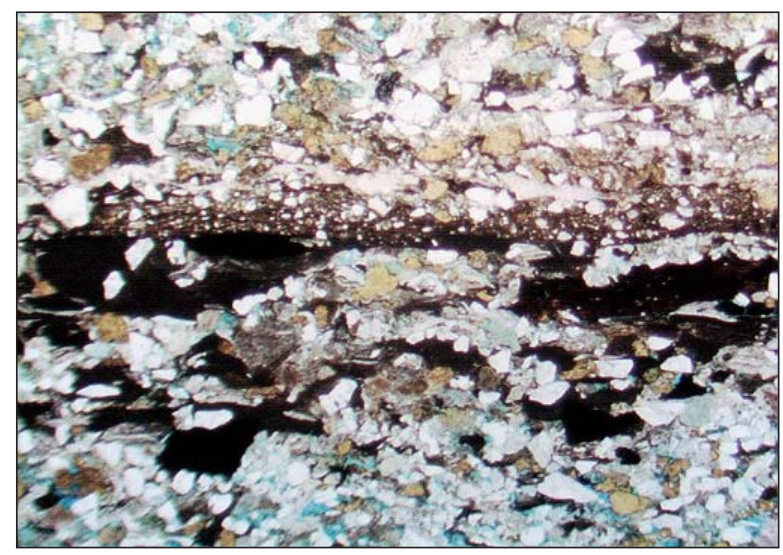

TBU4_3105a
Notes

Quartz, potassium feldspar, kaolinite

Large micritic biotite

Metasedimentary lithic, micritic biotite

Metasedimentary lithic, potassium feldspar

Mica, organic material, rip-ups

Compaction, micritic biotite

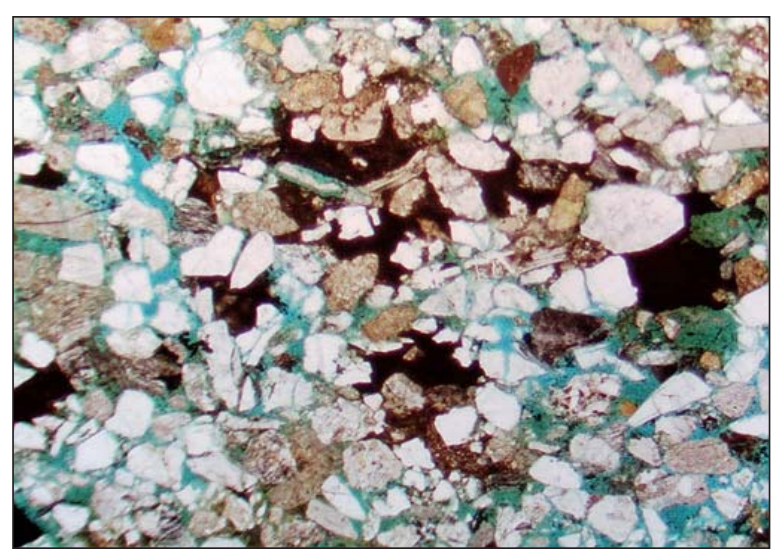

TBU4_2346a

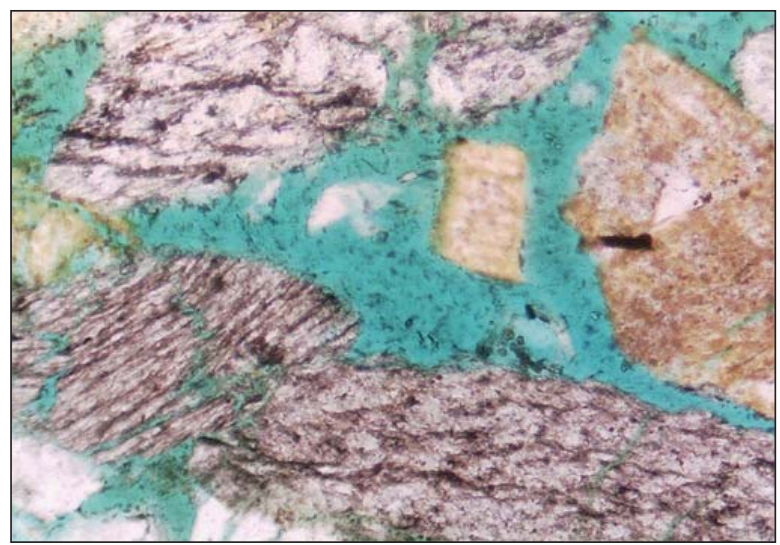

TBU4_2346c

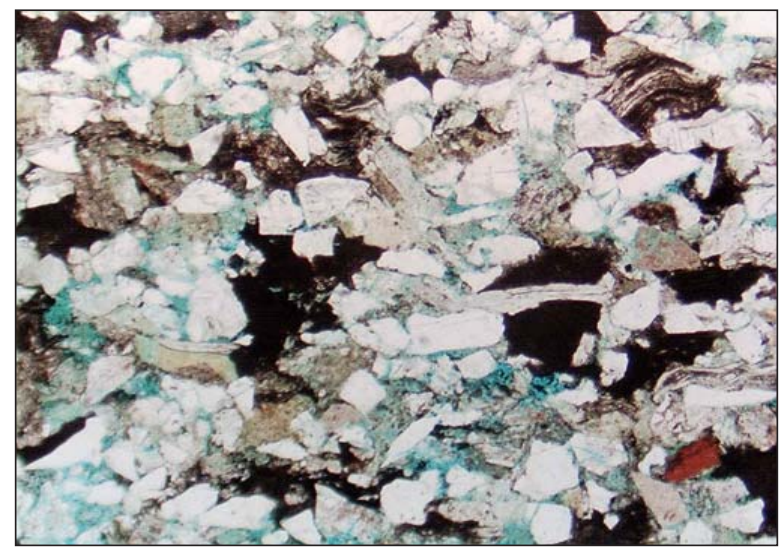

TBU4_3105b

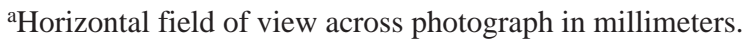


Appendix 1. List of photomicrographs, by well and depth—continued

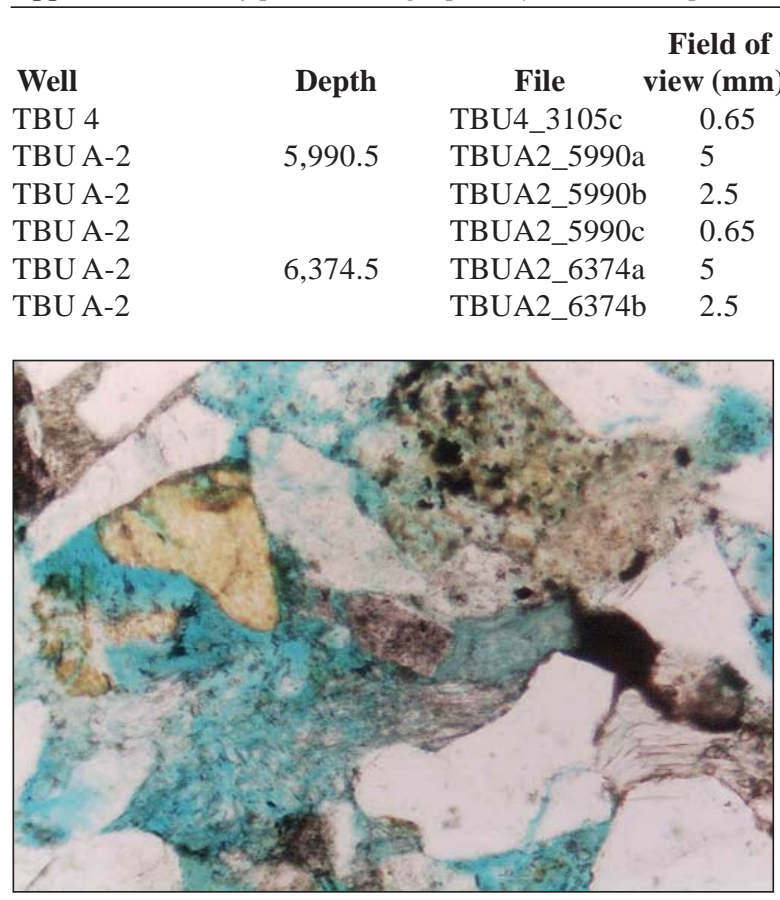

TBU4_3105c

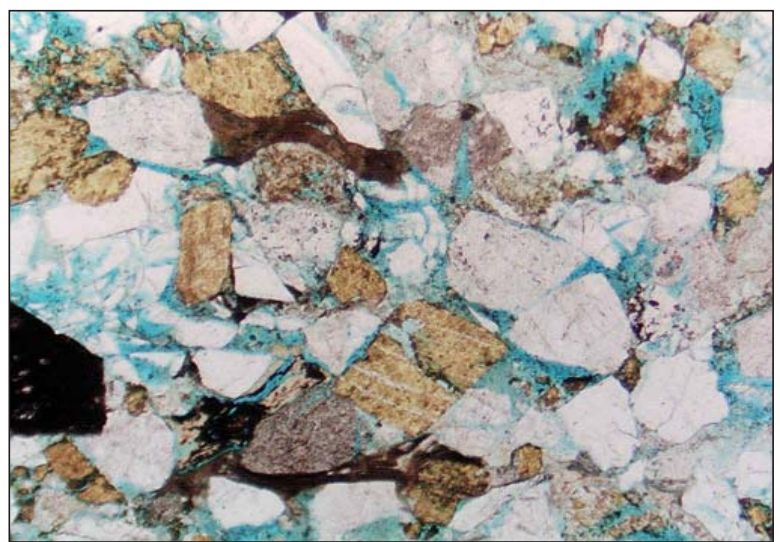

TBUA2_5990b

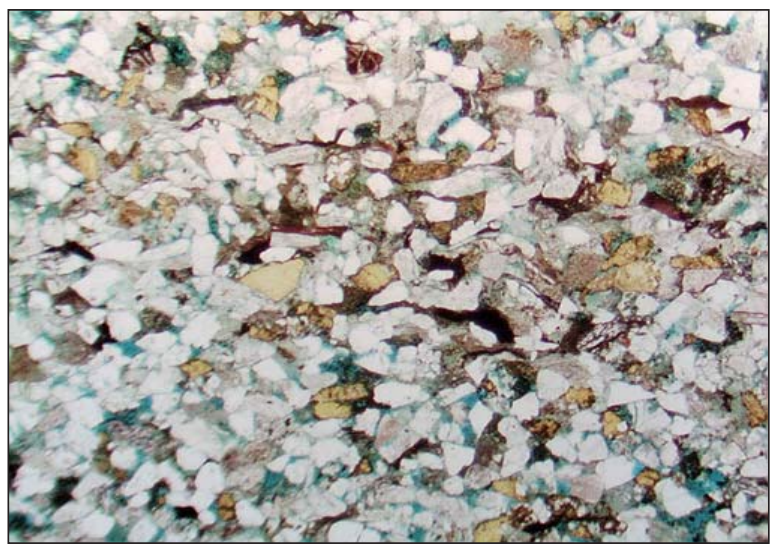

TBUA2_6374a

\section{Notes}

Squashed ductiles, microporosity

Compaction, fractured grains

Biotite; fractured grains

Porosity within fractured grains

Close-packed micaceous arkose

Intergranular \& intragranular pores; ductile grains

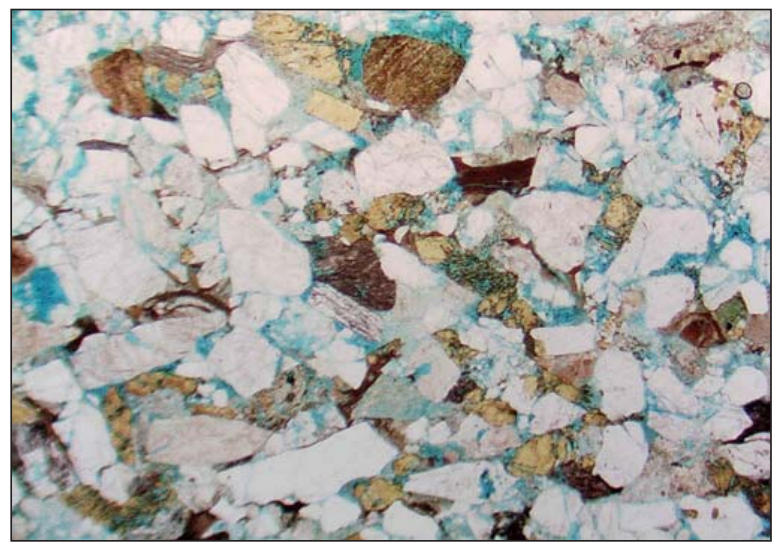

TBUA2_5990a

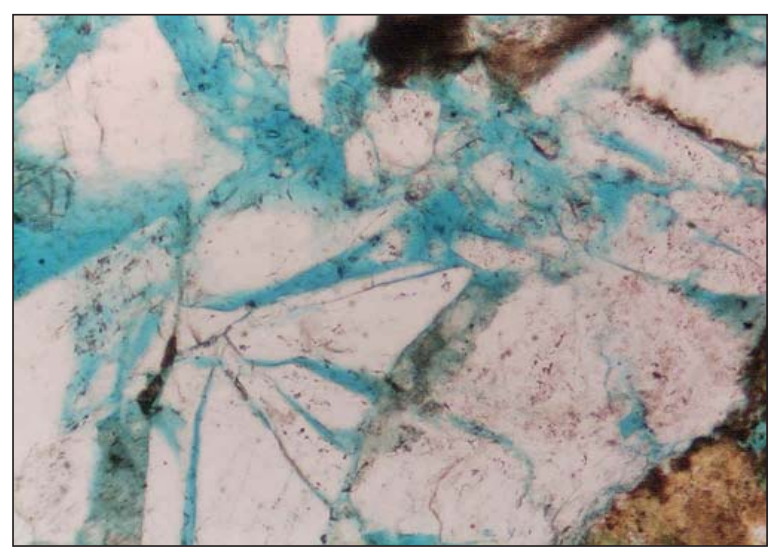

TBUA2_5990c

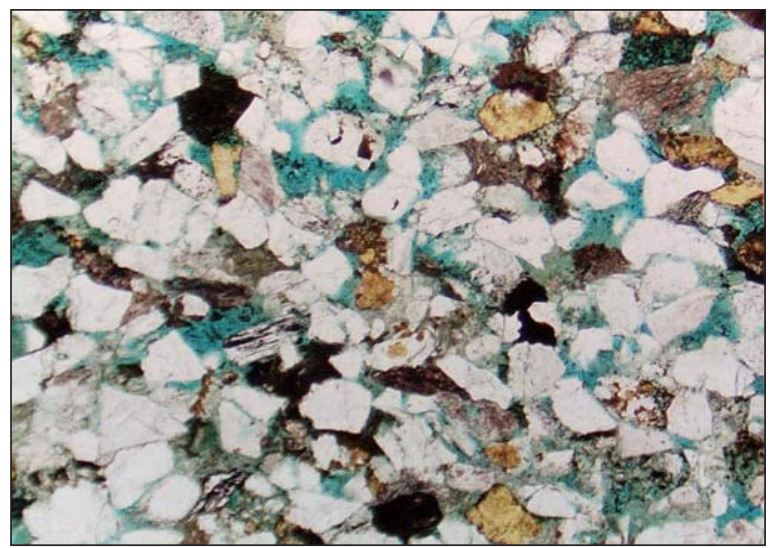

TBUA2_6374b

${ }^{\mathrm{a}}$ Horizontal field of view across photograph in millimeters. 
Appendix 1. List of photomicrographs, by well and depth-continued

\begin{tabular}{cccll} 
& & \multicolumn{3}{c}{ Field of } \\
Well & Depth & \multicolumn{1}{c}{ File } & view $(\mathbf{m m})^{\mathbf{a}}$ & \multicolumn{1}{c}{ Notes } \\
TBU A-2 & & TBUA2_6374c & 0.65 & Potassium feldspar, metasedimentary lithic, kaolinite \\
TBU A-7 & $3,850.5$ & TBUA7_3850a & 5 & Meta-sandstone clast \\
TBU A-7 & & TBUA7_3850b & 2.5 & Chert, metasedimentary lithic \\
TBU A-7 & & TBUA7_3850c & 0.65 & Pore-filling kaolinite \\
TBU A-7 & 4,861 & TBUA7_4861a & 5 & Micaceous lamina in porous sandstone \\
TBU A-7 & & TBUA7_4861b & 2.5 & Metasedimentary lithic, mica
\end{tabular}

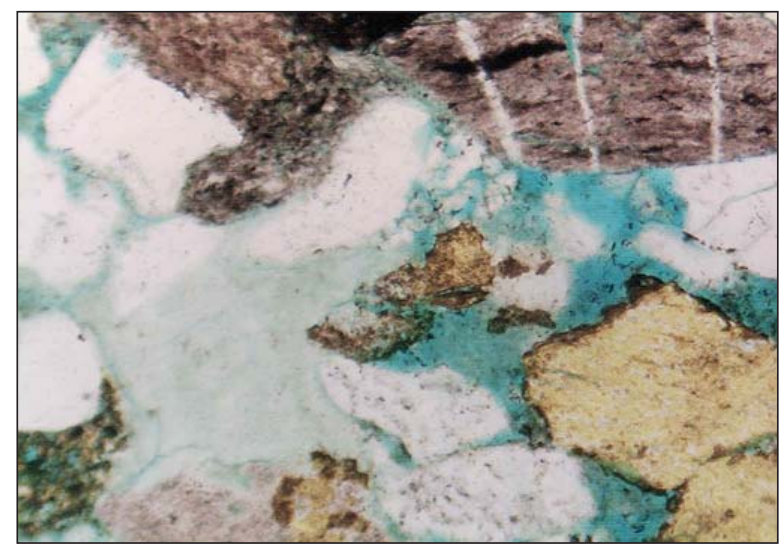

TBUA2_6374c

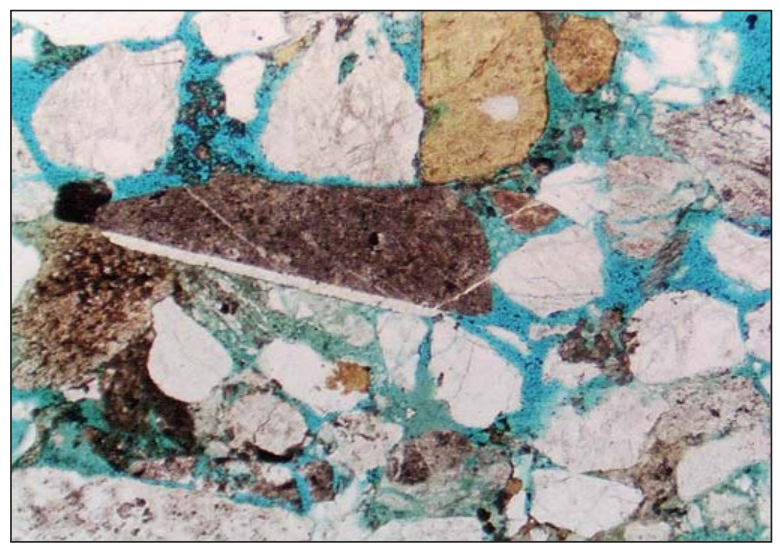

TBUA7_3850b

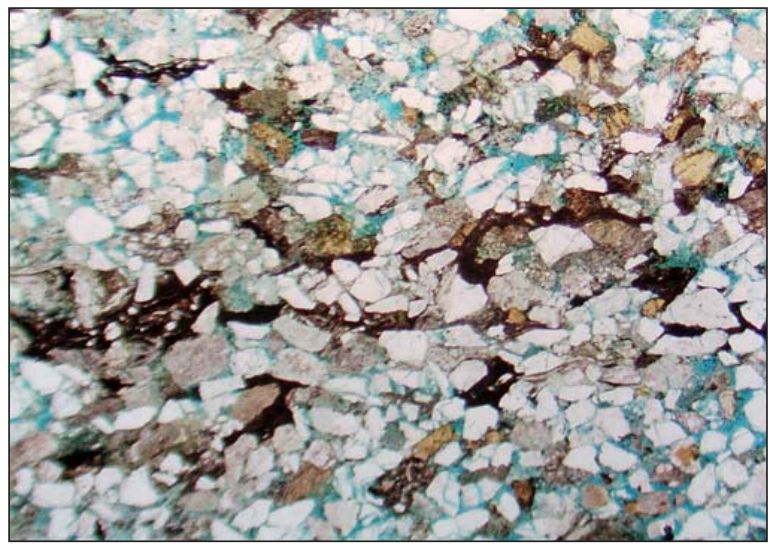

TBUA7_4861a

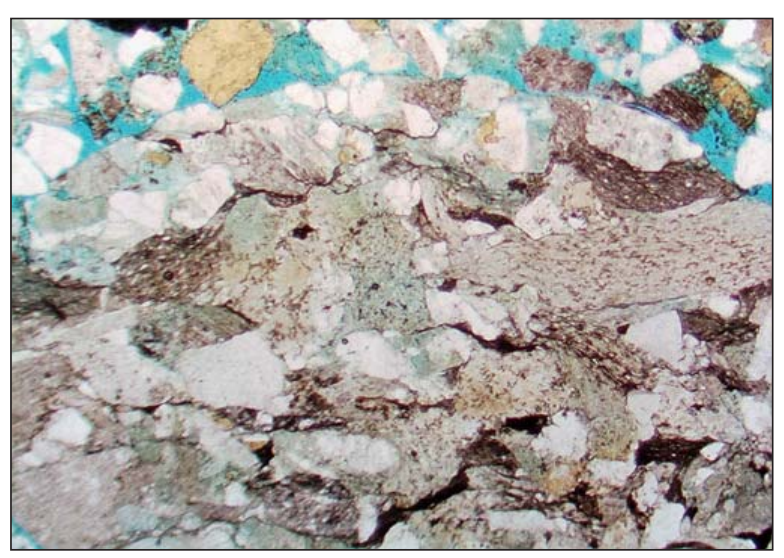

TBUA7_3850a

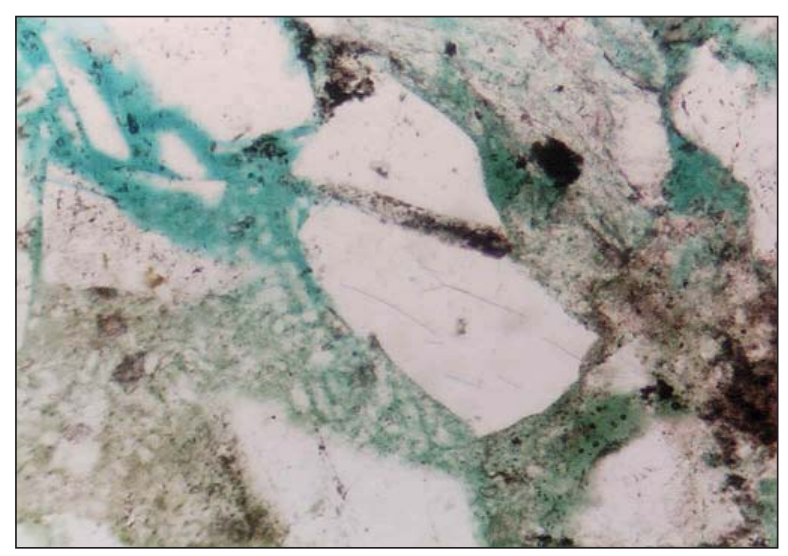

TBUA7_3850c

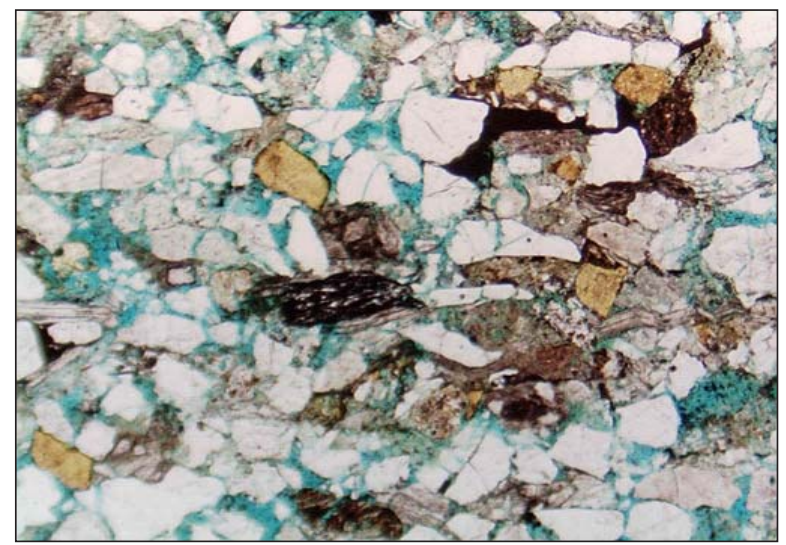

TBUA7_4861b

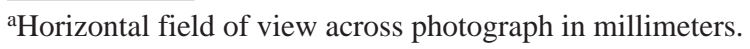


Appendix 1. List of photomicrographs, by well and depth-continued

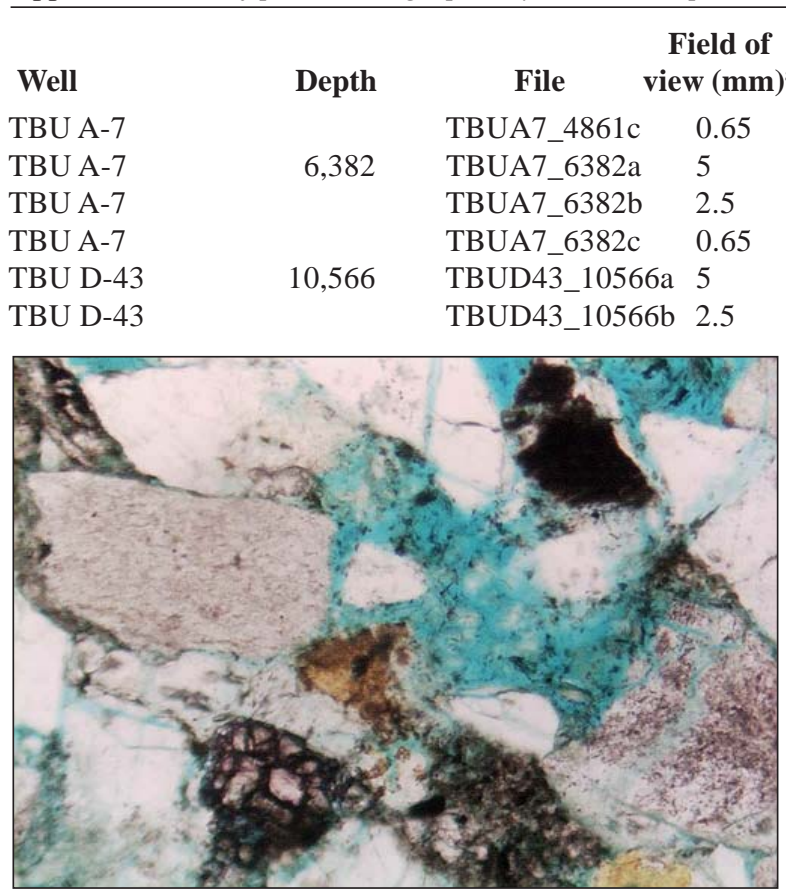

TBUA7_4861c

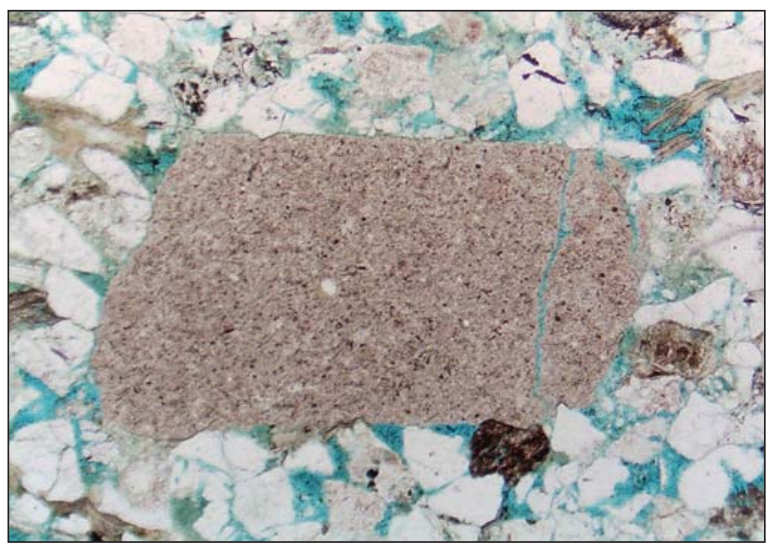

TBUA7_6382b

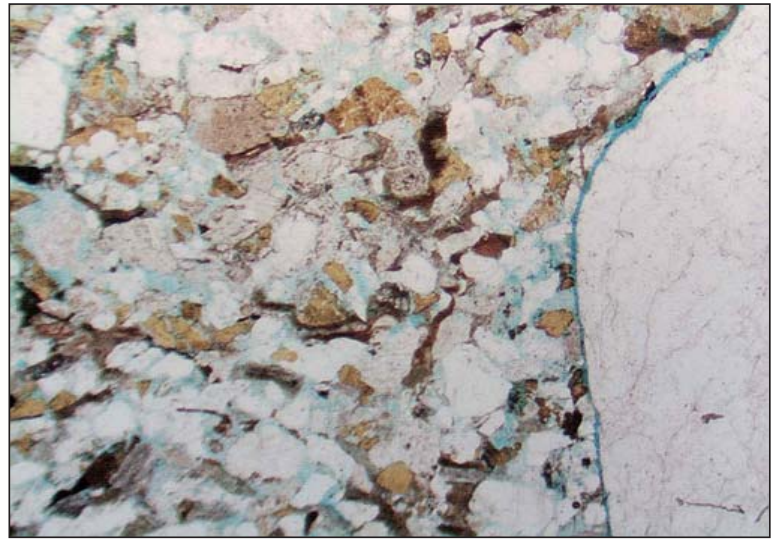

TBUD43_10566a
Notes

Pore-filling kaolinite, epidote

Fresh biotite, strong planar fabric

Outsize chert in porous sandstone

Squashed ductiles, fractured rigid grains

Quartz pebble in micaceous arkose

Squashed micas, silty rip-up

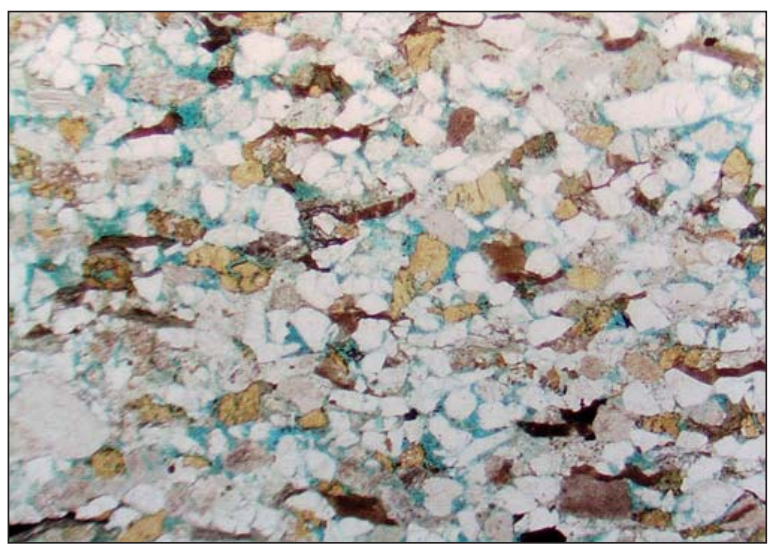

TBUA7_6382a

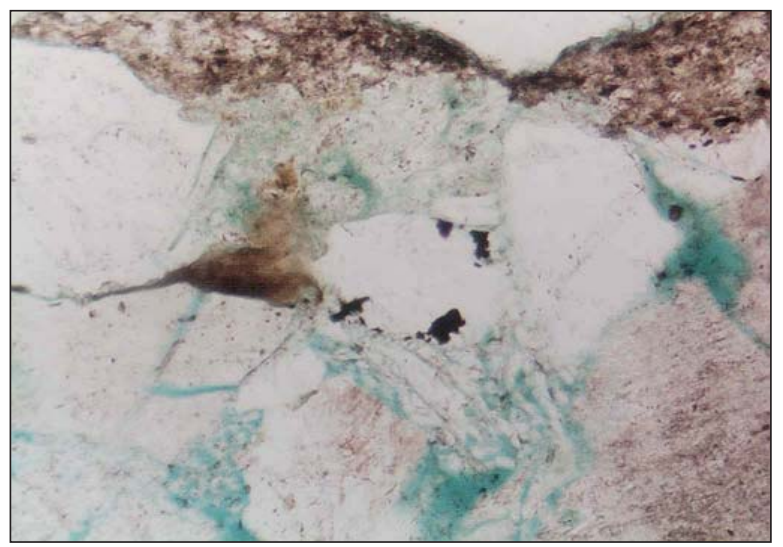

TBUA7_6382c

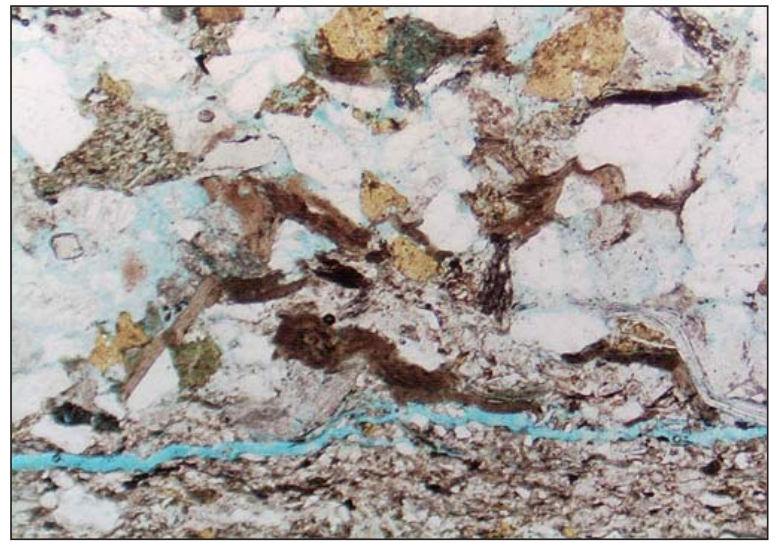

TBUD43_10566b

${ }^{a}$ Horizontal field of view across photograph in millimeters. 
Appendix 1. List of photomicrographs, by well and depth-continued

\begin{tabular}{|c|c|c|c|c|}
\hline Well & Depth & File vi & $\begin{array}{l}\text { Field of } \\
\text { iew }(\mathbf{m m})^{\mathrm{a}}\end{array}$ & Notes \\
\hline TBU D-43 & & TBUD43_10566c & 0.65 & Extensive microcrystalline kaolinite \\
\hline TBU D-43 & 10,795 & TBUD43_10795a & 5 & $\begin{array}{l}\text { Lithic fragments, volcanic, metasedimentary lithic in pebble } \\
\text { conglomerate }\end{array}$ \\
\hline TBU D-43 & & TBUD43_10795b & 2.5 & Granitic gneiss pebble \\
\hline TBU D-43 & & TBUD43_10795c & 0.65 & Chert, detrital chlorite, microporosity \\
\hline TBU G-4 & 9,608 & TBUG4_9̄9608a & 5 & Chert pebble, microstylolitic contact \\
\hline TBU G-4 & & TBUG4_9608b & 2.5 & Microporous vitric tuff pebble \\
\hline
\end{tabular}

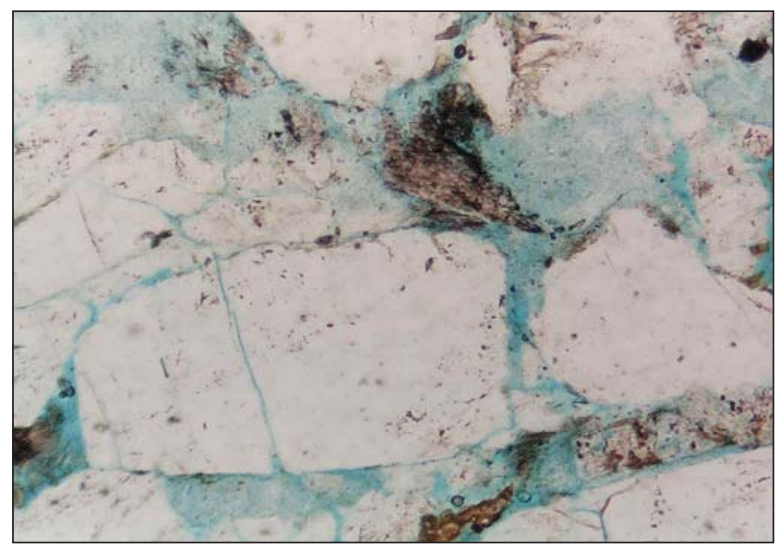

TBUD43_10566c
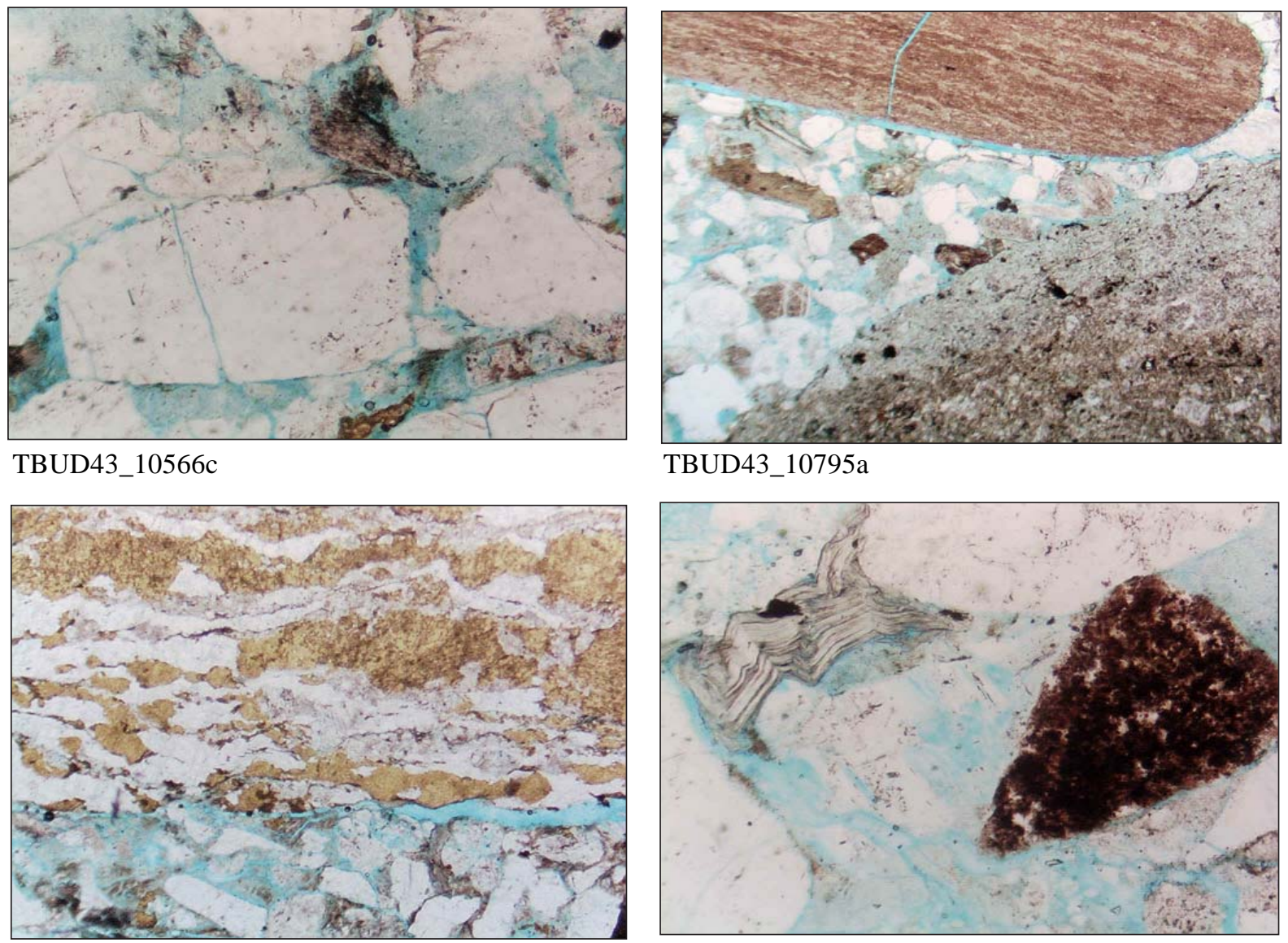

TBUD43_10795a

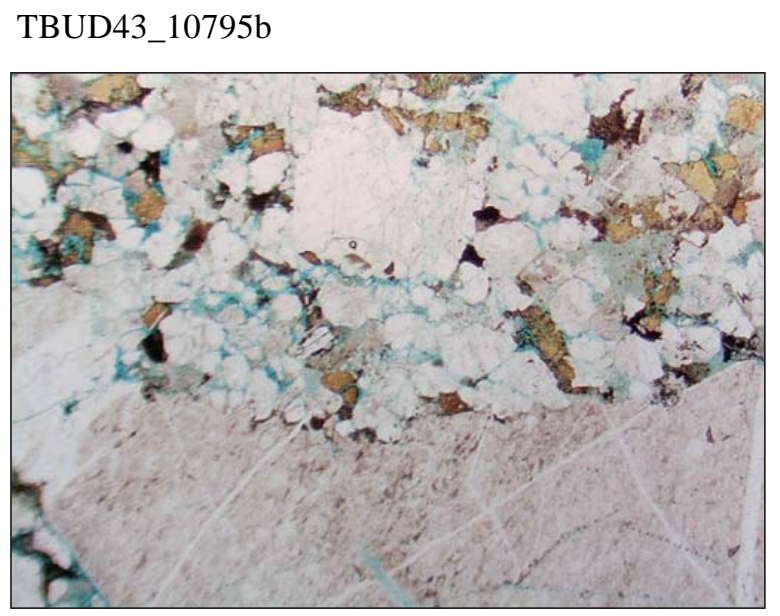

TBUG4_9608a

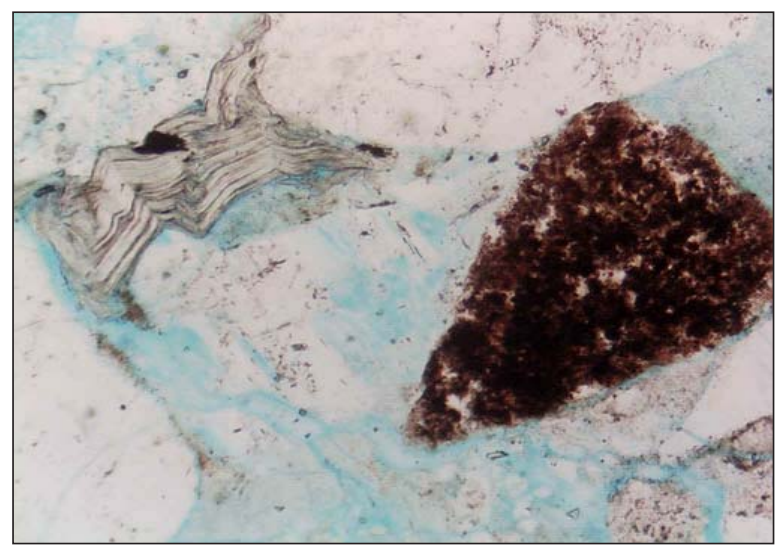

TBUD43_10795c

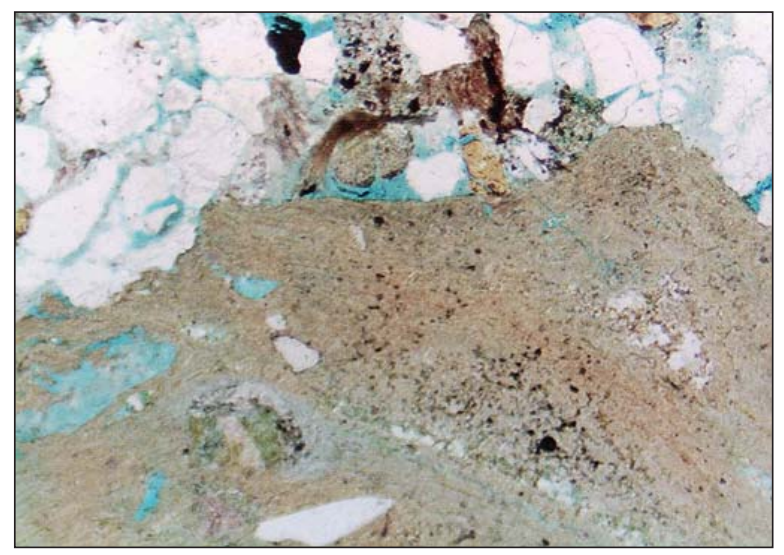

TBUG4_9608b

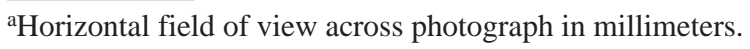


Appendix 1. List of photomicrographs, by well and depth-continued

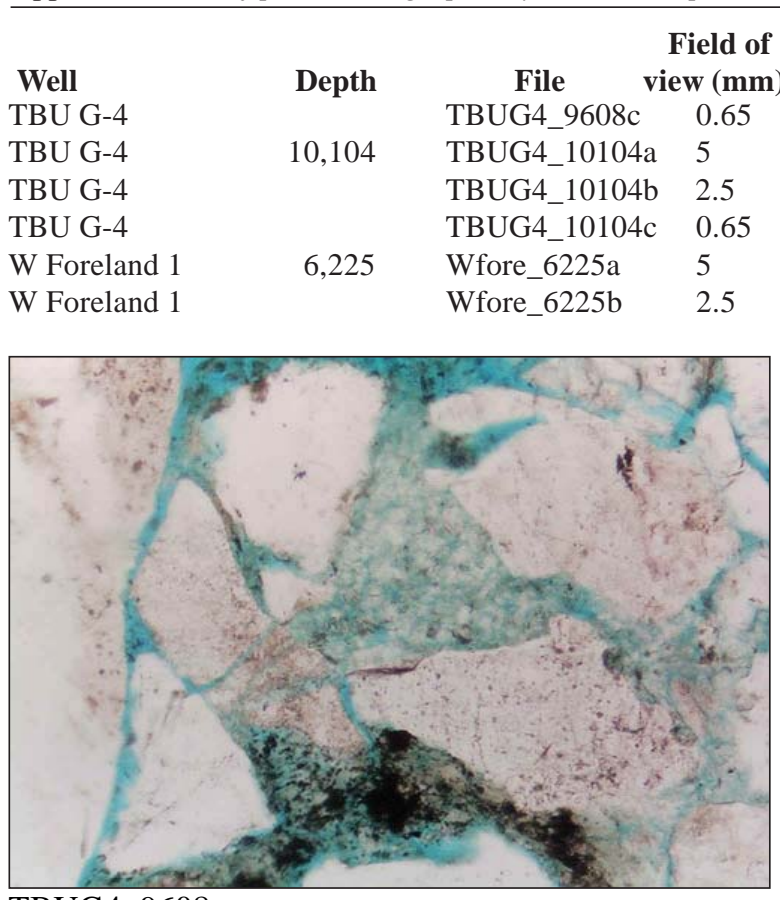

TBUG4_9608c

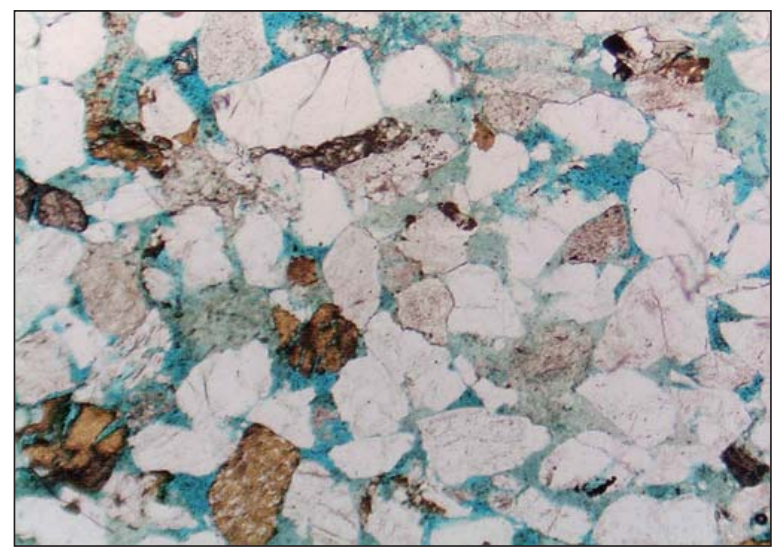

TBUG4_10104b

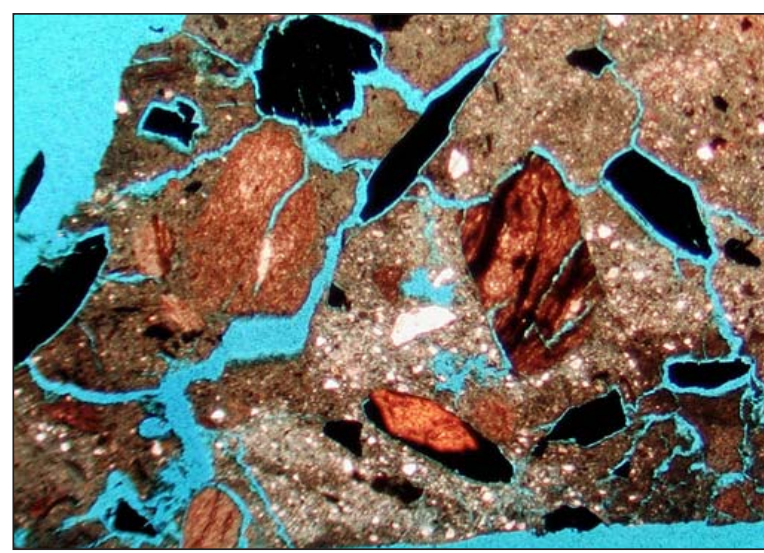

Wfore_6225a

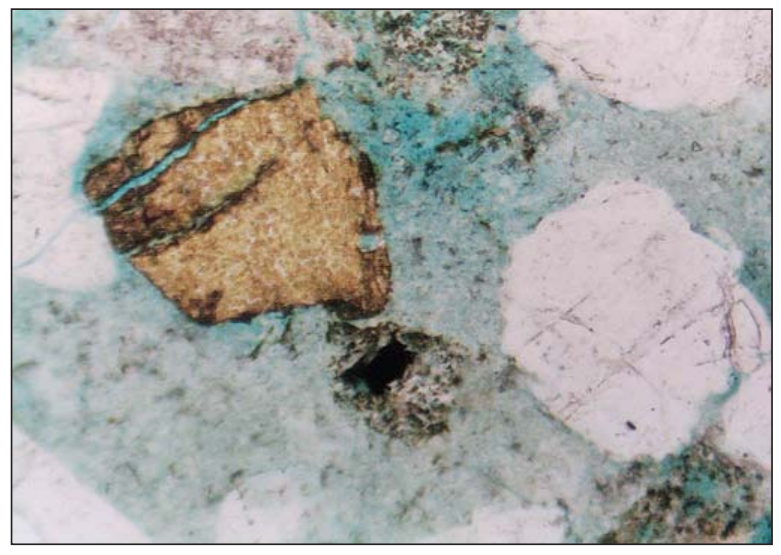

TBUG4_10104c

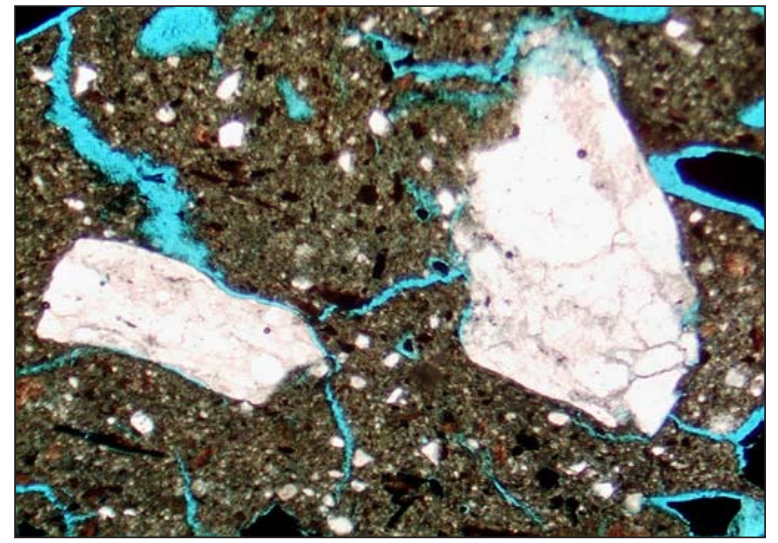

Wfore_6225b

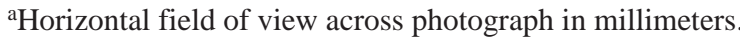


Appendix 1. List of photomicrographs, by well and depth-continued

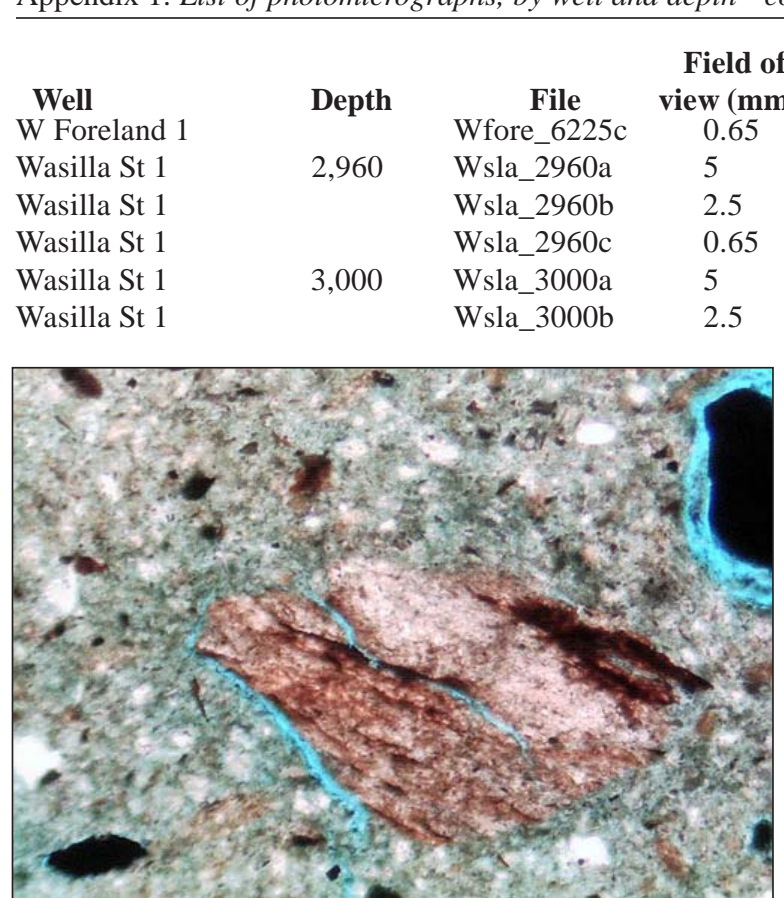

Wfore_6225c

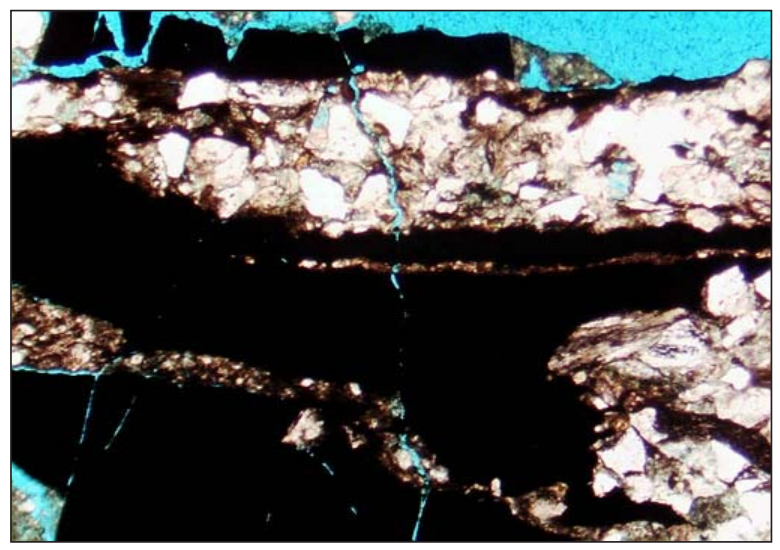

Wsla_2960b

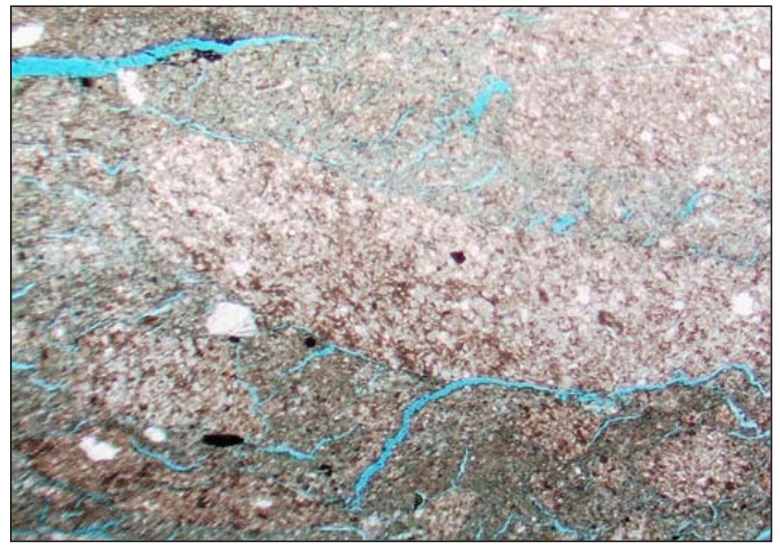

Wsla_3000a
Notes

0.65 Shale fragment in mud matrix

Mixed pebbly mudstone

Fragments of sandstone, coal beds

Silt clast in silty shale matrix

Sandy shale in shale matrix

Calcareous sandstone fragment in shale matrix

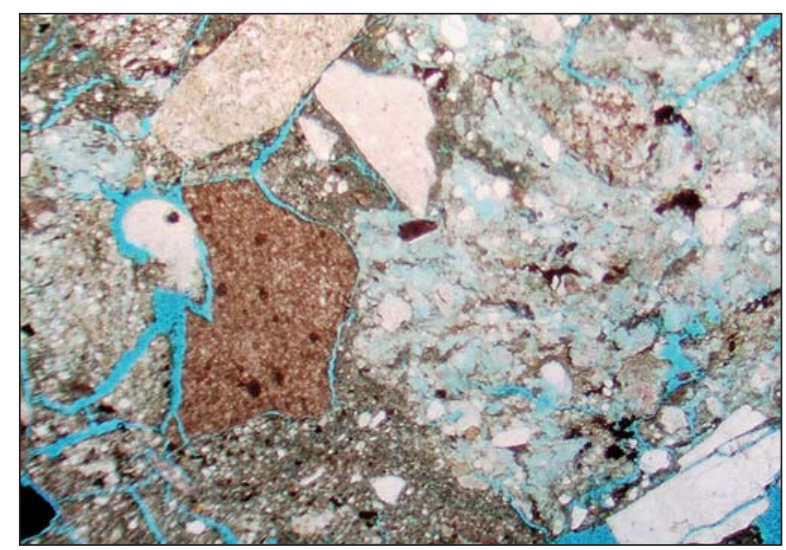

Wsla_2960a

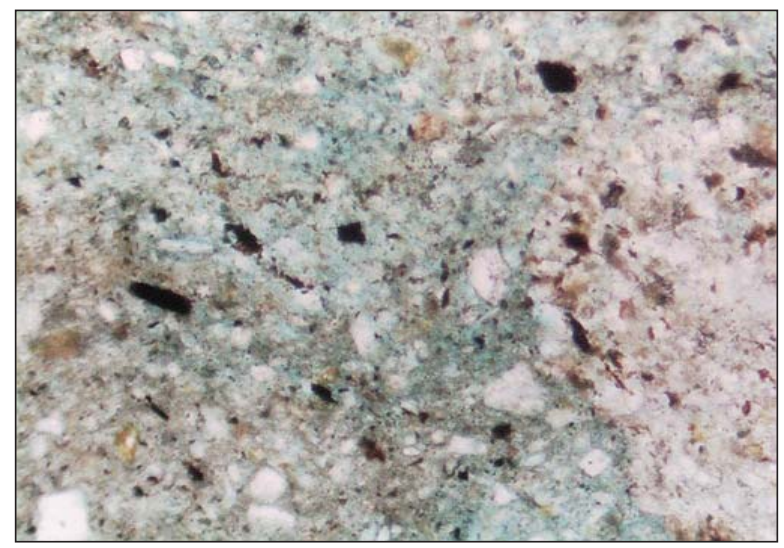

Wsla_2960c

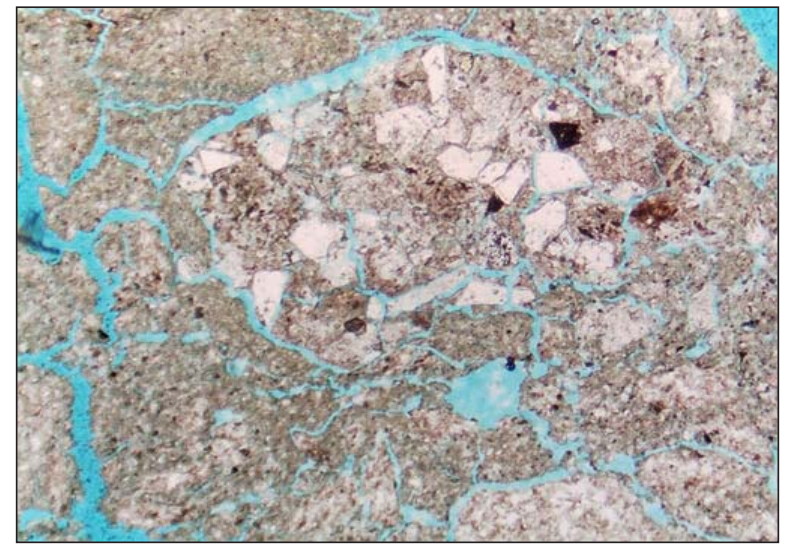

Wsla_3000b

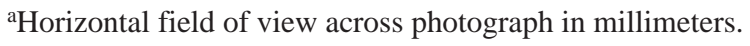


Appendix 1. List of photomicrographs, by well and depth-continued

\begin{tabular}{|c|c|c|c|c|}
\hline Well & Depth & File & $\begin{array}{c}\text { Field of } \\
\text { view }(\mathbf{m m})^{\mathrm{a}}\end{array}$ & Notes \\
\hline Wasilla St 1 & & Wsla_3000c & 0.65 & Shale matrix \\
\hline Wasilla St 1 & 4,140 & Wsla_4140a & 5 & Silica-filled shear vein \\
\hline Wasilla St 1 & & Wsla_4140b & 2.5 & Calcareous crystals in dark matrix \\
\hline Wasilla St 1 & & Wsla_4140c & 0.65 & Calcareous, feldspar, pyrite crystals in matrix \\
\hline Wasilla St 1 & 4,848 & Wsla_4848a & 5 & Barite(?)-pyrite vug-fill in volcanic rock \\
\hline Wasilla St 1 & & Wsla_4848b & 2.5 & Lithic tuff groundmass \\
\hline
\end{tabular}

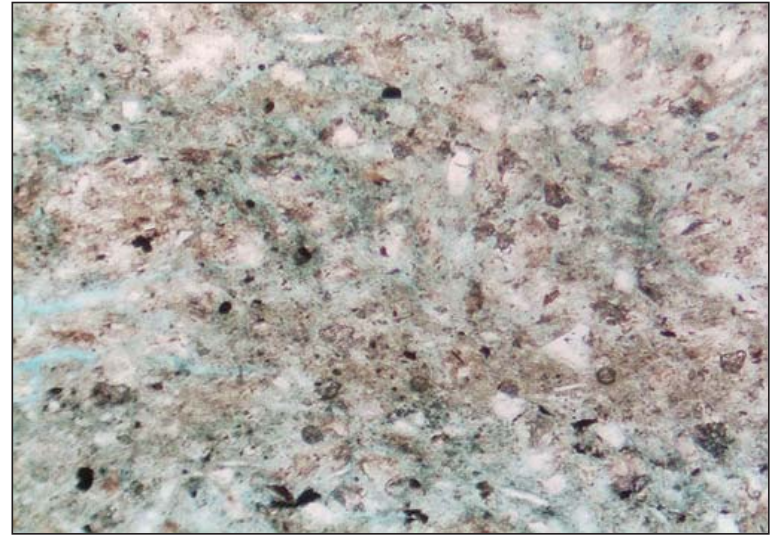

Wsla_3000c

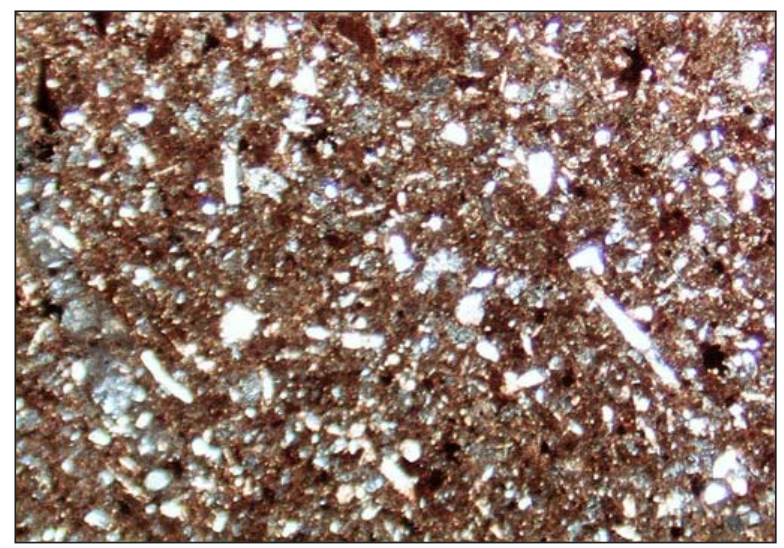

Wsla_4140b

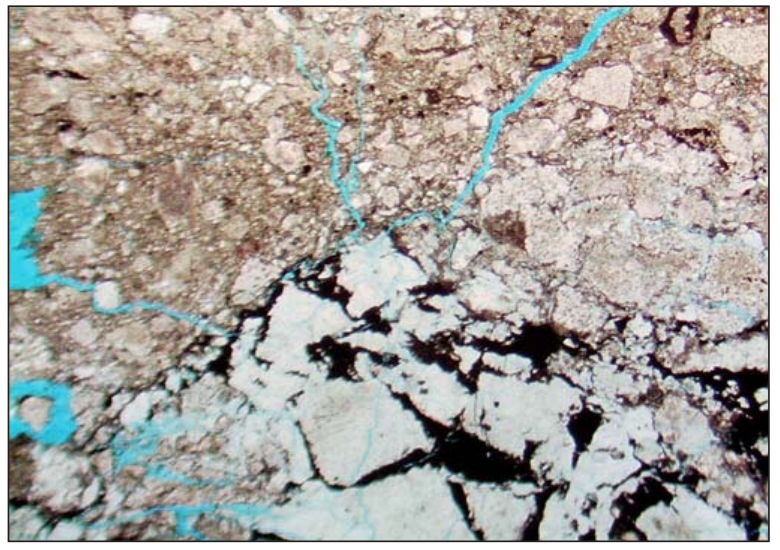

Wsla_4848a

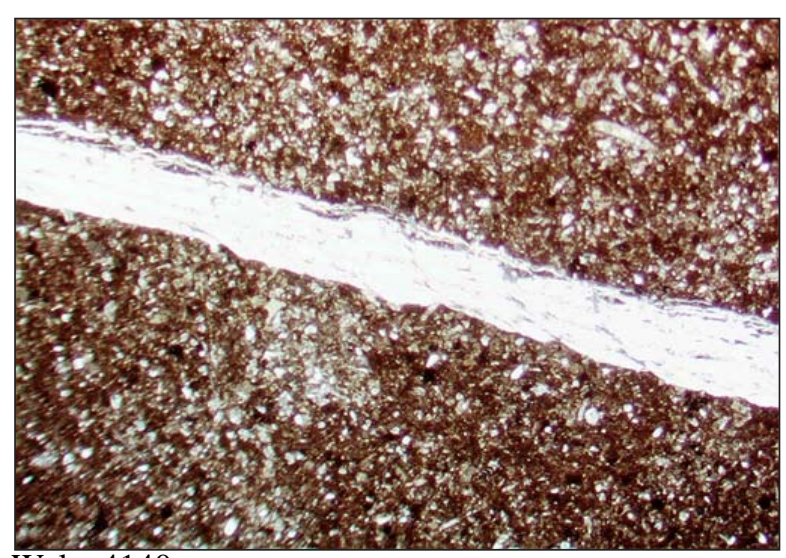

Wsla 4140a

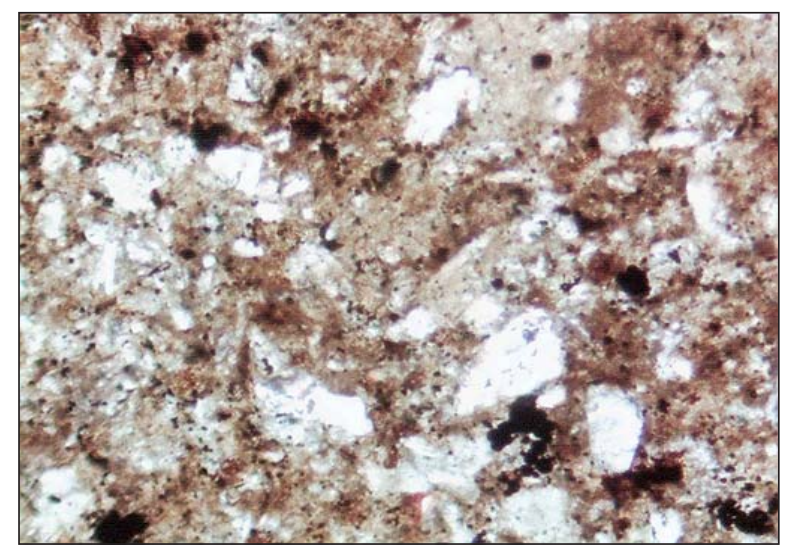

Wsla_4140c

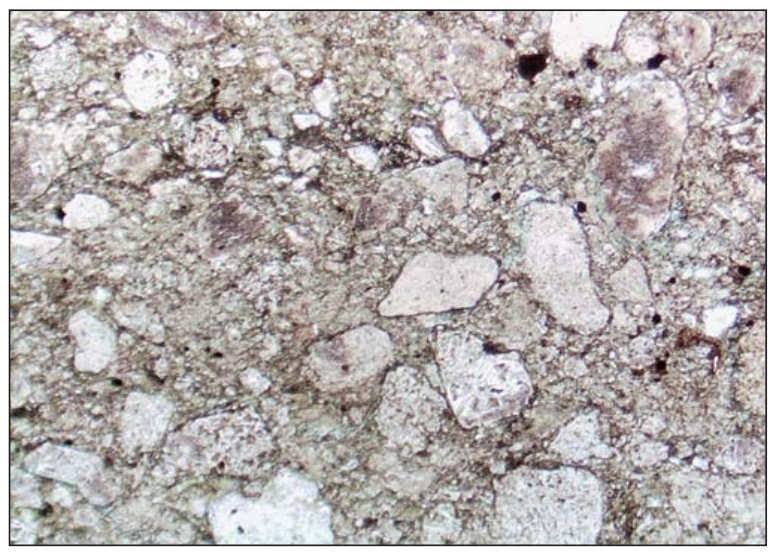

Wsla_4848b

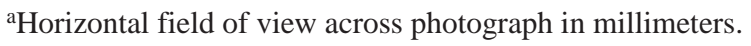


Appendix 1. List of photomicrographs, by well and depth-continued

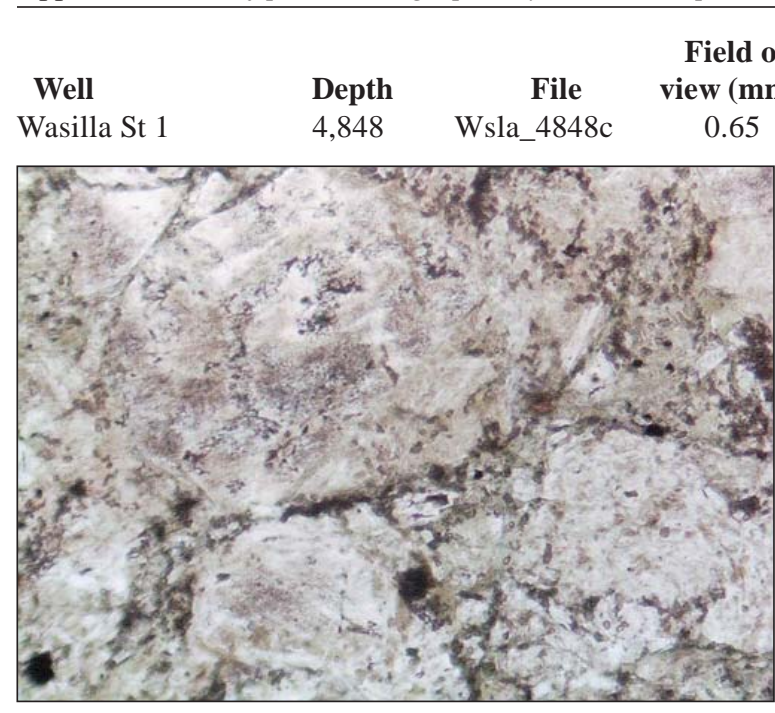

Wsla_4848c

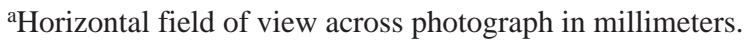

